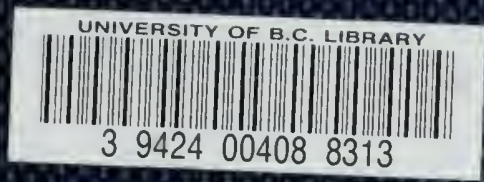

3 IORAGE IIEM

PKUCESSING-UNE 


\section{THE LIBRARY}

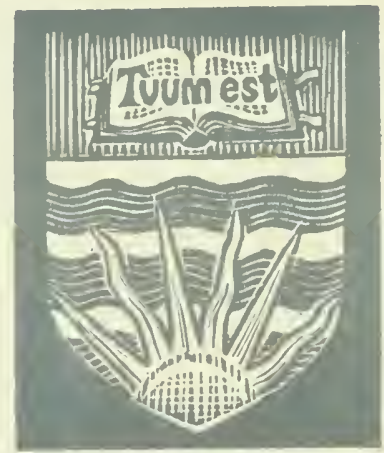

THE UNIVERSITY OF BRITISH COLUMBIA 

Digitized by the Internet Archive in 2010 with funding from University of British Columbia Library 


\section{PUBLICATIONS}

OF THE

\section{STATE HISTORICAL SOCIETY OF WISCONSIN}

JOSEPH SCHAFER, Superintendent 




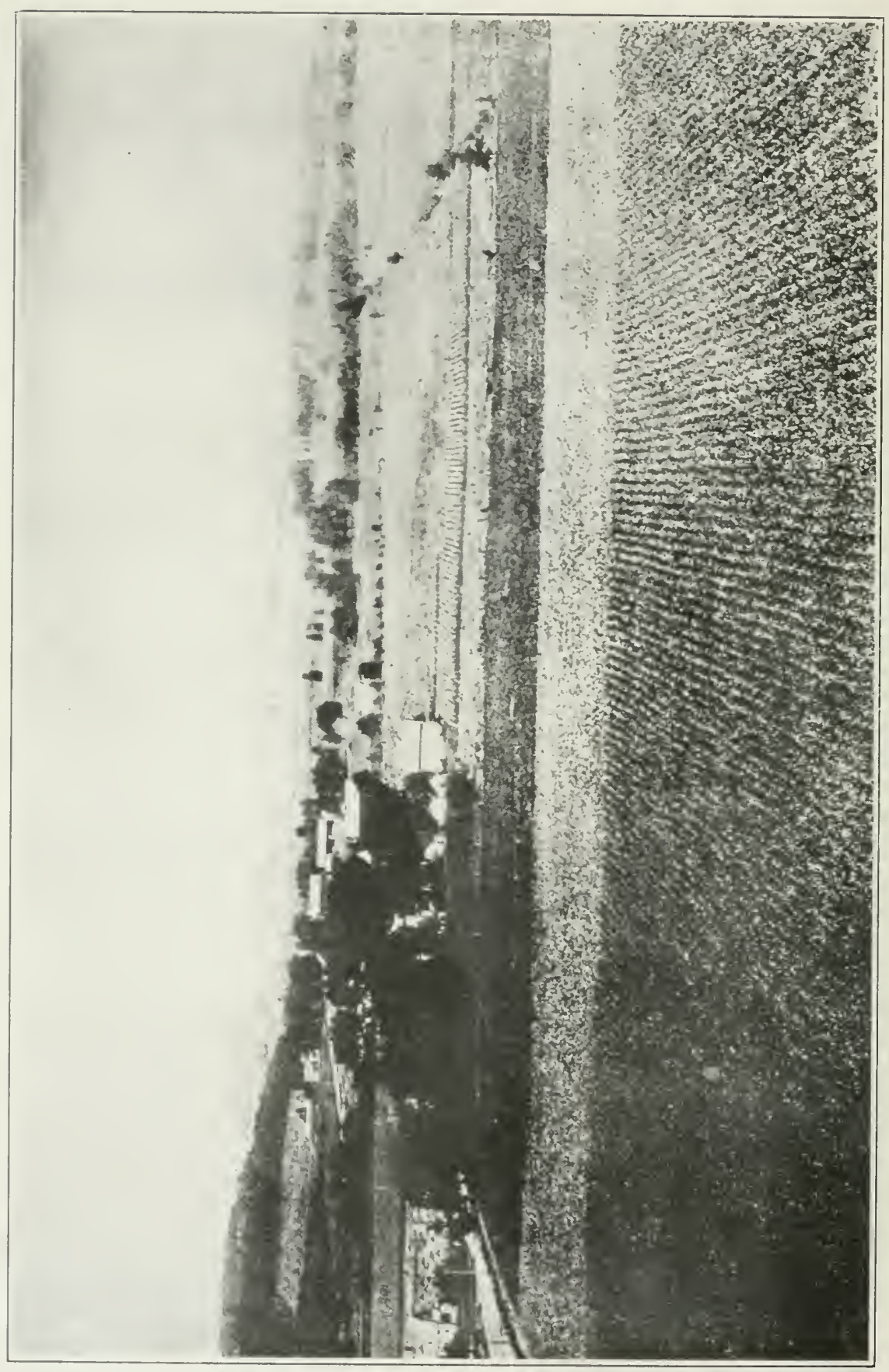

言 
WISCONSIN DOMESDAY BOOK

GENERAL STUDIES VOLUME I

\title{
A HISTORY OF AGRICULTURE IN WISCONSIN
}

\author{
BY \\ JOSEPH SCHAFER
}

\author{
PUBLISHED BY THE \\ STATE HISTORICAL SOCIETY OF WISCONSIN \\ MADISON 1922
}


COPYRIGHT 1922

BY THE

STATE HISTORICAL SOCIETY OF WISCONSIN

1600 OOPIES PRINTED

PAID FOR OUT OF THE INCOME OF THE GEORGE B. BURROWS FUND

HOMESTEAD PRINTING COMPANT, DES MOINES, IOWA 


\section{CONTENTS}

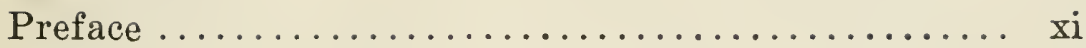

CHAPTYR

I. The Land....................... 1

II. Early Settlements.................. 23

III. Pioneer Origins................... 45

IV. Pioneer Conditions.................. 65

V. Wheat Farming.................. 81

VI. Diversified Farming............... 97

VII. Improved Livestock................ 112

VIII. Lumbering and Farming............. 130

IX. The Agricultural Revolution............ 149

X. Farm Life.................... 165 



\section{L L US T R A T I O N S}

PAGE

Wisconsin-Land Fertile and Fair..........Frontispiece The Elling Eilson Home, Jefferson Prairie; Griffith Richards ........................... 52

Casper Henry Meyer.................... 53

A Prosperous New England Farm............. 58

Old Swiss Church, New Glarus.............. 59

Farm Home at East Winthrop, Maine; Farm Home at

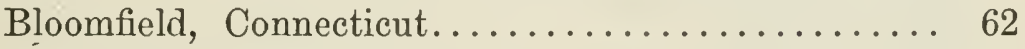

Old Home in Delaware County, New York; A Pennsylvania Farm Home....................... 63

The First Wisconsin Home of John Muir; A Typical Prairie Farm Home, $1850 \ldots \ldots \ldots \ldots \ldots \ldots 66$

Home of William Wilcox on the Lemonweir; First House

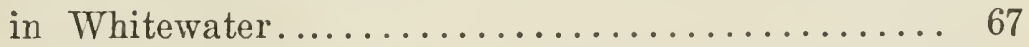

Farm Home of John M. Clark, near Whitewater; Previous Home of John M. Clark. . . . . . . . . . . . . . . 72

A Typical Stone Schoolhouse; Wade's Halfway House, Greenbush, Sheboygan County............. 73

McCormick's Reaping and Mowing Machine, about 1857. 88

Case's Threshing Machine................... 89

Early Pattern of Esterly Harvesting Machine; Old Cradle, or "Cradle-Scythe".............. 92

John F. Appleby's "Knotter"................ 93

Draft Horse Team..................... 98 
An Early Substitute for Wheat on Wisconsin Farms; Shearing Time on a Walworth County Sheep Farm.. 99

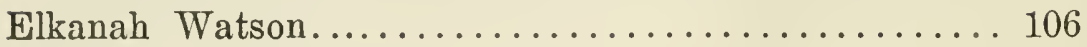
John Wesley Hoyt..................... 107

Paris-Durham, Owned by C. H. Williams; Bloomfield 3d-Devon, Owned by Thomas Reynolds......... 116

Prize Winning Spanish Merinos; Blood Horse-King of Cymry ............................ 117

Young Fremont-French Merino; Prize Winning New York Suffolk Pigs...................... 124

Richard Richards; Thoroughbred Horse-Swigert..... 125 The Pinery............................ 132

A Northern Wisconsin Sawmill; Delivering Hay to the Lumber Camps........................ 133

A Partly Cleared Farm on Cut-over Lands; A Marathon County Farm........................ 142

A Hardwood Forest in Florence County; A New Home in the North........................... 143

William Dempster Hoard; William Aaron Henry...... 150

A Farm "Spring House"'; A Pioneer Household Cheese Press

Hiram Smith Hall, University of Wisconsin; Professor Stephen Moulton Babcock and His Milk Tester..... 160 Receiving Hour at a Wisconsin Creamery.......... 161

A Walworth County Family; Residence of Henry Natesta, Bergen, Rock Prairie................... 168 The Disappearing Rail or Virginia "Worm Fence"; Sausage Grinder Made by a German Immigrant....... 169 The Meyer Farm; Hickory Hill Farm Home of John Muir 174 An Up-to-date Farm and Farm Home, Polk County, Wisconsin .............................. 175 


\section{A P S}

$P_{A G E}$

Map of United States Showing Location of Wisconsin... 2

Geological Map of Wisconsin................ 4

The Driftless Area of Southwestern Wisconsin and Adjacent States..................... 9

Original Areas of Prairie in Southeastern Wisconsin.... 14 Distribution of Prairies in Western Uplands of Wisconsin ........................... 15

Forest Map of Wisconsin............... 16

Swamps of Wisconsin................... 20

The Lead Region...................... 25

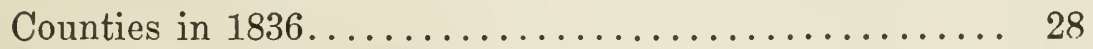

Map of Wisconsin Showing Surveyors' Townships, 1835. 29

Land Entries, Racine County............... 34

Organized Towns, $1848 \ldots \ldots \ldots \ldots \ldots \ldots \ldots \ldots \ldots . \ldots . \ldots 42$

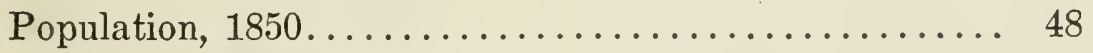

Vermont and New York Canals about 1837......... 60

Lines of Communication, $1844 \ldots \ldots \ldots \ldots \ldots \ldots \ldots \ldots$

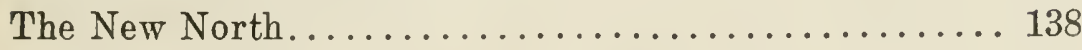





\section{PREFACE}

This volume is intended to serve two purposes. In the first place, it constitutes the general introduction to the Town Studies of the Wisconsin Domesday Book. In the second place, it affords a tentative sketch of the history of agriculture in this state, which it is hoped may prove serviceable until a more complete treatment of that subject shall have been made possible through the intensive local studies which the Domesday Book plan calls for.

The work on Wisconsin rural towns (townships, many call them, but town is the technical designation), which has been in progress for about two years, had reached the stage where the data relating to twenty-five towns were ready to be cast in final form for publication. Then it was seen that the matter on each town could be treated in much smaller compass, and the whole series consequently published much more economically, if there was a comprehensive sketch of the history of agriculture in the state to which on all general topics one could simply refer, instead of repeating such matter in the texts pertaining to the separate towns. With such a sketch to serve as introduction, the texts of the town studies can be shortened about one-half-no insignificant item when we consider the cost of paper and of printing. Accordingly, I proceeded to write the sketch here presented, and found, as had been anticipated, that the data collected for the intensive local studies, although still limited in scope, were of unique service in this wider investigation. A volume of those town studies, twenty-five towns widely distributed geographically, including plats representing farms and farmers of 1860 , is now in press and will be issued by the State Historical Society in the near future. Its publication will afford an opportunity of determining the various ways in which such a microscopic 
historical survey of local areas may help to advance the cause of history.

The history of agriculture in Wisconsin is believed to possess so much inherent interest to Wisconsin people, that the publication of this sketch as a separate volume, of moderate size, is fully justified. To the full extent of the present edition, it is thus made immediately available for the use of libraries, farmers' clubs, schools, and individuals in both public and private stations.

I desire to make emphatic my description of the present volume as a sketch of the history of agriculture. No claim of finality in the study of that subject is made, and I am well aware that the rigorous exclusion of many sub-topics which others would have stressed in writing a similar work would subject this book to criticism, were its claims less modest. I had in mind to write down, in minimum space, just those things which would be most useful in connection with the local studies for which the book is the background. A number of topics, like lumbering, railway building, mining, manufacturing, commerce, and labor, have been treated with relative completeness by Frederick Merk in connection with his admirable study of the Economic History of Wisconsin during the Civil War Period, which was published by this Society as Studies, Volume I. For the present, and until more complete studies of the same topics for the entire period of Wisconsin's history can be undertaken, those portions of Merk's book which deal with them will serve the highly useful purpose, in conjunction with this history of agriculture, of underpropping the Town Studies. Other topics, as for example agricultural education, agricultural organization, agricultural finance, call for such extended special investigations that for practical reasons their treatment had to be deferred to a later time.

The bequest by the late Senator George B. Burrows of the major part of his estate to the State Historical Society, which has power to employ the income thereof for purposes of this nature, enables the Society to publish the present volume and xii 
also to begin the publication of the series of volumes contemplated under the title of Town Studies. The Town Studies, since the various processes involved in their preparation are now fully worked out, can hereafter, it is hoped, appear at the rate of several volumes per year. General studies, analogous to the history of agriculture, will also appear from time to time.

I wish to acknowledge the assistance rendered me, in connection with the preparation of this work, by Edna Louise Jacobson, the Superintendent's secretary, who performed valuable research and compilation work on phases of the study and put the manuscript in shape for the press; to Mary Stuart Foster, of the Library staff, who prepared the maps; and especially to Dr. Louise Phelps Kellogg, senior research associate, whose careful reading of the entire manuscript has added materially to the value of the book.

JOSEPH SCHAFER.

State Historical Society of Wisconsin

November, 1922 



\section{CHAPTER I}

\section{THE LAND}

The imposing geographic arch formed by the Mississippi lands on the one hand and those of the Great Lakes and the St. Lawrence basin on the other has for its keystone the territory embraced within the boundaries of Wisconsin. Resting lightly on Lake Superior but with a long shore line on both Lake Michigan and the Father of Waters, that territory also holds the most convenient line of communication between the two systems, the Fox and Wisconsin rivers, separated by a single short portage. This explains why so much of the early history of the state not only connects but mingles and blends with the French history of Canada and Louisiana, while its Indian lore holds in one all-embracing story the traditions of the Winnebago, the Six Nations, the Hurons, the Menominee, Potawatomi, Sauk, Foxes, Chippewa, and the Sioux.

Wisconsin, on the small-scale physiographic map of the United States here reproduced (Fig. 1), seems alınost featureless so far as surface is concerned. A little less than one-half its total area, the northern and northwestern portions particularly, is shown to have an altitude of between 1000 and 2000 feet, while the southern and eastern portions lie at an elevation of less than 1000 feet. A few small tracts in each of these divisions vary from the mass. There is no land in the state that rises above the 2000 -foot limit or falls below that of 500 feet.

From such indications one might infer that the land of Wisconsin is a vast, uniform plain-land like that of Illinois to the south or of Iowa to the west. But a closer examination of surface characteristics shows this to be an error. Wisconsin has a topography which, within the elevation limits specified, is very attractively diversified. This is brought out in a meas- 
ure by the large-scale relief map of the state (see pocket map). It represents along the Mississippi a belt of unequal width, narrower at the north and broader at the south, which is much divided and dissected by eroding streams-a genuinely "hilly" land. In the middle and northern portions are isolated ranges, ridges, and hills which stand out conspicuously -like Penokee Range, Flambeau Ridge, Barron Hills, Rib Hill, and McCaslin Mountain-with innumerable inequalities

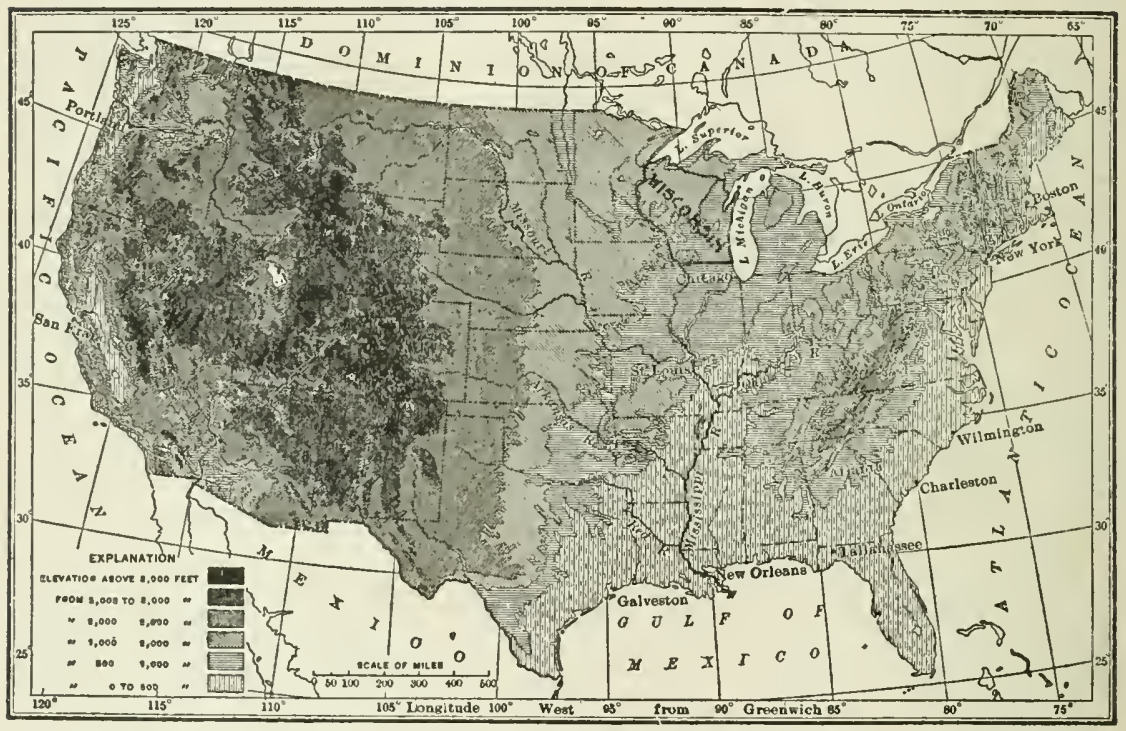

FIG. 1. MAP OF THE UNITED STATES SHOWING THE LOCATION OF WISCONSIN

Courtesy of Wisconsin Geological Survey

not distinguished by special names. Even the southeast portion of the state, the plain-land par excellence, has only restricted areas where the surface is flat. For the most part it is rolling and uneven, with well defined depressions controlling the flow of the water courses in addition to numerous lakes, ponds, and marshes. The lakes of northern and northwestern Wisconsin, also, are an impressive feature of the topography. 
'There is but one large area which from the map one rightly judges to be flat. It lies on both sides of Wisconsin River nearly in the form of an equilateral triangle, with one angle on the river near Kilbourn, another on the boundary of the Driftless Area east of Stevens Point, and the third about the same distance east of Black River Falls. This region embraces most of Adams and Juneau counties, with smaller portions of Wood, Portage, Jackson, and Monroe, and a wedgeshaped slice of Waushara. Yet, even within that generally undiversified region occur the castellated rocks near Camp Douglas, Necedah Hill, and other interesting features of surface relief.

If, with the geologist, we penetrate beneath the mantle of soil to bedrock, which is the foundation of the land, we find underlying Wisconsin a series of varying rock formations. The principal ones of these have been described as crystalline (or Archean) rocks, upper Cambrian (Potsdam) sandstone, and limestone (the last-named of several distinct kinds). The accompanying map (Fig. 2) shows the state divided geologically into three main provinces determined by the prevailing character of the foundation rock, as follows: First, occupying nearly the whole northern part and extending down somewhat below the latitude of Green Bay, especially in Waupaca, Wood, and Portage counties, is the region of crystalline rocks; second, sweeping around this on the south, west, and east, and extending south well below the great westward bend of the Wisconsin, also along the river valley, is the region in which the bedrock is upper Cambrian sandstone; third, the portions of the map shaded deeper, namely, the whole of the eastern part of the state, the southern part, and areas along the Mississippi separated by stretches of upper Cambrian, represent the limestone sections of the state.

The three kinds of limestone are represented by three distinct ways of parallel-lining (or hatching) the map. Where the lines are drawn northwest and southeast the rock immediately below the soil is the Niagara limestone. This lies on 


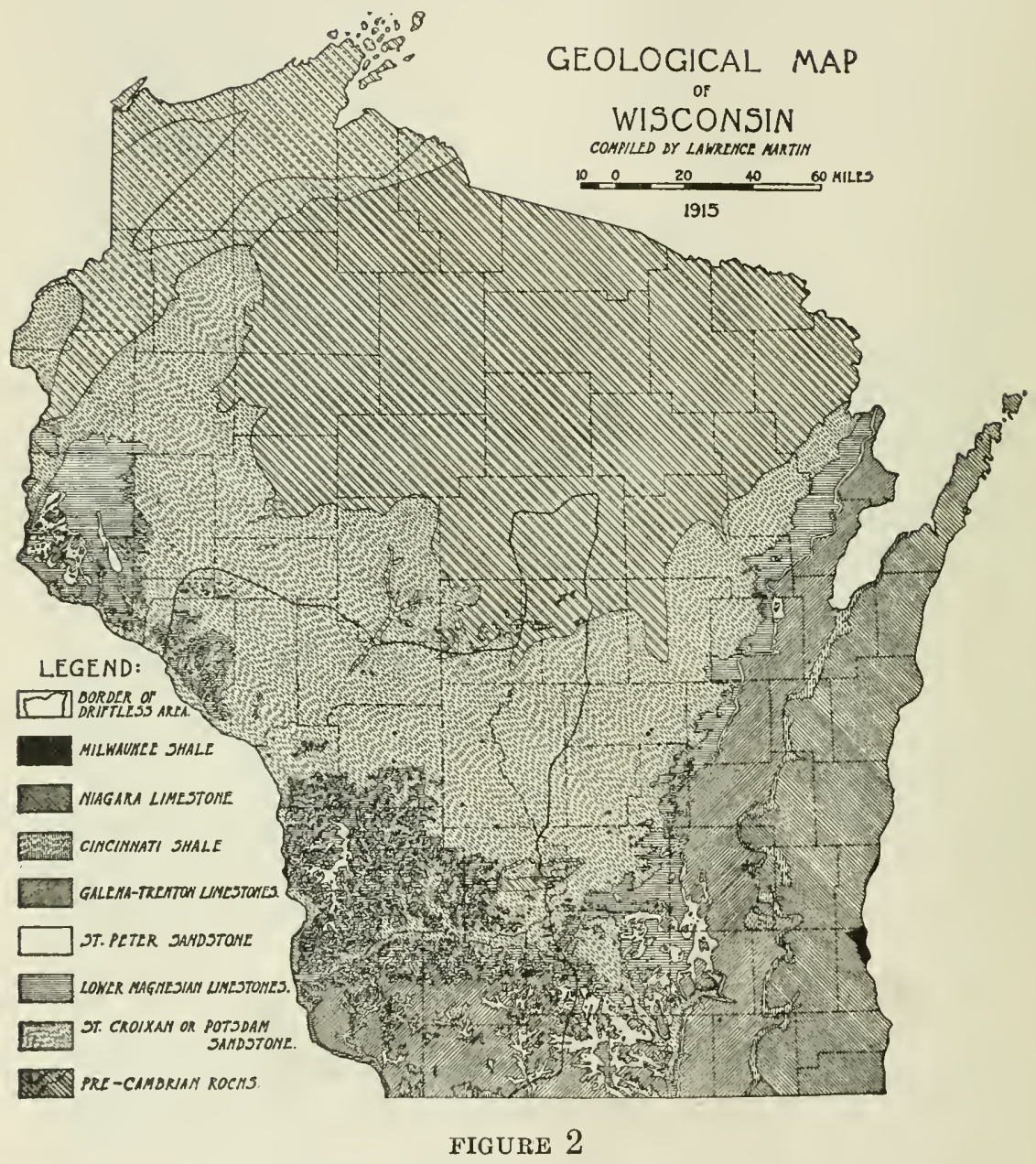

Courtesy of Wisconsin Geological Survey 
top of other formations from the lake to the ridge escarpment shown as running from the south line of the state to Green Bay and along the southeast shore of the bay. From that line westward the Niagara has been removed by erosion, and so we come to the next lower distinct limestone formation, which is called the Galena-Blackriver (Galena-Trenton) and is represented by lines drawn northeast and southwest. A still lower deposit of limestone appears under the soil wherever both the Niagara and the Galena-Blackriver have been worn away. This is called lower magnesian limestone. The symbol for this formation is the horizontal ruling. It is seen as a narrow belt running on the south side of Wisconsin River from its mouth to the great bend, and northeastward to the Michigan boundary, with islands and headlands of the same formation in the south central counties and several large but interrupted masses north of Wisconsin River. The most prominent single mass of lower magnesian is the one which underlies the counties of Pierce and St. Croix. Both north and south of the Wisconsin the lower magnesian is in many places, especially along the streams, worn through so that the upper Cambrian sandstone, which underlies it in turn, appears as the bedrock. The blotches of white shown on the map represent the St. Peter sandstone, which is a thin layer usually found lying between the Galena-Blackriver and the lower magnesian. The St. Peter is soft, and in most places where its protecting cover of Galena has been removed it has also been eroded away. But occasionally it remains as the formation just beneath the soil over considerable areas, as in parts of Rock, Green, Jefferson, and Dodge counties in the east, also in Vernon near Wisconsin River, and in Pierce and St. Croix in the north.

All of these rock formations except the crystalline are regularly stratified, suggesting that they are the results of submarine activity in rock building. The limestones, it is supposed, were made by a process of consolidation from the ooze which forms on the sea-floor and which often includes a vast 
amount of calcareous material derived from the shells of sea animals. In the area of crystalline rocks are found intruded masses of volcanic origin which perhaps formed the basis of one-time mountains, now eroded down until the area is nearly a plain-what is called by geographers, a peneplain.

One of the main forces which affected the Wisconsin region in recent geologic times, tending to even the surface, to fill the valleys and plane down the ridges, incidentally forming lakes and marshes, changing the courses of streams, etc., was the great continental glacier. It moved over the whole state (except one section to be described later), retreated, advanced, retreated and advanced yet again, before it was finally forced, by the moderating climate, to retire into the far north. When the glacier had done its work, the surface of Wisconsin was approximately as we know it today. Vegetation came forward as the climate grew milder, and conditions gradually became suitable for animal and human life.

For preparing Wisconsin to be the abode of a great civilization the glacial action was significant in several ways. It tended to "iron out" the rougher, hilly surfaces; it made the flat lands more rolling by creating elevations of glacier-borne materials upon them; it made soil and distributed it over vast areas. As the glacier moved athwart the ridges it acted like a colossal earth planer, carrying with it their rounded tops, dirt, loose rocks, and rock strata often to the depth of many feet, depositing part of this material in adjacent depressions and carrying the rest farther. ${ }^{1}$ The result was a rolling terrain where formerly were high hills and deep valleys. In that manner much of what otherwise must have been waste land, because of being too steep and rugged for cultivation, was modified by the glacier into cultivable surface. Admirable examples of this process are available in southwestern Wisconsin where the Driftless Area, which was never

${ }^{1}$ There is limestone, as we have seen, both in the glaciated and in the unglaciated lands. But limestone caves occur only in the unglaciated, running down into the rock formation often many feet. It is believed that the glacier, wherever it passed, disturbed the rock formation inefly enough to crode the cave-bearing upper portions. 
invaded by the ice sheet, joins the drift or glaciated region. The proportion of waste land in the Driftless Area is much higher on the average than in the drift. This is true notwithstanding that the glacier, in one way, created waste land by making lakes, ponds, and marshes through the uneven grading of valleys or by scooping and gouging out rock masses. It has been said that the glacier must be held responsible for most of the 2,500,000 acres of marsh land in Wisconsin. ${ }^{2}$

For the purpose of agriculture it was almost as fortunate that the flat lands were made more uneven as that the rough lands were made more smooth. A gently rolling surface affords natural drainage, for the want of which much flat land becomes waste in unfavorable seasons. Besides, the glacial hills and hillocks-the moraines, drumlins, kames, and eskers (to borrow the geologist's terms) - diversify the surface, vary the tree growth, and account for much of the natural beauty for which Wisconsin is so justly famed.

The soil, which in most places covers the bedrock, is called residual when it has been made "on the spot" out of the native rock by the process of weathering. It becomes alluvial when produced by stream deposition; and when laid down, in fine particles, by the wind it is called loess. The above are the principal soils, classified according to derivation, which are found in unglaciated (driftless) regions. But wherever the glacier has passed over a given surface its single agency in producing and distributing soil has usually been superior to all others, and the soil of the region is called glacial, or drift, soil. These terms do not mean that the glacier necessarily made all there is of the soil, for the process of weathering and the other processes have been going forward and producing results both before and since glacial times. But the glacier has affected the soil wherever it passed. In the first place, it carried with it, often for hundreds of miles, some of the soil

2 Much of that land, however, need not remain waste. A part of it could be drained by individual farmers whose farms embrace small tracts of it, and sometimes extensive tracts could be drained by the coöperative method, under a law for creating drainage districts. When drained and properly subdued hy cultivation, most of the marsh lands become exceptionally productive. 
material which it spread over Wisconsin rock formations. Secondly, it ground up much native rock and spread it over the surface in the vicinity. And in the third place, it mingled together materials from various sources before they were finally deposited where they could grow the crops of our own day.

It has been estimated that seventy-five to eighty per cent of the soil in most glaciated localities in Wisconsin was derived from materials of the neighborhood. The rest may have been carried great distances. No doubt Wisconsin has much soil which originated in the Canadian provinces. Certainly many of the bowlders which were carried in the glacier and dropped here and there as drift over the whole glaciated area are properly assigned to the rock formations of a far northern latitude.

Sometimes the twenty or twenty-five per cent of soil derived from a distance becomes an exceedingly important element, as in a region which is underlain by a sandstone formation the soil of which is too light, porous, and deficient in plant food to possess high fertility. Thus the mixing of material derived from the crystalline rocks and from the limestones with the soil native to the great upper Cambrian region in middle Wisconsin rescued a large share of that region from comparative poverty. The largest continuous body of light sandy soil in Wisconsin is in the flat triangle described above, which begins near Kilbourn on the river and extends northeast and northwest to the neighborhoods of Stevens Point and Black River Falls. But that is precisely the portion of the upper Cambrian region which received no glacial drift and, except immediately along the trench of Wisconsin River, no river drift or alluvium either. Its soil is weathered sandstone. To the east of the triangle are several counties whose bedrock is the same, but having been visited by the glacier and generously treated to a portion of its load of silt brought from the north and east, their soil, while still light, is much more fertile. Besides, the glacial hillocks diversify their surfaces. To the 
west of the triangle is a territory of considerable size, resting on the upper Cambrian formation, to whose lower valleys farflowing rivers have carried silt from the north, which mingling with the sand makes a productive soil. What sand was carried down from the middle region over the limestone farther south served generally, by mixing with the stiff clay of that region, to improve its soil there.

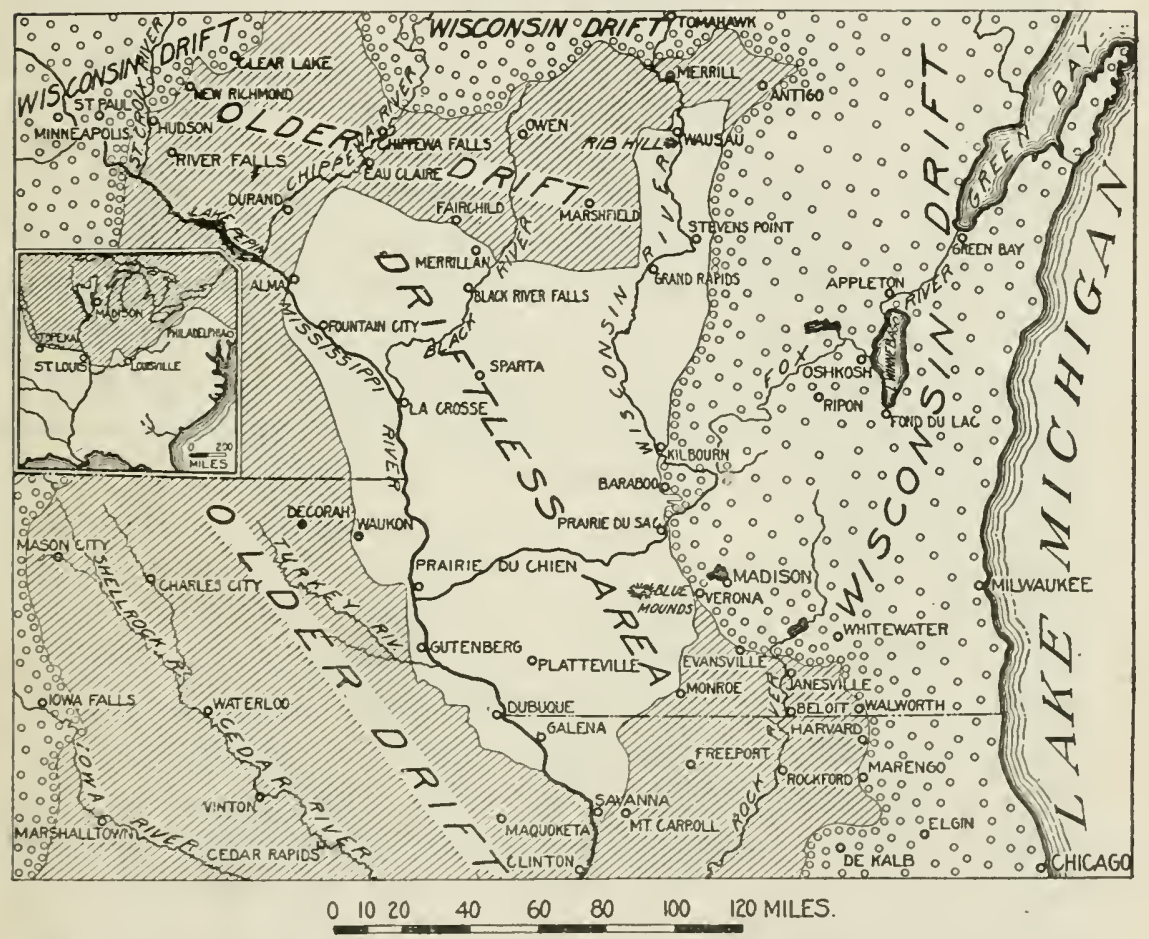

FIG. 3. THE DRIFTLESS AREA OF SOUTHWESTERN WISCONSIN AND ADJACENT STATES

Courtesy of Wisconsin Geological Survey

As already stated, there is one large section of western Wisconsin which (with adjacent portions of Illinois, Minnesota, and Iowa) was unvisited by the glacial ice sheet-the Driftless Area. This region is in character like parts of the 
South to which the glacier did not reach, but as a northern land it is unique from the fact that it forms an island of unglaciated land in a vast sea of glaciated. The continental glacier, geologists have decided, split somewhere in the northwestern part of the state, one lobe driving for a time southwestward and the other southeastward, thus missing the area in question. At one or more periods other forces finally brought the two lobes together again. This behavior on the glacier's part was so striking as to make Wisconsin's driftless area a subject of interest to geologists the world over. The map (Fig. 3) will show the relation of that area to the rest of the state, also to the neighbor states. Its surface is estimated to include 15,000 square miles (about the size of Denmark), of which 13,360 are in Wisconsin. It is wider in the north and narrower in the south. The Wisconsin counties of Grant, Lafayette, Iowa, Crawford, Richland, La Crosse, Monroe, Juneau, Jackson, Vernon, and Trempealeau lie within the Driftless Area, while Green, Dane, Sauk, Portage, Wood, Marathon, Buffalo, and Eau Claire are partly driftless and partly glaciated.

By comparing the last map with Fig. 2, it is seen that the Driftless Area embraces a large territory underlain by the Galena-Blackriver limestone in the southwestern counties, while north of Wisconsin River the formations beneath the surface are the lower magnesian limestone, the upper Cambrian, and the crystalline, with some patches of St. Peter sandstone. The character of the country has been influenced the more by these rock formations because they do not lie quite horizontally but rise gradually toward the west and the north (though again sinking somewhat toward the Mississippi), making a large portion of the Driftless Area an upland. Its elevation varies from 1280 to 900 feet, while the lands nearer Lake Michigan are about 700 feet above sea level and those in central Wisconsin still lower. The larger rivers, especially the Mississippi and the Wisconsin, have eroded deep trenches, cutting through the limestone formation and well 
down into the upper Cambrian sandstone. The ridges along the Mississippi sometimes attain a height of 500 feet, which is one measure of its cutting, while the hills on both sides of the Wisconsin in its lower reaches are nearly as high.

Because of these deep river trenches, the smaller streams flowing into the Wisconsin and the Mississippi from the western upland have likewise dissected the land deeply. Wherever these streams flow parallel to one another and near together the upland is much cut up and the bluffs are rounded. Sometimes the latter are worn down to the hog-back form, or even reduced to mere flattened watersheds. But mostly the streams have eroded deep valleys, the lower courses of which are partly filled with alluvium brought from higher up, and the bluffs vary in elevation from about 400 feet near the streams' junction with the great rivers to a few feet at their head-springs. The soil in these valleys, for the most part, is of limestone origin, though sand from the upper Cambrian formation, often cut into by the streams, is mingled therewith. The tops of the ridges are covered with weathered limestone, save where this has eroded away to the limestone bedrock. In places outcrops of St. Peter sandstone are left on the highlands.

There are no lakes in the Driftless Area and very few marshes, the drainage almost everywhere being complete. Creeks, rivulets, and rills uniting with each other and joining the main stream make a very perfect tree-like (dendritic) river system. In the older, lower portions of the valleys the streams flow sluggishly through the alluvial deposits of silt, while in their upper courses they are always swifter and sometimes have the character of mountain torrents. There they still are cutting trenches in the limestone or St. Peter sandstone, while every freshet carries down and distributes over the lowland a quantity of fine silt abstracted from the upland clays.

The steep sides of the biufifs in the Driftless Area usually appear, from a distance, to be parallel-lined by the exposure of rock strata. Sometimes, when more rounded, they are cov- 
ered thinly with soil and grow grass and trees successfully. The tops vary in character from the useless hog-back to fine, spacious levels capable of being cultivated and made into excellent fields. In some portions these are called ridge fields. ${ }^{3}$ They are reached by steep ridge roads built along the sides of the ravines from the lowlands.

That portion of the Driftless Area which lies south of the Wisconsin is sometimes said to be divided by the "Military Ridge." It is more exact to say that the streams flowing north to the Wisconsin have deeply eroded the upland toward the river, reducing it to a succession of valleys and bluffs reaching back in some places only four or five miles, in others as much as thirty miles. There is also a series of south flowing streams which have eroded the surface far less deeply and usually flow at greater distances from one another. These south flowing streams have their sources near those of the north flowing streams, and the watershed between them is what is known as the Military Ridge. ${ }^{4}$ This ridge, with a considerable body of land on its southern and northern slopes, was one of the notable prairies of southern Wisconsin. It reaches practically from near Prairie du Chien to the Four Lakes region.

The southern part of this region differs widely from the northern. In the north the valleys are the more important, in the south the ridges. This is due to the comparative narrowness of the southern valleys and the width and flatness of the lands between. A comparison of the Pekatonica region with the Blue River region will make the difference clear. One thinks of the former as a part of the plain country, which it is ; the latter is distinctly a part of the hill country. The Pekatonica is a land with a stream flowing through it to furnish water and power. The Blue River is a valley made and domi-

${ }^{3}$ These ridges grew wheat successfully for some years after that cereal had ceased to be grown on the lowlands.

- Because the United States Military Road from Forts Howard (Green Bay) and Winnebago (Portage) to Fort Crawford (Prairie du Chien) was built in 1835 along the top of this ridge. It is now the line of a branch of the Chicago and Northwestern Railway. 
nated by a river system. The ridges between the south flowing streams are all extensive, sometimes eight or twelve miles wide; the ridges between Blue River and the Fennimore are so narrow as to show but little flat surface, while the best of the north trending ridges are only two or three miles in width and much of their surface is uneven, often steep. On the Military Ridge and portions of its slopes appear certain very fine silt loams supposed to have been deposited by the winds and called loess. These loams are generally mingled with weathered material.

Whether the whole of Wisconsin was at some time or times covered with forest growth we do not certainly know. But between the several advances of the ice sheet there was always time enough for soil to be prepared and for forests to spring up. A buried forest found in Manitowoc County and the lower Fox River valley ${ }^{5}$ is proof at least that such a growth occurred between the second and third glacial advances in that region. The remains consist of "logs, branches, and upright stumps."

When settlers began to arrive in Wisconsin they found the southern part of the territory divided between forest and prairie, the former predominating. ${ }^{6}$ The two maps, Figs. 4 and 5, show how these features were intermingled. ${ }^{7}$ These forests are described as either maple, pine, or oak, according to the kind of tree which predominated in a given area (Fig. 6). The principal maple area stretched northward from the south line of the state, along Lake Michigan to Green Bay. It was a narrow belt through Kenosha and Racine counties, but widened out across Milwaukee, Waukesha, and Jefferson counties, and occupied most of Ozaukee, Dodge, Fond du Lac, Winnebago, Calumet, together with portions of Sheboygan, Brown, and Outagamie. This forest, with the lower Fox River

- Lawrence Martin, The Physical Geography of Wisconsin, Wisconsin Geological and Natural History Survey Bulletin No. 36, Madison, 1916, 253-254.

- The question of the origin of the prairies is still unsolved. Probably forests covered the land fully at one time, and the absence of timber anywhere may bo taken as proof of its destruction (1) by fire, or (2) by root boring insects, leaf destroyers, or other pests.

${ }^{\top}$ Martin, op. cit., 126, 277. 


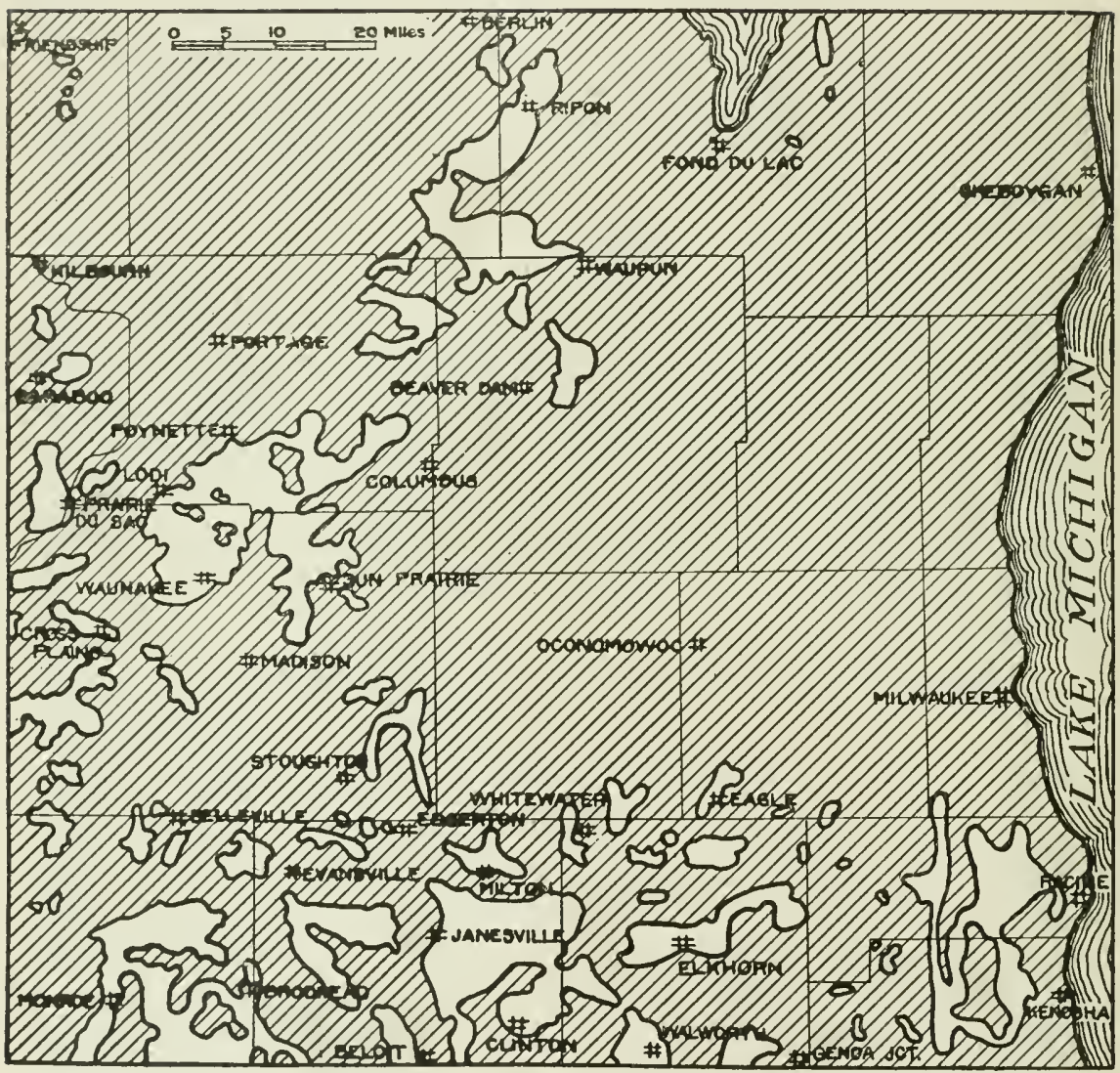

FIG. 4. THE ORIGINAL AREAS OF PRAIRIE-SHOWN IN WHITE - IN SOUTHEASTERN WISCONSIN

Courtesy of Wisconsin Geological Survey 


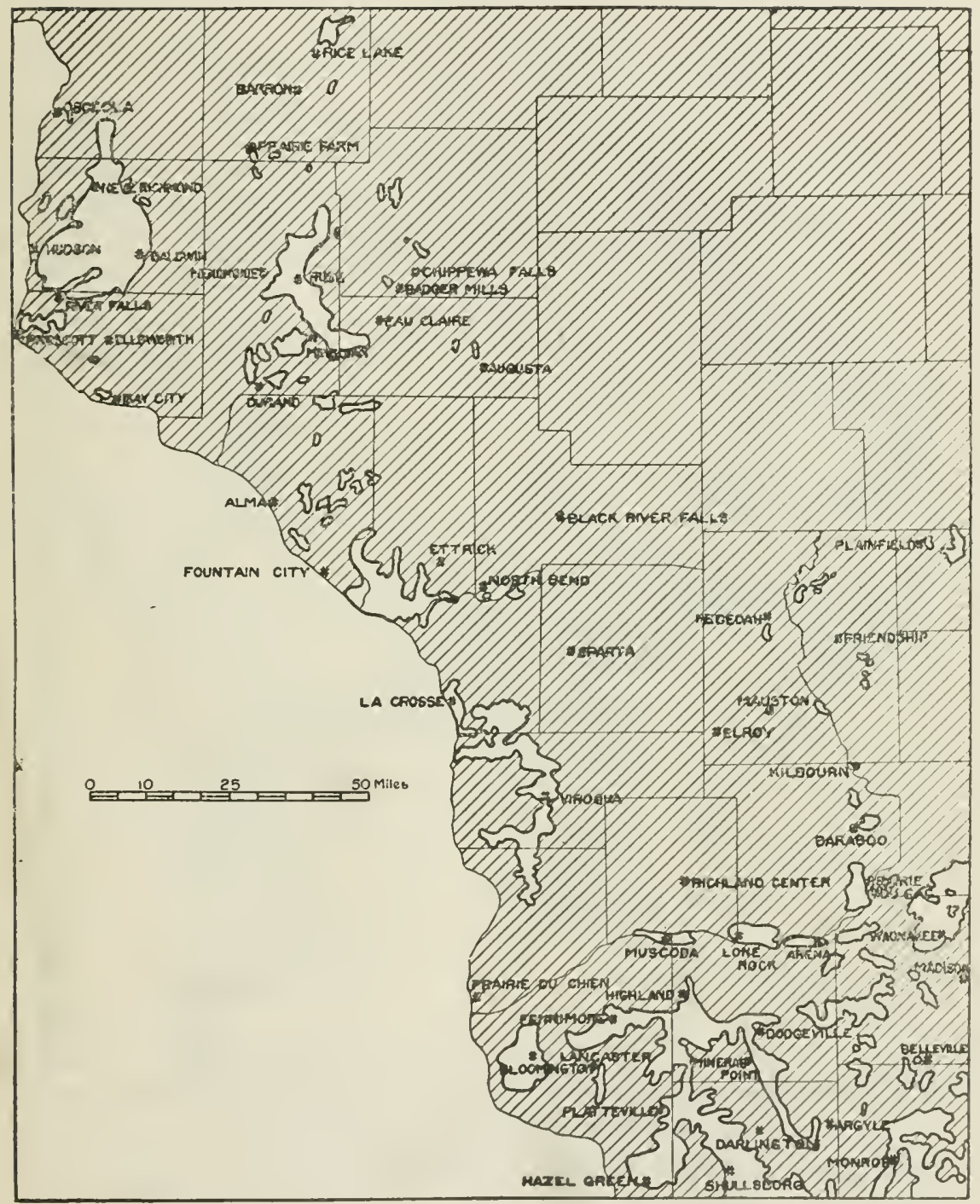

FIG. 5. THE DISTRIBUTION OF PRAIRIES-SHOWN IN WHITE-IN THE WESTERN UPLANDS OF WISCONSIN

Courtesy of Wisconsin Geological Survey 


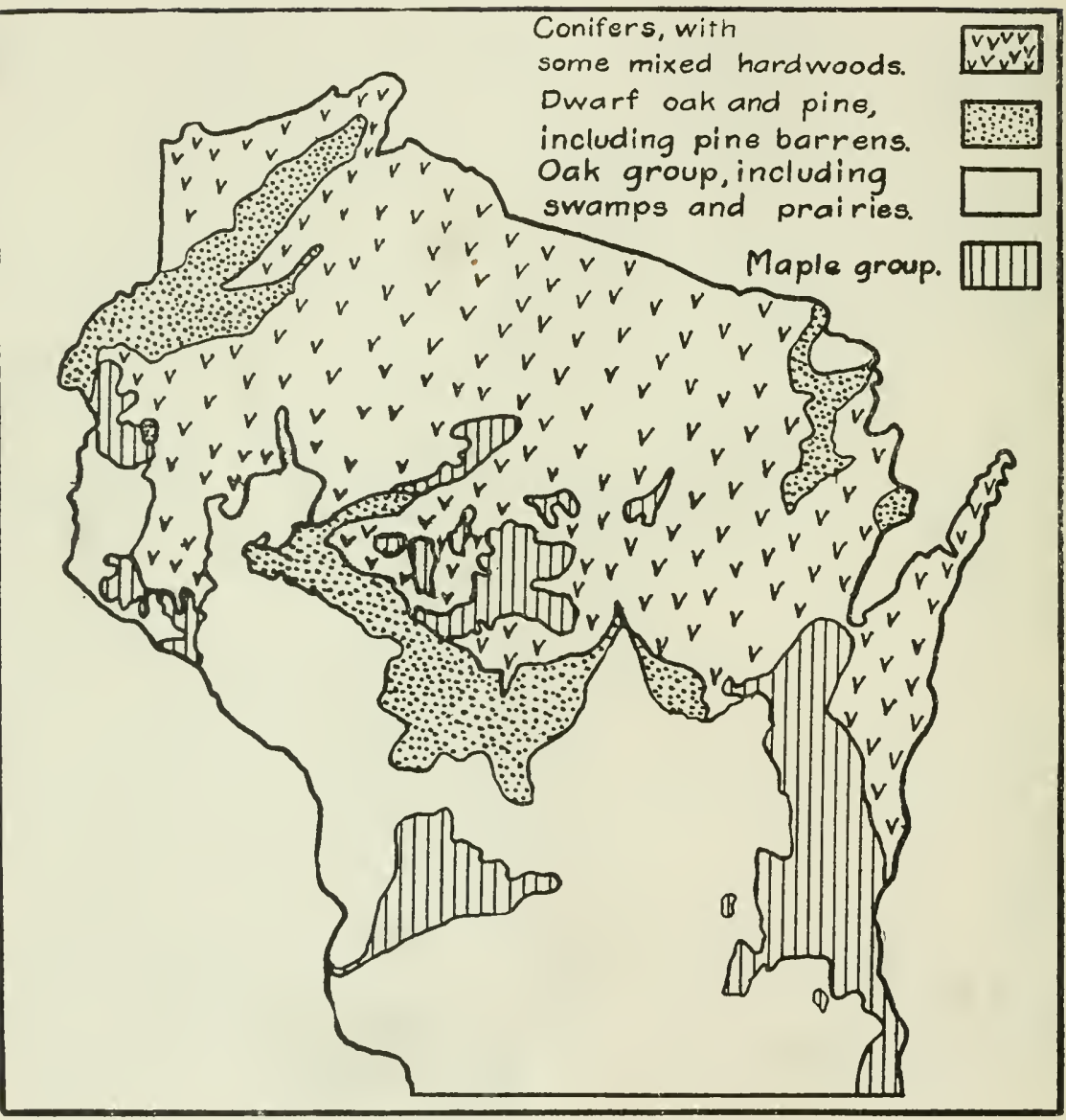

FIG. 6. FOREST MAP OF WISCONSIN

After Wisconsin Geological Survey, 1882 
and Green Bay, enclosed a flattish triangle of land fronting on Lake Michigan which constituted the only considerable pine forest of southern Wisconsin. It began on the lake shore just south of the Sheboygan County line in Ozaukee County, extended northwest to Lake Winnebago, thence northeast to Green Bay and throughout the Door Peninsula, covering Door County, Kewaunee County, Manitowoc County, with portions of Brown and Sheboygan. That forest, because of its convenient location, constituted one of the earliest of the pine lumbering regions of eastern and southern Wisconsin. A second maple area lay north of the Wisconsin and occupied most of Richland County, also the southern part of Sauk and the western third of Crawford. A third maple area lay in a straggling, blotchy manner over portions of Buffalo, Pepin, and Pierce counties, and a fourth covered parts of Polk and Burnett.

Aside from the regions just described, all the rest of southern Wisconsin (and the limestone sections of western Wisconsin) was either oak forested, studded with oaks in the form of openings, or treeless, in which case it was called prairie when dry and swamp, swale, or marsh when wet. The oak forests, like the maple and pine forests already described, had various other kinds of trees mingled with them-maple, hickory, walnut, lynn (linden), aspen, etc. In the openings, however, which were extensive and numerous, fires seem to have destroyed all of the other growths, leaving only the oaks, which are more resistant. Undergrowth, too, was burned away, so that the oak trees, set at varying distances apart on grass covered slopes or plain-land, lent to the landscape the appearance of a beautiful natural park within which, not infrequently, travelers saw herds of deer quietly feeding till startled by the human invaders of their paradise. The oak openings were easy to clear, they yielded some wood, and the soil was at first considered to be superior to that of the prairies. Therefore, the trend of early immigration set strongly toward the openings. 
The prairies of southern Wisconsin were grouped somewhat peculiarly within a broad belt along the southern and western portions of the great triangle formed by Lake Michigan, Illinois, and the Fox-Wisconsin line. If one were to draw a line from Fond du Lac at the south end of Lake Winnebago to Stoughton on Lake Kegonsa (First Lake), thence due east to Lake Michigan, practically all of the prairie lands would fall outside of that line. In the south, beginning at the lake, was an extensive prairie which occupied much of Kenosha and Racine counties; Walworth County had a number of small prairies, of which the most considerable was Elkhorn Prairie; Rock Prairie in the county of Rock was one of the largest and most famous of the southern prairies, and there were three other prairies worthy of mention in that county; while the neighbor county of Green had a prairie covering a large tract in the southeast and east, also one occupying much of the south and southwest. Small prairie tracts-a section or two, sometimes three or four in a body-were distributed in an east-and-west line to the north of those already described. West of Green County the "big prairie" was the one which, beginning near the Mississippi, followed the Military Ridge with several short breaks to Madison, and from the central part sent out lobes south to Hazel Green in Grant County, to the Illinois line, and to Argyle in Lafayette. The prairie just described could be followed again northeastward by way of Waunakee, Sun Prairie, Lodi, Waupun, and Ripon to the vicinity of Lake Winnebago west of Fond du Lac. The breaks which appear on the map between the distinct prairie areas on that line were mostly occupied with oak openings. It was therefore a very simple matter to open a military road from Lake Winnebago via these prairies and the Military Ridge to the Mississippi.

We have now accounted for most of the prairie districts of southern Wisconsin and, indeed, of the state. To the north of the Wisconsin, on the limestone foundation, there are but three areas requiring attention-the one in Crawford, Vernon, 
and La Crosse, terminating in what was long known as Prairie la Crosse; the second along the Mississippi in Trempealeau County (this is principally on the upper Cambrian formation); and the third in St. Croix County. The large prairie with small outlyers east of this in Dunn County, on the crystalline formation, was also important as affecting the settlement of that region.

It appears from a comparison of the forest map of the state with the geological map, that while the hardwoods were not confined to the limestone areas, yet, with inconsiderable exceptions, the limestone areas were actually covered, when forested at all, with forests of hardwood. The main exceptions were the Manitowoc region already described as pine bearing, and the limestone strip projecting south from the Michigan boundary to Fox River along the west coast of Green Bay, which was also a pine region.

Allied-to the prairies by reason of their freedom from the incumbrance of timber, so their surfaces could be mowed for hay as the prairies could be plowed without the previous labor of clearing, were the swamps or marshes. These sometimes supported groves of tamarack, cedar, or even pine, but were more commonly open land, heavily grassed, and when not too wet by nature or when partially drained, yielded an excellent quality of wild hay. The accompanying map (Fig. 7) shows the distribution of swamp land, and proves in a striking manner that both the Driftless Area and the region of older drift were free from swamps. They are found only in those sections of the state which received the last drift, called the Wisconsin drift; in other words, it was the third and last visitation of the ice sheet which left the marshes and lakes in its train. From this it is easily seen that such features are but temporary at best. The processes of erosion and deposition are tirelessly at work cutting down the stream levels here, filling in depressions there, so that area after area is being rescued from its swampy character and made into cultivable land. In due time, even without the powerful aid of man 


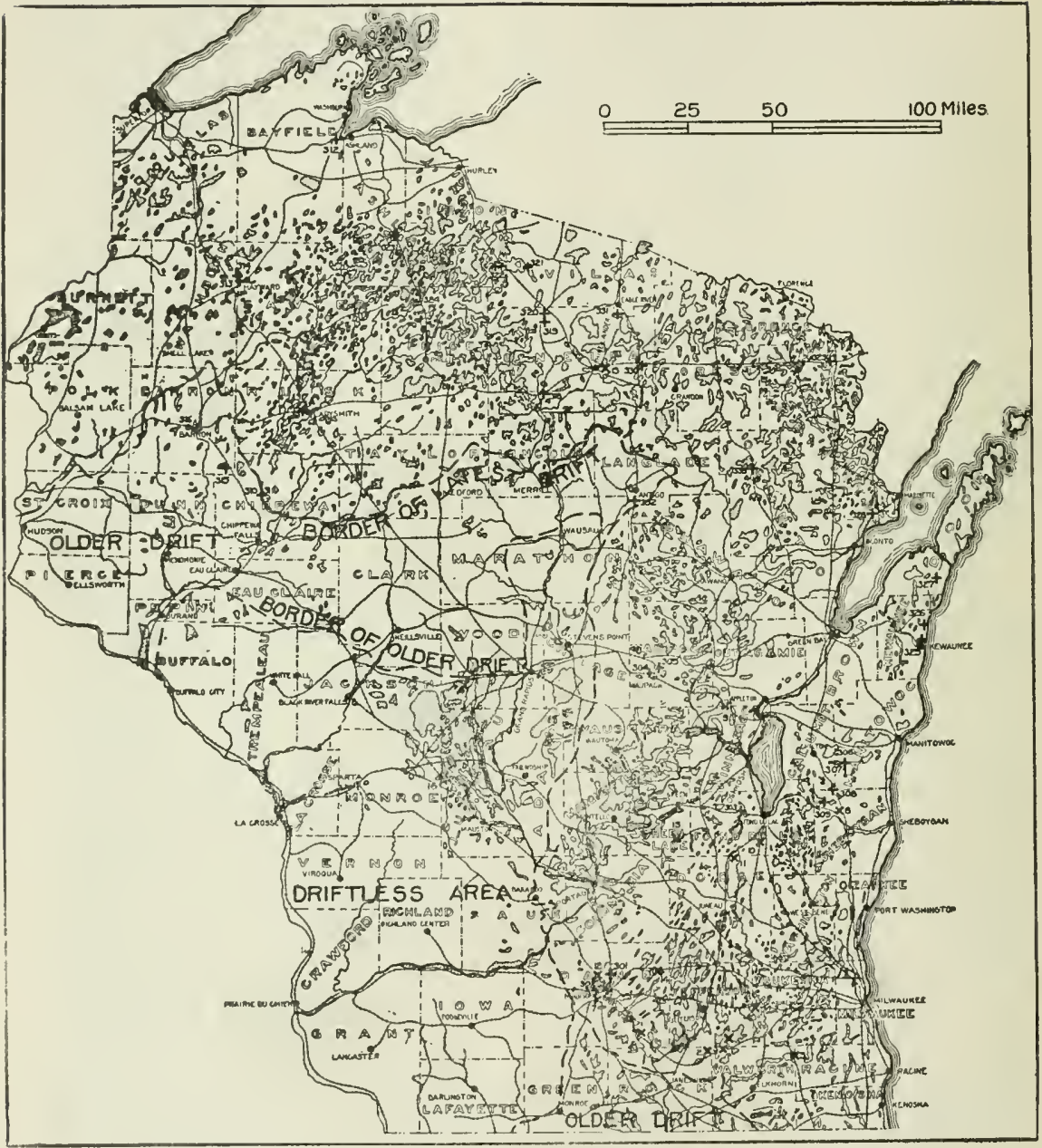

FIG. 7. THE SWAMPS OF WISCONSIN-DOTTED AREAS Courtesy of Wisconsin Geological Survey 
acting individually and coöperatively, the swamps and lakes of Wisconsin will as certainly disappear as does the winter's snow before the ardent rays of an April sun.

Summarizing the agricultural possibilities of the land in Wisconsin when settlement began, we may say: First, the region of the hardwoods and the prairies which, as has been shown, corresponded closely to the area underlain by limestone was decidedly the most available for immediate use. That was true for several reasons. For one thing, the surface, while diversified and in part hilly, was predominantly of a character to make it fit for farming purposes. The soil was generally fertile and under proper tillage capable of growing successfully all crops adapted to the climate. The swamp meadows of the glaciated portion, and the unforested hills of the driftless, supplied, the one an abundance of hay and pas:ture, the other ample out-range for cattle, thus offering encouragement for a livestock industry, which was further favored by the wide and general distribution of a natural water supply in springs, creeks, and larger streams. These streams also furnished the necessary water power for sawmills and gristmills, upon which new communities are so largely dependent, and some of them gave promise of a future great manufacturing development. This possibility, and especially the exceptionally favorable opportunities for transportation by inland rivers, by the Mississippi and the Great Lakes, captivated the imaginations of home seeking Americans and later helped to draw to this region many thousands of thrifty, intelligent farmers of foreign birth. The limestone region, except in the northeastern lobe, which was a pinery, was all fully populated by the year 1870. The rest of the state had then only scattering settlements. Here is sufficient proof of the preference shown by early settlers for the hardwood and prairie limestone lands. Second, the number and extent of the oak openings and of small prairies sheltered by forests made opportunities for opening farms with both ease and safety, plowland cleared or almost cleared being intermingled 
with woodland, which at first all American settlers deemed to be indispensable. Third, where the forest covering was heavy, as in most of the maple areas, clearing after all was not an impracticable task, although it involved hard and persistent labor, because, the trees once cut off or girdled, the stumps quickly rotted away. Besides, the heavy forest lay near the lake coast, where growing cities were sure to call for fuel wood, charcoal, pot and pearl ashes, and railroad ties, all of which gave the settlers some small compensation for the labor of clearing.

The farming resources of northern Wisconsin, which now are so large and varied, will be discussed in a later chapter. It is only necessary to point out here that it was not exclusively the conditions of soil and surface which deterred settlers from taking the pine lands of the limestone area as readily as the hardwood lands. There was a widespread belief that hardwood trees were a guaranty of fertile soil, and it was also well known that pine stumps would remain in the ground indefinitely to hamper cultivation after the trees were slashed or girdled, while stumps of the hardwoods quickly rotted away, leaving the fields fully cleared and subject to the plow.

\section{SOURCES}

In preparing this chapter the most helpful single source was Lawrence Martin, The Physical Geography of Wisconsin. Other numbers in the publications of the Wisconsin Geological and Natural History Survey which afforded much aid were Ray Hughes Whitbeck, The Geography and Industries of Wisconsin (1913), The Geography of Southeastern Wisconsin (1921), and The Geography of the FoxWinnebago Valley (1915); also, Leonard S. Smith, The Water Powers of Wisconsin (1908). Some use was made of the several Soil Surveys, and much of Hotchkiss and Thwaites, Model of the map of Wisconsin. 


\section{CHAPTER II}

\section{EARLY SETTLEMENTS}

The lands of any country are important for the human opportunity they represent. The use which is made of them depends upon the people who come into their possession. For long ages the lands of Wisconsin made their mute and ineffectual appeal to the natives. Then came a few French who were intent mainly upon trade such as the wild life of forest, stream, and swamp would yield when exploited by native huntsmen and trappers. Small, haphazard settlements grouped about the trading posts, especially those at Green Bay and Prairie du Chien, were all the French contributed toward the actual taming of the wilderness, their numbers being too restricted to build a New France between the Great Lakes and the Father of Waters. ${ }^{1}$

The British occupation of the territory, after the treaty of Paris, 1763 , was practically an extension of the fur trading era and need not, any more than the French, concern this story of the agricultural development of Wisconsin. Both French and English transmitted important benefits to the later sovereigns of the soil, though not in the way of its cultivation. Their most valuable contributions lay in the exploration of the country, the mapping and testing of its communication lines, and the partial description of its resources. Even the precarious settlements they maintained were indirectly useful to American pioneer farmers for their service of supply; and their influence, with some exceptions, tended to make the

${ }^{1}$ The early, romantie period of Wisconsin is well treated, in brief form, in Reuben G. Thwaites, Wisconsin (Buston, 1908), and more fully in Louise Phelps Kellogg, Early Wisconsin (in prenaration). Dr. Kelloge has ruhlisher a shorter study of Wisconsin, 1634-1848, in the Wisconsin Magazine of History, volumes ii and iii. 
Indians a support rather than a hindrance to agricultural settlers. ${ }^{2}$

When American settlement began, it was not at first agricultural. Instead of the attractions of prairie and opening, it was the subtler lure of underground mineral wealth which attracted the first few thousand. They came with the eager impetuosity which always characterizes the "rush" to new mining districts. The lead region occupied that portion of the Driftless Area (see Fig. 8) which is underlain by the GalenaBlackriver formation. This includes the counties of Grant, Lafayette, Iowa, and a portion of Green in Wisconsin, also Jo Daviess in Illinois and Dubuque in Iowa.

The lead, zinc sulphate, and zinc carbonate, familiarly called by miners "mineral," "blackjack," and "drybone," occur mainly in rock crevices or pockets which exist in the Galena phase of the Galena-Blackriver limestone. Sometimes deposits are found in the Blackriver also and, very rarely, in others above and below. ${ }^{3}$ By locating the eastern boundary of the Driftless Area, and noting the northward and westward projection of the Galena-Blackriver formation, the area of the lead deposits can be readily determined.

The lead deposits were known by the French as early at least as 1687; mines near the present Galena were shown on French maps from the first years of the eighteenth century, and the mines of that district were actually worked, though by crude methods, during that period. From that time until about 1819 the story of lead mining is a chequered oneFrench, Indians, Spanish, and a few English and Americans participating in it. Julien Dubuque, from his "Spanish Mines" across the river, had exploited the Galena district with the aid of Indians for many years prior to his death in 1810. But when the United States took control under an

3 This is particularly true of the French influence. On account of the War of 1812 , the later British influence was directly unfarorable though the trade of both French and English tended naturally toward the pacification of the Indians.

See Ulysses S. Grant, Report on the Lead and Zinc Deposits, Wisconsin Geological and Natural History Survey Bulletin No. 14, Madison, 1906. 


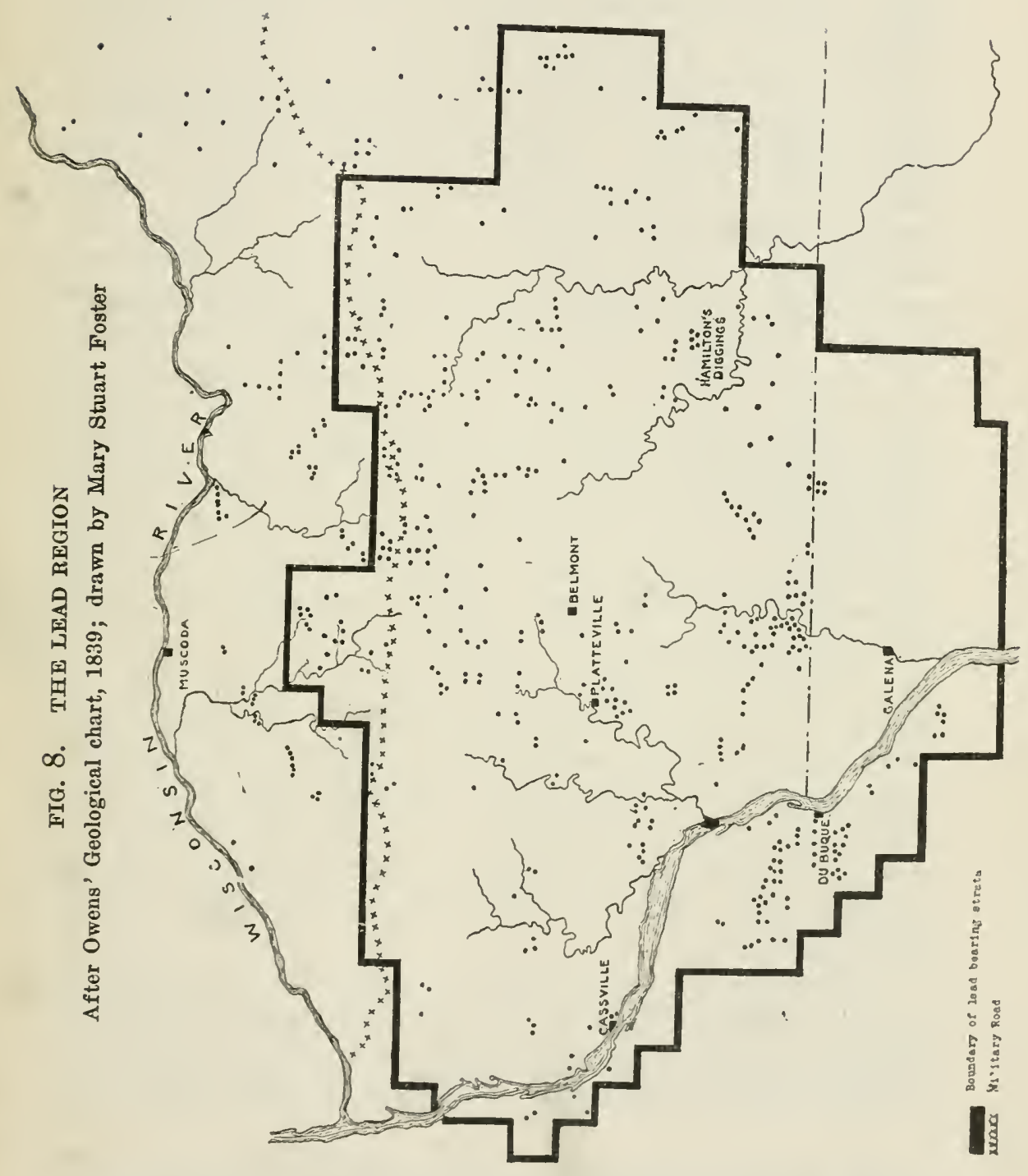


agreement with the Indian claimants of the land in 1819, when Jesse W. Shull, James Johnston of Kentucky, and others began mining systematically, a new era opened for the lead mines. In a few years the richness of the deposits came to be widely known, especially among the people of southern Illinois, Missouri, and Kentucky, and the mining community was augmented by every steamboat ascending the Mississippi to Fever River (Galena). In 1826 and 1827 several hundred came. They spread up through the Wisconsin district, reaching the northern limits of the lead region before 1829. A map published at Galena in 1829 shows how the main "diggings" were distributed." It shows also beginnings of towns in names like New Diggings, Shullsburg, Cassville, Platteville, Dodgeville, and especially Mineral Point, the acknowledged center of the Wisconsin lead district. It shows trails into the lead region from southern Illinois and from Chicago, and trails out to Green Bay, Fort Winnebago, and Fort Crawford, to Arena and English Prairie (Muscoda) on the Wisconsin, and to Cassville on the Mississippi. Galena was still the main local trade center for the entire northern lead region, while St. Louis was its commercial metropolis.

A serious interruption of the prosperity of the miners was caused by the Black Hawk War of 1832, in which numbers of them volunteered for military duty. But its result was the extinction of the Indian title to practically all of the lands comprising southern Wisconsin as defined by the Illinois boundary, Lake Michigan, and the line of Green Bay, Fox River, and Wisconsin River to the Mississippi, thence that river to the Illinois line. ${ }^{5}$

The mining community, being already well established, resumed its activity after the war and continued to develop in a notable manner for several years prior to the settlement of other sections of Wisconsin. A census in 1836 assigns to the

"See Reuben G. Thwaites, "Notes on Early Lead Mining," in Wisconsin Historical Collections, xiii, 271-292; also map of lead region in ibid., xi, 400.

${ }^{3}$ For an account of the war and the treaties, see Reuben G. Thwaites, Wiscon. sin, chap. ix. 
territory 11,683 persons. Of these the county of Iowa, which at that time included also the later Lafayette and Grant counties-essentially the lead region-had 5234. Brown County, comprising the entire Green Bay region, the Fox River valley, and Lake Winnebago, had 2706. Crawford County, which was settled only in the neighborhood of Prairie du Chien, had 850. These three constituted the established settlements, and it will be seen that the lead region was more populous by 1678 persons than the other two counties combined. The other area showing settlements, all practically new, was Milwaukee Comty, which embraced the entire southeastern portion of Wisconsin (see Fig. 9). These scattering communities, hardly a year old, numbered 2893 persons. To this new region we must now direct attention.

As soon as the Indian cessions were made, in 1832-33, government surveyors entered Wisconsin. Beginning at the Illinois boundary as a base line, they ran the Fourth Principal Meridian due north through the heart of the lead region to Wisconsin River. ${ }^{6}$ Then they laid off ranges of townships on both sides of the line, always terminating, for the time, at the Wisconsin-Fox River boundary. By the end of the year 1835 the map of that part of the state, the older Wisconsin, was chequered with the surveyors' townships except in the southeastern part, which was surveyed in 1836 (see Fig. 10).

But the work of the government surveyors meant much more to settlers than the mere locating of township lines and section lines. The surveyors made the first detailed examination of the land, recording their estimates of its qualitywhether first class, second class, or third class-described the surface as level, rolling, rough and broken, or swampy, and indicated the kinds and the comparative density of the timber along the lines surveyed. They located the oak openings, the prairies, high rolling prairies, low wet prairies, level dry

\footnotetext{
- That meridian was afterwards made the boundary between Grant County and Iowa and Lafayette counties. Ranges of townships in Wisconsin are numbered west and east of that meridian.
} 


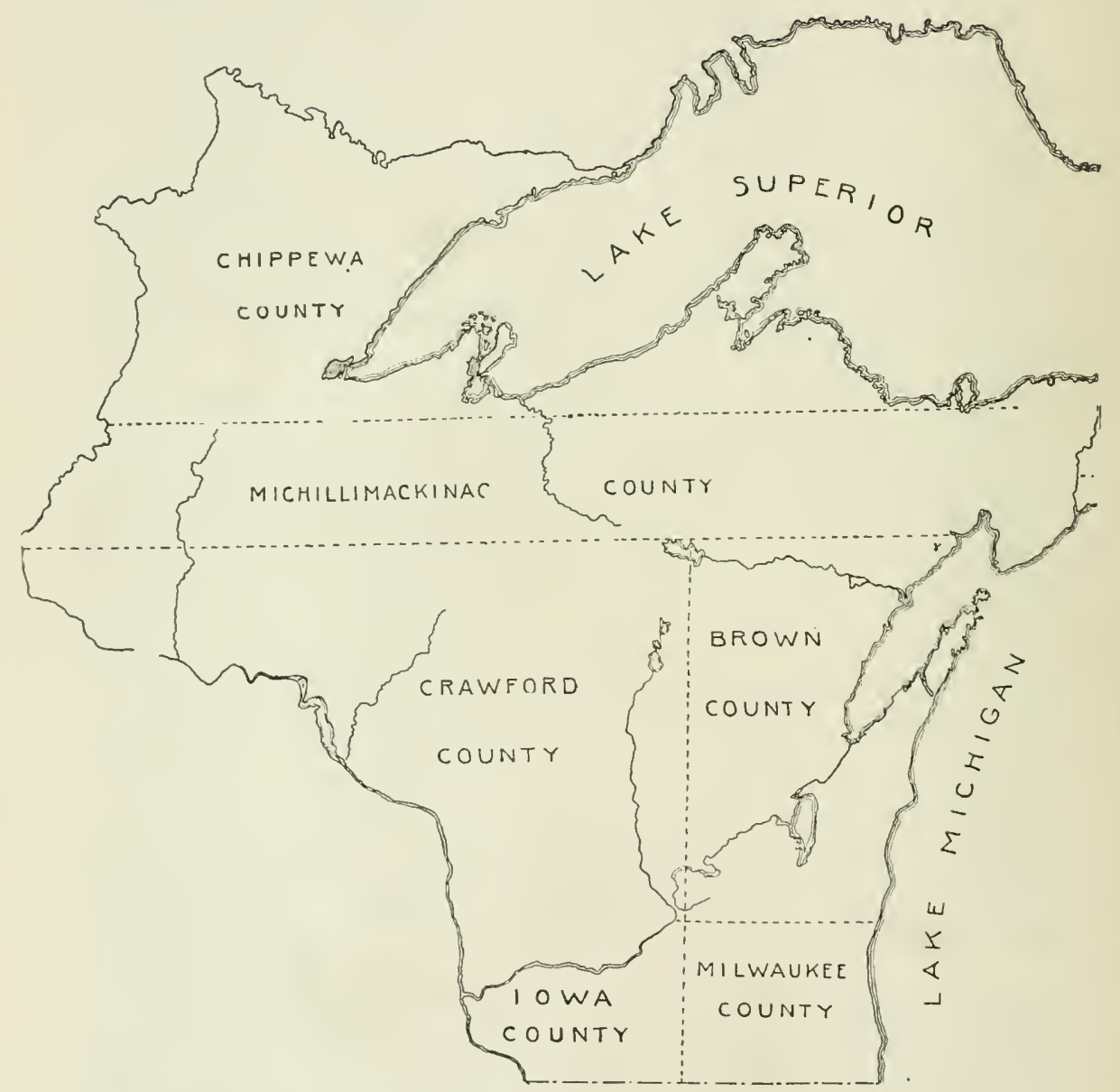

FIG. 9. MAP OF COUNTIES IN 1836 
EARLY SETTLEMENTS

29

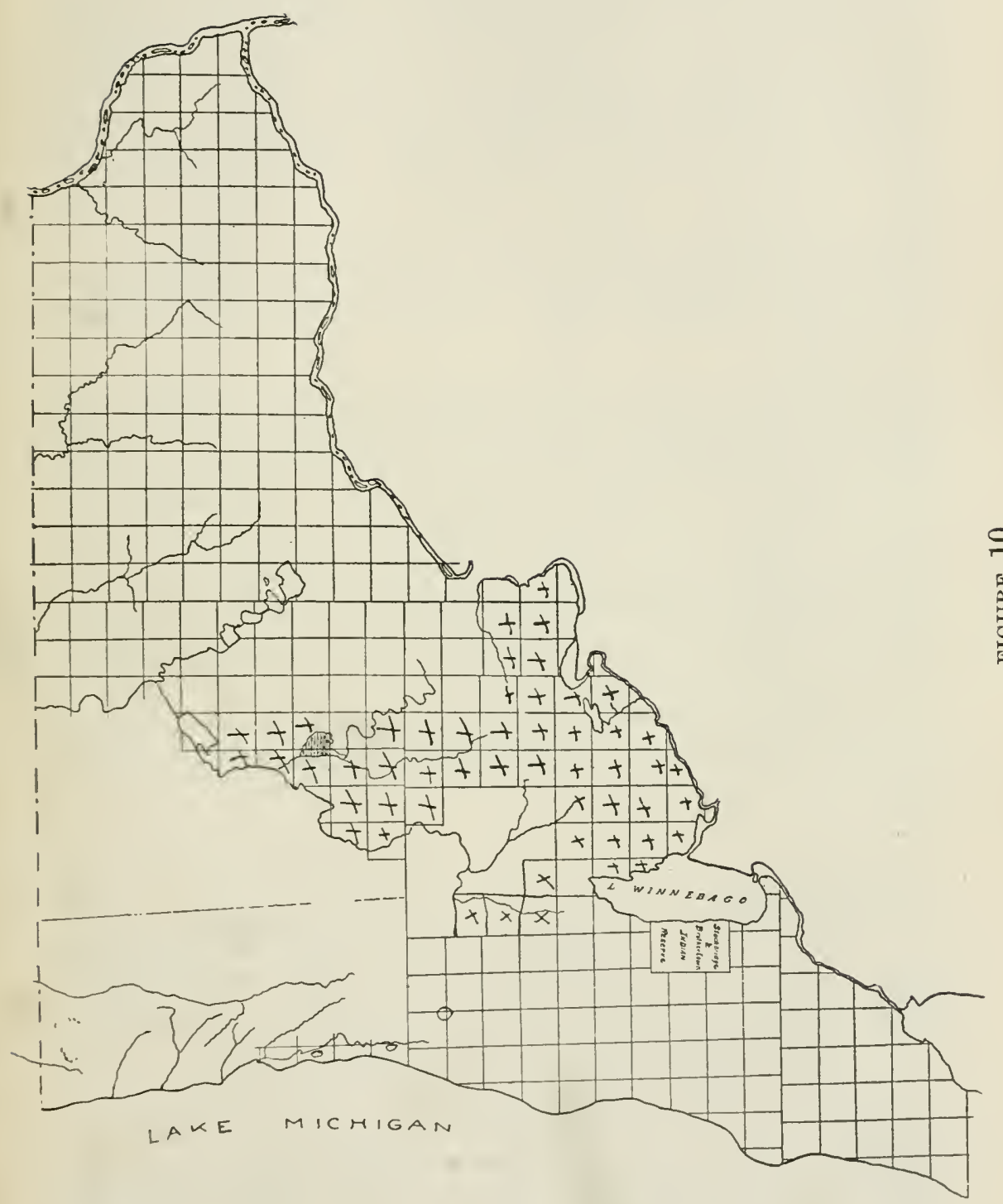


prairies, etc. ${ }^{\top}$ In a word, they noted the points about the lands surveyed which settlers were most keen to know, and this information could be procured by land seekers, at slight expense for copying, from the government land office. ${ }^{8}$ Armed with copies of the surveyors' plats and transcripts of his notes, the land seeker was equipped for the arduous task of selecting favorable locations for the opening of new farms, while the speculator was enabled by their means to choose likely town sites, mill sites, or lands that might soon be wanted for agricultural purposes. Some of the surveyors themselves were tempted to speculate in the lands they knew so well, and no doubt their special knowledge was often placed at the service of friends.

Accordingly, when in 1834 the government established two land offices for western Michigan Territory-one at Green Bay and one at Mineral Point_a "land office business" in the sale of lands to speculators began at once. They bought up river frontage where steamer landings prophesied the establishment of river towns; they secured for town sites valley lands at junctions of streams; water powers were eagerly sought out and the lands about them entered; while timbered strips along the rivers, in the prairie regions, or other fine groves, which would be needed by later farmers, were bought up in the confident expectation of their prompt and advantageous sale to settlers. ${ }^{9}$

\footnotetext{
${ }^{7}$ See survey notes in margins of plats in Atlas, Wisconsin Domesday Book, Town Studies, I (in press).

${ }^{8}$ The surveyors were usually men of fairly good scientific training and were keen observers. Some of them, like Lucius Lyon, afterwards United States senator from Michigan, attained distinction in political life. A surveying party usually consisted of the surveyor, an ax-man, and two chainmen. The State Land Office at Madison has a complete collection of the notebooks of Wisconsin land surveyors, also all original survey plats. The romance of the land surveying period has almost wholly escaped the American novelist.

- The land office tract books contain the records of sales. When these are compared with the surveyors' plats and notes, the story of speculation is revcaled, and one sees usually just what advantage the speculator sought to secure when he located his land. Names of many distinguished Americans appcar on the plats of Wisconsin lands. We note among them Daniel Webster, Edward Everett, Caleb Cushing, and Ralph Waldo Emerson. Timbered lands in western New York, in 1830, were considered quite as valuable as the best farming lands. So there was seen to be good business sense in buying timbered lands.
} 
However, the speculative furore, which temporarily collapsed with the panic of 1837, expended itself mainly in the western ranges of townships surveyed early, and thus the splendid farming territory now embraced in Rock, Walworth, Kenosha, Racine, Milwaukee, Waukesha, and Jefferson counties remained almost wholly open to the selections of prospective settlers.

Settlement in the southeastern counties of Wisconsin forms an excellent commentary on the process of settling the wild lands of the country as a whole. Theoretically, it might seem as if the lands would have been taken first directly along the lake front wherever ports were within reach, and thereafter the belt of settlement would gradually widen away into the interior, the means of communication being created as fast as the increments of new settlement required. In fact, no such regularity in settling a new country has ever been observed. The geographic and social facts which imparted their impulses to the agricultural occupation of southeastern Wisconsin were mainly three: first, the existence of the lead mining region of northwestern Illinois and southwestern Wisconsin, whose interests tended to converge upon the Mississippi and Rock rivers; second, Chicago, city of destiny, building up near the foot of Lake Michigan and eagerly seeking ways of concentrating lake trade at that port; third, the foresight shown by the builders of Milwaukee, that for successful rivalry with Chicago their port must establish roads, canals, or other means of drawing commerce from the interior.

The lead mines themselves constituted at first no inconsiderable market for agricultural produce,,$^{10}$ and it is not surprising that farmers should have desired the fine prairie lands in the vicinity of Rock River, particularly in the days when the navigability of that stream for steamboats was almost an article of religious faith. Rock River was a tributary of the Mississippi, and the entire lead region continued for a number

${ }^{10}$ In 1843, by the act of August 3, the lead miners were permitted to purchase their claims. Thereafter farming became a more important feature of life in the lead region. 
of years to look to St. Louis as their metropolis. But Milwaukee's builders saw the significance of the Rock River valley, as well as the mines, and promptly projected their Milwaukee and Rock River Canal, which, although it ultimately failed, had a powerful effect in directing settlement along designated lines, promoting road building, and binding the interests of large areas occupied by new communities to the lake port at Milwaukee.

Fox River (or the Pishtaka) is a branch of the Illinois. The lower portions of its valley, within the state of Illinois, began to be settled almost as soon as the discussions in the Illinois legislature advertised the prospect of a canal connecting the lake at Chicago with Illinois River. Such a canal would open out a market by the lakes, while Illinois River, like the Rock, connected with the Mississippi. Fox River itself was supposed to be navigable for flat-bottomed boats as far as Rochester in Racine County, fifty-four miles by a direct course from the Illinois line. To a generation which still relied on the flatboat as a means of marketing its surplus products, farming in the vicinity of such a stream, even without a canal, seemed a reasonably safe, normal manner of life.

So it was that pioneers ascended Fox River, marking out claims at attractive points; others ascended Rock River or reached it overland from Chicago by the prairie trails almost as early as the founders of Racine and Kenosha took cognizance of the promising lake ports south of Milwaukee. And once a lodgment was effected in the river valleys themselves, the intervening prairies and openings were scoured for mill sites, town sites, and the choicest farming situations, ${ }^{11}$ all in advance of the construction of roads or the canals which promoters were promising. But the land office records show that, in general, the farm locations fixed upon had a very definite relation to prospective improvements like canals, roads, and

\footnotetext{
${ }^{21}$ See Vanderpoel's letter in Racine Argus, June 2, 1838. Fine description of two beautiful farm sites already occupied in 1837 in the district between Fox and Rock rivers.
} 
later, railroads, or to existing facilities for marketing products, especially by the rivers.

The movement which resulted in the first occupation of the southeastern counties began in 1835 . It attained considerable vigor in 1836 and 1837, and by the end of the year 1839 the region may be considered settled, though much good land was to be had for some time thereafter. It was a movement in which hundreds were engaged at the same time, and while some localities were occupied a little earlier and some a little later, as the local histories show, for the purposes of this general statement it is sufficient to regard the principal settlements as having taken place about the same time. These principal settlements were near the lake shore, from the southeast corner of Kenosha County north almost continuously to the Milwaukee County line; along Fox River in both Kenosha and Racine counties; ${ }^{12}$ along Rock River, near Beloit, Janesville, and farther north, also west of the river, on the prairie; at Lake Geneva, Troy Lake, Whitewater, Delavan, Spring Prairie, Elkhorn Prairie, etc. in Walworth County. The Fox River line was followed northward into Waukesha County, as was the line of Rock River and its tributaries, and the proposed canal, into both Waukesha and Jefferson counties, settlers always being guided by the opportunity of securing ideal locations near the natural or artificial lines of communication and transportation.

It is possible with the aid of the records of entries and purchases, with the surveyors' description of the land, the topographical charts prepared for some areas by the United States Geological Survey, and the soil surveys (available in a few cases) to exhibit minutely the settlers' choices among kinds of land. A good illustration is township 3, range 22 east, which is a part of the town of Mount Pleasant, in Racine County, whose eastern boundary is Lake Michigan and which contains the port of Racine. The chart (Fig. 11) shows that the eastern ranges of sections were taken up at the earliest possible time,

${ }^{22}$ Kenosha County was set off from Racine County in 1850. 
$\angle A N D$ ENTRIES MT PLEASANT

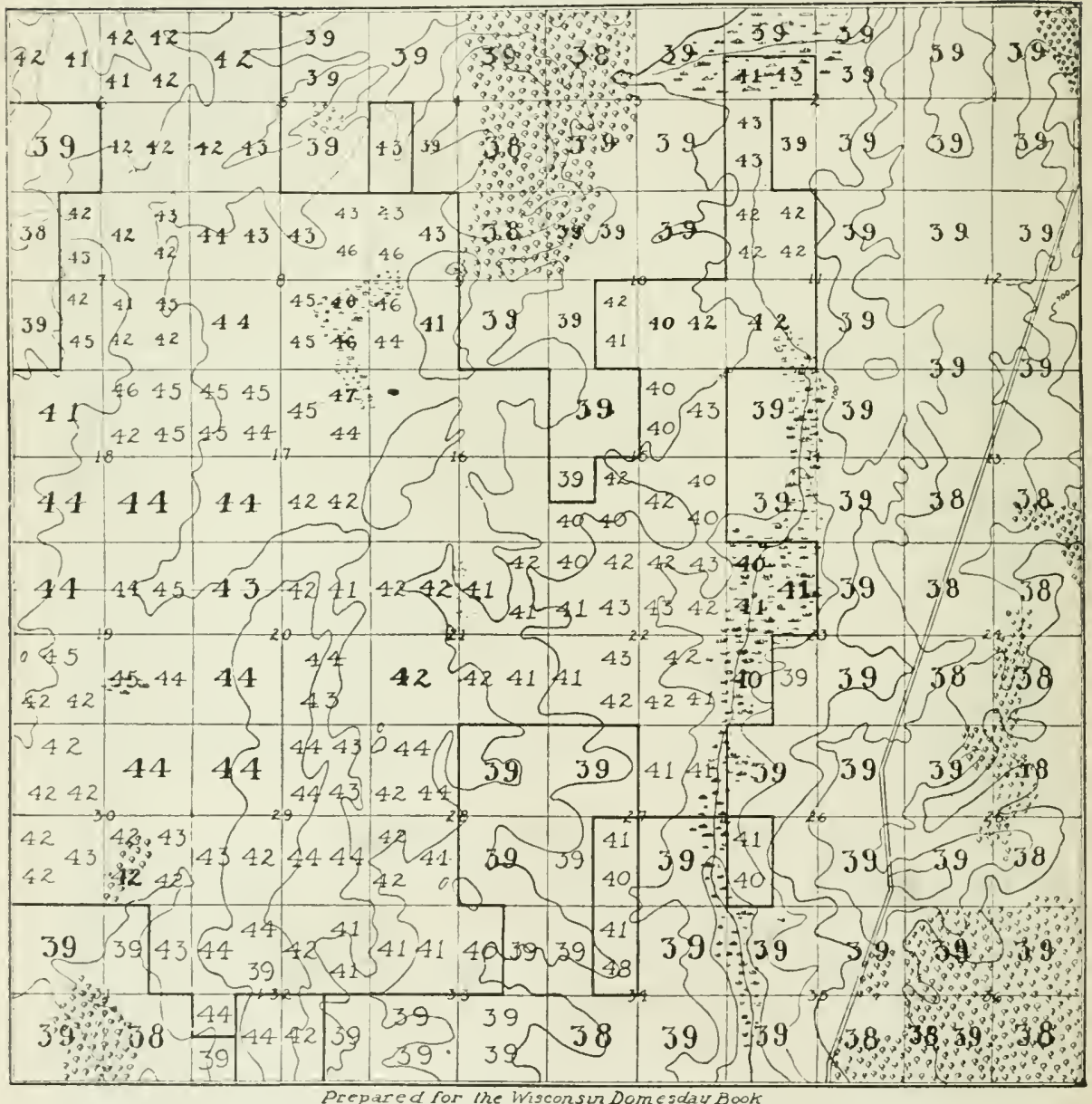

FIG. 11. LAND ENTRIES, RACINE COUNTY 
in 1838-39, the first land sale at the Milwaukee land office. Some of the southern sections and some of the northern sections were taken at the same time, together with small detached areas elsewhere; but the great body of land in the western and central portions of the township was left for later purchase, some of it going as late as 1846. According to the surveyor, the land which was shunned by the earliest comers was quite as good, on the whole, as that which was taken first. Why was it left?

The township in question is a prairie township. Most of the land is described by the surveyor as bigh prairie and the contour lines on the topographic chart show lowlands in only two principal areas, both of them narrow and inconsiderable as compared with the broad ridges. A few small depressions occur in the prairies themselves. Within the easternmost of the long low strips-the one along the course of Pike River and above its head-are the only extensive marshes in the township, though a smaller marsh occupies the second trench, in sections 8,9 , and 17 . There are practically no openings, though patches of forest relieve the otherwise undiversified prairie character of the land. The chart indicates, generally, the distribution of forest, high prairie, low prairie or meadow, and marsh land. All of the sections in the easternmost range had some timber on them except 12 , and a body of timber lay just east of that section. There was also timber in 35, 31, a little in 30 , a considerable body in 3 and 4, 9 and 10 . Sections 6 and 7 abutted on a "grove" in township 3 , range 21 east. A road, hardly better than a trail at the outset, crossed diagonally from section 35 to section 1 - the socalled Chicago-Green Bay road. At an early date also another territorial road was opened through the northern part of the town from east to west. The marshes along Pike River may be considered an obstacle to easy road making from the main road into the central portion of the township, but this obstacle disappears at the south as well as at the north. 
Our land-entries cards show that the easternmost range of sections and the easternmost half of the next range were entered at once on the opening of these lands to sale. ${ }^{13}$ Beyond that, the purchases were sporadic. They included low ground, but not the lowest, along Pike River-lands which adjoined the preferred sections-also some other low land in the south, the timbered tract in section 31, three tracts toward the northwest which had timber at their western margin, and all of the big grove in the north, with some tracts of adjacent prairie. But the big, open, unsheltered prairie occupying the middle and western portions of the township was left for several years as "cow commons" for the farms ranged around it.

The facts brought out in this study are reinforced by those which emerge in the study of other towns. They show that the early pioneers appreciated timber when found, in sparse measure, in a prairie region. They loved to build their homes in the shelter of woods. They preferred a tract of woodland as a portion of their holdings, but at any rate they wanted wood within easy reach. For plow land they chose the high prairie because it was well drained, or land of the same character in the openings. If they could have this as the main portion of their farms, with forty or eighty acres of timber and an equal quantity of low prairie or meadow, they were content. Those who entered a new region early enough to pick and choose, invariably selected lands which gave them these three elements of fundamental utility. The first claim takers in Mount Pleasant obtained them approximately. Later comers, observing that the vacant lands were too exclusively prairie, swerved off toward Fox River, or took the prairie trails to Rock River, or went up into Jefferson, Waukesha, or Dane County in order to lay the foundations of their farms in the right kinds of land properly distributed. It was only when they began to realize the counter disadvantage involved in hauling their surplus wheat twenty, thirty, fifty, or one hundred miles over heavy roads to the lake ports (which they

\footnotetext{
${ }^{25}$ Most of those lands, to be sure, had been "claimed" and settled upon earlier, some as early as 1835 , the bulk of them in ' 36, ' 37 , and ' 38 .
} 
in the beginning hoped to avoid by shipping on rivers and canals), that they saw the possibilities in the left-over lands lying within eight or ten miles of such ports. ${ }^{14}$ Then the big prairie in Mount Pleasant was promptly taken up, and by the end of 1846 there was nothing left except the school section and a few small pieces of swale land.

It is noteworthy that nearly all those who entered government lands thus early, in Kenosha, Racine, Walworth, and Rock counties, bore names which show their possessors to have been Americans, or at least English speaking persons. And the testimony of those who describe the early settlements is that the people were mostly from New York and New England. The testimony of the census is to the same effect. For example, in 1850 Mount Pleasant in Racine County had a population of 1101 ; of that number, 842 were native born, 259 foreign. There were 144 American families and only 48 foreign families. Similar statistics are obtained for Whitewater in Walworth County, which had 992 American and 234 foreign born. In Plymouth, Rock County, were 377 American born persons, and 194 foreign born. The county of Racine in 1850 had a total population of 15,004, with 8867 natives and 6083 foreign born. Kenosha County's figures were 10,735 native and 3383 foreign born, while Walworth had 14,865 to 2787 and Rock 16,435 to 4201 . These statistics show a great preponderance of native born in those counties taken as a whole. ${ }^{15}$

Going north to Milwaukee County and to Washington County the case is different. In 1850 Milwaukee County had 18,229 foreign born as against 12,685 native, while Washington County had 12,100 foreign and 7252 native.

Thus it appears that some condition, which in Washington County at least could not have been the presence of an impor-

1s Many of the early settlers left New York and Vermont at a time when new canal projects were being prosecuted to completion almost yearly. It is little wonder they should have faith in a project as secmingly feasible as the Milwaukee and Rock River Canal.

${ }^{25}$ I am using, in the county statistics, the results of a hand count made for the Society by Dr. M. M. Quaife, with an assistant. 
tant town, was causing the northern counties to be settled largely by people of foreign birth. A study of the land entries for the town of Franklin, Milwaukee County, shows that the earliest entries were made mainly by English speaking persons who, in rather numerous eases, were Irish or of Irish descent. But many of the American entrymen appear to have bought for speculative purposes, or at least decided in a few years to sell their lands, for the transfers became numerous in the forties, and by 1850 there were only 15 American families to 285 foreign. ${ }^{16}$ The foreigners included 282 persons born in Germany, 292 born in Ireland, and 39 in Holland. All other countries furnished 58.

The one significant contrast between the lands of Racine County and those of Milwaukee, Ozaukee, and Washington counties is that the former are prairies and openings, with some dense groves; the latter are heavily forested for the most part. It might seem from this that American settlers preferred the more open lands, while immigrants from foreign lands preferred to begin in the woods. The case, however, is not so simple. We have already seen that the ideal farm, to the American settler, was a combination of timber, prairie or opening, and marsh-for fuel and shelter, cultivation, and hay or pasture. Now, the above is precisely the "ideal farm" for the ambitious immigrant as well as for the native. William Dames, an intelligent German immigrant of 1848, after much search found such an ideal tract. It had, he says, "160 acres in prairie, 320 acres openings and 160 acres meadow together with some marsh along the shores of Rush Lake." "17 The same writer speaks of the "murderous toil" of clearing a farm in the heavy timber, which he regards as a life job for the unfortunate settler. Why, then, did so many German immigrants elect to spend their lives in making farms under those conditions?

\footnotetext{
${ }^{16}$ In this count the family is classified by the birthplace of its head. Frequently the children of foreign parents were natives.

${ }^{17}$ William Dames, Wie Sieht es in Wiskonsin Aus (1848).
} 
The answer is found, by analogy, in this other question: Why do the poorer people, in every crowded city, live on the low grounds, while the well-to-do occupy the high, commanding, and sightly knolls? It is at bottom a question of economic ability, not of personal or racial tastes. The poorer immigrants and the poorer natives also, with of course many exceptions, settled in the woods because they could not afford to encounter the risk of taking an ideal farm in the "Congress land" districts, nor could they afford to buy such land from speculators or from farmers. They took what was at hand, the heavily wooded lauds avoided by persons who were in position to pick and choose. In many cases they might have found lands on the open prairies, which, as we saw, were taken later than the other lands even by Americans who had some means. But the person without means would have been helpless in such a situation. He would need money to buy lumber both for building and for fencing, while in the timber his personal labor supplied these essentials, without cost, in the process which at the same time cleared his land. Besides, the timbered areas near Milwaukee had the advantage of a good market not only for the agricultural products to be raised after the work of clearing was done, but even for some of the incidental products of clearing, like cord-wood, pot and pearl ashes, charcoal, and later, railway ties. Where the timber was largely or partly merchantable pine or cedar, as in the counties north of Milwaukee along the lake, the sawmills and shingle mills furnished a market. Thus the settler on a woods claim, if physically equal to the labor involved, might hope to supply his family with necessities at least from the forest products of his farm, while extending, year by year, his cultivated area. In the end his farm might even be a better one than if it had been on the prairie, for a portion of it was always fresh land, and there is some reason to believe that farms rescued from the forest by dint of the indomitable labor of the pioneers are generally more highly appreciated by the 
second and third generations than are the prairie farms. ${ }^{18}$ But the creation of such farms was an heroic process, entailing real hardships, unremitting toil, and privations for many years.

The forested area in the eastern portion of Wisconsin included the counties of Milwaukee, Washington, Ozaukee, Sheboygan, Manitowoc, Kewaunee, Door, Brown, Calumet, with parts of Fond du Lac, Dodge, Jefferson, and Waukesha. Of these, several, including Door and Kewaunee, were still unorganized in 1850, and there was but a small population in Brown, Manitowoc, and Calumet. The census count, however, assigns a large majority of foreign born not only to Milwaukee County, where the city had early attracted considerable numbers of Germans, but to Washington and Manitowoc also. The other counties of the group show native born majorities, though in Sheboygan, Brown, Fond du Lac, and Waukesha the foreign born number more than one-third of the total. On the other hand, the northern portion of the heavily forested area was a decade or more behind southeastern Wisconsin in its development. Manitowoc County, for example, where lumbering began very early, waited for the settlement of its farm lands on the heavy influx of Germans who arrived between 1848 and 1854, and the same population element pressed into parts of Sheboygan, Fond du Lac, Brown, and other northern counties.

A study of the early maps will show how definitely the locations of agricultural settlements were determined by marketing possibilities. Captain T. J. Cram's map, 1839, reveals clearly that, outside of the mining region, the farm settlements were east of a line that followed Rock River to Watertown and ran thence north to Fond du Lac. But, in fact, only the portion of that strip which lay south of a line drawn from Watertown due east to the lake was actually settled except at intervals along Lake Michigan, if we except the beginnings of Fond du Lac itself and Oshkosh, with a few paper towns on

\footnotetext{
${ }^{18}$ Joseph Schafer, "The Town of Newton, Manitowoc County," in Wis. Mag. of Hist., v. 144-159.
} 
Lake Winnebago and, of course, Green Bay. To the west of our assumed line lay Madison, founded in 1837 as the capital of the Territory because its choice was the most satisfactory compromise between the lead mining region and the lake. There was not much farming done in that part of the Territory for a number of years, nor in the prairies and openings northward from Madison to Fox River, nor in all of the country north of the Military Road and west to the Mississippi. Such places as appear on the map along Wisconsin RiverPrairie du Sac, Arena, Helena, "Muskoday"-_have significance merely as trading points in relation to the lead mines, not in relation to an agricultural community. ${ }^{19}$ It was early discovered that, while the Mississippi steamers were an invaluable resource for bringing in necessaries, carrying away lead ore, etc., freight charges due to the difficulties of its navigation would prove prohibitive for shipping farm produce. Hence, only those living near enough to the lake ports to make possible the delivery of wheat, by team over execrable roads, could really farm. Settlers in Rock River valley marketed their crops in that manner for more than a decade. Yet, even they complained that on account of the cost of transportation, the more they had to sell, the poorer they became; while those living farther west had practically no outlet either south or east. ${ }^{20}$

It was the coming of the railways which changed these untoward conditions and made farming a normal occupation beyond the limits of wagon transportation for farm products, at the same time giving a tremendous impulse to wheat raising in the southeastern counties by reducing the cost of marketing. ${ }^{21}$ The Milwaukee and Mississippi Railway, begun in

${ }^{20}$ Helena was the place where Daniel Whitney's shot tower was located. Lead brought there in wagons was cast and the shot carried away by steamer either via the Portage and Green Bay or via the Mississippi. Muscoda was the location of a smelter maintained at the river by William S. Hamilton. The lead was brought by a down-hill haul from the prairie to the south.

${ }^{20}$ Balthaser H. Meyer, "Railway Legislation," in Wis. Hist. Colls., xiv, 213.

${ }^{n}$ See Josiah F. Willard, in Wisconsin State Agricultural Socicty, Transactions, $1853,116$. 
1849, built gradually westward by short sections and sent its surveyors forward alread of the construction parties. Our record of land entries shows that prospective settlers usually reached an area about to be tapped by the railway very soon after the surveyor's had located the road. Many made purchases before the road was built, but not long before. Pioneering, for its own sake or as an expression of ingrained habit, was rather uncommon among the Easterners as well as among the foreigners who settled southern Wiseonsin.."2 All wanted land, however, and the railways into new regions multiplied opportunities to secure the kinds of land most desired. Hence the spaces noted as open in 1839 are no longer unoceupied on the map of 1853 . Hence, also, some spaces north of the Wisconsin, in Crawford, Richland, and Sank counties, are shown to be settled at the later date.

Since statehood was achieved in the year 1848, it is interesting to determine approximately how the agricultural settlements were distributed at that time. The political symbol of the rural settlement is the organized town, which usually, after a district of country beeame fully settled, was a surveyor's township six miles square. 'These towns were organized in the varions counties as they were needed to accommodate the people. Sometimes, in the beginning of settlement, a district embracing several townships, or even a whole county, was made a town for loeal government purposes, to be subdivided as settlement thickened up. Hence, a map showing the organized towns with dates of their organization will describe the farming eommunity of the state at the given date, and also show the progress of settlement. The accompanying map (Fig. 12) of sonthern Wisconsin shows (1) the surveyor's townships. (2) In heavily shaded figures, the organization of towns by the legislature to 1848. These early towns, as will be seen, generally embraced several townships, sometimes

${ }^{22}$ In this respect conntitions in carly Wiseonsin contrasted sharply with those in the early stages of community building in some of the other states, like Kentueky, southern Illinois, and Missouri. However, is it not possible that in American history we have generally overstressed the idea that men have chosen the life of backwoodsmen rather than aceepted it as a matter of stern necessity? 


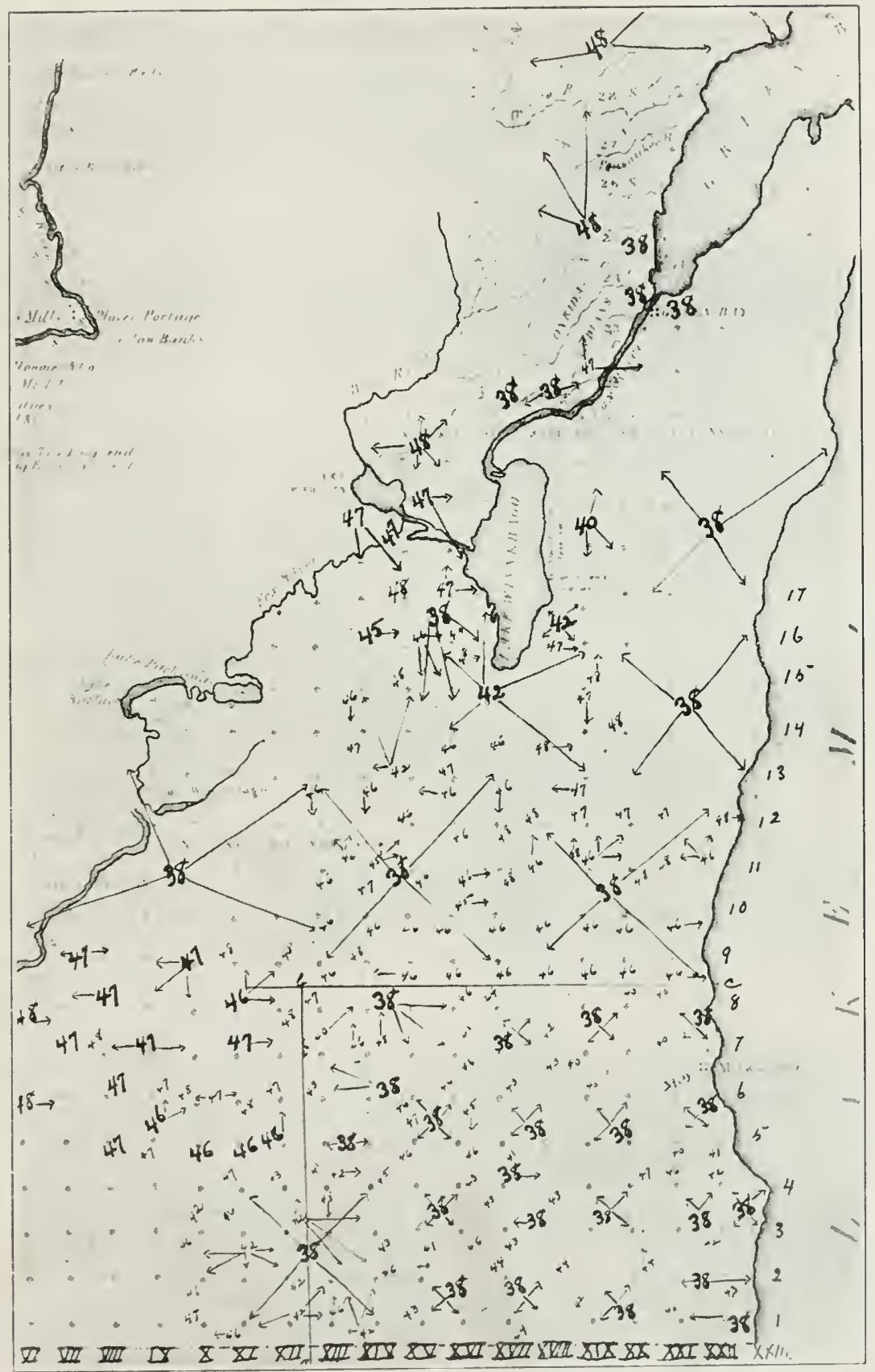

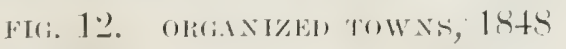



entire counties. (3) In lighter shaded figures, the dates of organization of towns within older and more spacious towns. (4) Those portions, within the lines of the map, which remained unorganized as late as 1848, the date of the latest session laws examined in this study. All portions of the state falling outside of the lines of the map were unorganized. For example, the lead region, though longer settled, was not at this time organized into towns. This is generally attributed to the fact that the dominant element there was accustomed to the comnty form of local government. 'The constitution, however, provided for the uniform adoption of the town system over all the state, and the southwestern counties were soon accordingly subdivided into towns. However, as previously pointed out, the lead region was not primarily an agricultural section.

The figures, therefore, which are in all cases the last two digits of the number representing the year (as " 38 " for " $\left.1838^{\prime 2}\right)$, constitute a fairly accurate picture of the manner in which settlement spread over the state and the rate at which it concentrated in given areas. The lines $a-b$ and $b-c$ enclose, with Lake Michigan and the Illinois boundary, the one great area which was sufficiently settled by 1838 to justify its subdivision into towns smaller than counties. That area embraces the counties of Walworth, Racine, Kenosha, also Milwaukee, Waukesha, and parts of Rock and Jefferson. Dane County, with Green and the northwestern part of Rock, remained undivided until 1846-47, portions of them longer. About Lake Winnebago were one town dating from 1840, two from 1842, and one from 1845. Aside from these, only two towns were organized prior to 1846 in the farming area north of the line $a-b$. Also, soutl of that line many of the separate erections came as late as 1845,1846 , and 1847 in the northwestern part, while in the east, south, and southwest portions of the region they generally came earlier. The towns around Green Bay took care of the organization of the old French. Canarlian trading settlements. In none of the towns organ 
ized prior to 1846, save three or four in western Rock County, were the farmers living at a greater distance than sixty miles, in a direct line, from the lake. Those who were farming along or near the northern border of southern Wisconsin found a temporary market in the lumbering districts near at hand.

The census map for 1850 reveals on the whole a similar result, but it does not discriminate between agricultural settlements and those incident to mining and lumbering. It shows an area along the lake coast, through Kenosha, Racine, and Milwaukee counties, which is peopled to the density of 45-90 to the square mile. That is of course due in part to the lake towns. The balance of what the preceding map shows to have been the farming area distinctively has 18-45. Most of the lead region, with considerable territory adjacent to it in the north and east, also the Sheboygan County area, has but $6-8$. The rest, symbolizing merely pioneer beginnings north of the Wisconsin and near the river, the thinly populated old settlements about Green Bay, the several lumbering regions on the Wisconsin and the Chippewa, also on the Mississippi, and the Lake Superior colonies, has only 2-6 to the square mile. All of these areas except the lumbering tracts in the interior and those on the upper lake are located on the limestone formations.

\section{SOURCES}

In preparing this chapter I have used Ulysses S. Grant, Lead and Zinc Deposits (Madison, 1906); the Collections of the State Historical Society of Wisconsin; various items and volumes; and the Wisconsin Domesday Book plats and records, MS., some of which are in press and will be issued as Wisconsin Domesday Book, Town Studies, I. 


\section{CHAPTER III}

\section{PIONEER ORIGINS}

The grand inquest which the United States government conducts every tenth year under the name of the Census results in the assembling and recording of a vast store of facts about the people of every state, as well as about farming conditions, manufacturing, and general business. In taking the seventh census $(1850)^{1}$ in Wisconsin there was usually an official enumerator for each organized town, while unorganized territory was divided into districts, to each of which a census taker was assigned. These men traversed the country by the usual roads, visiting the roadside homes in regular order and making side trips to see those living off the roads. Sometimes they failed to find anyone who could give correct information at home; in such cases they filled in their blanks with the aid of the neighbors or left the families off the list entirely. They often set down incorrect statements about particular persons or families, either because their information was wrong or because they misunderstood it. The latter was especially apt to be true of foreign born families whose members could not speak English, whose names were strange, unpronounceable, and the spelling impossible to Americans. Occasionally they did not attempt to spell them but wrote down, instead of the name, the descriptive word "Dutchman" or "Norwegian." Quite naturally, less care was exercised in obtaining accurately the facts about foreign born persons and families than those about the Americans and the English speaking British, Scotch, Welsh, or Irish. ${ }^{2}$ Still, the census

${ }^{2}$ The first census was taken in 1790. Then followed (2) 1800 , (3) 1810 , (4) 1820 , (5) 1830, (6) 1840, (7) 1850. The census of 1920 is number 14.

2 But sometimes hundreds of names of Irish laborers were taken from the rolls of railway contractors for whom the men were working; in such cases ages, etc. were omitted. 
gives us the best record we have, and it is an important source for the study of the population of the state. ${ }^{3}$

Taking the grand total, as given by the census, of 305,391 inhabitants of Wisconsin in 1850, we could reasonably classify them as (1) American born; (2) English speaking foreign born; (3) non-English speaking foreign born. In the first class we would have approximately 198,000; in the second, 47,840; and in the third, 58,400. The last two numbers, added together, represent the aggregate of those born outside of the United States-106,240, or more than one-third the total population of the state.

The first class may again be subdivided according to the regions in which the American born population originated, into Eastern and Northeastern, Southern and Southwestern, Northwestern, and Wisconsin. Placing these elements in the order of numerical importance, we have: ${ }^{4}$

Eastern and Northeastern............. 103,371

Wisconsin bor'n. . . . . . . . . . . . . . . 63,015

Northwestern ................... 21,367

Southern and Southwestern........... 5,425

Total..................... 193,178

The second class, English speaking foreigners, divides readily into four groups, as follows :

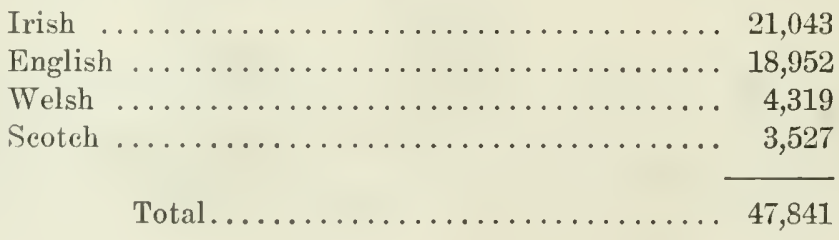

"The State Iistorical Society has the MS. agricultural schedules of the United States Census for Wiseonsin for the seventh, eighth, ninth, and tenth censuses, and the fop;ulation sehedules for the seventh, eighth, and ninth. These seliedules constitute the basis of mueh of our work on the Wisconsin Domesday Book.

' In this tabulation we have disregarded numbers which were small and of no special signifieanee. The resulting total is consequently about 4000 below the eensus total of American born.

"The British-Americans, numbering 8277, were mainly Freuch-Canadians and they are aceordingly elassed with the non-English speaking foreigners. 
The third class is composed of five groups:

\begin{tabular}{|c|c|}
\hline Hermans & 38,054 \\
\hline $\begin{array}{l}\text { Scandinavians (all Norwegians except } 146 \text { Swedes } \\
\text { and } 88 \text { Danes) } \ldots \ldots \ldots \ldots \ldots \ldots \ldots \ldots \ldots \ldots\end{array}$ & 8,885 \\
\hline Swiss & 1,244 \\
\hline Duteh (Hollanders)................. & 157 \\
\hline British-Americans (French-Canadians)... & \\
\hline
\end{tabular}

A further analysis of the first group of class one, Americans born in the eastern and northeastern states, discloses the startling fact that 68,595 of the 103,370 came from New York. Vermont was second with 10,157, Pennsylvania third with 9570. Appreciable numbers came from Massachusetts and Maine. Of the third group, 21,367, those born in the northwestern states, Ohio furnished more than one-half, or 11,402. Illinois contributed 5292, Indiana 2773, Michigan 1900. The southern and southwestern group (group four) is made up of small numbers contributed by the several states more or less equally, Virginia and Kentucky leading, each with less than 2000. Since the first of the four native groups was so predominantly large and since the non-English speaking foreigners were of recent arrival in Wisconsin, it follows that the majority of the Wisconsin born, group two, must have been the children of the eastern and northeastern immigrants.

The census, by counties, enables us to show with reasonable accuracy how these classes were distributed in 1850, and the map (Fig. 13) has been prepared for the purpose of revealing what elements predominated in each county. Of the 26 counties for which figures were obtained, all but three-Manitowoc. Milwaukee, and Washington-have a majority of native born. And in 21 cases the two elements natives of New York and natives of Wisconsin combined make a majority of this native majority. The exceptions are the counties of Grant, Iowa, Lafayette, Green, and Richland. The last named has a very small number, and the case may as well be omitted as possessing no significance. In Green County 
it becomes necessary to combine the Ohio born with those from New York and Wisconsin to make a majority of the native element, though the largest numbers came from New York and Wisconsin. Only the three lead region counties are peculiar. In Grant, the largest numbers were from Illinois, Wisconsin, and Ohio, these three aggregating more than one-half the total native population. In Iowa County the order is Illinois, Wisconsin, and New York; and in Lafayette, Illinois, Pennsylvania, and Wisconsin. Thus natives of Illinois in each of the three lead counties were numerically in the lead, and they were not first in number elsewhere. Moreover, the total number of persons born in Illinois who were residents of Wisconsin in 1850 was but 5292 , and these three counties contained 2353 of these, or not many less than one-half. The lead region, therefore, was where the "Suckers" went.

These Illinois natives were prevailingly from the southern half of that state, which had been settled from the Southwest and the South. They accordingly may be said to reinforce that element which found the lead region especially congenial, as the census shows. For example, there were only 1012 Missourians in Wisconsin in 1850. But the lead counties had 840 of them! The state harbored 1429 natives of Kentucky. The lead region furnished homes to 993 of them. Of Tennesseans Wisconsin had only 449. The lead region had absorbed 317 of these. There were 322 North Carolinians in the state; in the lead region were 127 . Virginia contributed to the state 1611 , to the lead region 778 . The other counties bordering on Illinois were fairly uniform in their American element, though Green County, the western portion of which was also in the lead district, had not enough New Yorkers to make up, with those born in Wisconsin, one-half of that element. ${ }^{6}$ In Rock, Walworth, Kenosha, and Racine the New Yorkers were very numerous. In Walworth they constituted more than one-half of the American born, in each of the other three

\footnotetext{
- The western half of Green County was in the lead mining region and had some Cornish miners as well as many Illinois people.
} 
counties nearly one-half. New Englanders, too, were relatively prominent. Rock County had nearly 1200 Vermonters and 1700 from the other five northeastern states. Walworth had 2250 from New England, Kenosha 1300, and Racine 1650. In all those counties the southern and southwestern element was negligible, and the northwestern element, aside from those born in Ohio, nearly so.

Not only was the lead region peculiar in the selection of its large majority of American settlers, but it was equally peculiar in the selection of foreign settlers. In all three of those counties natives of England were the dominant foreign element in their population complex, and each had a different second largest foreign element-Lafayette, Irish; Iowa, Welsh; and Grant, German. Now the English, while making the second largest number in the foreign element of five or six of the other counties, stood first in only one of them. ${ }^{7}$ The reason for the presence of 6670 Englishmen in these three counties was precisely that they contained the lead mines. These English were in part smelters and mine bosses who came from Yorkshire, but chiefly miners from the tin mining district of Cornwall. ${ }^{8}$ Thus it is seen that in this interesting section of the state, where the rock strata were warped, cracked, and creviced by geologic forces in the primordial ages of the earth, and these apertures filled with ore, which men learned to extract, there was developed, on the basis of a peculiar industry, a society which differed widely in its composition from that of the strictly farming districts. When at a later time the farming interest in the lead bearing area became dominant, this social condition, as we shall see, was destined to change. Many new people came in, but large numbers of the one-time miners settled down to the less venturous and exciting occupation of agriculturists.

In its foreign element Green County had 364 Swiss. These were the nucleus of the noted New Glarus colony, begun in

\footnotetext{
' Walworth, aside from two cases of counties having insignificant populations in 1850-Richland and Adams.

'Louis A. Copeland, "The Cornish Element in Southwestern Wisconsin," in Wis. Hist. Colls., xiv, 301-334.
} 
1845 by emigrants from the canton of Glarus, Switzerland. ${ }^{9}$ In 1850 their number amounted to one-twentieth of the total population of the county, and in 1890 it was about one-third. ${ }^{10}$ Here is a striking instance of the survival of a foreign element under conditions such as existed in early Wisconsin. This change illustrates also the trend in Wisconsin away from the social dominance of the eastern Americans to that of the descendants of foreign immigrants. However, the process was one extending over many years, and the influence of the Easterners was in many respects rendered permanent through educational, religious, and social institutions which they introduced.

In Rock County's foreign element the lead was already taken by the Norwegians, who numbered 1241. The nearest second was the Irish, with 915. Following them, in regular order, came English, Canadians, Scotch, Germans, and Welsh. The Norwegian emigration to America is said to date from the coming of the "sloop folk" from Stavangar in 1825, and the forming of a settlement near Rochester, New York. In 1834 several families removed to Ottawa in the Fox River valley of Illinois, and thither came many emigrants from the old world in 1836 and 1837 . The Ottawa colony was the western hive from which the Norwegians swarmed, mainly west and south, during the early forties. Others, coming to Milwaukee in 1839, formed colonies in Waukesha and Rock counties. Racine County also received a goodly number and soon became a mecca for Norwegians. ${ }^{11}$ The census of 1850 shows the three counties of Dane, Rock, and Racine to have had the largest numbers, in that order-Dane, 2779; Rock, 1241; and Racine, 678. The town of Norway in Racine County was set-

- See the admirable history of the founding of the New Glarus colony, by John Luchsinger, in Wis. Hist. Colls., viii, 411-445; also, the same author's "Planting of the Swiss Colony at New Glarus,' in ibid., xii, 335-382.

${ }^{10}$ Another Swiss colony dwelt, in 1850, in the southeastern part of Sauk County. The census assigns 331 persons of Swiss birth to that county. The Sauk County Swiss colony was the birthplace of ex-Governor Emanuel Philipp, whose parents were of that immigration.

${ }^{1}$ George T. Flom, A History of Norwegian Immigration to the United States (Iowa City, Ia., 1909), 121-123. 


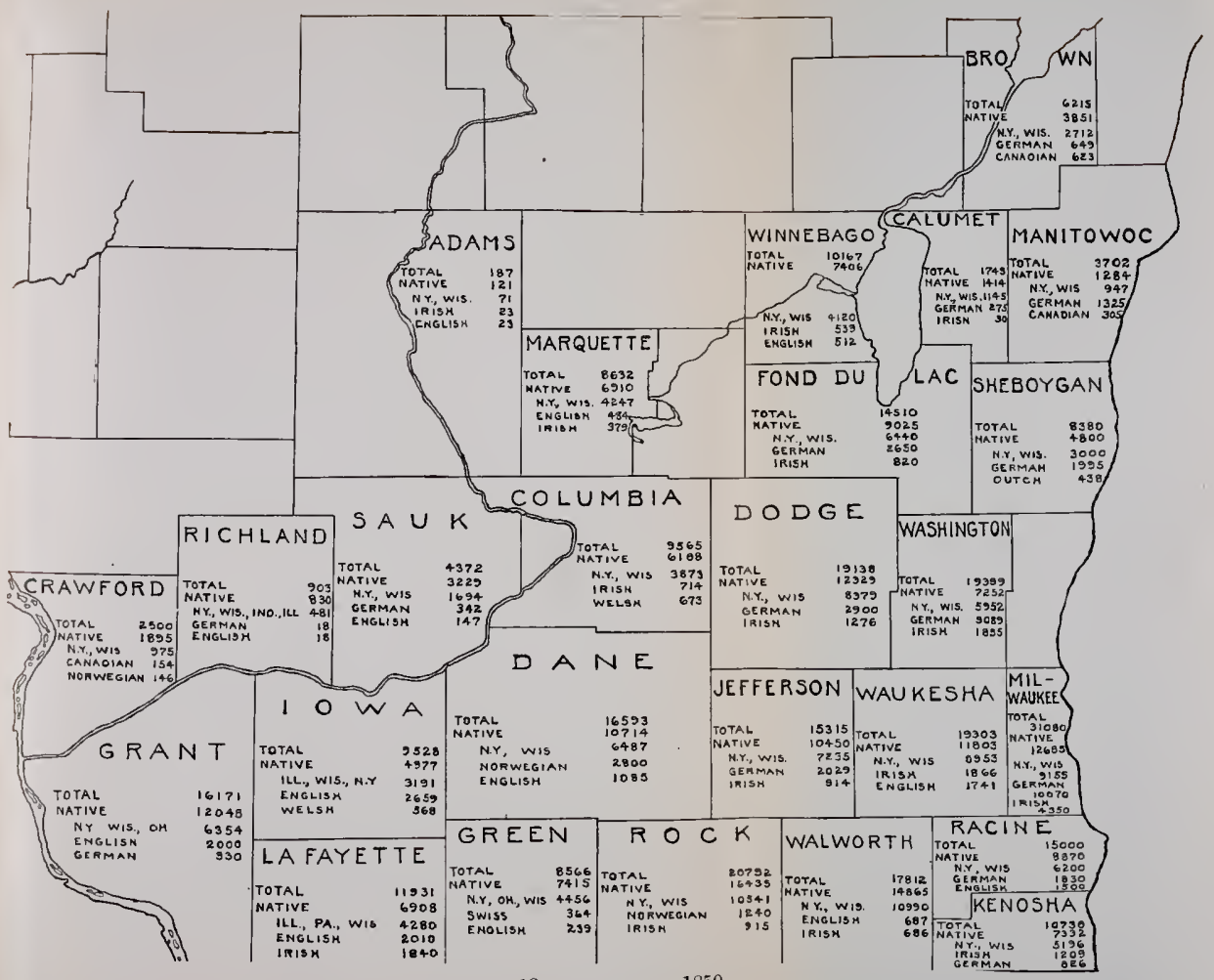

FIC. 13. POPUlatioN, 1850 

tled by the Norwegians so exclusively that in 1850 the census taker found 404 persons of Norwegian birth, to 347 of all other nativities including American, of which there were 161mostly children of the Norwegian families. That town had 6 American families to 140 foreign born, but there were a few. Germans and as many Irish. ${ }^{12}$ We obtain an even more striking result for the town of Pleasant Springs, in Dane County: In a population of 732 the Norwegians numbered 471 and there. were practically no other foreigners. Almost all of these. people were farmers, some being farm laborers and some of the women household servants. In the older settlements they: frequently took up left-over lands, as in the town of Whitewater, where they bought the rough hill lands and the swampy: lands of the southeast part of the town. But they were not deterred from taking open prairie where it was available and openings-the favorite lands-were scarce. In short, the. Norwegians, by their thrift, physical vigor, and enterprise, were destined to become one of the determining elements in the building up of Wisconsin agriculture. Their near relations from Denmark and Sweden, who had only begun to appear by 1850 , have also contributed a share proportioned to: their numbers.

The Irish were not so exclusively agricultural. The county: of Waukesha, where they formed the largest group of foreign born (numbering 1866), had only about 220 farmers of Irish birth. That includes all who are listed as. "farmers" in the census, but the list includes frequently the older sons as well as the owners or lessees of the farms. On the other hand, the single town of Brookfield had in it 238 men of Irish nativity: who were described as laborers on the railroad, doing work as graders. That town had but 22 Irish farmers. The proportion of railway laborers to farmers was different in the other towns, Brookfield happening to be the place where grading was especially active at the census date. Yet, it is clear that most of those who were recent arrivals from Ireland were

1s See table, Wisconsin Domesday Book, Town Studies, I (in press). 
performing wage labor which was usually not agricultural. Of the 22 Irish farmers in Brookfield, at least 14 had been in the country from three to twenty years, as shown by the ages and nativities of their children. Seven had lived for a number of years in Wisconsin, 6 in New York, 1 in Pennsylvania. Taking the 220 Irish farmers in the county as a whole, we find that in 147 cases at least they were well established as Americans by length of residence. How many of the balance were similarly acclimatized we cannot tell; doubtless many of them were. Later censuses reveal the adaptable Irish participating largely in the life of the state. But they are not so distinctively agricultural as the Germans, Swiss, or Norwegians. Probably the circumstance that "assisted-immigration" from Ireland, on account of the potato famine, came just at the time of the rapid development of railway building helps to explain why so large a proportion of the newcomers became railway laborers rather than frontier farmers.

The immigration into Wisconsin from the German states and provinces began, on a large scale, about 1847, though a good many Germans had reached the territory prior to that time. ${ }^{13}$ The first cause of the movement was religious and political rather than economic. Some congregations of Old Lutherans, who were discriminated against at home, were the earliest arrivals. The revolutionary tendencies of the age and their rigorous suppression caused widespread discontent among liberals, especially in the states bordering the Rhine, and the freedom of the American system of government appealed strongly to such men. Wisconsin was just beginning to settle; the climate, soil, and market conditions were favor-

w Kate A. Everest Levi, "Geographical Origin of German Immigration to Wisconsin," in Wis. Hist. Colls., xiv, 341-393. The earliest is said to have been the Old Lutheran congregation from Magdeburg and vicinity, who arrived at Milwaukee in 1839. Some remained there. Most settled the Freistadt colony in Washington County (now Ozaukee) a few miles north of Milwaukee on the Milwaukee River. Later accessions of co-religionists went to Jefferson and Dodge counties, and also to Sheboygan and Manitowoc. In Ozaukee they oceupied the town of Mequon; in Washington, Kirchayn; in Dodge, Lebanon; in Jefferson, Ixonia. Later many went from the earlier settled towns to Sherman, Sheboygan County, and to Cooperstown in Manitowoc. Other north German settlements were formed in Winnebago County and vicinity, in Fond du Lae, and elsewhere. 


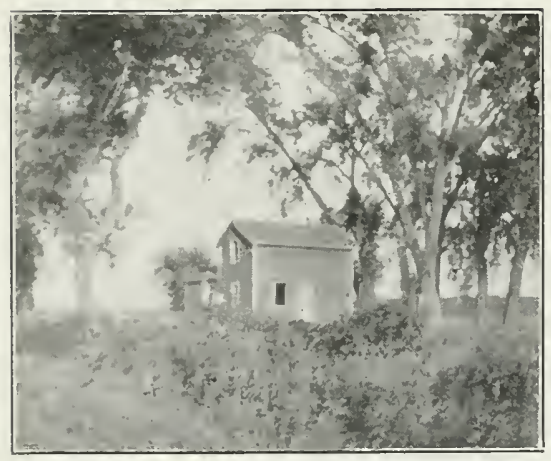

THE ELLING EILSON HOME, JEFHERSON PRAIRIE, 1846

Engraving loaned hy Henry Natesta

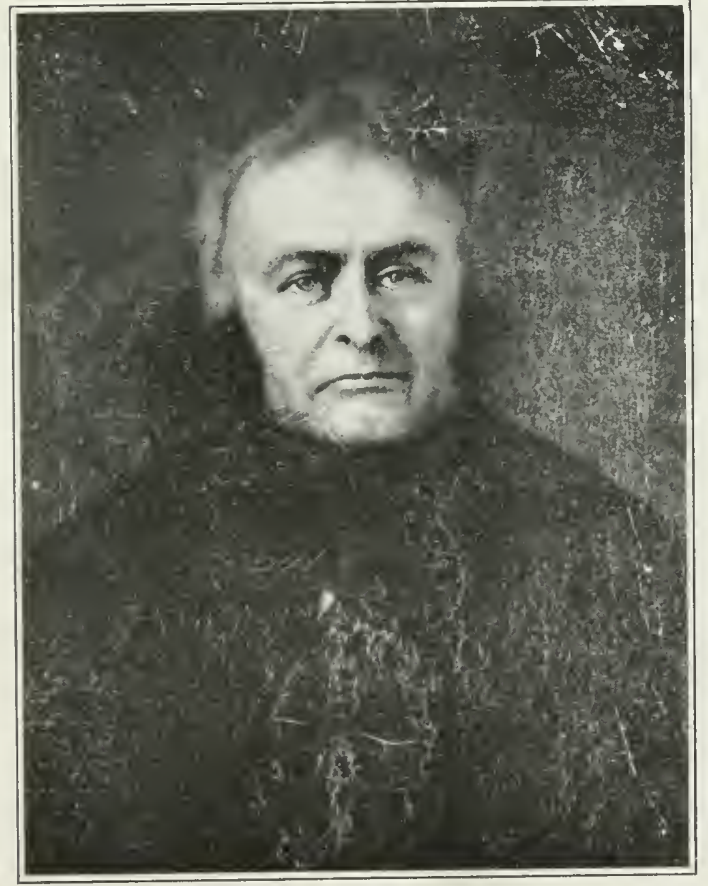

GRIFFITI RICHARDS, WELSH IPIONEER OF 1840

From an oil fainting in fossession of Mrs. Laura Richards, Madison 


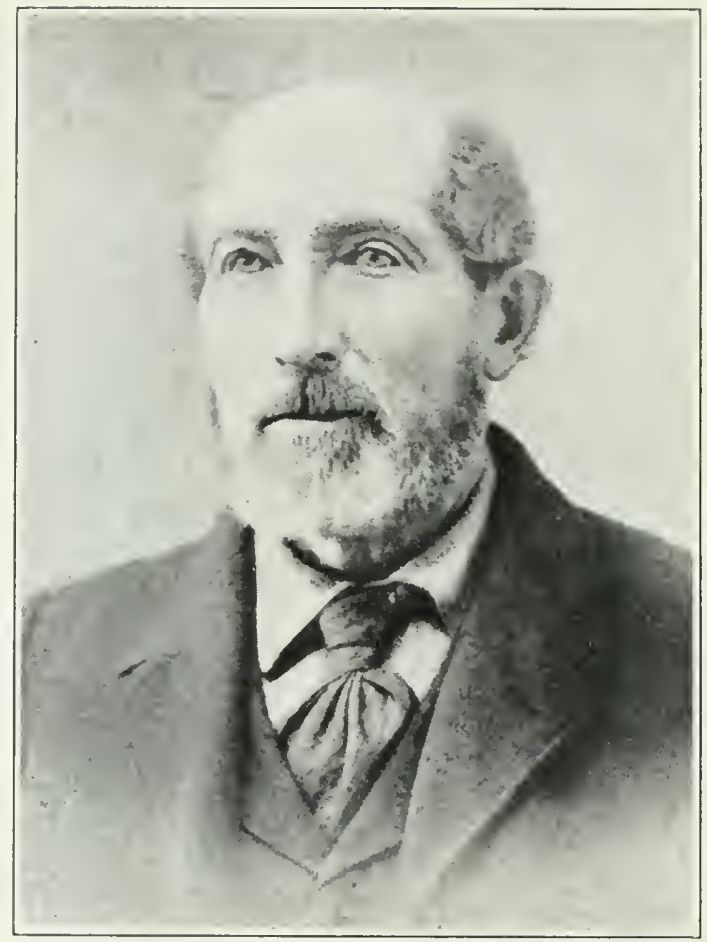

CASPER HENRY MEYER

German pioneer of 1842. Afterwards a prominent farmer of Mequon, Ozankee County 
able; and the state's land policy as well as her political hospitality toward foreigners constituted a strong inducement. The movement once set on foot, large numbers were tempted to embark in it for the sole purpose of bettering their worldly condition, so that the earlier motives of religious and political freedom became subordinate to the economic motive. Books and pamphlets were published in Germany, describing the advantages of Wisconsin for German immigrants. Men of repute from different sections of Germany came over to spy out the land and give direction and guidance to their emigrating countrymen, while state authorities in Wisconsin made it their special care to allure these people. Thus the movement came to be more or less systematized. ${ }^{14}$

The bulk of the Germans who came in the late forties were from south and middle Germany, "Rhenish Prussia," Switzerland, Bavaria, Luxemburg, Baden, and Saxony. ${ }^{15}$ They represented nearly every class and all occupations, though a very large proportion were farmers in their home land and most of them were anxious to acquire lands in the new world. A certain proportion, however, settled in Milwaukee, while the main body swept over the forested area pivoting on Milwaukee as a market, through Milwaukee, Waukesha, Jefferson, Washington, Dodge, and Ozaukee counties. Wishing to be near a market, they at first kept close to the lake ports, many of them buying partly improved farms at the prevailing rates rather than going into the interior to take wild land at government prices. Some settled in Sheboygan and Manitowoc counties, others farther west, in Dane, Sauk, and even Buffalo. Gradually, as transportation improved, they filtered into practically all of the farming areas, and also made up their full quota in the commercial and manufacturing towns. In the earlier censuses, however, we find the vast majority of German immigrants in the country either farming on their own account or working on the farms of others.

\footnotetext{
${ }^{14}$ Kate A. Everest Levi, "How Wisconsin Came by Its Large German Element," in Wis. Hist. Colls., xii, 299-334.

${ }^{15}$ Cf. William Dames, Wie Sieht es in Wiskonsin Aus.
} 
Some of the towns particularly studied from the census of 1850 yield these results: Franklin, in Milwaukee County, had 191 farmers. Of these, 88 were Irish and 55 German. From England came 8, from New York 15, and all other nativities numbered 25. Brookfield, in Waukesha County, had 42 German farmers; New Glarus, in Green County, 66 (GermanSwiss) ; Newton, in Manitowoc, had a large German majority. On the other hand, Mount Pleasant, in Racine County, showed only 16 German farmers; Plymouth, in Rock County, none; Empire, in Fond du Lac County, 3; Norway, Racine County, 24 ; Sugar Creek, Walworth County, none. In other words, the census of 1850 found the Germans located in the forested area of the eastern part of the state. In prairies and openings there were yet only a few.

In 1850 the Welsh, according to the census, had 4319 of their people in Wisconsin. The immigration of Welsh to Wisconsin appears to have begun in 1840, the year following the beginnings of the German and Norwegian immigrations. Griffith Richards and several others came to Mount Pleasant Town, Racine County, in that year, while John Hughes settled in Waukesha County, in the town of Genesee. These families were joined by others, and from the southeast the movement trended northwestward, the attraction always being good lands at government prices. By 1856 the largest colony was in Waukesha County, 680 persons; while Columbia County had the second largest, 676. Racine, the original land of promise, because its free lands were quickly exhausted had only 434. There were settlements in Wimnebago, Fond du Lac, Waushara, and Marquette counties in the north, also in La Crosse and Monroe in the west. A considerable colony of Welsh miners, who soon however became farmers, settled in Iowa and Lafayette counties in the lead region. ${ }^{16}$

${ }^{18}$ Laura J. Phillips, Colonization of Wisconsin by the Welsh, MS. thesis, University of Wisconsin, 1910. Map shows distribution of Welsh. In Racine County the town of Mount Pleasant was the Welsh center; in Waukesha, Genesee, also Ottawa and Delafield; in Jefferson, Ixonia, Watertown, and Emmet; in Columbia, Cambria, Randolph, Scott, Caledonia, Portage, Wyocena, Courtland, Springvale; in Winnebago and Fond du Lac, Nikima and Rosendale; in La Crosse, Bangor; in Monroe, Cataract, and Lafayette. 
The Welsh seem to have arrived mainly as separate families, though some evidence of organization appears in the beginning. But they tended to seek out settlements of their own people, where they could enjoy their own churches, and from older settlements new ones were started. Though the Welsh element was small in numbers, their influence on Wisconsin agriculture was considerable. Among those in Racine County, for example, were some of the most advanced stock breeders in the state. ${ }^{17}$ Their social influence was exhibited most strikingly in their musical organizations. ${ }^{18}$

Unlike the Welsh, who were grouped mainly in a few counties, and in particular towns of those counties, the Scotch were in 1850 widely distributed over the state, though the total number, only 3527, was less than the Welsh. Nearly every town studied intensively had a few Scotch families, but only four counties in the state had more than 300-Waukesha, 453; Rock, 343; Columbia, 339; and Milwaukee, 314. The Scotch were found in the towns as well as in the country. They tended to enter all professions and occupations. In finance Alexander Mitchell, a Scotchman, was for many years the greatest single power in the state. However, probably partly on account of their dispersed condition, few early Wisconsin Scotchmen were found in the political field. Agriculturally they exerted an influence beyond their numbers, for Scotchmen were generally good farmers as well as tireless workers. John Muir, in The Story of My Boyhood and Youth, presents a faithful though by no means agreeable picture of the unending toil endured on his father's pioneer farm in Marquette. County. The leading shorthorn breeder of the Northwest during the seventies was George Murray, a Scotchman of Racine; and many others could be named who by their intelli-

${ }^{17}$ Richard Richards, for example, son of the original immigrant Griffith Richards, was a foremost breeder of shorthorn cattle, Berkshire pigs, and thoroughbred horses. See Mount Pleasant Town. Charles H. Williams of Sauk County, another prominent shorthorn breeder, was of Welsh origin, but several generations back.

${ }^{23}$ The Welsh Musical Union was formed in 1865, with the objects of promoting the study of church music, encouraging composition and publication, and giving musical festivals. 
gence, skill, and enterprise advanced the interests of scientific agriculture in the state.

We have already explained the preponderance of English among the foreign elements in the three lead producing counties-Iowa, Grant, and Lafayette-which together had 6665, or more than one-third of the whole number of natives of England in the state. These were largely miners and smelters who became farmers in due time. Among the purely agricultural counties the largest English element was in Waukesha, 1741; the second largest in Racine, 1498; and the third in Dane, 1085. There were also goodly numbers in Kenosha, Walworth, Rock, Jefferson, and Fond du Lac counties. Other counties had fewer, but all had some.

Like the Scotch, the English were usually widely dispersed, as individuals or families, among the prevailingly American population, the identity of language and similarity of traditions operating to make both the English and the Scotch organic elements in the American social order. The Welsh were less easily assimilable, and the Cornish miners, as a distinctive occupational class, also remained for a time somewhat aloof from the Americans.

Some efforts were made to colonize English people in Wisconsin. One such led to a settlement in Dane County, at Mazomanie, under the auspices of the British Temperance Emigration Society. The settlers were largely artizans from Liverpool. Agents of the society came out in advance, bought land, erected log houses, and in other ways prepared for the coming of the emigrant families. This settlement was established in the years 1843-50.19 A kind of offshoot, by suggestion, of the Dane County movement was the English settlement formed about the same time near Fox River in Racine County. Most of those people, also, were artizans. ${ }^{20}$ The decade of the forties was in Great Britain a time of unrest and discouragement

\footnotetext{
${ }^{10}$ See William Kittle, The History of the Township and Village of Mazomanie (Madison, Wis., 1900).

${ }^{20}$ One of their leaders was Edwin Bottomley, whose letters and papers are published in Wis. Hist. Colls., xxv.
} 
for artizans, as well as for the agricultural laborers, and the English emigration of the period contained a large proportion of each, together with families possessed of more means who came from both country and town. An Owenite ${ }^{21}$ community was started in Waukesha County, town of Genesee. A larger English settlement occupied most of the town of Lisbon in the same county. Probably the selection, in 1842, by the Episcopal church, of the Nashotah lakes as the site of their theological institution, and the establishment of the bishop's residence near by in 1846, had some influence in attracting English settlers to that section of Wisconsin and helped to make Waukesha County, in the early days, the banner English county of the state.

In the general summary we have spoken of the natives of Canada (8277) as non-English, and it is probably correct to regard most of them as French, particularly those who belong to the fur trade tradition. Yet, there must have been a good many English from Canada, also Scotch and possibly Irish. Brown and Winnebago counties together had more than 1000 Canadians, Dodge and Fond du Lac had 1300, while Crawford and Grant had about 400. The farming counties of the southeast all had respectable numbers of them.

The Dutch (from Holland) were a small element, given incorrectly in the census summary at 1157 all told. Most of them, some 1300, were in the three counties of Milwaukee, Sheboygan, and Brown. All the rest of the counties contained but 300 , of which Fond du Lac had one-half. ${ }^{22}$

The major American element in the population was the Northeasterners. As already pointed out, the Americans were in the majority in all counties save three-Manitowoc, Milwaukee, and Washington-and in 21 counties the New Yorkers, added to the natives of Wisconsin, made up a majority of the Americans. It requires no argument to show

\footnotetext{
${ }^{21}$ A community on the communistic basis, following the principles embodied by Robert Dale Owen in his Indiana colony at New Harmony.

zC. A. Verwyst, "Reminiscences of a Pioneer Missionary," Wisconsin Historical Society, Proceedings, 1916, 148-165.
} 
that natives of Wisconsin were in 1850 prevailingly in the stages of childhood and youth. So that, practically, affairs were in control of the New Yorkers supported by other eastern people and by those from Ohio and the northwestern states. Vermonter's were about one-sixth as numerous as New Yorkers; other New Englanders, taken together, made up about as many as the Vermonters; while Pennsylvanians, Jerseyites, etc. were approximately as many more. In other words, wherever there were six New Yorkers there was apt to be another middle states man, a Vermonter, another New Englander, and an Ohioan, who also in most cases, like the bulk of the New Yorkers, was probably of New England origin.

The two states of Vermont and New York are so peculiarly the "cradle" of Wisconsin's society in its early stages, with all that fact implies as respects her institutions agriculturally and otherwise, that some special study of those states is called for by way of background: And, first, it may be said that it was the northern and western counties of New York and the western counties of Vermont which sent the great bulk of the immigrants into the new commonwealth growing up tributary to Lake Michigan. It was these western counties, in the two states, which by reason of their stage of development were among all eastern communities in the best situation to release population for colonizing purposes at the time Wisconsin was in the making.

Vermont was the earlier of the two regions to be settled, but its actual development as an agricultural community was slower than that of western New York, so that the canal building epoch found them similarly situated though the opportunity for rapid progress in the fine, tillable lands of the Empire State was superior to that in the rough, much divided and dissected, though not infertile, area east of Lake Champlain. Until the canal came, both regions had been nearly but not quite cut off from markets. The western Vermonters could reach the Hudson by making the long haul to Albany or Troy; 


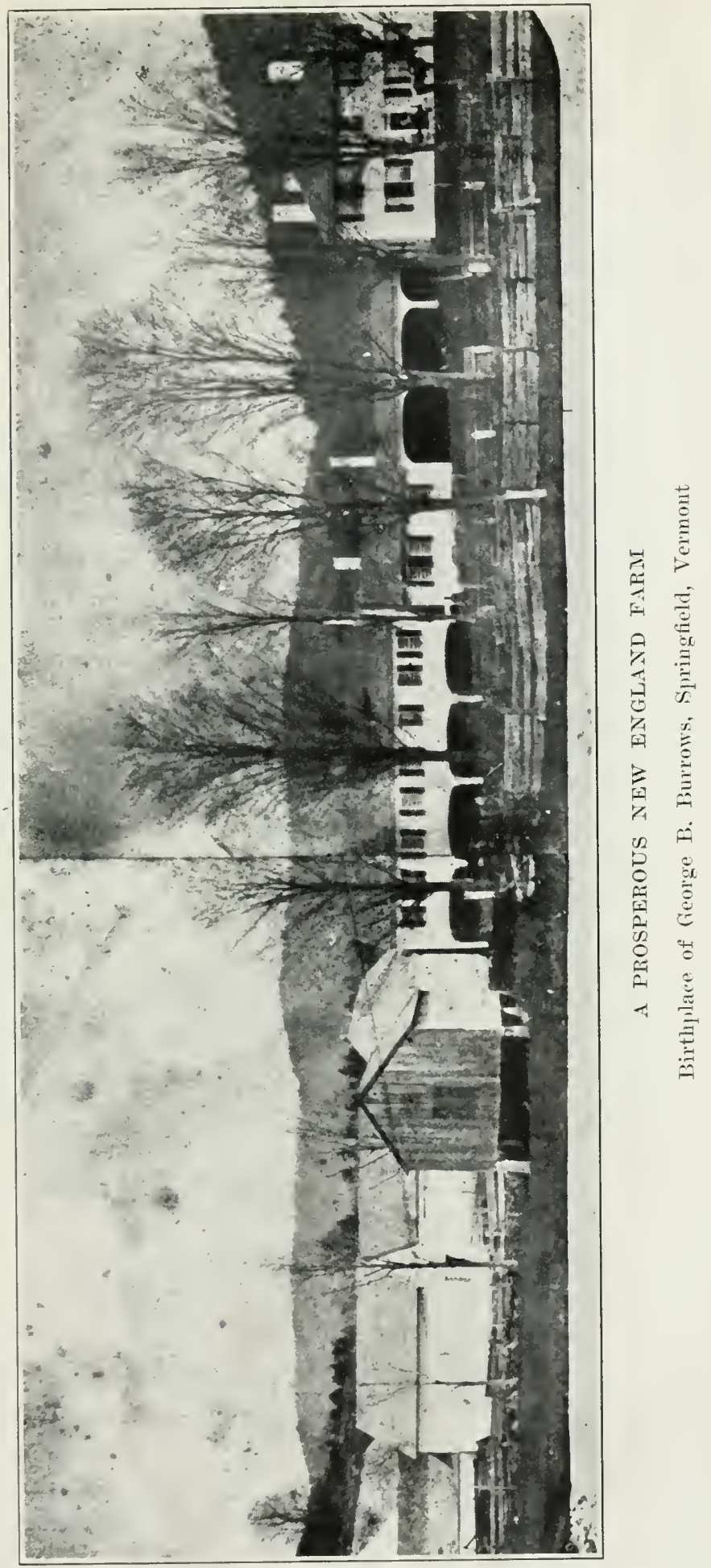




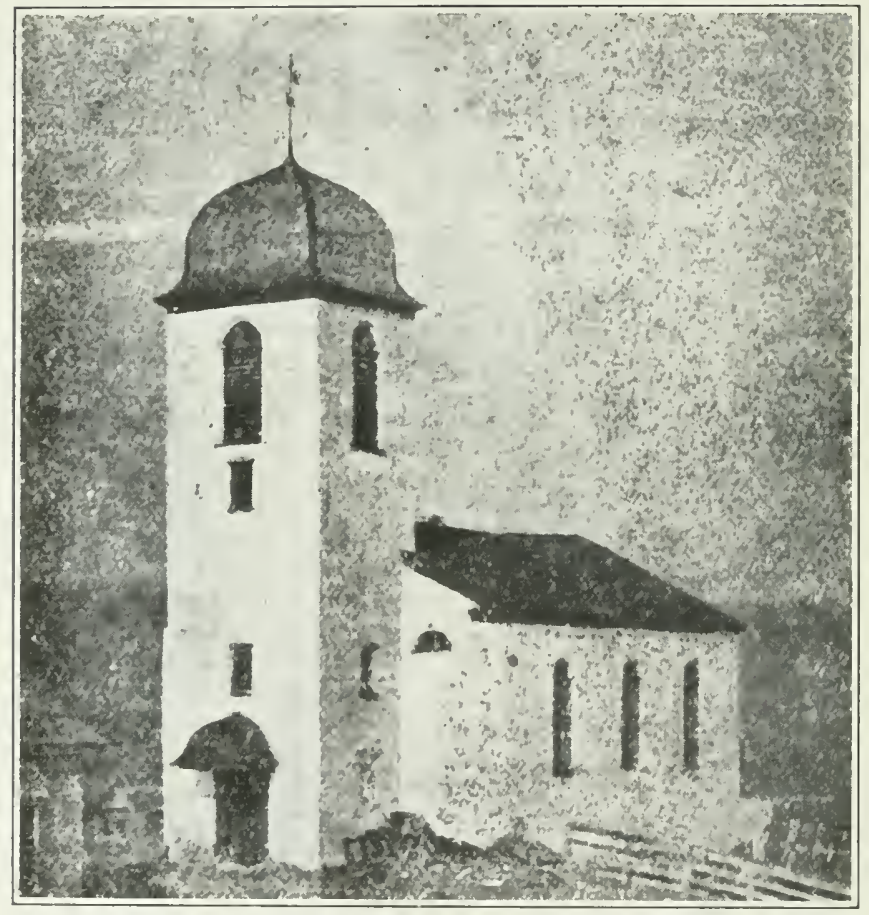

OLD SWISS CHURCH, NEW GLARUS, WISCONSIN 
the New Yorkers could haul to the Mohawk, or flat-boat their grain, flour, and pork down the Susquehanna, the Delaware, or the Allegheny River. The process of marketing, by all these expedients, was uncertain and expensive. The remedy was canals, and the great New York project for canal building embraced as one feature the construction of a canal from Albany to Whitehall, where it communicated with the farextended waters of Lake Champlain. The other important feature was the Erie Canal. One opened a line of transportation from the central portions of western New York, connect. ing with the Hudson; the other made a convenient outlet for all that portion of Vermont which was within hauling distance of the numerous ports on Lake Champlain. That meant practically the greater part of Vermont, west of the ridge of the Green Mountains-at least the five western counties of Franklin, Chittenden, Addison, Rutland, and Bennington. A glance at the map (Fig, 14) will show that Lake Champlain is itself a natural canal of extraordinary length. With the artificial link uniting it with the Hudson, it was bound to prove of infinite economic importance to both New York and Vermont.

In consequence of the opening, about 1820, of this new line of transportation, agriculture in Vermont underwent a rapid and radical transformation. In the time before the canal the farm was a self-sufficing unit, the family producing in field and household almost everything required for its sustenance. Little was raised which could be sold for cash, except cattle. These, purchased by the drovers, were driven to the New York market or to Boston. An annual trip by the farmer to Albany with a load of dairy products, maple sugar, or pork was the only other means of furnishing the family with those absolutely essential supplies which could be secured only from outside.

The farm homes were scattered widely, not only through the valleys but over the sides of steep hills and mountains and even on their summits. In building homes the pioneers had little reference to ease of communication with the outside 


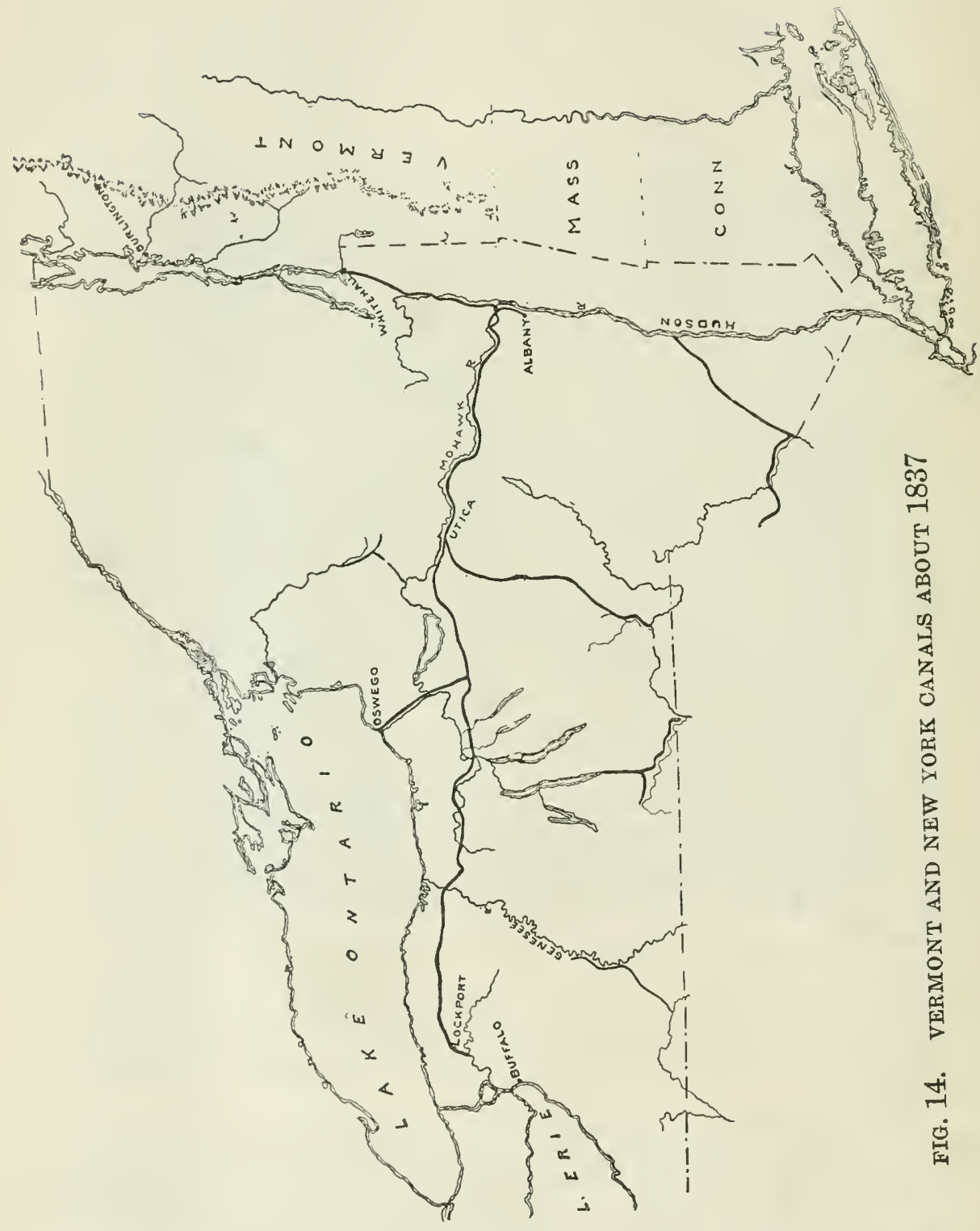


world, a trip out being only an occasional event. They built wherever the land seemed productive and where the labor of clearing was not too great. One of the most impressive social effects of the opening of canal transportation, as noticed by Vermont historians, was the way the inhabitants deserted the highlands, leaving vacant houses scattered over the mountains. The hill roads were closed and new ones opened on the lower grounds, making a system of highways leading to the shipping points. At the same time the inhabitants were concentrated in the mountain valleys, along the river courses, and near the long shore line of Lake Champlain.

That change illustrates the change which was occurring in Vermont agriculture. Wheat raising was no longer as profitable as it had been. On the other hand, with water transportation dairy products, pork, mutton, potatoes, and onions could be shipped regularly and cheaply to the New York market. The rich valley lands which grew hay, corn, and root crops rose rapidly in value. The hill lands also advanced in price, but these were now worth decidedly more for pasturage than for cultivation. They supplied much of the summer feed for cows and young stock, for horses, and especially for the fine wooled merino sheep, in the rearing of which Vermont farmers were becoming famous. Farmers whose lands were mostly hill lands could not take full advantage of the new agricultural opportunity. Small farmers were handicapped for livestock and dairy farming as compared with those having larger holdings and the proper varieties of land within the same farm. Under the advancing prices, however, it was a temptation to sell the farms which for any reason seemed unsatisfactory. Also, those farmers who did not care to readjust their agriculture to the new conditions were now able to sell out readily, go west, and raise wheat along with those who were eager to get away because their farms were ill adapted to a livestock economy.

That there was much consolidating and remodeling of the farms is shown not only by the vacant, decaying farmhouses 
on the hills and the new ones in the valleys, but also by the fact that the agricultural population in these counties actually decreased between 1830 and 1850. Besides, the testimony of writers in the forties is that many of the dairy farms were relatively large, supporting 40 or more cows, while flocks of 100 to 200 sheep were extremely common. ${ }^{23}$ The whole point is, that when farming became a business instead of merely a way of getting a primitive living, it soon shifted to the basis of a livestock economy, which requires for success-at least under conditions prevailing at that time-a considerable amount of land. ${ }^{24}$

The facts just stated give the reasons for the rapid emigration of Vermonters to the West during the period of readjustment following the opening of the canal. A similar situation was to be found in western New York at the same period. New York counties, too, were by 1840 losing rural population. The local historians bewail the fact that, but for the rapid growth of towns and villages their counties would soon be in serious distress from the loss of so mally of their inhabitants. They explain that the opening of new markets to their farmers, as branch canals were completed from time to time, changed the character of farming from the earlier wheat growing basis to the livestock and dairying basis, which required more land. The larger farmers had in many cases bought out the small farmers, "to enlarge their own fields. The latter class emigrated to the west where land is cheap." 225

${ }^{2 y}$ See Hosea Beckley, History of Vermont (Brattleboro, Vt., 1846), especially p. 27, 58-60, 140-141.

${ }^{24}$ With the soiling system, the silo, and high-producing dairy cows the presentday farmer can make a success of dairying on a small farm.

${ }^{25}$ Hiram C. Clark, History of Chenango County (Norwich, N. Y., 1850), 73. The same testimony comes from Emory F. Warren, Sketehes of the History of Chautauque County (Jamestown, N. Y., 1846), 133. Speaking of the census of 1840, which showed an increase for the county of only 2672 in five years, he says: "The emigration to the west from this county has been large, and it is believed much larger than the accession to our numbers in agricultural sections. The pursuits of the agricultural population lave tended to diminish rather than increase their numbers. The accumulation of real estate in the hands of those engaged in grazing, has materially diminished the number of those who held small tracts of land, while the latter have sought wider, and more fertile fields in the valley of the Mississippi.", 


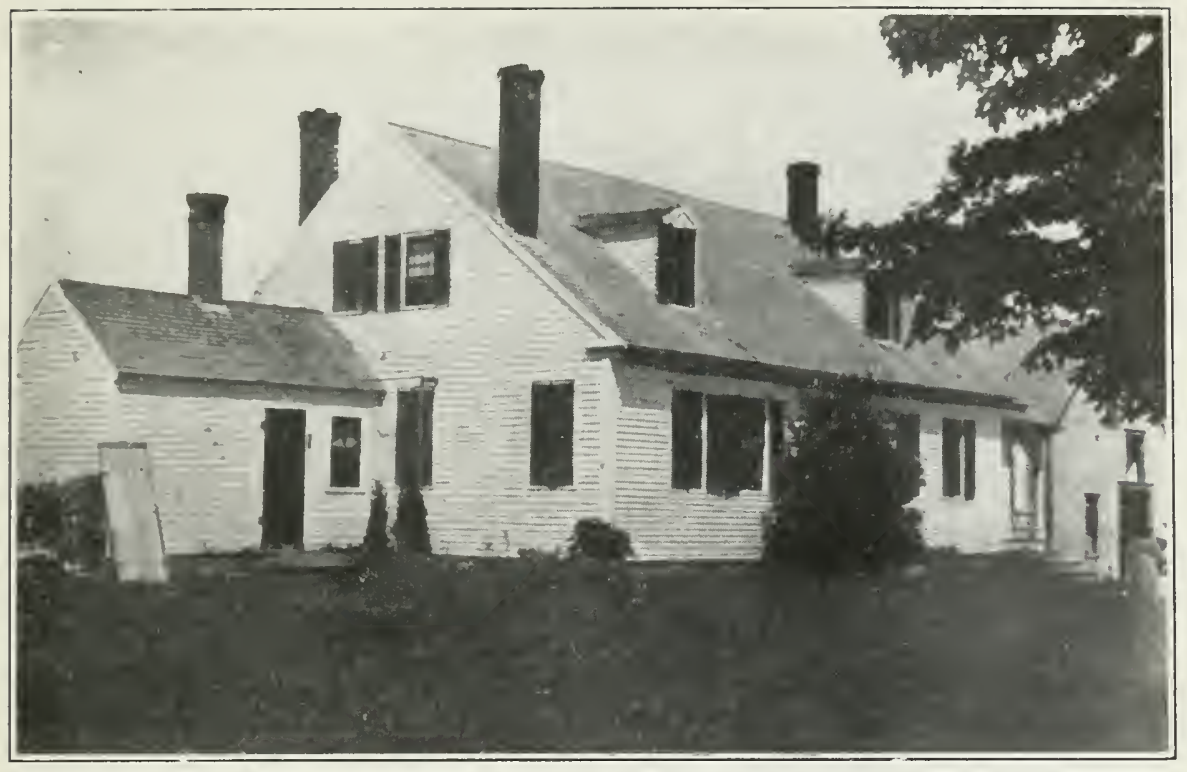

FARM IIOME AT EAST WINTIJROP, MAINE

Built before 1819

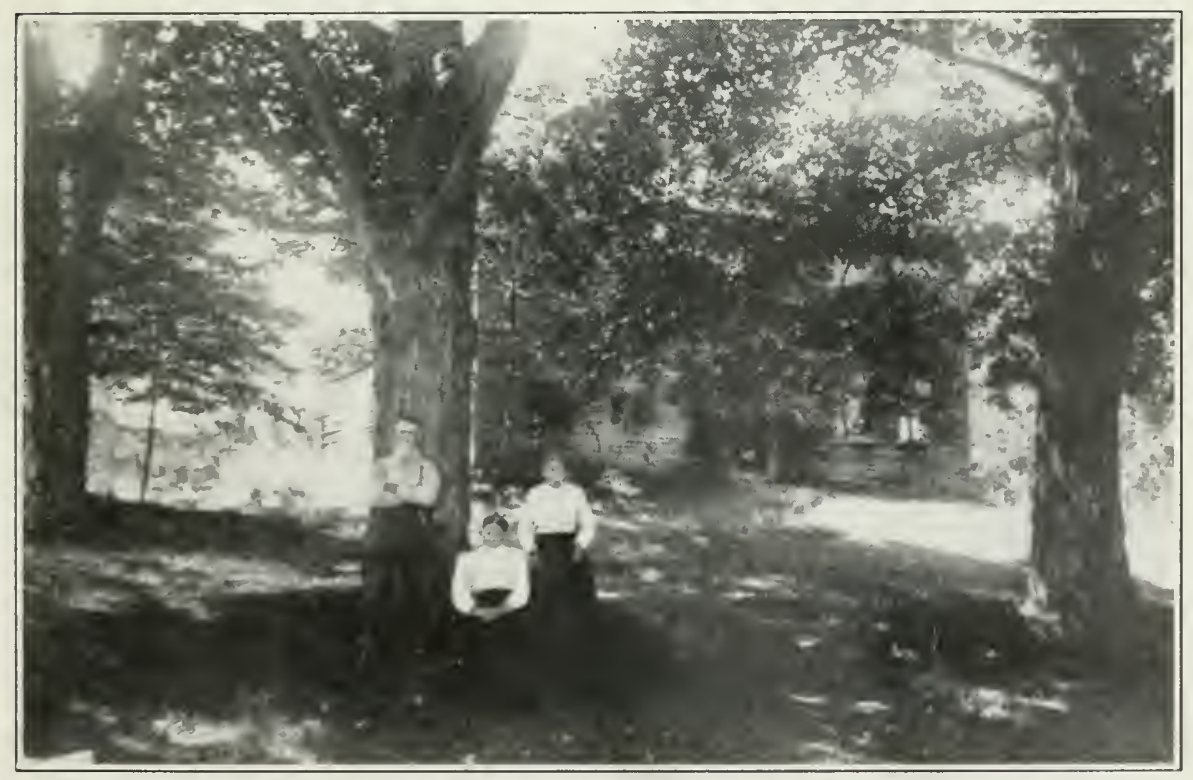

FARM HOME A'T HLOOMFIELD, CONNECTICUT, NEAR HARTFORD

Built in the eighteenth century 


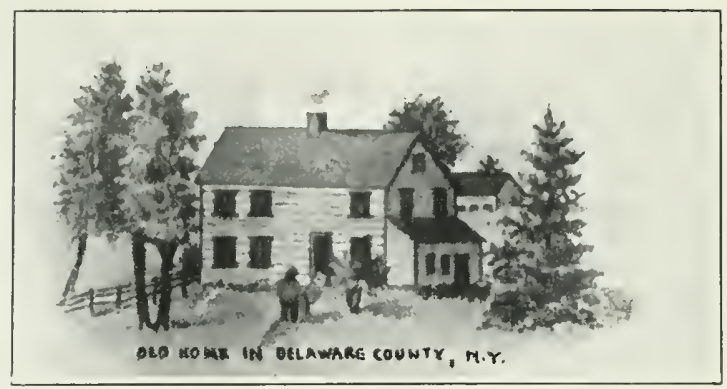

OLD IIOME IX DEXAWARE COUNTY, XEW YORK

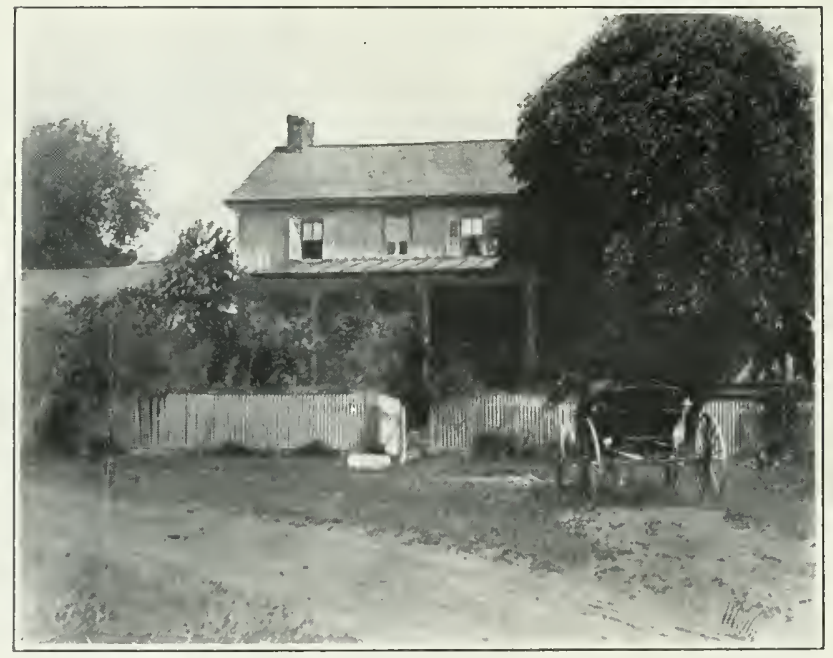

A IPXXSYLVANIA FALAL IIOJE

House built before 1:15 
Railway building followed canal building and stimulated improvement in a revolutionary manner for a number of years. ${ }^{26}$

Doubtless, also, the ease with which farms could be made in the region of prairies and openings had its influence in inducing farmers to part with lands only half cleared, and go west rather than challenge the heavy task of clearing the balance. This is said to have been one chief influence affecting emigration from Ohio, which likewise yielded many valuable farmers to early Wisconsin, and conditions in New York were nearly the same as in Ohio. ${ }^{27}$

Wisconsin, at the moment, was a favored western land for these New York and Vermont people, as well as for other Easterners and emigrants from Ohio. ${ }^{28}$ Lake Michigan was quite as advantageous for commerce, save for the greater length of shipping route, as Lake Champlain or the Grand Canal, while the destination of freight consigned to vessels at her ports was the same as for that consigned to the canal at Whitehall or at Utica.

If one could recover the everyday thoughts of these people, to whom canal transportation, the Erie Canal, the Great Lakes system, and the far western lands along the Great Lakes were, of course, daily topics of conversation, we would probably discover that the generation then on the stage in western Vermont and New York were better prepared, psychologically, for making new homes on the distant shores of Lake Michigan than Connecticut people of fifty years earlier had been for moving into western New York, or into Vermont itself. With cheap water transportation assured, the excellence of the lands in Wisconsin or Illinois or Michigan and the chance to secure farms embracing in due proportions prairie, mead-

${ }^{20}$ See article by Rufus King, in Milwaulee Sentinel, Aug. 20, 1851, entitled "The New York and Erie Railroad." He shows how the comitry hetween Dunkirk and Elmira was changing (new houses building, new lands brought under improvement, new plank roads begun, etc.) as a result of the opening of the railroad.

${ }^{27}$ See Sir James Caird, Prairie Farming in America (New York, 1859), 119. Ohio had lost 140,000 people in seven years, from 1850 to 1857 . Small farmers were selling to larger farmers and going west to the prairies.

${ }^{23}$ R. L. Allen, in American Agriculturist, 1843, 236-287. 
ow, and woodland ${ }^{29}$ constituted a lure which was overpowering. The sale of a small farm in the home land, at prevailing prices, would enable the emigrant to buy a generous quantity of government land or speculator land, erect buildings and fences, and farm on a larger scale than formerly. ${ }^{30}$ Those who preferred wheat raising to general farming-and they were legion-found on the prairies and openings of the West, near the lake ports, an unrivaled opportunity. So they came, these intelligent, moral, industrious, and enterprising Easterners. They overran the southeastern counties of Wisconsin in short order, picking the finest lands in the most ideal combinations, also looking for honest speculations in mill sites and town sites. They came to Wisconsin in such numbers that, in the short space of fifteen years, our state had almost as large a total population as Vermont. ${ }^{31}$

$\approx$ Woodland in western New York was quite as valuable as good farm land. See John Fowler, Journal of a Tour in the State of New York, 1830 (London, 1831).

${ }^{\circ}$ The Vermont papers in 1837 contain numerous advertisements of farms for sale. Also, a through packet line of canal boats was put on to carry westward bound passengers from the ports on Lake Champlain to Buffalo. These boats moved forward day and night, reaching Buffalo in six days from Vergennes.

"Wisconsin, in 1850, had 305,391; Vermont, by the same census, had 314,120. 


\section{CHAPTER IV}

\section{PIONEER CONDITIONS}

A young man from the Mohawk valley, in New York, arrived in Wisconsin in the summer of 1840 , and on his numerous jaunts about the Territory during that and succeeding years observed widely as well as closely the conditions prevailing in different sections of the country. In the beautifully written diary which he kept during those years we have the record of his impressions of places and things. He says: "Frequently was the oft-told story of my grandparents brought to mind as I beheld here their habits \& customs yet extant, \& their mode of living again adopted and made agreeable by circumstances; as I saw the humble log-houses and huge fire-places, out-door ovens and earth-covered cellars gathered in small groups beside the winding highway of the adventurous pioneer." "1

This quotation gives us at once the lineage of early Wisconsin civilization (which derived from New England) and the time interval by which, as it appeared to this writer, pioneer conditions in Wisconsin in the early forties were separated from those which prevailed at that time in the most advanced sections of the Northeast. The diarist's grandparents belonged to the era of Washington's presidency. If we had a clear picture of the external conditions of life in western Massachusetts in the stirring days of Shays's rebellion, or in Vermont, New Hampshire, and New York about the same time, we should also have a fairly adequate notion of what life was in Wisconsin Territory between 1835 and 1850. Some such picture we may obtain by reading, for example, Timothy Dwight's Travels in New England and New York, executed mainly between 1795 and 1800. Dr. Dwight, when he drove his

${ }^{2}$ Frederick J. Starin, MS. Diary. Lent to this Society by his daughter, Mrs. Imogene Starin Birge of Whitewater, Wisconsin. The publication of this diary was begun in the Wis. Mag. of Hist., September, 1922. 
horse and light two-wheeled rehicle north into upper New Hampshire, experienced the distressing "corduroy" road. $\mathrm{He}$ also saw by the wayside the round-log, "chinked and mudded" houses standing in fields partially cleared but still encumbered by stumps and girdled trees. These were the symbols of the actual frontier. He had but just passed decent hewed-log houses and fields fully cleared, back of which again, in that "land of steady habits" from which he set out, were the tidy villages of older New England, their white-painted cottages adorned with green window shutters, the inevitable "village green" flanked by town-house, church, and school, and in the distance smiling, well tilled fields, rich pastures, and sheltering wood lots.

If we allow fifteen years as the period during which the greater part of southern Wisconsin was in the pioneer stage of development, we may discover in that period most of those variations in the artificial surroundings of the people which Dwight found in New England and New York fifty years earlier. There were the crude beginnings of agriculture on the part of those who, devoid of financial means, relied almost solely on their personal strength and fortitude to make a living from timber and soil. Suited to this class was the rough cabin of unhewn logs, covered with "shakes," chinked, and daubed with mud, floored with "puncheons," and fitted with a few awkward homemade stools and benches, a board across the flour barrel and the pork barrel for a table, with beds of leaves or of straw. ${ }^{2}$ Those, however, who were accustomed to good homes in the East, or in Europe, and who had the means to do so, promptly erected more pretentious houses. These might be made of dressed logs, neatly pointed up with mortar, and fitted with saved-board floors and doors, glass windows, and decent furniture. If lumber in quantity was procurable, such settlers delayed scarcely a year or two, or at most a few

\footnotetext{
2 Such rude shelters were eustomarily erected also by the abler sort of clain takers when they came out to take their claims and before buying their lands and bringing their families.
} 


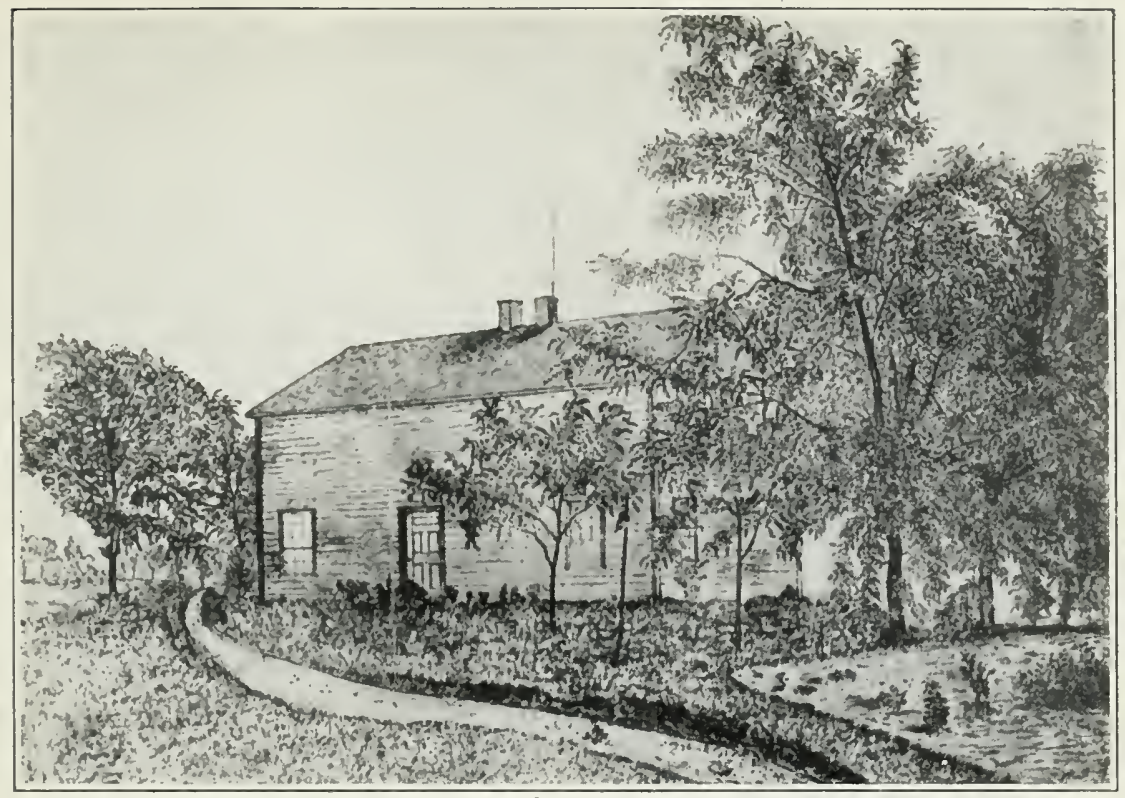

TIIE FIRST WISCONSIN HOME OF JOIN MUIR, 1849

From his Story of My Boylhond and Fouth. By courtesy of the Houghton Mifflin Company

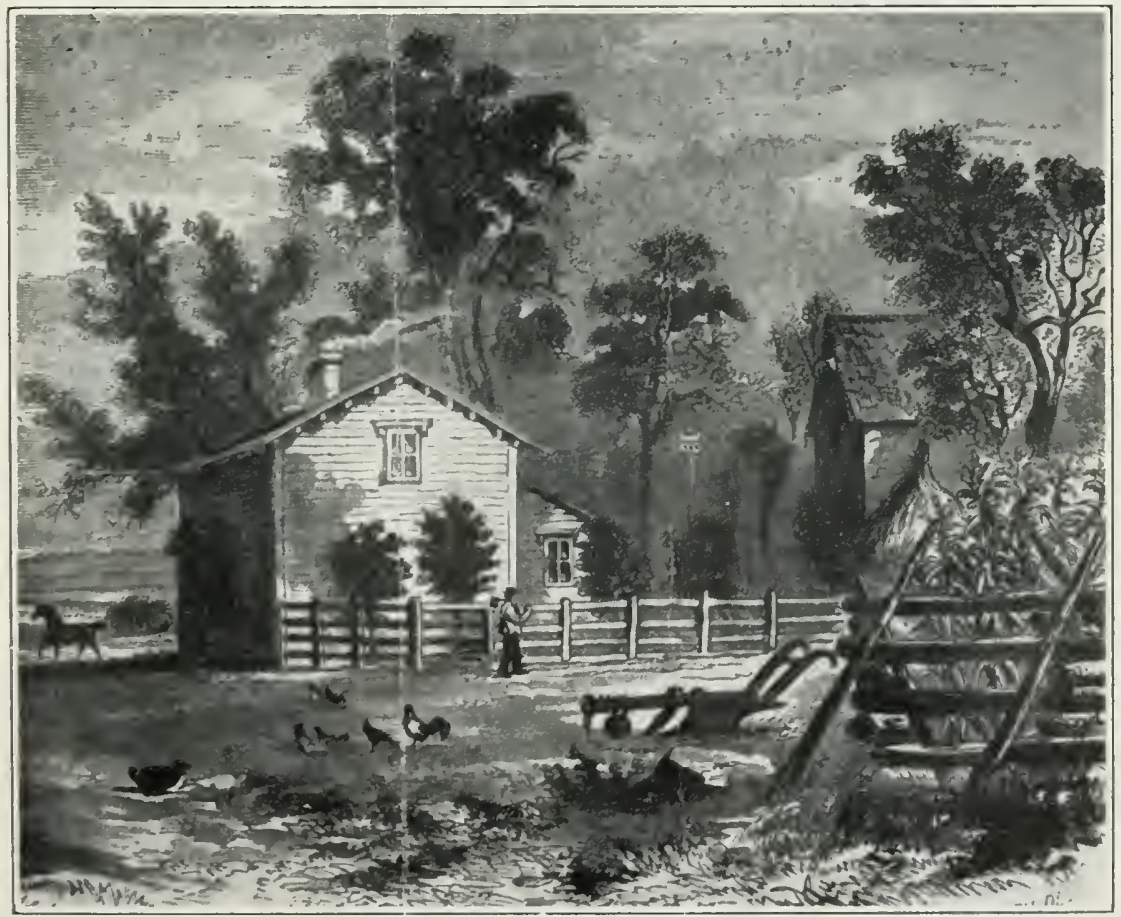

A TYIPCAL PRAIRIF FAlBA HOME, 1850 


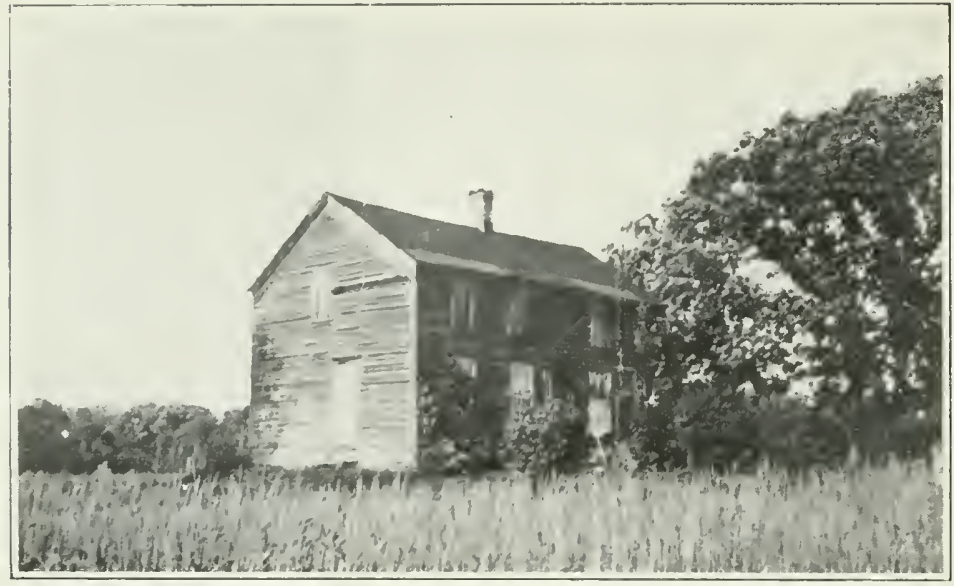

HOIE OF WILATAI WILOX ON TIE LEMONWEIR, JNEAT COUNTY

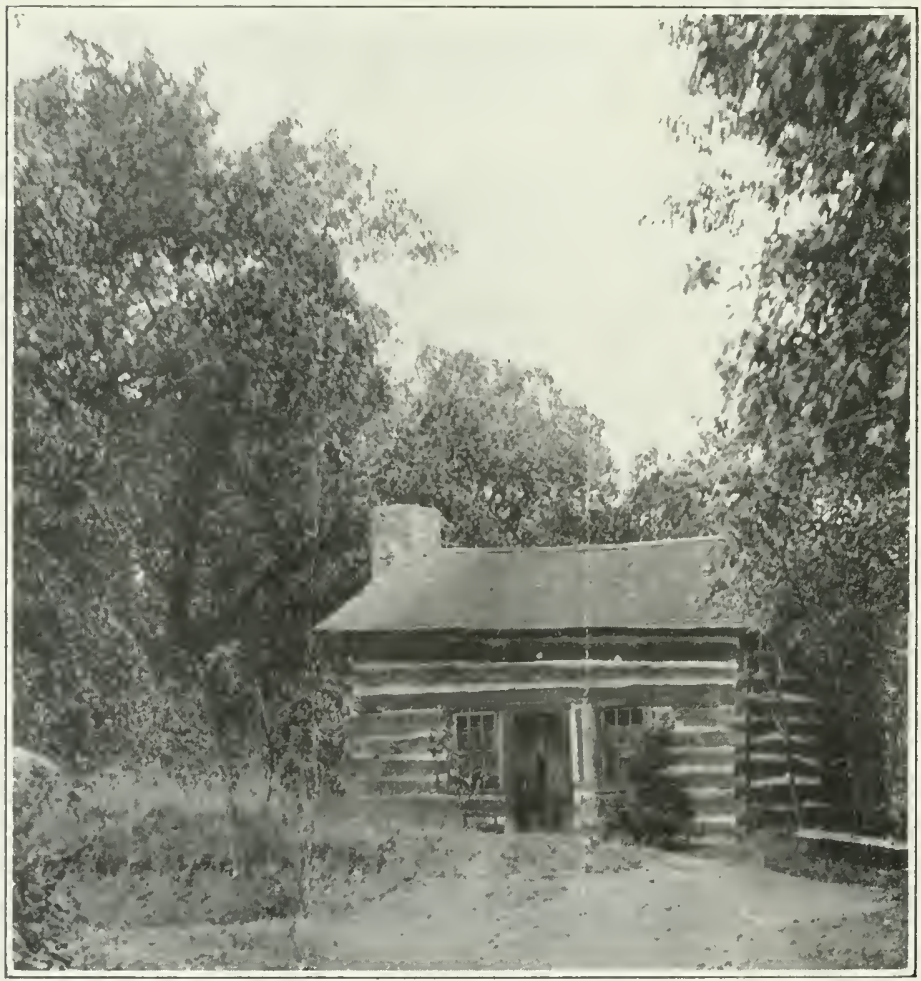

TITE FIRST HOUSE IN WHITEWATER (IECONSTIRCTION)

On State Normal School groumrs 
years, before building comfortable frame houses or, in some cases, houses of brick or of stone.

There were frame buildings in Racine and Kenosha counties in 1836, in Waukesha County in 1838. The town of Whitewater, Walworth County, received its first settlers in 1836. These were the claim makers, who came without their families and erected only such shelters as were indispensable. The next year and the two years which followed saw much building of respectable log houses, barns, and rail fences. Nearly all settlers in southeastern Wisconsin were compelled to wait till 1839 before they could buy at the Milwaukee land office the lands they had claimed and improved. Naturally, building was apt to be of a temporary character until land titles were secured. Thereafter, frame structures went up apace. The first of these at Whitewater was the gristmill, raised in June, 1839. The next was a frame barn, raised in June, 1840. Then followed, the same year, farmhouses, a house for a tavern, etc. Some of these buildings had frames of heavy hewed timbers and were covered with sawed pine lumber. Frederick Starin, who records the raising of the barn referred to, on June 18, 1840 , noted "several frame houses" on Heart Prairie at the same time. He also saw other's in Walworth County, though as yet they were scattering.

The earliest frame buildings, both at Whitewater and elsewhere in the southeast, ${ }^{3}$ were usually constructed out of lumber sawed in little neighboring mills. Lumber being a prime necessity to a new community, the numerons mill sites usually had sawmills established upon them first of all. Later, gristmills were erected on some of them. The local sawmills used oak, sometimes walnut, also basswood, elm, and maple-whatever kinds of timber grew near by or were brought in by the settlers to be sawed.

These mills did not remain long in the prairie and hardwood sections. For, about the date of the earliest settlements in those regions, Chicago companies began lumbering in the con-

Except Kenosha, where lumber is said to have been received from Sheboygan before the end of the year 1835 . See Wis. Hist. Colls., ii, 464. 
venient pinery on the shore of Lake Michigan in Sheboygan and Manitowoc counties. ${ }^{4}$ From those places good pine lumber was soon supplied to all the lake ports-Milwaukee, Racine, and Kenosha-where settlers bought it when marketing their wheat to haul back to their farms by way of return loads. By the year 1844, it is said, even a community as far from the lake as Whitewater bought pine lumber freely at Milwaukee, in preference to using the cheaper product of local mills. ${ }^{5}$ Even prior to that time, the prairie farmers near Racine and Kenosha were using pine lumber from the northern mills, which sold very cheaply, for building houses, barns, and even fences. The farmers in the heavy timber had motives for patronizing the local mills much longer, but these farmers, having a superabundance of timber, were very apt to use unsawed logs for building. Sawmills were early opened also in the pineries on Wisconsin and Chippewa rivers, from which lumber was supplied to all settlements along the Wisconsin and the Mississippi. Much of the product of these mills, after a few years, was rafted down to Iowa, Illinois, and Missouri, so abundant did pine lumber become. The Wisconsin settlers, being nearer, secured it at the cheaper rates. There is no doubt that the combination of farming with lumbering in the industrial history of early Wisconsin was fruitful in many ways, among them in getting the farming population out of the first rough shelter of logs within a shorter time than must be allotted to the "log-house era" of primitive society in other wooded sections of America.

The first frame houses were built on the prairies, as one would expect. But in southeastern and southern Wisconsin the prairies were so intermingled with the oak openings and the denser woods that the prairie farmers, setting the style, were quickly followed by the neighbors who might have built of logs. On the larger prairies, like that of La Crosse,

\footnotetext{
"The mill at Sheboygan was ready for business in the spring of 1835 . The Manitowoc lumber business began about two years later. John Lawe's mill at Two Rivers seems to have been built even earlier than the above-perhaps in 1833.

- But pine lumber from Milwaukee was used at Whitewater earlier than 1844. Letter of Julius C. Birge, dated Mar. 13, 1922.
} 
even the earliest houses, or "claim shanties," were built of pine lumber, which was much cheaper than logs would have been. ${ }^{6}$ Some of the settlers in these later occupied regions went from the older Wisconsin counties, and often built good, substantial frame houses at once. This suggests that decent, comfortable houses were probably the rule by about 1850 in the older communities wherever the lands were not heavily wooded and where a market for grain was within reach. For, here as elsewhere, one's habitation was usually an indication of his prosperity or the reverse. ${ }^{7}$

In the matter of furniture, those who came to Wisconsin from Ohio, Pennsylvania, or western New York by team were able to bring only a very few articles with them. In many cases, however, household goods were shipped by canal and lake to one of the ports, and hauled to the destination by team. Many stories are told of the difficulties encountered in carrying household goods from Racine or Milwaukee or elsewhere, by ox team, to Janesville, Whitewater, Aztalan, and other interior points, over miry wood roads, through marshes, and across swollen unbridged streams. The frequent instances of steamboats carrying such freight past the Wisconsin port for which it was booked, and unloading it at Chicago, caused sharp distress and much extra expense to immigrants. David Gardner relates that when his father's family came from New York to Wisconsin in 1842 they at first stayed for some weeks with friends at Sun Prairie. Deciding finally to settle in Aztalan, his father sent a teamster to Milwaukee for the furniture but he returned at the end of a week empty, no furniture being found. Gardner then went with the teamster. They searched all through Dousman's warehouse, but to no avail.

- Morrison McMillan, Wis. Hist. Colls., iv, 387.

'D. J. Powers, in Wis. State Agric. Soc., Trans., 1853, 154. "We rejoice at the present signs of their success; they left the green hills of New England and New York for a wilderness which, after years of toil, they have eleared into productive fields; and the rude structures, for habitation and shelter, erected in days of poverty and want, are now with each revolving year, giving place to tasteful and comfortable dwellings. Yet a few years, and orchards of fruit, waving meadows, ornamental groves, and highly cultivated fields will render it difficult for a stranger to surmise, from the appearance of the country, the date of its first settlement." 
Finally Dousman wrote to the warehouse man in Chicago and learned that the goods had been unloaded at that place. Mr. Gardner thereupon sent a team to Chicago to bring them to Aztalan-a very expensive operation. However, when his family arrived there from Sun Prairie, at the end of a long, winter day's sleigh drive, they found everything arranged in the little log house which was to be their first Wisconsin home, and through the kindness of the neighbors a warm fire was glowing on the hearth. The good mother, seeing her household things all about her again after so many vicissitudes, broke down and cried from sheer thankfulness.

When the goods were thus brought from the East, the new homes were furnished much in the style of those the families had just left, save that the equipment was less abundant. But large numbers of immigrants came almost empty-handed and had to depend for most of the household equipment on their own ingenuity. In such cases the crude "outfit" of the claim shanty, already described, had to serve until financial conditions made possible something better. Stoves-or rather, ovens-were something of a luxury. The outdoor oven of stone or brick was fairly common. At the raising of a certain mill, it was said, the good wife cooked at an outdoor oven a wonderful dinner for the men from four townships who assembled to help in erecting the frame. One woman, who boarded fifteen hands working on the first Wisconsin railway, had an inside oven, but it was so small that she was able to bake in it only one pie at a time. However, these were handicaps which were cured by time and prosperity. On the whole, except in distinctly "backwoods" neighborhoods, retarded in development by being cut off from markets, it does not appear that Wisconsin pioneers suffered seriously for the want of ordinary home conveniences.

The same may be said with respect to food. It has become customary, in extolling the virtues of pioneers, to emphasize the extreme hardships they endured in their new homes; and the stories which are told of the occasional settler who found 
it necessary to travel many miles in severe weather to procure food have been generalized to color all narratives, as if this were the usual case. There are instances of real heroism exhibited by men whose duty it was to provide for others in times of scarcity. But on the whole the supplying of food rarely constituted an extreme problem. There never was a "starving time" in early Wisconsin. For one thing, game was abundant and to the skilled hunter easily procurable. If deer became scarce in any neighborhood, due to the absence of favorable coverts, prairie chickens were plentiful in such situations. Of wood pigeons there were literally millions, and water fowl were innumerable. Distances between our new settlements and the older settlements in Illinois and Indiana were not so great as to make it impossible to procure flour and pork by wagon or by sledge overland in winter, when ice on the lake cut off boat communication with the East. People in those older communities, too, were always keenly interested in the marketing possibilities of the new northern settlements and brought in, aside from herds of stock cattle, droves of hogs, and flocks of sheep, many a load of "Hoosier" or "Sucker" pork and flour. Hog and cattle driving was a regular business. Some of the animals were "ornary," to be sure. The hogs have been described as "prairie racers" so lean on their arrival that, if slaughtered at once, fat to fry their meat with had to be added. But it was possible to get them in condition and they were also used for breeding. The cattle were better and served for work oxen, milch cows, and stock cattle. Probably a majority of the herds of southeastern Wisconsin in 1850 could be traced to such importations.

Settlers were always anxious quickly to become independent of the outside world in the matter of regular food supplies. As soon, therefore, as a crop had been produced, the flour and corn mill became a prime necessity. So well was this understood, that no neighborhood was considered established until it could boast a gristmill. It was the first institution, save the school, in' which all settlers had an interest, and unlike the 
school the mill called for a relatively large investment and usually also for the control of the one tract of land containing a water power. Under these circumstances, it is not strange that the building of a mill, although it was financed by private individuals, should have been looked upon as more or less a public enterprise. The early history of Whitewater illustrates these points in a striking manner. In that town it was supposed there was only a single mill site, on section 4 . The land containing it was claimed by one of the first comers, who soon sold his claim right to another immigrant. Meantime, many settlers raised some wheat and corn, so that the need of a mill became acute. They saw that the holder of the claim made no move to erect one, and it was suspected that he could not finance the project. So the settlers held a meeting-their first public meeting, by the way. They resolved: (1) that a mill was an absolute necessity; (2) that the site on section 4 was the only location for it; (3) that the holder of the claim containing the mill site must by a given date either give bonds to build a mill or agree to sell to someone who would give bonds to build a mill. If he refused to do either of these things, he should be run off the claim! The meeting appointed a committee to carry out their policy. The claimant could not build, and after considerable haggling he agreed to place his relinquishment in the hands of the committee, on the payment to him of the sum of $\$ 500$. The committee thereupon sought for a capitalist who would buy the land and build a mill. They found him in the person of Dr. James Tripp; they bid in the land for Mr. Tripp at the Milwaukee land sale in February, 1839 , and put him in possession. He began work at once, and by the middle of June was ready to raise the mill, when the whole countryside came together to help. ${ }^{8}$

The attitude just described is reflected in the legal code. So vital was the social need of gristmills, that the law of Wisconsin Territory, in defiance of the common law on that subject, favored the owner of a mill as against an individual

- A great dinner out of doors, followed by ball games on the prairie, elosed the eventful day. 


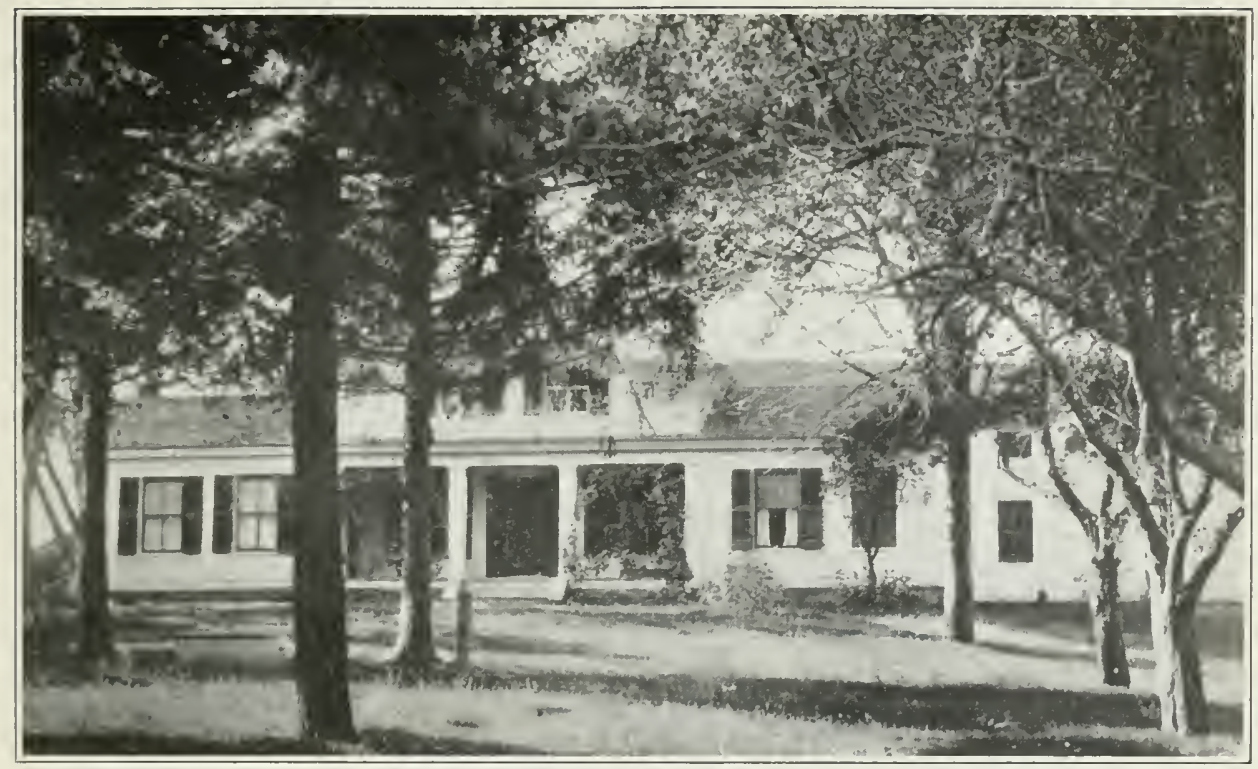

FARA HOME OF JOHX MF. CLARK, NEAR WIITEWATER, BUILT IN $18 \pm 7$

Afterwarks Charles M. Clark's Home

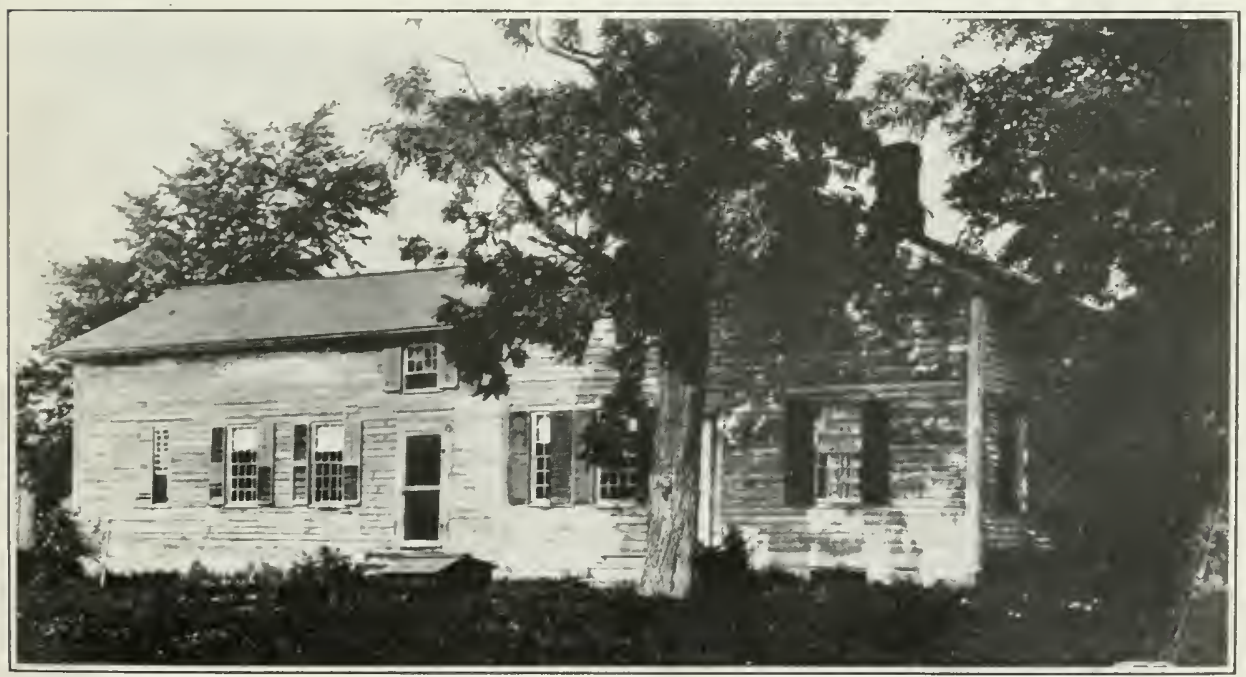

PREVIOL'S HOME OF JOHN IT. CLARK, PAULET, VERMONT 


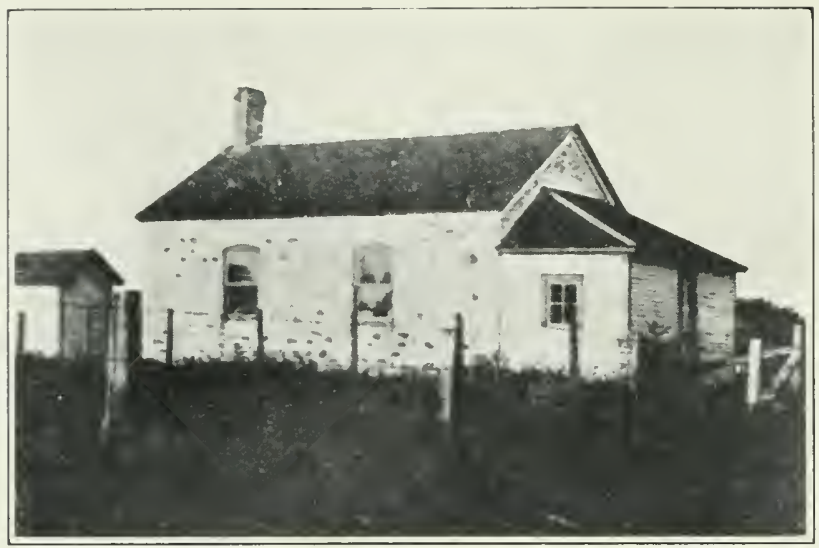

A TYPICAI STONE SCHOOLHOUSE

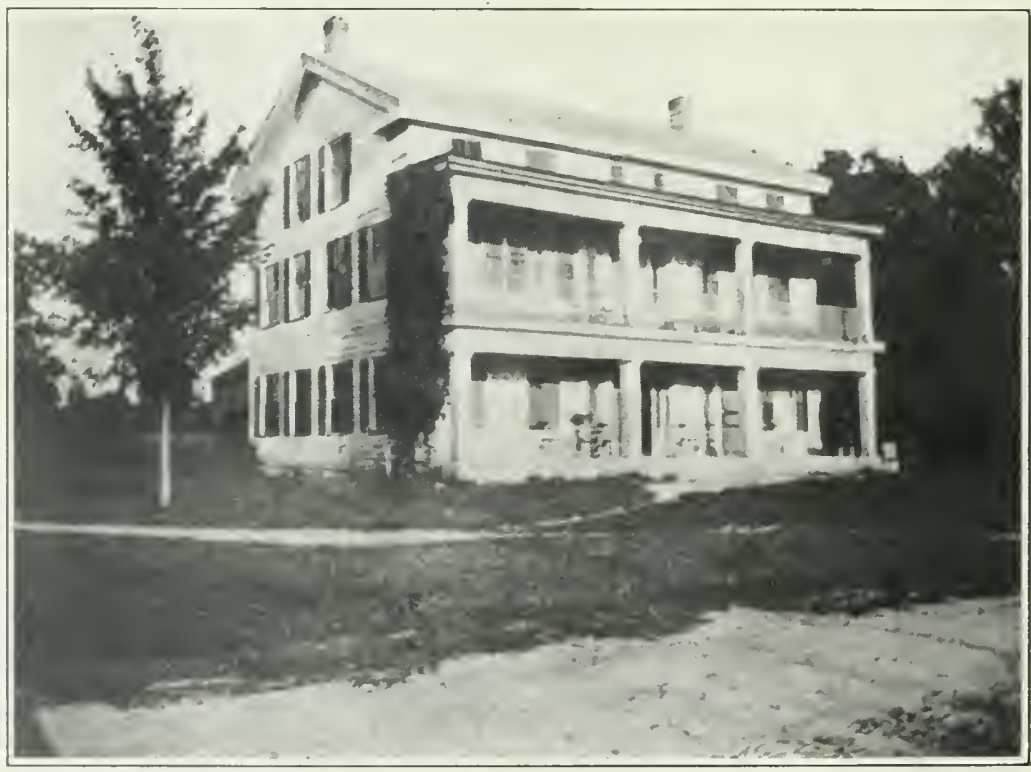

WADE'S HALFWAY HOUSE, GREENBUSH, SHEBOYGAN COUNTY Built 1950 
landowner. If land was flooded as the result of putting in a dam for mill purposes, the owner could not compel the removal or the lowering of the dam in order to save his land. He could at best appeal to a jury for relief and take damages if the jury decided the dam was not too high for milling purposes. This law was upheld by the Wisconsin supreme court. ${ }^{9}$

A good share of the "claim wars" of early days raged round the various mill sites. ${ }^{10}$ The lands which contained these water privileges were so valuable that contests were almost sure to arise. These contests cost money in all cases, and broken heads in not a few. Happy was that miller whose bid had been accepted at the land office and whose mill was built and running.

One of the severest trials endured by the pioneers of Wisconsin was the lack of overland transportation. For not only were there no roads save the Indian trails to begin with, but the nature of the ground was such that in most places dirt roads were sure to be terribly heavy except in the driest part of the summer and in winter. The glaciated area of southeastern Wisconsin is, from one aspect, a series of ridges running north and south, with depressions between, which were apt to contain marshes, streams bordered by wet bottom land, or lakes with marshy fringes. All trails which ran toward the interior from Lake Michigan crossed such depressions every few miles. In very wet weather it required a long string of ox teams, from four to eight, to draw a respectable load over the roads opened along such trails. On the higher ground, especially through the woods, the case was little better, for the soft earth would quickly cut down to the axles of the wagons. Under such circumstances corduroy was the sole relief, and this was a cure which, to the drivers at least, was almost worse than the disease. Early road building, however, consisted in opening trails or widening Indian trails

- John B. Winslow, The Story of a Great Court (Madison, Wis., 1912), 28. Case of Newcomb v. Smith, 2 Pinney, 131.

${ }^{10}$ Such a war, for example, took place over the Geneva mill site. See James Simmons, Annals of Lake Geneva, Wisconsin, 1895-1897 (Lake Geneva, Wis., 1897). 
through the woods, then laying down corduroy across swamps and marshes, and either finding fordable places in the streams or throwing corduroy bridges across them. At the larger streams ferries were maintained.11

By good fortune, military policy required the United States government to build very early the so-called Military Road, which opened a line of communication from Fort Howard (Green Bay) to Fort Winnebago (Portage), and thence by the Military Ridge to Fort Crawford (Prairie du Chien). To this system the government added a road running near Lake Michigan from Chicago to Green Bay. So, at the beginning of rapid settlement by farmers southern Wisconsin had a main road, such as it was, all around the border of its territory except the south, and this was mostly prairie with comparatively easy trails across it into Wisconsin Territory. The people of the lead region, as pointed out in chapter two, had trails leading to the Mississippi, to Chicago, to the Wisconsin, and to Fort Winnebago. Their main highway ran north from Galena to Mineral Point. This was soon connected with the Military Road. It was not uncommon in the early years for persons wishing to reach Mineral Point from the lake ports to travel the long, circuitous route by Green Bay, Fort Winnebago, and Blue Mounds, instead of attempting the hazardous direct trip overland.

The settling up of the southeastern counties compelled the building of roads inland from the ports, and on this enterprise Milwaukee exerted a powerful influence. The result was a fairly complete system of roads from Milwaukee to the great settled areas of the state, as shown on the map (Fig. 15). The Janesville road, the Madison road (built promptly after the

\footnotetext{
${ }^{11}$ At Beloit, as early as 1837, a current boat served for a ferry across Rock River. This was a type of ferry much used in early Wisconsin. The current boat was a flatboat which worked by two ropes ending in pulleys (one rope attached at each end of the boat) on a cable or hawser stretched across the stream and attached strongly to a tree on either bank. The boat's ropes could be lengthened or shortened at will, and when the one was lengthened the pressure of the eurrent drove it across in one direction; when the other was lengthened it moved across in the opposite direction. Such ferryboats were found on eastern streams just after the Revolution. They are still found today in the far West.
} 


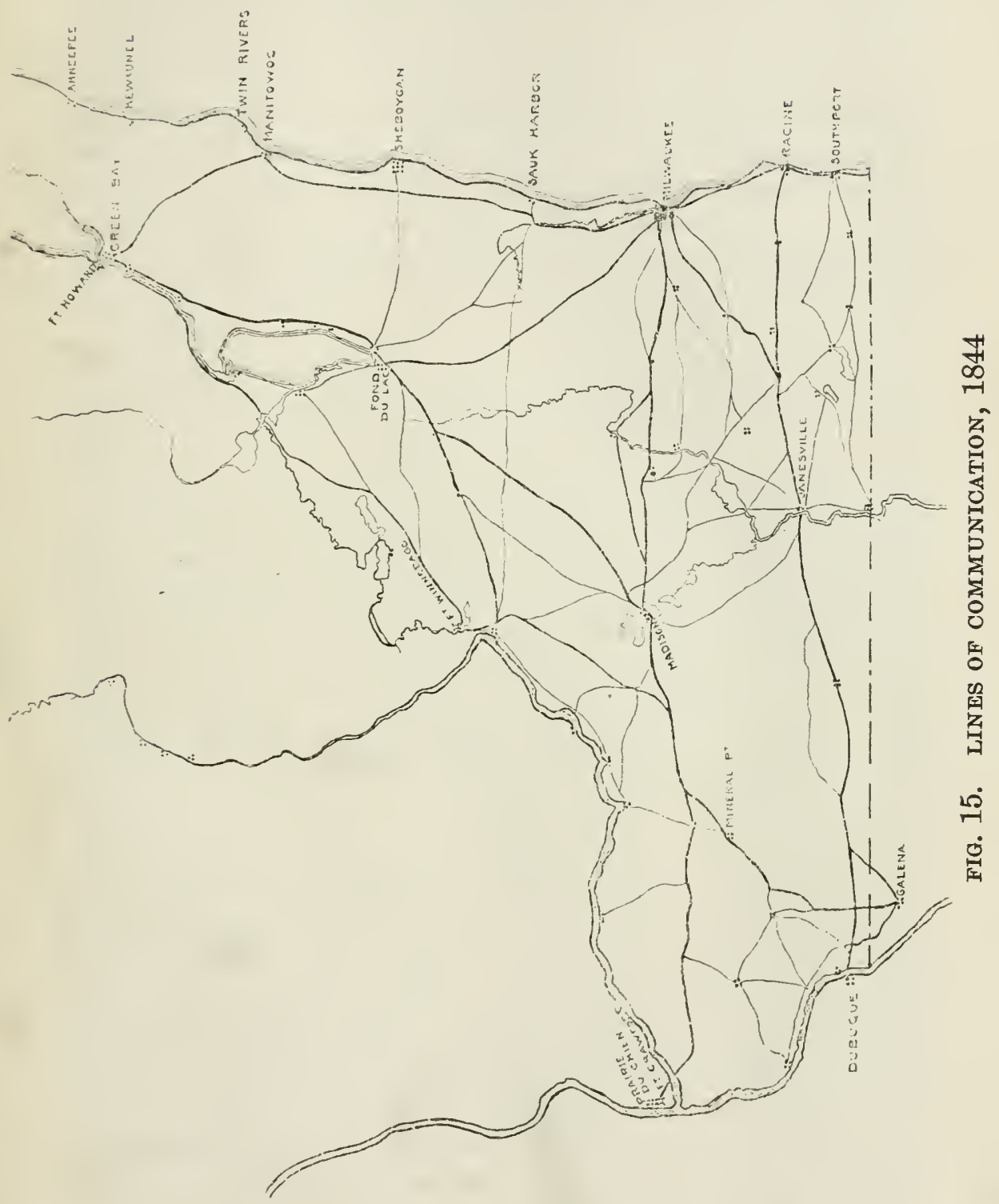


location of the capital at that place), the Mineral Point road are famous in the annals of early Milwaukee trade, and as settlement spread north into Washington, Dodge, and Fond du Lac counties, other highways radiated from the commercial center on the lake to those regions, and each trunk road had many local feeders. Before 1850 the work of planking some of these roads was begun, the first determined effort to secure "good roads." Other roads were built from Racine and Kenosha into Walworth, Rock, and Green counties. At least one of these, the road from Racine to Burlington, was planked as early as $1846 .^{12}$

Farmers found the plank roads a comfort, but disliked to pay the tolls charged for their use. Though the dirt roads were public and free, they were compelled to pay enormous tolls in time and in draft stock when they hauled their crops to market. The climate, however, was in this respect merciful. When the ground was frozen solid and covered deeply with snow and ice, a condition was created which usually rendered transportation cheap and easy during a number of weeks in winter. Then was the time for getting saw-logs to the mill, splitting and hauling rails for fencing, bringing home the year's supply of wood, assembling building material and, in a word, doing all the heavy draying which by any means could be deferred to the winter season.

The winter also was the approved time for clearing land. The cold days were favorable for chopping. So the timber was felled, the best logs taken to mill, and other heavy logs sawed into proper lengths for rolling into log heaps. Small stuff was piled into brush heaps. When warm, dry days came in spring, great log and brush fires quickly cleared the land, leaving a depth of ashes which might be hauled off to be converted into potash and pearlash for the market. The larger stumps, of course, remained either until they rotted out or until the settler was able to "stump" his land by artificial

${ }^{12}$ Papers of Edwin Bottomley, Wis. Hist. Colls., Xxv. 
means. ${ }^{13}$ The smaller stumps and "grubs" were removed either before breaking the land or during the breaking process.

The rapidity of the clearing operation depended on the density of the timber growth. In heavy timber a farmer would do remarkably well to chop from three to five acres in a winter and clear it in spring. In openings the area might be three or four times as much. Some thinly timbered valley land in southwestern Wisconsin was cleared about as fast as a breaking team could break up the land. On the prairies a large farm could be opened in a single season. Frederick Starin measured the season's breaking of one Whitewater settler and found it amounted to " 81 acres, 2 rods, and 111/2 poles."

Suppose that some Timothy Dwight of a later time, instead of Travels in New England, had written Travels in Wisconsin, what rural pictures would he have seen? Starting northward by the Chicago-Green Bay road, through the towns of Kenosha and Racine counties, he would have found the prairies and openings well settled with farmsteads about every half-mile on the average. The houses and other buildings were nearly all frame structures. The pioneer log houses which remained were used as stables or storerooms, or occasionally for giving temporary shelter to some immigrant family. Near the homes were gardens, fruit trees, and groves. The cultivated fields were ample, and all were enclosed, usually with rail fences though in some cases neat board fences had been run around the nearer fields as well as around house and garden. Sod fences were used in some new prairie districts. The scene was not unlike that which Dwight witnessed in the Connecticut valley in Massachusetts, save that the farms were generally larger and the houses were not clustered in villages. All unenclosed lands-and these were still plentiful-made up of

\footnotetext{
${ }^{13}$ One way was to use ox power to draw the stumps out, a moderate amount of digging and chopping of holding roots being done by hand. Another was to employ laborers to grub them out. Hardwood stumps rotted so rapidly that a few years saw a field cleared by the natural process.
} 
swamps, dry prairies, woodlands, the highways, and school sections, were "commons" for the livestock of the settlers.

On striking the heavy timber in Milwaukee County the aspect of things changed for our traveler. The farms for a time were quite as numerous as before, but hewed log houses took the place of frame, the fields were much smaller, the commons-mostly woods and swales-more extensive. Everything betokened a more primitive stage of farming, due not to difference in years of settlement but to the external obstacle of heavily timbered lands and to the circumstance that these were taken up, or purchased, mainly by an economically weaker class of settlers than those who occupied the southern counties.

Swinging westward after traversing the big bend to Green Bay and south to Lake Winnebago, the traveler found himself in the fertile prairies and openings of Fond du Lac and Columbia counties. Here once more the prospect brightened. Farms multiplied and prosperity, if not fully achieved, was approaching, as testified not merely by the demeanor of the farmers but by the condition of their homes and their farms. For they were living within possible hauling distance of the lake ports; their lands, easily cleared and bountiful, had produced much grain for the market; and was not the Fox River Canal about to open a cheap transportation line to Green Bay, and the railroad another to Milwaukee and Chicago? Americans from New York and Vermont had settled in that region in considerable numbers, and added to these were Germans of the ' 48 immigration and other foreigners. This region, as well as parts of Dodge, Columbia, and Dane counties, was beginning to emerge from the hewed-log stage of rurality into that of the frame house. But the change had been only partially accomplished. It would not be completed for a few years yet, till the railway line, already lengthening westward from Milwaukee, should reach far enough west and north to serve these extensive areas. 
The railway was also to awaken to full life the vast agricultural possibilities of the old lead region, with the big prairie which lay like a huge blanket over the Military Ridge, and the scenic valleys intercepted by the Wisconsin where as yet the deer had been rarely startled by the ring of the settler's ax. The lead region was still a world of its own, due to its mining history, but with the new immigration it was settling into its true character as an agricultural region. The outlying populations, north of the Wisconsin in Crawford, Richland, and Sauk counties, were still prevailingly in the round log, girdled tree, corduroy stage.

If, however, without penetrating into the wilderness, entering the lead region, or traversing the big prairie by the Military Road, our traveler drove east from Madison on the Milwaukee road, his route lay partly through an extensive settlement of Norwegians living on prairie and opening, who though deficient in capital had been making a gallant fight against odds in establishing and improving their farms so as to take advantage of the new transportation facilities then about to be realized. The log house, in both the round and the hewed, was the symbol of that struggle. Farther east, in Jefferson and Waukesha counties, he found the social landscape variegated. One hour his course would lie through a settlement which, judged from its architecture rather than from its farming improvements, was primitive to the verge of crudeness. The next hour his eye rested upon the tidy frame cottages, with groves, gardens, and neatly enclosed fields betokening the most advanced cultivation to be found in the new state. The latter signalized older settlement, more adequate capital, and a less obdurate problem of clearing, quite as much as an ideal of rural life brought from the East. The foreign immigrant usually found himself restricted in choice of land to what American pioneers had shunned, especially the heavily timbered tracts.

By driving south from Milwaukee to Racine, then west on the plank road to Rochester, thence to Whitewater, Janesville, 
and down the Rock River valley, our traveler might have seen the very heart of Wisconsin's farming area as it was in 1850 . Here was a region which socially promised to be a second western New York, whose cultivation already suggested that of the New England of sixty years earlier. With a long and heavy haul to market, farming had yet gone forward rapidly, and already millions of wheat was finding its way from these generous fields to the warehouses and docks along Lake Michigan.

Our supposititious observer, as a valiant traveler, requiring rest and refreshment from time to time, would be sure to take special note of the taverns which stood at intervals of a few miles along all the main highways. Also, as a man of social intelligence, he would be interested in the country schoolhouses, which were even more numerous and more widely distributed. The first would be, in almost all cases, good frame structures; the last, save in the more advanced neighborhoods, would be inferior buildings either of round or of hewed logs. ${ }^{14}$ Our traveler would be sure to encounter, on all main roads, the "stages" that carried the mail to all the farming communities, in addition to conveying passengers from place to place. ${ }^{15}$

${ }^{11} \mathrm{~J}$. H. A. Lacher, in Wis. Hist. Soc., Proc., 1914, gives an interesting account of early taverns and stages. In Pickard's report as state school superintendent, for 1860 , we find that at that time Wisconsin had $1405 \mathrm{log}$ schoolhouses, doubtless all in the rural districts. There were 2297 frame houses, 177 brick, and 166 stone.

${ }^{15}$ For a good brief summary of the stage routes in 1848 , see Louise Phelps Kellogg, "The Story of Wiseonsin," in Wis. Mag. of Hist., iii, $199 \mathrm{ff}$. 


\section{CHAPTER V}

\section{WHEAT FARMING}

"In the rapidity of the rise and decline of the wheat industry, and in the extent of that decline, Wisconsin is unique among the states of the United States that have been important in wheat culture." 1 This statement epitomizes the story we have to tell, more in detail, in the present chapter.

When the new prairie settler of Wisconsin, in 1836, cracked his ox-whip and struck the breaking plow into the sod, preparatory to raising a crop of wheat, there was not being produced in the United States an amount of that great food cereal much in excess of the reasonable requirements of our own people. The population of the country in 1840 was, in round numbers, $17,000,000$. The total production of wheat the preceding year was $85,000,000$ bushels, or an average of 5 bushels per capita. That is only a half-bushel per capita more than the average, for food and seed wheat, of the entire wheat eating population of the world in recent years, while it is considerably below the present average of consumption in both America and Great Britain. ${ }^{2}$ With an abundance of corn, which was the staple food of the slaves and made an important item also in that of a good proportion of the white population, a part of this wheat could be spared for export. However, practically the problem of the foreign market for wheat had not yet arisen in an acute form.

Moreover, that problem was not destined to arise until after the new territory of Wisconsin had entered definitely and fully upon its career as a wheat producing area, for in the ten years following 1840 the increase in the home market outran the increase in the wheat supply. That is to say, the popula-

${ }^{1}$ John Giffin Thompson, The Rise and Decline of the Wheat Growing Industry in Wisconsin. University of Wisconsin Bulletins, Economics and Political Science Series, vol. $\nabla$, no. 3, p. $13,295-544$.

'Sir William Crookes, The Wheat Problem (New York, 1900), 9, 13. 
tion in 1850 was $23,000,000$, an increase of $6,000,000$, or 35 per cent, while the wheat production of 1849 was only $100,000,000$, or an increase over 1839 of 17.6 per cent.

We were, however, prepared to spare a goodly bulk of the annual crop for export as early as $1849 ;^{3}$ and ten years later, the crop having grown 73 per cent and the population only 30 per cent, the foreign market had become a matter of crucial concern to American farmers. With the spread of wheat growing over the vast fertile stretches of the great plains during the years following the Civil War, America entered upon the production of an enormous annual surplus of wheat which has influenced the economic history of the world. ${ }^{4}$

The principal foreign market for American wheat, from the beginning of our period, was Great Britain. ${ }^{5}$ Fortunately for us, the demand in that country began to exceed the home supply almost at the exact moment when the supply with us began greatly to exceed the home demand. Population in Great Britain, after the close of the Napoleonic wars, under the stimulus of manufacturing and commerce went forward with mighty strides. The additions, however, were mainly in the towns and in the manufacturing counties, while the rural population grew but slowly or not at all. By the census of 1831 almost exactly two-thirds of the British population were living in towns, and the proportion thereafter tended to become more unfavorable to agriculture. In consequence the British farmers, who had customarily supplied the home demand for wheat, or nearly so, fell behind the requirements of the nation even with the stimulus of the "corn laws," which prohibited importations except in times of scarcity. Then ensued the notable and tremendous campaign against the corn laws and finally, in 1846, their repeal. The industrial classes, demanding cheap food, had triumphed over the agricultural classes

'The production of 1849 was considerably lower than that of 1848 and 1847 .

"See William Trimble, "Historical Aspects of the Surplus Food Production," American Historical Association, Annual Report, 1918, 223-239.

- Colonial America had shipped to Great Britain as well as to the British, French, and Spanish West Indies. 
demanding an assured market and a high price for wheat ("corn").

In addition to the disproportionate growth of the non-rural population, two other causes in Great Britain affected the home supply of wheat, in proportion to demand. These were the withdrawal of land from agriculture and an important, though gradual, change in the character of British agriculture. In the twenty years between 1851 and 1871 the total area of farm land taken into town limits and absorbed by railroads for rights of way, etc. amounted to nearly 700,000 acres. This was considerably in excess of the extent of new enclosures authorized during the same period, while the average value of the withdrawn lands, for cropping purposes, was naturally much higher than of that newly enclosed. ${ }^{6}$ During the period under discussion improvements in farming were numerous. Yet the agricultural classes were called upon to endure several sharp and general crises, and whenever a severe depression came it was observed that the grain growing districts suffered more than those sections where livestock was the dominant interest. $^{i}$ Such practical demonstrations gave point to the exhortations for better farming, with more thorough cultivation, fertilization of the soil, proper rotation of crops, feeding of livestock, and the like. The result was a more or less unifor'm tendency away from the emphasis on wheat growing, which had become something of an obsession under the artificial stimulation of the corn laws. More and more attention was centered upon the production of meat and wool. This tendency ultimately became so powerful that, between 1871 and 1891, the area devoted to wheat culture declined from $3,572,000$ acres ta $1,889,000$ acres, or 47.1 per cent, while the acreage of hay increased 20.2 per cent and of pasture 30.7 per cent. 8 Great Britain, therefore, as a predominantly industrial nation, which for industrial reasons adopted the free trade

- Great Britain, Parliamentary Papers, Reports of Commissions, House of Commons, 1875 , ii, 3.

'W. H. R. Curtler, A Short History of English Agriculture (Oxford, Eng., 1909), 285.

- Sir William Crookes, op. cit., 122. 
policy, was the natural market for America's surplus wheat, and became, during the years when that surplus grew to immense proportions, the arbiter of prices to the American wheat farmer.

At the time Wisconsin began to raise wheat as a business, the outstanding producers among the older states were Pennsylvania, New York, Virginia, and Ohio. Of the 85,000,000 bushels in the crop of 1840 (or 1839) ${ }^{9}$ these four states are credited with over 53,000,000. Maryland, Tennessee, Kentucky, Indiana, and Illinois yielded 22,000,000 more, while the remaining 12,000,000 was distributed, in small amounts, among the other twenty-one states. The older states made shift to hold their own for some years, but there was little expansion save during the food crisis years of the Civil War, and meantime the non-agricultural populations of these same states were increasing so rapidly as to provide in large part a home market for the wheat raised within their own borders. This left to the new western states the opportunity of providing a supply for the foreign trade, and the eagerness with which that opportunity was improved the story of Wisconsin wheat growing during half a century will show.

The New York farmers, the Pennsylvania farmers, the Ohio farmers who came to Wisconsin in the early rush of settlement were by habit and tradition primarily wheat growers. The New Englanders had been partially weaned from the business, but, like the others, they had a lively appreciation of the ease with which wealth in the form of wheat could be extracted from the limestone soils of Wisconsin's prairies and openings. The problem was to get the soil under cultivation with the least practicable delay, and this, on the prairies at least, was accomplished with remarkable celerity. To illustrate, the farm lands of Mount Pleasant Town, Racine County, began to be claimed in $1836 .{ }^{10}$ In the season of 1837 some claimholders (who had not yet bought their lands) harvested 1000

- It is not quite clear whether the figures are for the one year or for the other.

${ }^{10}$ Except a few pieces which were claimed the previous year. 
to 2000 bushels of wheat. ${ }^{11}$ In the summer of 1844 two young men, with ten yoke of oxen, and a couple of boys to drive, broke up in a few weeks 200 acres of Rock County prairie which they sowed to wheat. The next year they harvested their crop with a machine and secured 5000 bushels, a part of which was sold at Racine at sixty-two and one-half cents per bushel. ${ }^{12}$ These figures could be matched from other quarter's, and they suggest that it was probably not uncommon for a farmer to break up and sow to wheat 25 to 50 acres during his first season's operations. After that his fields expanded rapidly. The custom was to sow wheat year after year on the same ground, so that, in general, the increments of "new breaking"' simply augmented the area sown to wheat, other crops like oats and potatoes occupying very minor portions of the arable, and hay being derived from the natural meadows or marshes. In case the land was openings instead of prairie-and many at first preferred this type, believing it to be better, especially for winter wheat-the timber was quickly cliopped off to make rails for fencing. The ground, being soft and protected by a layer of humus, was easier to break than the prairie sod. The tree stumps interfered with the plow, but these either were left to rot away or were gradually grubbed out. Smaller trees, of which the openings had but few, and brush like the ubiquitous hazel were cleared away before starting the plow.

Thus in a brief span, almost as if by some sort of magic, were the prairies and openings of southern Wisconsin transformed into fields of billowing wheat. The study of towns from the charts and plats reveals the dynamics of the process. $^{13}$ As early as the census of 1850 , the improved lands in the farms of Mount Pleasant amounted on the average to four times the acreage of the unimproved. That was an exceptional case, for it appears that no other town at that census period showed as high a proportion of improved land. Yet,

${ }^{11}$ Racine Argus, Mar. 10, 1838.

${ }^{12}$ U. S. 29th Cong. 1st Sess. Sen. Doc. 307, p. 138.

2 See agricultural charts of twenty-five towns, also Atlas, Farms and Farmers of 1860, in Domesday Book, Town Studies, I (in press). 
four of the eight towns in Racine County had half or more than half of their farm lands improved, the four together showing 30,205 acres improved to 28,541 unimproved. The other towns, lying farther from the lake shore, were less developed. For the county as a whole the figures are 63,338 improved and 82,947 unimproved. For Kenosha, the other lake-shore prairie county, the totals are 50,987 and 79,862 respectively.

Surprising as it may seem, Rock County, whose farmers had a haul of 60 to 100 miles to the lake ports, already had in its made farms more improved land than unimproved. The figures are 143,235 and 137,111 respectively. The explanation is found in the extensive and beautiful prairie area bordered by and interspersed with timber, combined with easily cleared openings, which made that county so enticing to the early settlers; and also, in its relatively small amounts of marsh land.14 Seven other counties-Dane, Grant, Green, Lafayette, Milwaukee, Walworth, and Waukesha-each showed improvements in 1850 which exceeded a third of all lands included in their farms. All of these except Milwaukee had much prairie and openings. ${ }^{15}$ Some of the counties, especially Grant, Dane, and Green, had within their boundaries considerable areas of rough hill land, but these were not yet largely occupied for farming purposes; so that in all cases, practically, we are dealing with farms which are in process of making on the prairies or in the smooth or rolling openings. These totals indicate how rapidly such lands were being brought into requisition for the growing of wheat, and the totals of the eighth census (1860) produce a still more striking impression. By that time the ten counties listed above had

16 If the marshes which were mowed or pastured had been described as improved land, as tame grass meadows and pastures were, the unimproved in all of the southeastern counties would have shrunk appreciably.

${ }^{16}$ Milwaukee's unusual commercial advantages account for the rapid improvement of her forested lands, which is an exceptional ease. Comparison with Illinois is interesting. In 1850 the 57 Illinois counties show 11 which have a balance in favor of improved land; 47 others have less than one-half their farm lands improved; 7 have one-third. In 1860,41 of the 62 counties in Illinois had a majority of their farm lands improved. 
a combined improved area totaling 1,693,491 as against an unimproved of $1,338,750$. If we eliminate the counties of Dane, Grant, and Green, where many new farms were making on rough land much of which would never be cultivated, the totals for the other seven counties would be $1,060,587$ and 675,590 . That is, the improved land in those counties was to the unimproved in the proportion of 10 to 6.7. This is a higher average of improved land than either Ohio or Pennsylvania, as a whole, had in 1850 in their farms.

One wonders how a farmer in 1837 harvested a crop of wheat yielding 2000 bushels. This represented at the very least 50 acres and probably more. The harvesting implements were as yet the old cradle for cutting and the wooden rake for forming the sheaves. A strong man could cradle two to three acres per day, and a few celebrated cradlers of the pioneer time had records of four acres or even more. Perhaps two and one-half acres would be a rather high average. At that rate a ficld of 50 acres would supply full work for one man for twenty days. Four men, however, could cut the crop in five days, and that period-or say a week-the farmer might ordinarily count on before the grain became too ripe to handle without waste. Allowing two binders to each cradler, the requisite harvest help would number at least twelve men. During the early years newly arrived American immigrants, who were looking for claims, were utilized for harvest labor, while later the immigrations from Europe supplemented the native supply. But often a scarcity of labor was experienced in given communities. The harvest was the harvest; on it depended the prosperity not alone of the farmer but of the merchant, the doctor, and everybody who had a stake in the community. So it is not surprising that every able-bodied person, male and female. was at times requisitioned to help save the wheat crop.

Wisconsin was settled precisely at the time when new inventions in harvesting machinery began to make their appearance after ages of dependence on implements little more com- 
plex than the sickle with which Ruth gleaned in the fields of Boaz. Cyrus McCormick patented his reaper in 1834. The McCormick Reaper Company began to manufacture machines at Chicago in $1846,{ }^{16}$ and by 1850 this and other reapers were generally used in the prairie fields of Wisconsin. George Esterly of Heart Prairie, Walworth County, invented a reaper which became very popular. The Civil War, which absorbed so large a proportion of the labor force, ${ }^{1-}$ made the use of reapers compulsory even on comparatively small farms. ${ }^{18}$

It is not usual to associate the idea of bonanza farming with Wisconsin. Yet we are given, in the newspapers, a harvesting scene of the year 1860 which suggests the Red River valley wheat industry of ten, twenty, and thirty years later. The DeForest farm in Dane County contained 2200 acres, of which 1000 was in grain. The wheat acreage was 800 , bearing a crop in that golden year estimated at 25,000 bushels. In harvesting his wheat Mr. DeForest employed eight reaping machines and sixty men. ${ }^{19}$ The reapers were doubtless of the handraking variety, requiring two men to operate them. Five binders could keep up with a machine, and if four men were kept steadily at work "shocking up," the sixty hands are accounted for. The self-raking reaper, the Marsh harvester,

\footnotetext{
${ }^{16}$ Reuben G. Thwaites, "Cyrus Hall MeCormick," in Wis. Hist. Soc., Proc., 1908, 242ff; also, letter of Herbert A. Kellar, McCormick Library, Chicago, dated May 6, 1922.

${ }^{17}$ ' Up to December 31, 1864, Wisconsin furnished 75,000 men for the federal service, and by the end of the war this number had increased to 91,379 men, or one man for every nirue of the inhabitants of the state." Thompson, Wheat Growing, 61-62. See Frederick Merk, Economic History of Wisconsin during the Civil War Decade (Madison, Wis., 1916), especially p. 52-56.

${ }^{18}$ The McCormick Company maintained agencies in all connties. Their agents reported the conditions affecting sales and collections, number of machines sold, facts about competition, etc. These are still in manuscript in the McCormick Agricultural Library, Chicago. A summary of sales of machines, taken from those sources, has been supplied by Herbert A. Kellar, librarian of the McCormick Library. This shows that the McCormick Company delivered to Wisconsin agents 164 reapers in 1849, 96 in 1850, 60 in 1855, 292 in 1860, and 302 in 1861. Numerous other machines competed with the McCormick, among them the Esterly reaper, the Beloit reaper, the Manny reaper, and the Kirby reaper. Of the last named, about 200 were sold for the harvest of 1860 (see Wisconsin Farmer, xii, 389). In 1861 the Agricultural Society declared that at least 3000 reapers of different makes had been sold in Wisconsin for the harvest of 1860 (Wis. Farmer, xiii, 94).

${ }^{19}$ Milwaukee Sentinel. Quoted in Manitowoc County Herald, Ang. 23, 1860.
} 


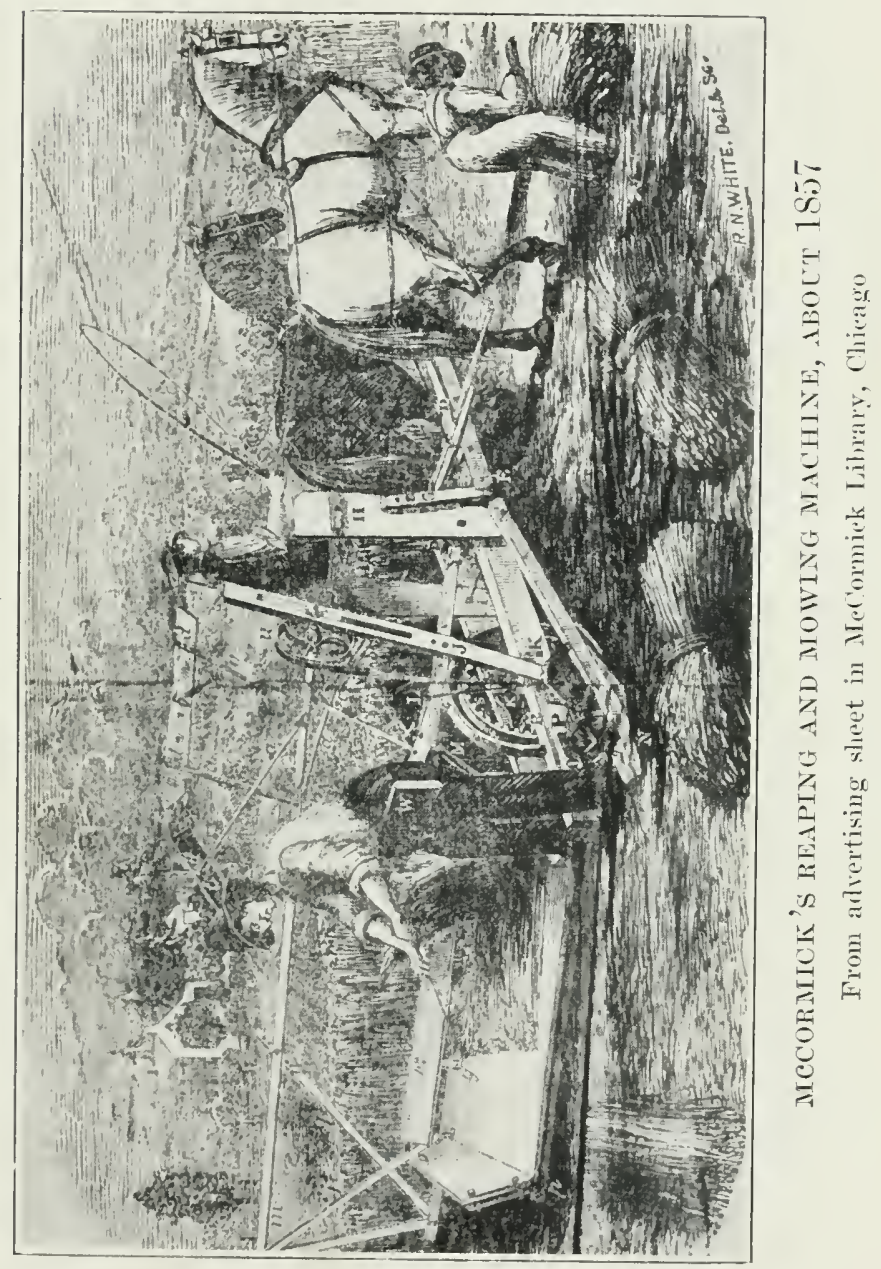




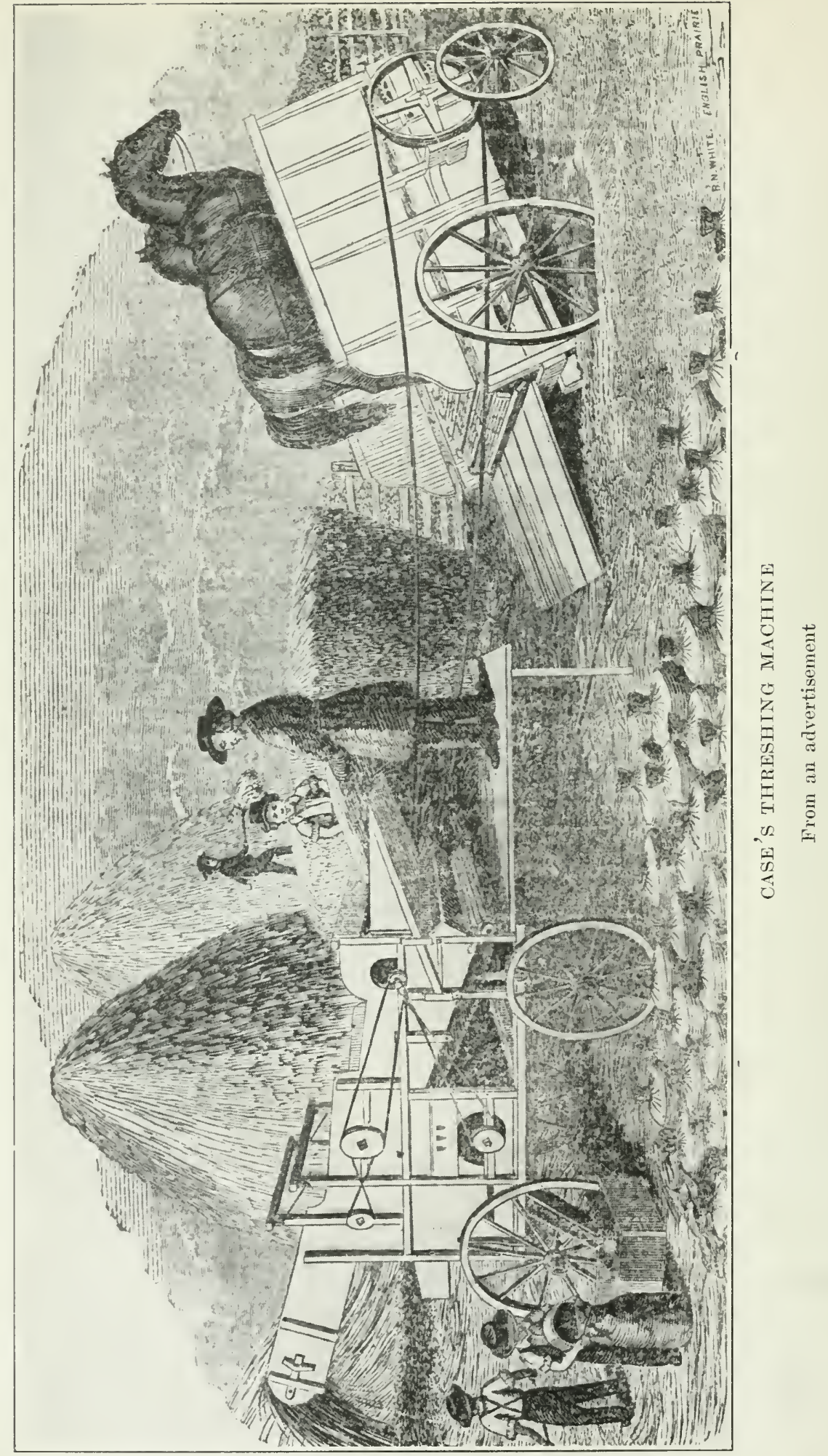


and especially the self-binder, ${ }^{20}$ invented by a Wisconsin man, John F'. Appleby, progressively reduced the amount of labor incident to harvesting grain.

Threshing with the flail was not done to any considerable extent in Wisconsin. Some of the early crops were threshed by the old Bible method of driving animals over the grain to tread out the wheat. ${ }^{21}$ Some use was made, also, of a little fanning-mill-like thresher mounted on a wagon-bed, the power being supplied by the moving wagon wheels. ${ }^{22}$ 'This machine distributed the straw over the field and dropped the shelled grain in the wagon box. It was not very successful. However, the invention and manufacture of threshing machinery came soon to be a Wisconsin specialty. A small, two-horse tread power machine was built and sold by J. I. Case in Racine beginning in 1849 . The next year a sweep power machine began to be manufactured also in Racine. Case improved his thresher, bringing out several different models, and finally the Case machine, driven by a ten-horse sweep power, became the standard wheat thresher of the great wheat era, though other machines, like the Buffalo-Pitts and the old "Vibrator," similarly driven, were also widely used. The season of threshing, like the harvest, was a time of heavy labor, but it was relieved by being made also a social event. "Changing works" was practised universally, at least among the smaller farmers; the household boarded the threshing crew and other hands, generally furnishing sumptuous meals with chicken, cakes, pies, and puddings for the gala occasion. ${ }^{23}$

The marketing of the crop, while in some respects the most crucial of the processes connected with wheat growing, could usually be attended to with some deliberation, by the farmer aided by his regular help. It was not, in the same sense as

${ }^{20}$ Such a binder was invented by .Tohn F. Appleby of Wisconsin. His original "knotter" ( see cut) is in the State Historical Museum.

${ }^{21}$ Hence the ancient aphorism, quoted by St. Paul: "Muzzle not the ox when he treadeth out the grain.",

${ }^{2}$ Such a machine was used at Whitewater in the early forties. Interview with Julius C. Birge.

${ }^{2}$ The classic description of a Wisconsin farm threshing scene is found in Hamlin Garland's $A$ Son of the Middle Border (New York, 1917), $50 \mathrm{ff}$. 
harvesting and threshing, an emergency job. Nevertheless, during the early years it was a long, tedious, costly business to market a big crop of wheat. Forty bushels made a load weighing 2400 pounds. With a team of horses this might be hauled, at the rate of twenty to thirty miles per day, over the rough, rutty, dusty or muddy roads. The number of days consumed in marketing a load of wheat depended on the distance from market and the condition of the roads. For the farmers in the more westerly counties it is easy to see that a week or even ten days would be required. Multiply the number of days, whatever it was in a given case, by twenty-five, the number of loads in a crop measuring 1000 bushels, and see what becomes of the wheat farmer's fall and winter. The money expense, if the teamster had always to put up at the taverns which stood invitingly at distances of four or five miles along the main roads, in many cases would have exceeded the gross returns for a load of wheat. The farmers practised economy by taking some portion of the necessary supplies with them and camping out along the route. They also planned, as far as practicable, to secure return loads either for themselves or for others, which again reduced the cost.

It must have required considerable courage to start off from Whitewater, Lima, Koshkonong, or Plymouth with a load of wheat when the price at Milwaukee was known to be 40,50 or 60 cents per bushel. In the first ten years of Wisconsin wheat growing the price never exceeded 90 cents, and frequently it was as low as 44 to 50 cents. Such persistent low prices, combined with a succession of bad crops in 1850 and 1853 (the pink-eye years), proved all but fatal to Wisconsin farming. These conditions are reflected in the emigration to California, which reached large proportions after $1849,{ }^{24}$ in the universal complaint of "hard times," the equally universal mortgage

\footnotetext{
24 Two thousand persons of Wisconsin nativity were found in California in 1860 , and this was only a certain proportion of those who were from Wisconsin, most of whom, no doubt, were born in other states. California had 28,659 New Yorkers, and since there were more New Yorkers than native Badgers in Wisconsin in 1850 , it is reasonable to assume that several thousand of them went to California.
} 
indebtedness among the farmers, the lack of credit, the extortionate interest rates. They are reflected likewise in the success of railroad financiers in persuading the farmers to mortgage their farms in the hope of securing transportation facilities which would reduce freights and virtually add to the price of their products. ${ }^{25}$

A new epoch opened with the harvest of 1853, which was the first reasonably good crop since 1849. By that time the Milwaukee and Mississippi Railroad had built west to Rock River valley, so that the crop could be marketed at much less cost than formerly. The crop of 1854 was even better, while the market price now took such a sharp turn upward as to give the farmer once more the coveted "dollar a bushel" for his wheat. The high prices continued for about five years, railroad building meantime progressing in wholly unprecedented fashion. One line was completed to Prairie du Chien (1857), another to La Crosse (1858), and still another to Fond du Lac (1859). The air was full of other projects. During this same period southern Wisconsin experienced its most pronounced expansion of the wheat area. Many of the larger prairies, which men preferring the openings ventured into with some reluctance, were broken up during these years. The thinly wooded valleys of the Driftless Area were cleared and turned to account with surprising rapidity. The sale of the school lands on especially easy terms stimulated the purchase both by settlers and by speculators of those lands. ${ }^{26}$ Many of them -especially those belonging to the " 500,000 acres"-lay outside of the limits of southern Wisconsin, and their sale stimulated the settlement of more northerly wheat lands. The enormous leap upward in production from 4,286,000 bushels in 1849 (which was more than twice the highest product for any previous year) to $9,000,000$ in 1855 and $12,000,000$ and $14,000,000$ respectively for the next two years tells a story of

${ }^{25}$ Among the positive effects of the bad years was the agitation for better, more scientific farming.

"See the author's paper, "Wisconsin's Farm Loan Law," in Wis. Hist. Soc., Proc., 1920. 
expansion which is fully borne out by the statistics of population increase in the wheat growing counties.

There followed, in 1858 and 1859, two bad years, the latter marked by an unusually severe drought. Everything dried up. Not only was the grain crop negligible, but grass and hay were deficient; potatoes, roots, all were failures. The winter of 1859-60 was, however, mercifully mild, open, and terminated by an unprecedentedly early spring. There had been practically no snow to relieve the drought, and when farmers began sowing wheat in March it was with but faint hope of a harvest. The sown grain, it is said, lay in the dust-dry soil for a month without sprouting. Then came the rains, steady, continuous, abundant, and the crop was made. It was such a crop as Wisconsin had not seen, even in the palmy days of the early pioneers. Many fields yielded 35, 40, even 45 bushels per acre. Hardly any gave meager returns. The average yield per acre for the entire state was 24.5 bushels, and the total amount which Wisconsin poured into the world's trade or held over to feed the armies of the Union in the years following was between twenty-seven and thirty million bushels. The price was not up to the mark of previous years, yet neither was it excessively low, standing around 80 cents at Milwaukee. Farmers, by the thousands, paid off their debts, and the state was enabled thereby the better to meet the shock of the Civil War, in which Wisconsin took so honorable a part.

So much must be placed to the credit of the wheat crop of the "golden year," as 1860 has been called. It seemed almost as if it had been providentially designed with reference to the need, in food and financial power, which the people were called to meet. ${ }^{2 \tau}$ The evil effect of the wonder crop was to reënkindle the gambling spirit in the Wisconsin farmers. They were obliged, of course, to push wheat culture to the limit of their

\footnotetext{
${ }^{27}$ The great crop, however, was explained on very simple scientific principles by Mr. J. W. Hoyt, editor of the Wisconsin Farmer. See vol. xiii, p. 34. He said the drought of the previous year had subsoiled "our abused and surface-exhausted land," making availal,le for the young wheat plants some of the earth salts absolutely necessary to their successful growth, of which continual eropping had robbed the surface soil. These salts had come up into the surface layers under the influence of capillation and had been held by the dry upper layer.
} 


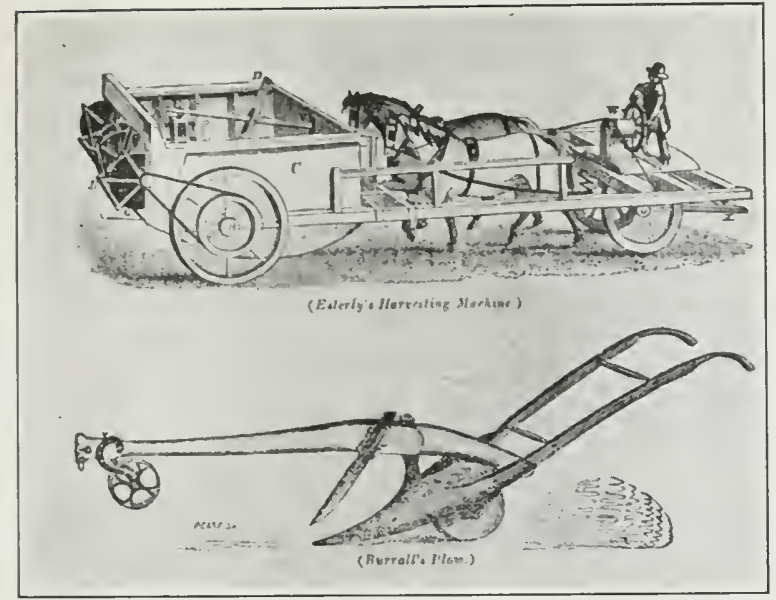

Above. AN EARLY PATTERN OF THE ESTERLY HARVESTING MIACHINE, $184 t$

Original in the MeCormick Library, Chicago

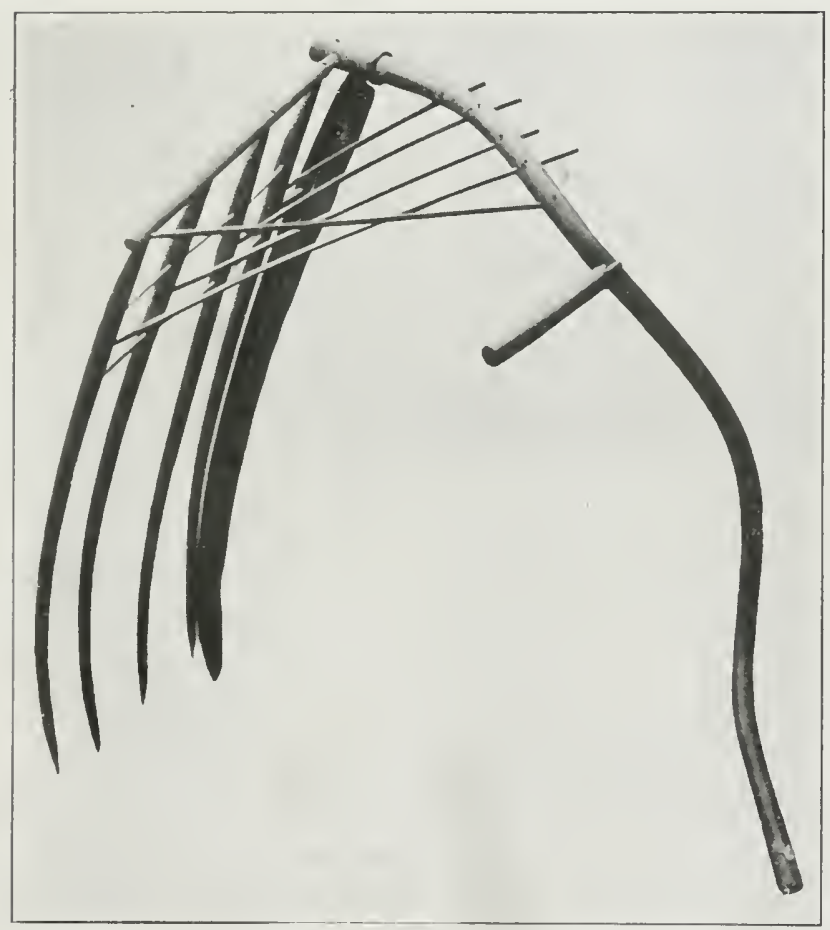

THE OLD CRADLE, OR "CRADLE-SCYTHE"

Original in the State Historical Museum 


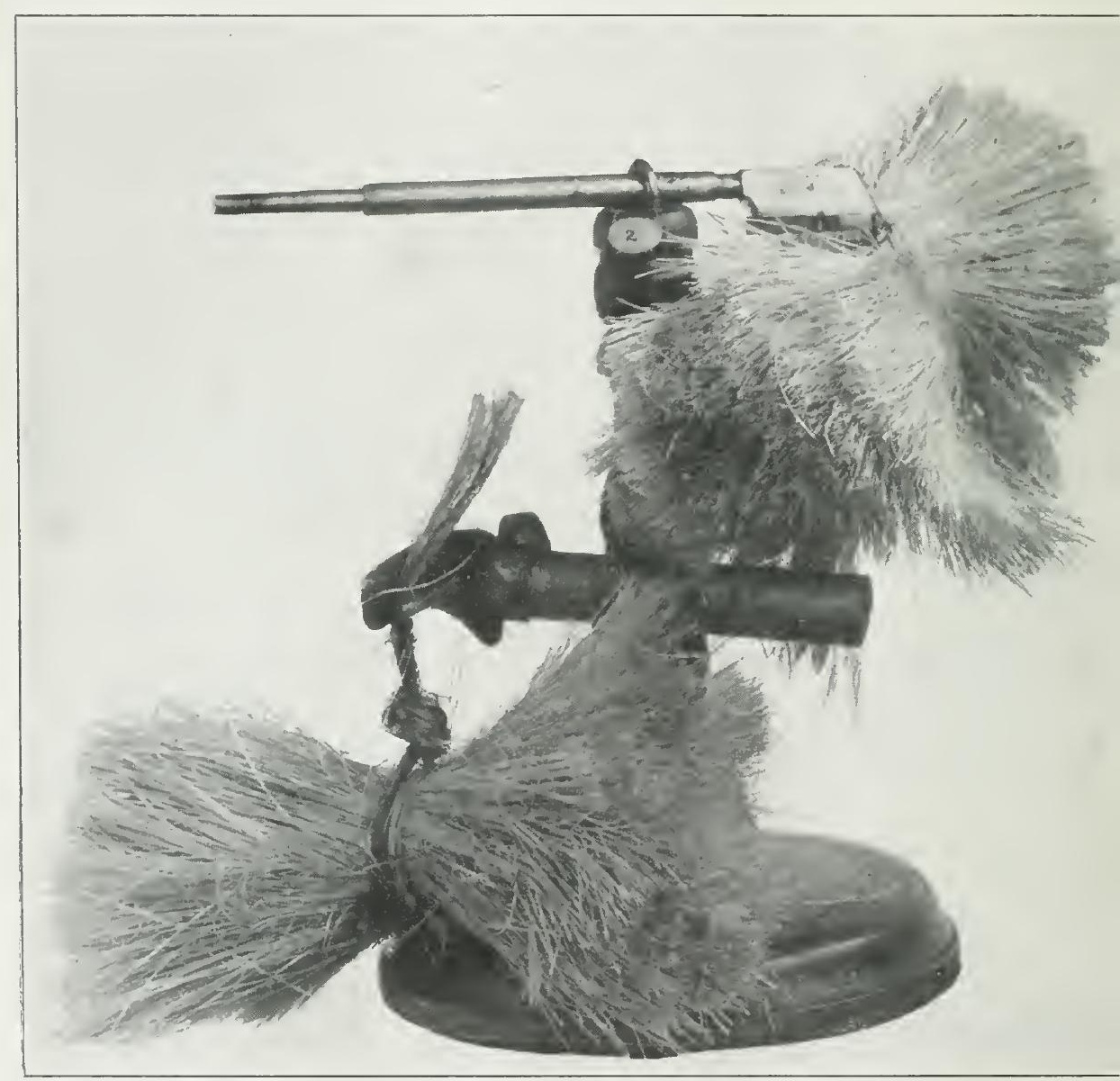

JOHN F. APPLEB Original in the State Historical Museum 
resources during the continuance of the war. Patriotism demanded that service. But after the war high prices combined with the hope of other bumper crops to maintain and expand the wheat acreage. Then not only rust, smut, and evil harvest weather-the ancient enemies of the wheat crop-but a new adversary, the chinch bug, entered the lists against the farmer, and all together rendered success in wheat culture far more doubtful than before.

The general course of "evolution and devolution" through which the business of wheat growing passed in southern Wisconsin between 1840 and 1880 is illustrated on the local plane from our study of selected towns scattered through the older counties. Our chart for 1850 lists ten towns which were treated statistically in the census schedule of that year. In two of these the average production of wheat per farm for the year 1849 was about 370 bushels, in one other it was 340 bushels, and in three others between 100 and 200 bushels. All of the high averages were in towns having prairie and openings, the low averages in wooded towns or those newly settled. An examination of the plats shows, by individual farms, the process of breaking up the land and raising wheat. It was going on through the census periods 1850, 1860, and 1870 in all of the towns. One Norwegian settler in Pleasant Springs, Dane County, who entered his land in 1844, produced, in 1849 , 300 ; in 1859, 600; in 1869, 2000 bushels, with 30, 75, and 200 acres out of 200 under cultivation at the intervals noted. A crop of 1000 bushels was by 1859 common among the settlers of that town, and many produced more. There were crops of 2000, 1700, 1500 in Bangor, La Crosse County, by 1859, though that settlement was less than ten years old. In Oshkosh Eli Stilson, in 1849, produced 900 bushels. He was then cultivating 80 acres. At the next census he had 280 acres and harvested 2300 bushels; and in 1869, with 1040 acres under cultivation, his wheat crop was 5000 bushels. A case from Mount Pleasant, Racine County, reverses the above. William G. Roberts produced, in 1849, 3500 bushels; in 1859, 1700; and in 
1869, 300. Sugar Creek in Walworth, Empire in Fond du Lac, Lodi in Columbia, and Plymouth in Rock County all show generous individual crops. The charts show that in 1859 Pleasant Springs (Dane County) had the highest average per farm, 452 bushels, with Bangor second, 436 bushels, and with Sugar Creek, Primrose, Lodi, and Empire each producing over 300 bushels per farm. Bangor lay in the Driftless Area, but the farms occupied the level floor and adjoining slopes of a fertile valley which was lightly wooded-practically level openings. The other leading towns were all in the glaciated area, with smooth, open lands and prairies. Bangor led all in 1869, her farm average being 642 bushels. Pleasant Springs was second, with 586; while Empire, Lodi, Muscoda, New Glarus, and Primrose each had over 300 bushels to the farm. It may be significant that the last three towns were in the Driftless Area, the farms usually occupying the valley lands. Thus it appears the primacy in wheat culture was already passing from the glacial prairies of the southeast, and the change was completed ten years later. For in 1879 only one town, Bangor, produced 400 bushels per farm, the former second-Pleasant Springs-dropping to 124 and Lodi to 104. On the other hand, Empire in Fond du Lac County had 376 ; Highland in Iowa, in the Driftless (with a heavy Knox silt loam soil), was producing 250 bushels per farm; Pulaski, adjacent to Highland, 202; and Muscoda, another near neighbor, a bare 200. The prairie towns had dropped to almost negligible figures, but Newton, in the forest of Manitowoc County, was coming to her own with 216, while Eagle had 183 and Castle Rock 187.

It is obvious that, so far as southern Wisconsin was concerned, wheat growing was at its last gasp by 1879 . The older counties had already generally abandoned it as the main crop, while in the newer settlements of the southwest, such as the dissected northern portions of Iowa and Grant counties, wheat was departing from the alluvial valley lands first broken up and was making its final stand on the ridges. The ridge 
soils were a stiff clayey loam (the Knox silt); they were of pure limestone origin and portions of them had been left with their original covering of small timber until about that date. Then, in order to lengthen out the life of the wheat crop, farmers cleared the ridge lands and for a few years raised fair crops, especially by adopting a rotation in which clover, sometimes treated with gypsum, was an important element. ${ }^{28}$

A study of the rank of counties in wheat specialization shows that Rock County stood first in 1849 , fifth in 1859 , and thirty-first in 1869. On the other hand, Green Lake, one of the newer counties bordering on Fox River, was first in 1859, while St. Croix, on the northwestern lobe of the lower magnesian limestone, was the leader in 1869 and 1879. Buffalo County stood first in 1889 and again in 1899. By 1870 Racine, Kenosha, Walworth, and Rock counties, the great wheat counties of the pioneer days, were down near the foot of the list; while St. Croix, Buffalo, and Trempealeau, in that order, headed the roll of counties. ${ }^{29}$ In the rich virgin lands of northern Wisconsin, which by 1880 were settling up rapidly, wheat continued to be grown for some years. But the change to a different type of farming, in which the wheat crop should be only incidental, was well under way everywhere in the region we described as southern Wisconsin.

No portion of the densely forested area attained distinction in wheat production. It proved impracticable, in the heavy woods, to clear land rapidly. The best erops of wheat could be grown on the newest land, while those lands which had been longest under cultivation were relatively better for other crops. Tillable land was not so plentiful at best as to encourage gambling on a single crop, and from early times the tendeney on such farms was to raise, in addition to wheat, a little of everything else. This policy prevented the forest settler

${ }^{23}$ The author can recall when ridge land was first broken up on his father's farm, about the year 1877. A German immigrant was employed, by the month, to grub out the young oaks and hickory trees. He could clear about five acres in a summer. The following May or June this would be broken up, four horses supplying the power. The process was continued till the "ridge field" occupied some thirty acres. This later became hay land and pasture.

${ }^{20}$ John G. Thompson, Wheat Growing in Wisconsin, Table iii, Appendix. 
from sharing in the opportunity for making money quickly which the prairie farmer found in raising big fields of wheat. But he had his reward later in a less exhausted soil which enabled him the more readily to take advantage of the new agriculture.

\section{SOURCES}

The most important single source for this chapter was John Giffin Thompson, Wheat Growing in Wisconsin. It is a capitally good study of the subject. 


\section{CHAPTER VI}

\section{DIVERSIFIED FARMING}

The period of thirty years between the seventh and tenth United States censuses, 1850 to 1880, witnessed not merely a great expansion in Wisconsin agriculture, but also a great readjustment in its fundamental character. In that interval, if we take the figures for 1849 and 1879, wheat production was multiplied 5.8 times-from $4,286,000$ bushels in 1849 to $24,888,000$ in 1879. But the last figure was about $4,000,000$ bushels less than the crop of 1860 . For some years both the acreage and the yield had varied widely and no such production record was destined to be obtained again. Wheat growing was on the decline.

On the other hand, corn and oats, which together amounted in 1849 to $5,403,670$ bushels, rose in 1879 to $67,140,900$ bushels -12.4 times the former amount. This increase was steady and unbroken. The corn crops of the four census years 1849, 1859,1869 , and 1879 were respectively $1,989,000,7,517,000$, $15,034,000$, and $34,230,578$, or an increase of $7,000,000$ bushels in the first ten years, 7,500,000 in the second, and $15,000,000$ in the third; while oats increased from $3,400,000$ to $11,000,000$, to $20,000,000$, and to $32,000,000$ bushels.

During the same thirty-year interval the hay crop was multiplied almost seven times-from 275,662 tons in 1849 to $1,907,430$ in 1879. That crop also had advanced regularly, by ten-year periods, even while the growing corn crop and the increasing use of corn stover or fodder were adding many thousands of tons yearly to the farm supply of roughage for stock.

With the proportional increase in grain and hay used for stock feed went the steady rise in the production of livestock -cattle, pigs, and horses-also of butter and cheese and, for a time, of sheep and wool. In other words, what the 
census reveals is a change from the one-crop system of wheat raising to diversified farming.

All of the products mentioned had been grown from the first, but so long as and wherever wheat remained the dominant interest they were merely incidental. Indian corn was usually the pioneer's first crop. After making his claim and building a cabin, he would break up a few acres of sod and plant his "sod corn." This he did by making ax-cuts in the overturned sod at regular intervals for the corn hills, dropping seed into the hills and stepping on them. The result not infrequently was a fair crop of corn for "roasting ears," for meal, and for grain to feed the oxen during the first winter. But, after the first season, when there was usually plenty of wheat for flour, corn was little used by settlers save in the form of "johnnycakes" or for a breakfast cereal. Neither the Northeasterners nor the European immigrants were fond of corn substitutes for wheat bread. The Southerners used it more freely, but they were not numerous. Besides, the Wisconsin climate was long supposed to be poorly adapted to corn growing, the state lying north of the great corn belt. Killing frosts sometimes destroy the young plants after they have come up, and more frequently the unripe crop is caught by frost in fall and is left "soft," in which condition it has little feeding value. As compared with the corn crops grown in Illinois, those of Wisconsin were insignificant. Yet, experience and science combined to improve the status of corn. Earlier maturing varieties were selected or bred, corn culture for this climate came to be better understood, the custom of cutting the standing corn and letting the grain ripen in the shock defended the crop somewhat against early fall frosts. ${ }^{1}$ Gradually it came to be understood that corn was as sure as any crop which the farmer could raise. On the dry prairie lands of the southern counties, on the rich, well drained openings, and on the alluvial bottoms it was much surer than wheat, and the yield per acre was generally much higher than

\footnotetext{
1 The breeding of resistant corn has been one of the triumphs eredited to the College of Agriculture of the University of Wisconsin.
} 


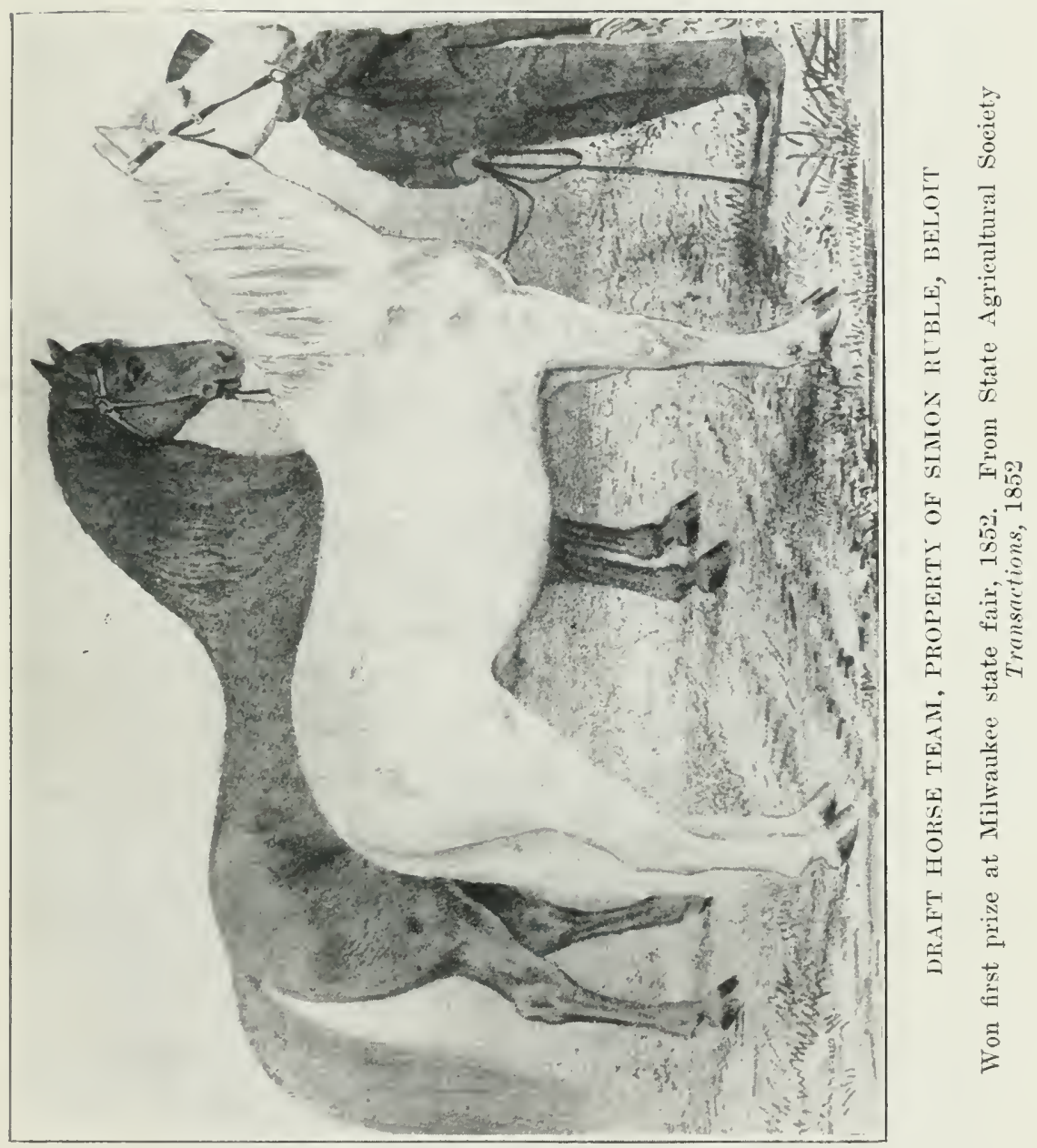




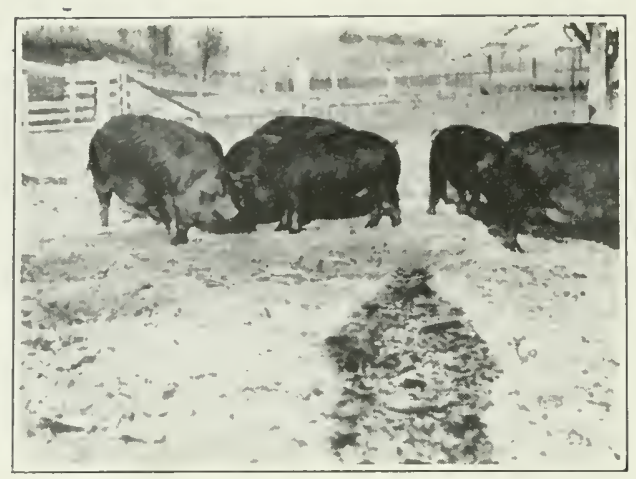

AN EARLT SUBSTITUTE FOR WHEAT ON WISCONSIN FARMS

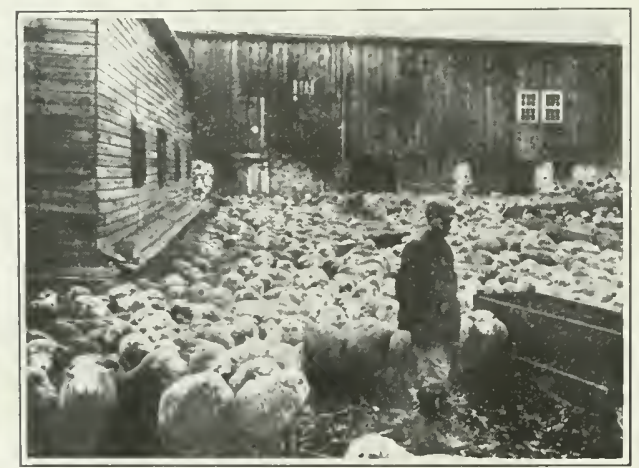

SHEARING TIIE ON A WALMORH COUNTY SIIEEP FARM 
the wheat yield. Wet lands, particularly if the soil was heavy clay, were less favorable, as were the stump infested fields of the heavily wooded area, where hoe tillage had to be employed.

The substitution of corn for wheat when the latter proved itself an uncertain crop was not immediate but gradual, as may be shown from our study of towns. For example, Mount Pleasant in 1849 produced on the average 375 bushels of wheat per farm, and only 102 bushels of corn; while in 1879 the same town was credited with 308 bushels of corn and 86 of wheat, thus reversing the relation of these two crops in thirty years. But, since the intervening two censuses show respectively 175 bushels of wheat to 93 of corn, and 110 of wheat to 157 of corn, it becomes clear that the great change occurred in the last decade, between 1869 and 1879. Other towns give results to substantiate the conclusion that farmers did not go into corn raising wholeheartedly until wheat raising had become demonstrably unprofitable, which, for southeastern and southern Wisconsin counties, was about $1870 .^{2}$

The census of 1880 showed five outstanding corn producing counties-namely, Rock (2,555,704 bushels), Lafayette (2,505,277 bushels), Green (2,187,550 bushels), Grant (3,408,034 bushels), and Dane (2,983,250 bushels). A secondary list, of counties credited with more than $1,000,000$ bushels, included Walworth, Iowa, Dodge, and Columbia. These were all large counties. The lake shore counties were all producers of small aggregate amounts of corn, though the two southern ones, Kenosha and Racine, which had much prairie land, and also Milwaukee, which had a high percentage of cultivated land by this time, produced their full quotas according to cultivated

'Plymouth, in Rock County, shows 346 bushels wheat to 131 bushels corn in 1849,231 to 200 in 1859,250 to 366 in 1869 . In 1879 the figures were 46 bushels wheat and 813 corn. Disregarding the comparison with wheat, the production of which declined in all the towns by 1880, we find corn production increasing in Sugar Creek from 86 bushels in 1849 to 143 in 1859, to 459 in 1869, and 1065 in 1879. In Empire the course of the corn crop is represented at the four census periods by the figures $36,24,60$, and 131 . Franklin had an average per farm of 30 bushels, 60 bushels, 143 bushels, and 183 bushels. Whitewater figures run 51 , 124, 222, and 620; New Glarus, 22, 173, 69, and 408; Norway, 14, 164, 10, and 230 bushels. 
areas. $^{3}$ The northern counties, whether wooded or open, raised but little corn. Brown had only a few thousand bushels, Manitowoc still less, while Winnebago and Fond du Lac had each somewhat more than half a million bushels. Some of the counties which were low in corn were still growing considerable wheat. That was true of Winnebago and Fond du Lac. The Mississippi counties, as far south as Vernon, were still raising wheat as their principal crop.

The history of oat production, as represented by our selected towns, shows that the range of that cereal was wider than the range of corn production. It was grown to a considerable extent everywhere; neither longitude nor latitude affected the crop, and the yield seems to have depended solely upon the quality of the soil and the type of culture employed. Strong soils produced heavy crops, light soils light crops. In 1879 Dane, the largest county, led in production of oats and was followed by Grant, Rock, Lafayette, Green, Iowa, Dodge, Fond du Lac, and Walworth in that order. Only Dane produced more than 2,000,000 bushels. The others named all had above 1,000,000 bushels, and Sauk, Vernon, Waukesha, and Columbia produced over 800,000 bushels each; while St. Croix, Racine, Manitowoc, Trempealeau, Sheboygan, Jefferson, and Kenosha exceeded 600,000 bushels. Considering relative

The best yields of corn among the counties named, in 1879 , were obtained in Kenosha, 412/3 bushels to the acre, and in Walworth and Lafayette, $39+$ bushels per acre. The lowest was in Columbia County, $321 / 2$ bushels.

There was some shifting of positions among the counties in the thirty years from 1880 to 1910 , yet on the whole the Wisconsin "corn belt" has remained fairly well outlined. Grant continued as the leader in 1890. In 1900 Dane, a county of larger area, took and held first place as to quantity of product, Grant being second but returning to first place in the recent census. In 1890 other counties, after Dane, were Rock, Isafayette, Green, Columbia, Iowa, Walworth, Jefferson, Dodge, and Sauk. In 1900 the succession was Dane, Grant, Rock, Walwortł, Green, Columbia, Dodge, Iowa, Jefferson, Sauk, Fond du Lae, Richland, and Waukesha. In 1910 it was Dane, Grant, Rock, Columbia, Lafayette, Dodge, Green, Fond du Lac, Jefferson, Iowa, Sauk, Racine, Outagamie, and Richland. The acreage in 1890 was $1,120,341$; in $1900,1,497,474$; and in 1910, $1,457,652$; and the total production $34,024,216,53,309,810$, and $49,163,034$ respectively. Up to 1910 no lake shore county is credited with as much as $1,000,000$ bushels of corn, but $1,000,000$ bushels for a small county like Racine was a high production record. 
areas, the three southernmost lake shore counties had the most generous oat crops and showed the best yields. ${ }^{4}$

In the growing of hay there were great differences among the towns compared, the average production per farm in 1849 ranging from 7 tons in Brookfield to 21 tons in Norway (Racine County) ; in 1859 from 5 in Eagle and in Castle Rock, both new towns, to 24 in Norway; in 1869 from 4 tons in Eagle and Castle Rock to 38 in Mount Pleasant; and in 1879 from 7 in Eagle to 41 in Mount Pleasant. The prominent hay producing towns at the date of the tenth census, in addition to Mount Pleasant, were Whitewater, Primrose, and Pleasant Springs, Norway, New Glarus, Franklin, and Empire. The counties represented by the above towns are Racine, Walworth, Dane, Green, Milwaukee, and Fond du Lac. At that census period Dane County was credited with 108,470 tons, Dodge with 93,076, Fond du Lac with 85,240, Walworth with 78,769, Rock with 76,205, Columbia with 71,991, Jefferson with 71,774, Green with 67,252, Waukesha with 63,388, and Grant with 62,951. Winnebago, Racine, Lafayette, and Iowa each had more than 50,000 tons, and Sauk had practically that amount.

The subjoined table shows the relation of the hay acreage to the acreages of oats, corn, and wheat in a list of 23 counties, and also the relation of wheat acreage ${ }^{5}$ to the combined acreages of these other crops. The proportion of wheat in the total crops varied from nine-sixteenths plus in the case of Dodge County to one-sixteenth minus in Lafayette. Five of the leading hay counties would also fall within a list of 15 leading wheat counties. These are Dodge, Fond du Lac, Dane, Winnebago, and Columbia. On the other hand, the counties of Lafayette, Green, Grant, Iowa, Rock, Walworth, Kenosha, Milwaukee, and Racine are among the low counties in wheat.

It is found that in 1880 Kenosha County had approximately 17,000 neat cattle, Racine 18,500, Milwaukee 12,000, Walworth 31,500, Rock 45,000, Green 45,000, Iowa 39,000, Grant 48,000,

- The best yield in Kenosha County, 412/3 bushels as an average.

${ }^{3}$ Including rye and barley. 


\begin{tabular}{|c|c|c|c|c|c|c|}
\hline County & $\begin{array}{l}\text { Cul. } \\
\text { Land }\end{array}$ & Wheat & Oats & Corn & Hay & $\begin{array}{l}\text { Market Ce- } \\
\text { reals- } \\
\text { Wheat, Rye, } \\
\text { Barley-to } \\
\text { Food Crops } \\
\text { in Acreage }\end{array}$ \\
\hline 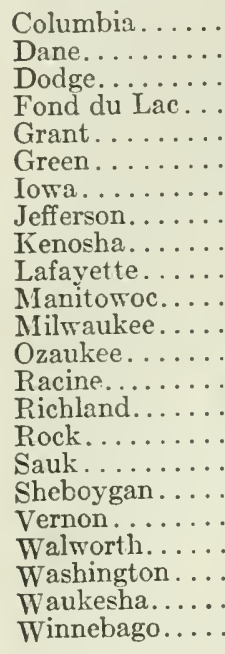 & $\begin{array}{l}232,406 \\
421,328 \\
436,689 \\
354,919 \\
409,377 \\
283,198 \\
256,677 \\
261,297 \\
176,415 \\
330,127 \\
200,477 \\
109,199 \\
103,232 \\
191,125 \\
131,145 \\
382,194 \\
222,642 \\
210,542 \\
178,759 \\
262,710 \\
189,707 \\
257,530 \\
213,533\end{array}$ & $\begin{array}{r}71,525 \\
89,911 \\
142,809 \\
112,201 \\
41,663 \\
11,774 \\
29,896 \\
34,594 \\
5,663 \\
9,167 \\
60,8946 \\
11,732 \\
30,083 \\
13,481 \\
21,162 \\
23,212^{7} \\
40,714 \\
45,407 \\
51,316 \\
26,080 \\
50,012 \\
42,638 \\
56,627\end{array}$ & $\begin{array}{l}24,334 \\
67,099 \\
28,202 \\
26,371 \\
60,443 \\
37,166 \\
37,670 \\
17,051 \\
14,654 \\
49,997 \\
23,732 \\
11,573 \\
12,464 \\
18,016 \\
11,564 \\
52,528 \\
26,863 \\
18,142 \\
24,810 \\
26,305 \\
15,361 \\
19,755 \\
14,957\end{array}$ & $\begin{array}{r}39,308 \\
86,897 \\
29,642 \\
21,416 \\
98,898 \\
59,745 \\
47,287 \\
27,089 \\
15,344 \\
63,926 \\
668 \\
6,566 \\
2,940 \\
15,042 \\
25,480 \\
74,835 \\
32,124 \\
8,813 \\
21,655 \\
40,332 \\
12,263 \\
23,333 \\
15,075\end{array}$ & $\begin{array}{l}49,620 \\
76,669 \\
64,918 \\
66,242 \\
46,297 \\
44,390 \\
35,104 \\
52,546 \\
37,886 \\
34,618 \\
31,969 \\
26,533 \\
17,040 \\
43,344 \\
22,018 \\
53,160 \\
36,160 \\
36,459 \\
26,753 \\
54,108 \\
27,324 \\
51,180 \\
48,143\end{array}$ & $\begin{array}{r}84-123 \\
115-230 \\
157-117 \\
124-113 \\
46-204 \\
12-141 \\
30-120 \\
48-96 \\
56-670 \\
9-148 \\
70-54 \\
21-44 \\
37-32 \\
13-76 \\
21-58 \\
23-180 \\
40-95 \\
59-63 \\
51-72 \\
36-120 \\
62-54 \\
57-94 \\
56-78\end{array}$ \\
\hline
\end{tabular}

Lafayette 40,000. Dane County, whose area is more than four times that of Racine, had 59,000; Dodge, thrice the size of Racine, 48,000; Columbia 33,000; Fond du Lac 38,000; Jefferson 35,000 ; and Waukesha 25,000 .

It is clear that the cattle interest was pursued most intensively in the southeast, the south, and the southwest. The impression that animal husbandry had largely supplanted wheat growing in that area is deepened when we combine with the statistics of neat cattle those relating to horses, sheep, and

- Manitowoc County also had 5396 acres of rye. Other rye producing counties in this list were: Columbia, 5656 acres; Dane, 5555; Grant, 4827; Jefferson, 4116; Milwaukee, 3468; Ozaukee, 2415; Rock, 8390; Sauk, 5264; Sheboygan, 4992; Washington, 4989; and Waukesha, 5344. In other cases the acreage is negligible.

'Rock County had a erop of barley grown on 23,420 acres. Other counties in this list had areas of barley as follows: Columbia, 6547; Dane, 21,361; Dodge, 15,049; Fond du Lac, 12,075; Jefferson, 9868; Manitowoc, 5290; Milwaukee, 7036; Ozaukee, 5262; Sheboygan, 9445; Walworth, 9679; Washington, 7448; Waukesha, 10,209. Others have small areas. 
swine. For example, Racine had 48,000 sheep, Dane 81,000; 14,362 swine, Dane 96,$000 ; 6684$ horses, Dane 22,150. In sheep and horses Racine greatly exceeded her proportion, in swine she fell below. In sheep Walworth County was first in number, and also first in intensity, with Kenosha, Racine, and Wankesha following in her wake, and Fond du Lac a trifle further behind. Grant County had the largest absolute number of swine and Dane the second largest; but Lafayette and Iowa, together about the size of Dane, showed a higher intensity than either of these. In general, swine were plentiful in the corn counties and scarce in the wheat counties.

To summarize: We find that, by 1880 , the counties of the older Wisconsin may be divided into two groups. The first was that in which the growing of feeding crops-corn, oats, and hay, or any two of them-predominated very much over the market cereals-wheat, rye, and barley. The second was that in which the market cereals still occupied a larger area of the cultivated lands than the crops ordinarily raised for feeding livestock. Taking Dane County as our norm, we find there two acres of other crops to every acre of the market cereals. Jefferson County, lying on her eastern border, was on precisely the same basis, while Sauk, Grant, Richland, Crawford, Green, Lafayette, and Iowa, her neighbors on the south and west, had a much lower proportion of their lands in market cereals, and the same may be said of Rock, Walworth, Racine, and Kenosha counties. Milwaukee was in the same situation with Dane; Waukesha was somewhat more favorable to the market cereals though her acreage of these was still far below that of the feeding crops. On the other hand, the counties near the lake shore north of Milwaukee-Ozaukee, Washington, Manitowoc-also Fond du Lac, Dodge, and Columbia farther west, were distinctly favorable to the market cereals, while Sheboygan and Winnebago leaned slightly to the other side.

A line drawn from Lake Michigan along the north boundary of Milwaukee, Waukesha, and Jefferson counties, thence by 
the north boundary of Dane County to the Wisconsin, and including the counties of Sauk, Richland, and Crawford north of the river, would establish the northern limits of the distinctively feed producing area in 1880. Finding as we do that livestock production in those counties harmonizes with the above conclusions, we are safe in describing this as the area in which diversified farming has made most progress. ${ }^{8}$

Both the systematic beginnings and the fundamental conditions of this new development are revealed in the story of the first successful state agricultural society. Various attempts to organize a state society on the model of New York and other eastern states had failed. Finally, in March, 1851, members of the legislature and other prominent citizens met in the capitol and effected an organization which immediately began to function and has proved permanent. ${ }^{9}$

In his first report the secretary of the society makes it clear that the state had no choice but to organize for the improvement of farming conditions, and to utilize the results gleaned elsewhere to promote better farming here. He says: "Organized in a new state, with a sparse population, our farmers nearly all in moderate circumstances and of limited means, suffering under the failure of our staple crop for the past three years, and in a time of unexampled pecuniary disaster, and agricultural depression, we have no time to wait for a long preparatory training; and it becomes to us a matter of necessity, that this Society-Minerva like-shall at once step from birth to maturity."

Acting under such convictions, the society raised funds by private means for holding a fair and cattle show, which occurred at Janesville in October. The society also encouraged

- In the report of the first state fair, held at Janesville in October, 1851, it is stated that "none of the western counties had any specimens on the ground, and the northern counties but few.'" Counties strongly represented were Rock, Dane, Walworth, Racine, Kenosha, and Milwaukee; less strongly, Waukesha, Jefferson, and Dodge. Wis. State Agric. Soc., Trans., i, 16.

- Erastus W. Drury of Fond du Lac was made president; Albert C. Ingham of Dane, secretary. Vice presidents were Roswell C. Otis of Kenosha, Henry M. Billings of Iowa, and William F. Tompkins of Pock. See Wis. State Agric. Soc., Trans., i, 10, 95. 
the organization of county societies, of which several modeled after the Berkshire County, Massachusetts, fair, founded in 1810 by Elkanah Watson, already existed. 'The secretary was instructed to assemble material for a volume of transactions, in the expectation that it might be published at state expense.

The principal part of this first volume, which appeared in January, 1852, consisted of a series of papers by local men, in the nature of surveys of agricultural conditions in the counties. In that series all the counties of the older Wisconsin were reviewed, save Milwaukee and Calumet on the east and the lead counties in the southwest. ${ }^{10}$ The tone of the writers was one of discouragement with wheat raising, but just as uniformly they exhibited a reserve of optimism based on the hope that agriculture would now promptly change from the wheat basis to a more diversified type of industry.

Their summarized testimony showed that only the smallest beginnings of general farming, crop rotation, and especially livestock production existed at that time in most of the counties. Crops other than wheat were mainly corn and oats, but they were grown on a very small scale. Potatoes, stricken with the rot a few years earlier, were almost a complete failure at that period; and while other roots, like carrots, turnips, and rutabagas, could be produced with both ease and success, very few farmers took the trouble to raise them or had much occasion to use them for feeding. In some sections barley was grown for market, in others rye, but these crops merely tempered the effort to grow as much wheat as possible. Nearly all the hay that was gathered, at least in the counties away from the lake shore, came from the natural wild-grass meadows or marsh lands. In Kenosha and Racine a movement was on foot to change the wild meadows into tame-grass meadows, and there was also some interest in the growing of clover and timothy on cultivated lands. Such experiments, however, were as yet sporadic.

From nearly all counties came the complaint that local dairy products were insufficient to meet local demands, that much

${ }^{20}$ In addition, there are papers on St. Croix, Crawford, and Sauk counties. 
cheese and butter had to be imported from other states and sold here at high prices. Reasons for the failure of farmers to give more attention to dairying were said to be a want of appreciation of its benefits, a lack of the means necessary to procure cows and equipment, and (among many of the foreign born) a want of knowledge of the processes of cheese and butter making. A more potent cause, however, as pointed out by a Dane County writer, ${ }^{11}$ was the universal habit farmers had of depending on the wild grasses for pasture feed. These were good for ten or twelve weeks in late spring and early summer, but when grazed down in the later summer no new growth would start in the fall, and such of the earlier growth as might be left was both unpalatable and unproductive of milk, while the pasture was permanently depleted by cattle during the dry season tearing out roots of the grass. In a word, the "flush season" was a very short one, and during the greater part of each year milch cows were a care, a nuisance, but not a source of profit. He was a far-sighted farmer indeed who deliberately planned, by sowing clover and other grass with his grain crops, to have good late summer and fall pasturage for his cows, and yet that was the only method by which dairying could be made to pay. Only in Kenosha and Racine counties, and to a less extent in Milwaukee and Walworth, was dairying carried on under conditions guaranteeing success, and even there the number of experimenters was extremely small. Nearly every farmer had a few head of cattle, including cows, but as a rule they were a poor class of "scrub" stock and they received wretched care. From many sources we learn that it was almost the universal practise to let cattle "rustle" for a living both summer and winter. At best their winter shelter was a straw-roofed shed and their feed the straw from the wheat crop and perhaps a little coarse slough hay. The pitiful spectacle of cattle humped and shivering around the farm yard in the coldest days and nights of Wisconsin's bitterest winters was so common as to be considered

"John Y. Smith. 


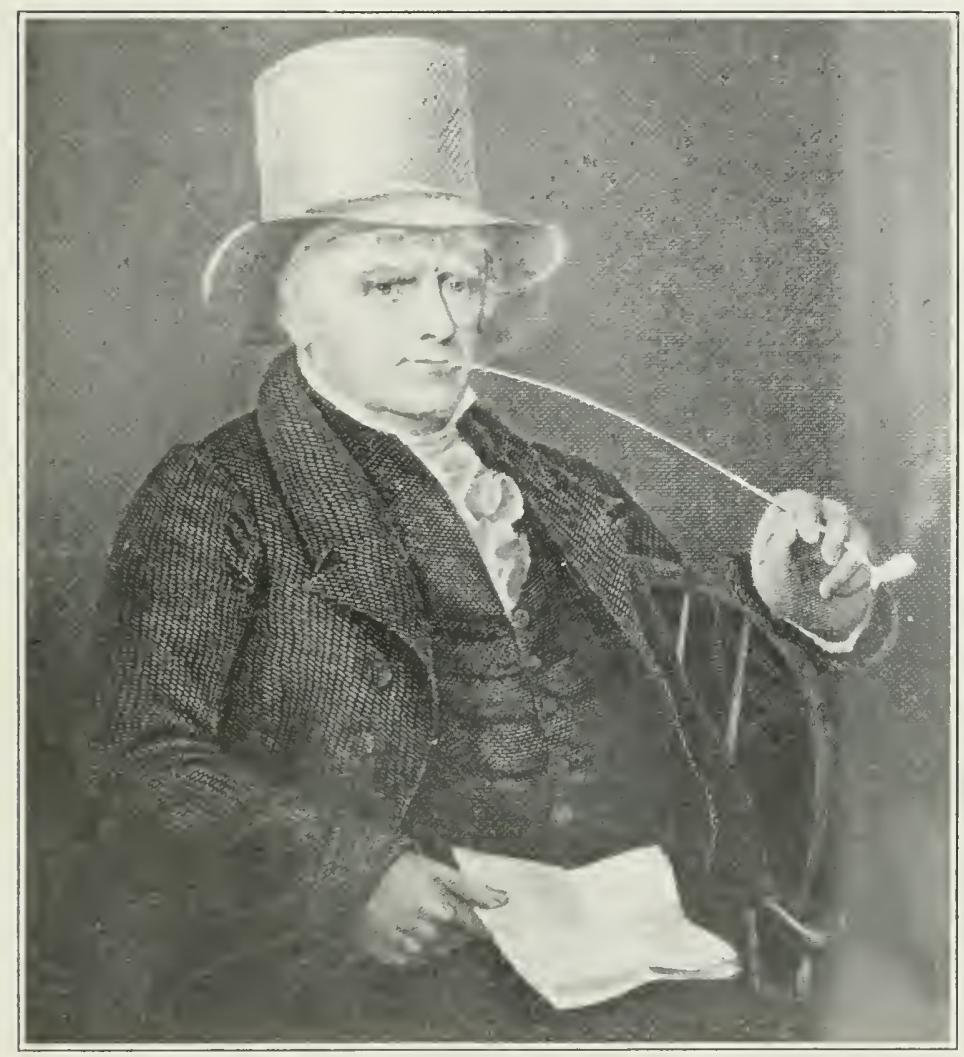

ELKANAH WATSON

Founler of the Berkshine County Fair, 1s10, and promoter of New Tork state and comty fairs 


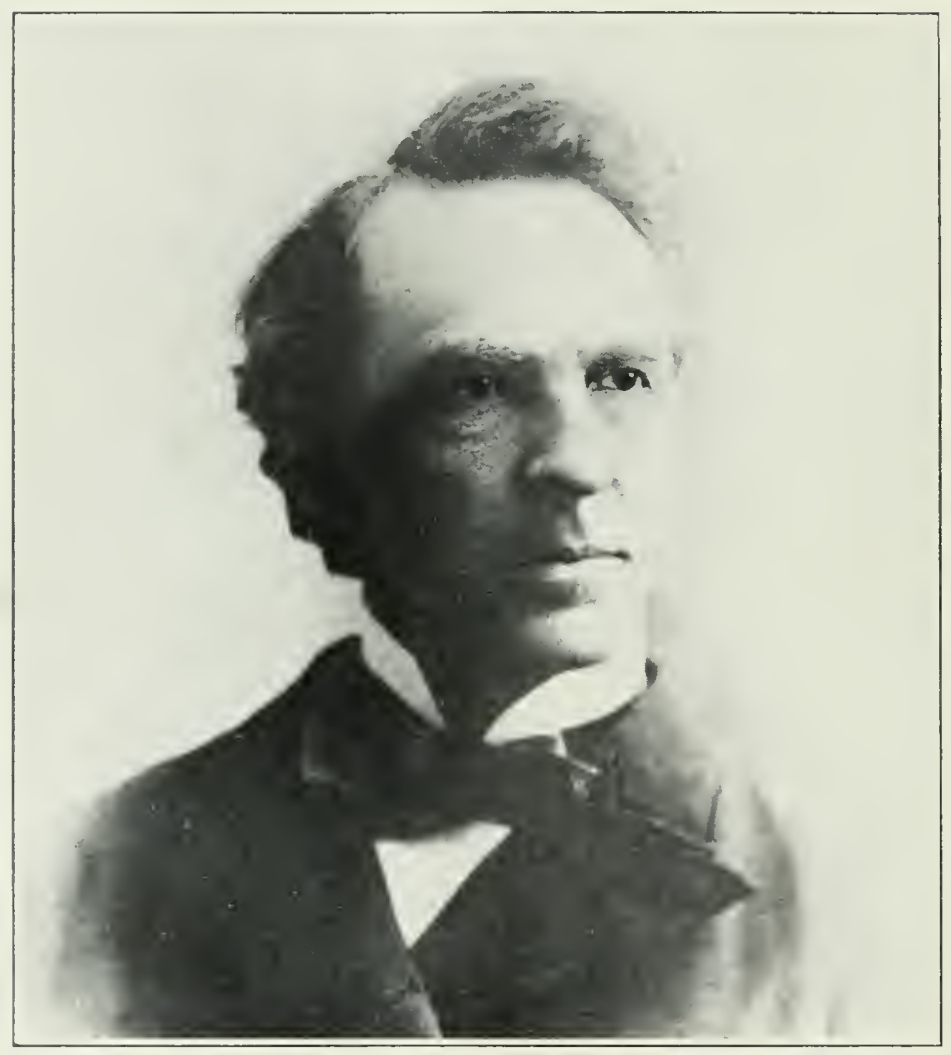

JOHA WESLEY HOYT 
the rule. There were only occasional exceptions. Under these circumstances, little or no advantage was taken of the barnyard fertilizer which might have been derived from the farm livestock. The work horses alone, when there were such, and the working oxen were regularly stabled and more or less regularly fed and cared for, and the manure from these was often a small part of what might have been available for crops if all livestock had been properly stabled and generously fed and bedded.

Sheep were not yet numerous, but considerable interest was manifested in them and a number of good-sized flocks, some as large as 700 to 1000 head, were to be found in the southeastern counties, particularly Kenosha, Racine, and Walworth. Most of the sheep, like the cattle and the pigs, were derived from stock brought in by drovers from southern Illinois and Indiana. Almost every farmer had a few pigs for a home supply of pork. A small amount of barreled pork was sold to the pinery and some was shipped from the lake ports; but the business of pork raising was in its infancy. The prairie counties were passing from the use of oxen for farm work to the use of horses. This general change, supposed to represent a fundamental economy-horses moving so much faster at their work-produced a rather widespread market for good farm horses, and some attention was given to their breeding. It was the southeastern counties which led in that line, as well as in sheep, in cattle, in tame grasses, in crop rotation, and in all efforts to underprop an agriculture made sick by the long continued cropping of the lands with wheat.

Doubtless it was significant of the sentiment in that region that the first agricultural journal to be published in Wisconsin had its birth in Racine. This was the Wisconsin Farmer and Northwestern Cultivator, issued by Mark Miller in January, 1849. Under various modifications of title, with numerous changes in editorial management and in character, this journal has persisted, though not continuously, to the present time. Its announced purpose was to assist farmers, through a modi- 
cum of "book knowledge," to understand the "capabilities and deficiencies of the soil, and how it may be improved-the proper rotation of crops-the right application . . . of manures," etc. The editor emphasized the necessity of livestock, the dairy, tame grasses, soil analyses, and soil treatment. ${ }^{12}$ $\mathrm{He}$ advocated deeper and more thorough cultivation, cheaper fencing (Dr. Hoy wrote some articles on a "living fence," which meant hedge fence), better stock shelters, more attention to making salable butter and cheese, wool growing, and pork raising. He also urged the organization of county and state agricultural societies.

In 1857 John Wesley Hoyt, an Ohio man of twenty-four years, who had been educated in medicine but had turned his chemical studies to account as a teacher of agriculture, came to Madison as assistant editor of the Wisconsin Farmer, which then and afterwards was published at the capital. Dr. Hoyt, in 1859, was elected secretary of the Wisconsin Agricultural Society, and early in 1860 he assumed in addition to his former duties the sole editorship of the Farmer. Hoyt's editorials, from his first appearance in Wisconsin, began to influence the thought of the people toward a more scientific view of agricultural problems. He also lectured extensively on scientific agriculture, covering, in two or three years, most of the settled portions of the state, performing in this way a service analogous to that performed by the later farmers' institutes. In 1860 he proposed the name "farmers' institute" for a month's lecture course for farmers, which he offered to arrange if farmers desired it. The institute was not held, but at the time set for it Yale University held the first farmers' course given on a collegiate basis in America. Hoyt continued to edit the Farmer till 1867, and remained as secretary of the State Agricultural Society till 1872. He was a vital influence during fifteen year's in developing a sentiment for better farming, for agricultural education, and for agricultural organization. He died in 1912, at Washington, D. C.

\footnotetext{
${ }^{12} \mathrm{He}$ printed articles on soil analysis and other subjects, from the pen of the distinguished physician-scientist Dr. Philo R. Hoy of Racine.
} 
From the time of Dr. Hoyt's arrival, and even from the founding of the Farmer, the people of Wisconsin were never permitted to worship unmolested their golden idol wheat. Yet, as crops and prices improved together, beginning in 1853 , with railway transportation to add another increment of value to every bushel grown, it is not surprising that the movement for diversified farming for some years should have made but slow and halting progress. Several money making specialties were introduced which gained some currency. Chief among these were tobacco, hops, and sorghum. The first, begun at least as early as 1840, had a gradual development for some years and finally established itself as a regular feature of Wisconsin agriculture. ${ }^{13}$ Hops had a meteoric career in this state as in some others, but about 1869 the drop in price to a point below the cost of production led to the plowing up of the hop yards in Sauk, Dane, Richland, and the other counties where the business had been most largely developed, and the substitution therefor, at least in some cases, of a new type of dairying. ${ }^{14}$

The growing of sorghum was followed in a small way before the Civil War. During that crisis time the patriotic motive of affording the nation an independent supply of sugar called out extraordinary efforts, both in Wisconsin and in other states, to expand the area of the crop and to develop facilities for making sugar. "Sorghum conventions" were held annually; the agricultural press teemed with advice about sorghum culture, preparation of soil, high quality seed, planting, cultivating, harvesting, and the machinery required for sugar making. A goodly proportion of Wisconsin farmers experimented with it and the result had some influence upon the sugar supply. But with the close of the war, when access was gained once more to the cane-sugar growing areas of the South, the crop dwindled to insignificance. However, the

\footnotetext{
${ }^{10}$ See Benjamin H. Hibbard, History of Agriculture in Dane County, Wiscon$\sin$ (Madison, Wis., 1904), chap. iii, pt. 2.

${ }^{14}$ Hibbard has an admirable summary of the hop business in chap. ii, pt. 2. Sce also Frederick Merk, Economic History, chap. i.
} 
knowledge of sorghum growing and syrup making persisted, so that during the recent war sorghum revived in a noticeable manner as an emergency crop.

Among the features of the better-farming program preached by all farm journals, perhaps none prospered more during the later years of the wheat growing era than growing of tame grasses, especially clover. Farmers once habituated to the sight of the clover plant as a supplementary crop drilled in with the wheat seed and, after the removal of the grain, pastured and then either permitted to produce hay and seed or plowed under as a green manure, could not long blink its benefits, and it spread from farm to farm and from county to county. Also, the use of gypsum as a stimulant to the growth of clover spread in like manner, and in many districts the custom became general of "seeding down" portions of the cultivated land with clover and timothy either for pasture, for seed, or for hay in a rotation. This in itself was no slight benefit to agriculture.

A shift from wheat raising to dairying always involved the use of considerable capital. When times were hard, capital for the purpose was wanting. On the other hand, pork raising could be entered upon with a very small initial outlay for breeding stock. Experience had demonstrated the success of corn as a crop in most portions of the older Wisconsin, and the habit of growing it to a small extent was almost universal. All that was needed, when wheat became doubtful or a proved failure, was to expand the area of corn and the area of clover pasture for pigs, to keep a few breeding animals, and to raise and fatten hogs. The markets could be easily reached by means of the new railways, and moreover, where swine were raised at a considerable distance from the railway they could be driven to the shipping point much more cheaply than wheat could be hauled to the same point. ${ }^{15}$

${ }^{25}$ The "prairie farmers" in Grant and Iowa counties in the days before the completion of the Northwestern Railway along the Military Ridge, used to drive their hogs 25, 30, or 40 miles to stations like Boscobel, Muscoda, and Aroca on the Prairie du Chien line. 
In these ways, although in the years 1850 to 1870 no startling revolution in favor of diversified agriculture can be observed, circumstances were forcing the change by little and little. Meantime, a widely read agricultural press was preaching the doctrine unremittingly, the state and county fairs were demonstrating its benefits to the multitudes, while every successful general farmer, sheep farmer, or dairyman was a means of spreading it through his own community first, and sometimes of exerting a wider influence.

In this connection one ought not to overlook the steady condemnation of bad farming methods involved in the patient, plodding devotion to the principles of good tillage exemplified by thousands of the emigrants from older countries where a more intensive type of agriculture had been compulsory. These people proved to the devotee of extensive farming that it often paid to employ fewer acres and to plow deeper, utilize all fertilizing material, and grow clover with the aid of g.psum. They were undaunted by the labor involved in grubbing, so they cleared out all stumps from their fields instead of cultivating round them. They generally cared well for such livestock as they kept and, in a word, were object lessons in better farming on several fundamental points inculcated by tradition. When, however, it became a question of change to a type of farming better adapted to the time and region, leadership at first was provided mainly by American farmers.

\section{SOURCES}

The two main sources for this chapter are the Transactions of the Wisconsin State Agricultural Society, which began to be printed in 1851, and the Wisconsin Farmer, whose publication was begun in 1849. But Hibbard's admirable History of Agriculture in Dane County, Wisconsin, was also very useful, as were the Domesday Book Town Studies. 


\section{CHAPTER VII}

\section{IMPROVED LIVESTOCK}

Diversified farming, in so far as it involved a new emphasis on animal husbandry, introduced our farmers to the neverending discussion of livestock improvement-of breeding, as well as feeding. In this respect, as in the matter of wheat raising, the settlers coming to Wisconsin from the eastern states brought with them favorable traditions.

The generation which came upon the stage after the close of the War of 1812 began the regular reading of agricultural periodicals, and these adopted improved livestock as a primary feature of the better farming campaign. The same generation began attending county fairs and state fairs. Moreover, it was just at that time that importations of purebred animals from abroad began to influence strongly the efforts of breeders in America. The American line of purebred Devons is traced back to the Patterson importations of 1817 and the years following. Shorthorns that are eligible to herd book registry rarely if ever go back to importations earlier than those of 1818. In fact, it was in the years 1818 to 1840 that this country acquired from England the beginnings of those herds, of choicest strains, which made some of the breeders in New York, Pennsylvania, New Jersey, Kentucky, Ohio, and Illinois almost as celebrated for their shorthorns as were formerly the Collings brothers, the Reverend Henry Berry, and Thomas Bates in England. There were earlier importations of animals of both the above breeds, but they attracted little popular interest; they failed to result in a persistent program of pure breeding or to exert a large influence toward improving the livestock of the country or even of a single state. ${ }^{1}$

It was during the later years of the Napoleonic wars that Spain was compelled to give up her monopoly in merino sheep,

"Among the cattle brought to the colonies were many Old Devons-the "red oxen" of New England; and there were probably some of the ancestors of the improved Durhams or shorthorns. 
and from the importations of Consul William Jarvis in 1809, 1810, and 1811 the flock masters of Vermont and other states mainly supplied themselves with breeding stock. A few merinos had already reached the United States from France, particularly through the efforts of Chancellor Livingston, but the great movement for improving the wool industry dates from the Jarvis importation. Improved Leicesters, Cotswolds, Southdowns, and other English breeds followed rather than preceded the merinos.

In the matter of swine, experimentation with improved breeds began to be common during the same general period. In this department, also, American breeders built on the achievements of the English, who had produced their improved Suffolk, Essex, Yorkshire, Cheshire, and Berkshire breeds, all of which, together with the China pig and some others, were brought to this country and quickly gained popularity among the better farmers.

The state and county fairs were peculiarly adapted to promote a general interest in improved breeds of livestock. Good cattle, sheep, pigs, horses, and poultry really made the fairs. In fact, the county fair was first suggested in Elkanah Watson's exhibition on the village green of Pittsfield, Massachusetts, in 1807, of two merino sheep. ${ }^{2}$ Always and everywhere it was the livestock exhibits that attracted farmers to the fairs and gave them such success as they had from an agricultural point of view.

When in the fall of 1851 the first Wisconsin state fair was held at Janesville, the State Agricultural Society made a special effort to secure a good showing of livestock, and they were reasonably successful so far as number of entries went. There were 52 entries of cattle, 68 of horses, 120 of sheep, and 20 of hogs. Among the cattle 12 are classed as shorthorns, 12 as Devons. The rest were "natives and crosses." What the breeding of the shorthorns and Devons may have been we do not clearly know. We do know, however, that the exhibitors'

${ }^{2}$ See Elkanah Watson, History of the . . Berkshire Agricultural Society, in Massachusetts (Albany, N. Y., 1819). 
names do not appear in the American Shorthorn Herd Book of nearest dates. Possibly not a single registered shorthorn or Devon animal was owned in Wisconsin at that time. Since, however, several exhibitors had family names which tally with those of contemporary shorthorn breeders in other states, it is not unlikely that the animals credited to them had been consigned for the purpose of being exhibited and sold in Wisconsin. Some of the animals also may have been "full-bloods," so-called, though not eligible to registry. ${ }^{3}$ Six each of the shorthorns and Devons were exhibited by an Illinois breeder.

The same query about purity of blood arises in relation to the exhibits of horses. No distinct breeds are mentioned. The animals are listed under three heads: horses, matched horses, and geldings. In only a single case, that of $\mathrm{R}$. M. Wheeler's stallion "Hambletonian," was the pedigree referred to. In that instance a letter was placed in evidence from the Vermont breeder who sold the animal to Mr. Wheeler. He claimed to give the pedigree fully on the sire's side, incompletely on the side of the dam. This animal was evidently fairly well bred, but nothing can be asserted with confidence of the others.

The sheep were grouped under six heads: long wool, middle wool, merino, Saxon, paular merino, and crossbreeds. The long wools were all "Bakewell sheep,"' which means improved Leicesters. Middle wools included Southdowns and Leicesters. The merinos, Saxons, and paular merinos were probably purebreds. Mr. N. B. Clapp of Kenosha County certified that his breeding stock, Saxons, came from the importations of H. D. Groves of Hoosac, New York, and that he purchased them in the year 1844 in Dutchess County, New York and Litchfield, Connecticut. The paular merinos were brought from Vermont. ${ }^{4}$ Other merinos were probably of Vermont origin, nearly all of which belonged likewise in Kenosha

\footnotetext{
- See S. P. Lathrop's statement in Wis. State Agric. Soc., Trans., 1855, 26. There are no Wisconsin shorthorn breeders listed in Lewis F. Allen, The American Herd Book, i, publisher in 1846.

-Wis. State Agric. Soc., Trans., 1851, 14.
} 
County. Among the exhibits of swine one is called a Berkshire, one a Byfield, one a Leicester, and a fourth a Neapolitan. In other cases the breed is not designated and nothing is said about purity of blood.

Considering the exhibition as a whole, there is no doubt that in the interest of Wisconsin farmers sheep held at that time highest place among improved livestock, while swine held the lowest place. Cattle and horses were merely of that degree of respectability which argues a rather languid interest in their improvement. The exhibits of shorthorns by Wisconsin men all came from Racine and Walworth counties, save one which was from Rock; while the Devons with one exception were from a single herd at Fox Lake, in Dodge County. Of course, in those pre-railway times distance and conditions of travel influenced very markedly the geography of the exhibits.

It is not to be inferred, from what has been said, that there were probably no good cattle in the state at that time. Indeed, evidence independent of the Transactions proves the existence from early times of improved cattle, particularly in Racine, Kenosha, and Walworth counties. But circumstances had hindered those who tried to improve their stock. Generally speaking, cattle grazed, as commons, the untilled lands in nearly every neighborhood. The herds mingled together indiscriminately, thus preventing careful, determinate breeding from selected sires. This evil continued till practically all the lands were taken up and enclosed, after which the herds were effectually separated. ${ }^{5}$ Since the prairies and openings of the southeastern part of the state were earliest brought into farms and enclosed, it was there that progress in livestock improvement first became practicable.

Passing over the intervening years until we reach the exhibits of 1860 , we find 22 shorthorns receiving awards and several others "honorable mention." The most prominent exhibitors were Richard Richards and John P. Roe of Racine.

- It was many years before public opinion demanded and enforced a law which forbade owners to allow bulls to run at large. See Wisconsin, Laws of 1870 , chap. 93. 
County, Seymour Brooks of East 'l'roy, Walworth County, and C. H. Williams of Excelsior, Sauk County. All of these men were at that time recognized breeders of registered stock. According to the Herd Book of 1859, Richards was owner of 4 pedigreed bulls and 6 cows. Roe had 3 pedigreed bulls and 5 cows; while Brooks had, in 1859, 1 bull and 1 cow $^{6}$ and Williams 1 bull and 5 cows. ' None of the other exhibitors of 1860 are named in the Herd Book, though several other Wisconsin breeders appear in it. By that time we can claim for Wisconsin a definite status in the breeding of purebred shorthorns, and we find equally good evidence to prove the interest in Devons. There were also, among the cattle, a few Alderneys, Ayrshires, and Herefords.

After 1860 the breeders of shorthorn cattle increased very rapidly in numbers and also became widely distributed over the state. It is not possible, in this brief sketch, to notice many individuals. Racine County continued to hold a very prominent position. Richard Richards, who was in 1859 one of the best known Wisconsin shorthorn breeders, increased his herd gradually until by 1866 it counted 24 head of registered stock. But he dropped out of that department shortly after 1870, devoting his energies and great ability to the breeding of fine horses and fine pigs. Mr. George Murray of Racine was owner of a group of shorthorns which, under the name of the Slausondale Herd, was famed not merely in Wisconsin but all over the country as one of the choicest herds in Amer-

- Mr. Brooks, who was the son of a successful New York breeder, had a dispersal sale in June, 1857, and presumably sold most of his herd of 25 mature ghorthorns and 20 calves. See Wis. Farmer, 1857, 213-214, 223. His herd was described by the editor of the Farmer as "undoubtedly the largest and best bred herd in the state." He adds: "If scattered through the different counties and used judiciously, it will tend to materially improve our stock." It must be noted that though the Herd Book of 1857 fails to eredit Seymour Brooks with any reg. istered animals, his bull "Samson," No. 2172, winner of the first prize at the state fair at Milwaukee in 1856 and at Janesville in 1857, is credited to William Ellsworth of Mayfield, Cuyahoga County, Ohio. This is an instance to show how slowly the records adjusted themselves to changes of ownership and it suggests that Brooks's entire herd were probably Herd Book animals.

${ }^{7} \mathrm{C}$. H. Williams, according to the Herd Book of 1857, was owner of 9 registered shorthorns. In 1858, at the state fair held at Madison, his Kentucky bred bull "Paris," No. 1995 (see cut) took first premium in the shortlorn class. 


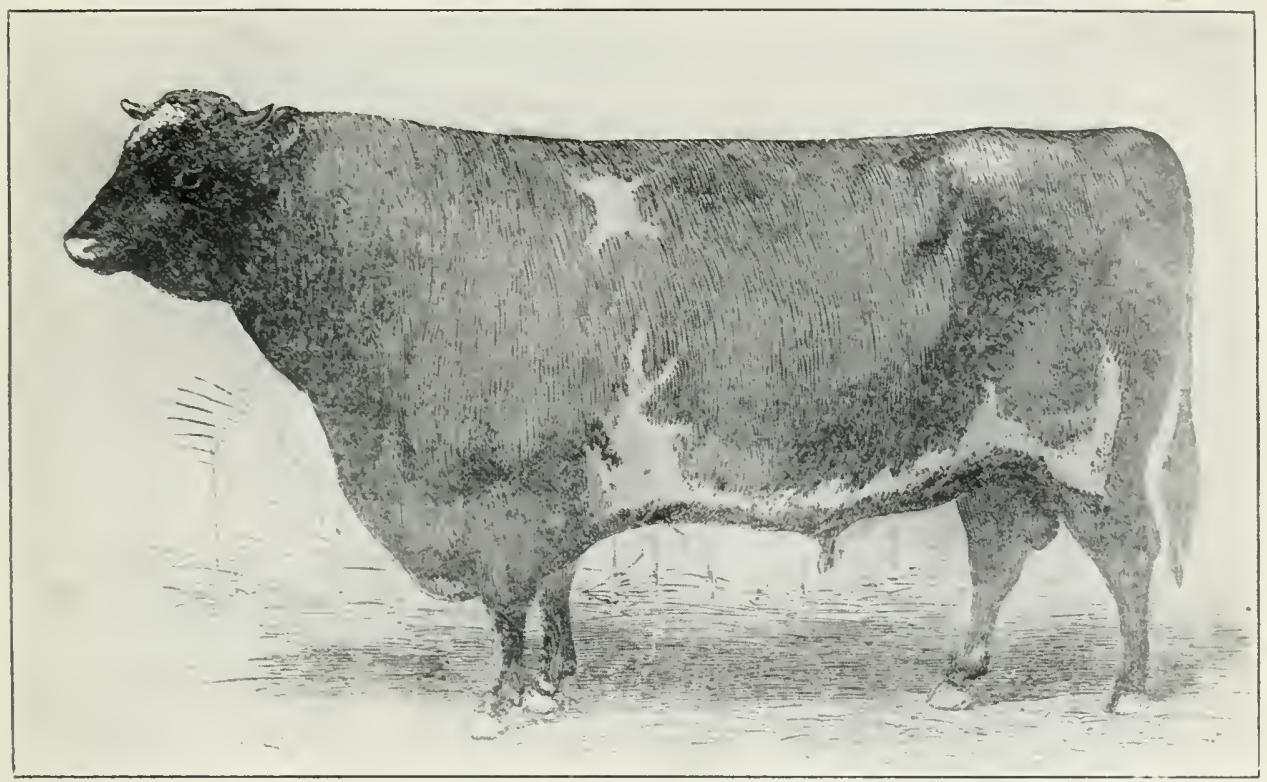

PARIS-DIRHAI, OWNED BY C. II. WILLIATS, EXCELSIOR, SAIK COUNTY

First prize at state fair, 1558

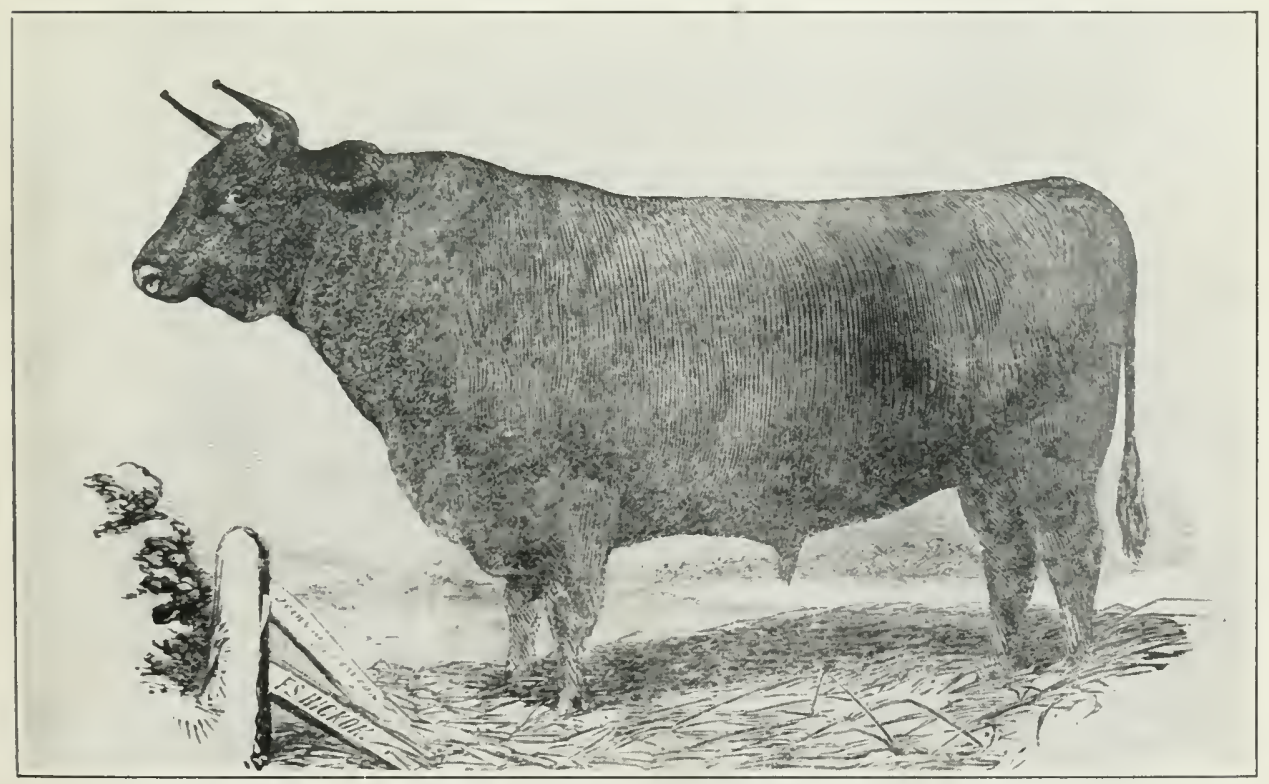

BLOOMFIELD 3H-DEVON, OWXED LY THOAIS REYNOLDS, MADISON

First prize at state fair, 1955 


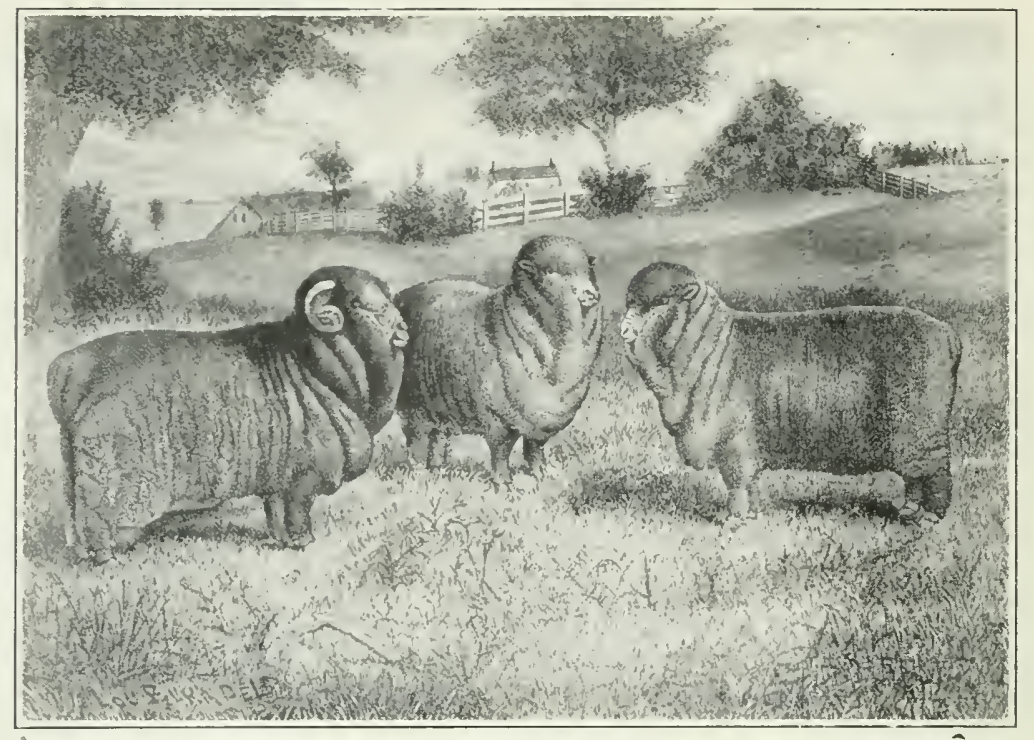

PRIZE WINATING SPANISH MERINOS

Bred and owned by Charles MI. Clark, Whitewater, about $157 \mathrm{~s}$

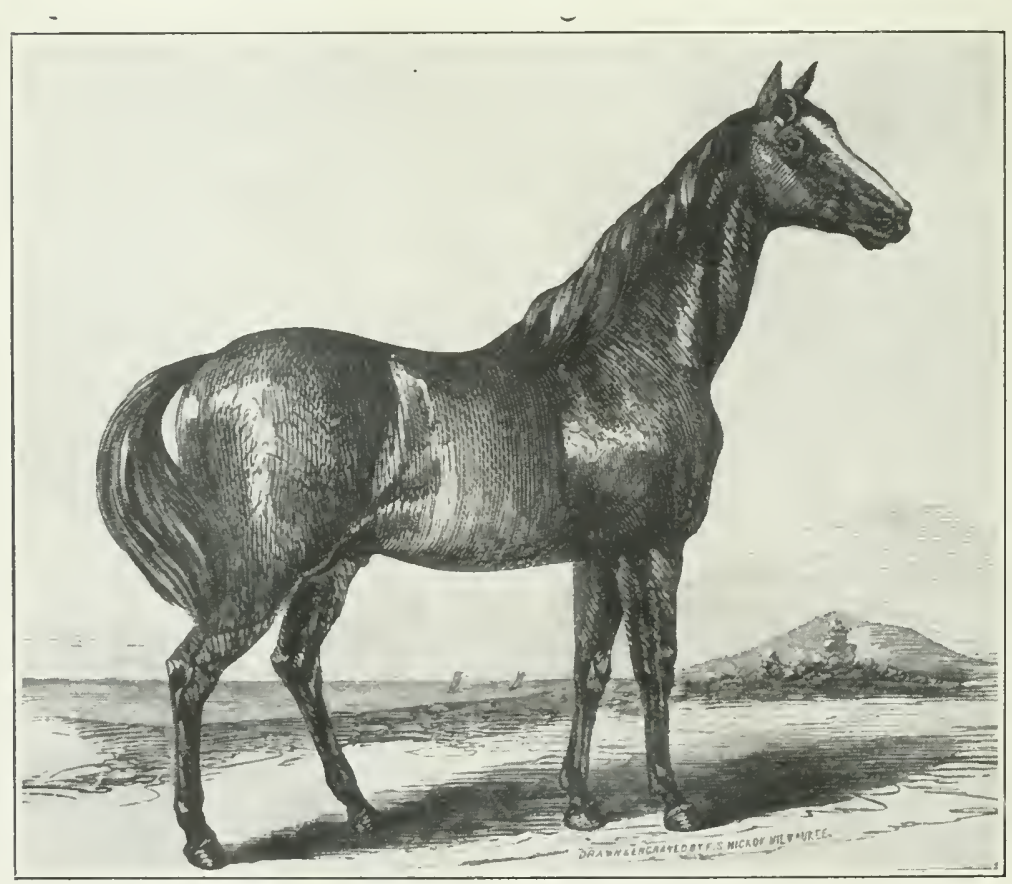

BLOOI) HORSE-- KING OF CYMRY

From State Agrieultural Society Transactions, 1854-57 
ica. In April, 1873, Mr. Murray held a public auction at his farm in Mount Pleasant, when visiting buyers were said to have numbered above 400 from both the United States and Canada. At that sale 21 cows and heifers brought the sum of $\$ 18,640$, or an average of $\$ 887$; while 9 bulls were sold for $\$ 5565$, or an average of $\$ 619$. This was one of the most successful sales held in America in that period. ${ }^{8}$ Mr. Murray bought choice animals in Canada, in Kentucky, and indeed wherever he could find individuals of the types and the breeding calculated to improve his herd. Throughout the decade of the seventies his stables and pastures just outside the city limits of Racine were a mecca for shorthorn breeders and fanciers, though his stock was rather too high priced to be available to the ordinary farmer.

Most of the prize winning horses exhibited at the Wisconsin state fair up to the Civil War were Morgans and Blackhawks. The latter were simply one strain derived by a process of careful breeding (with "blood-horse" stock) from the original "Justin Morgan," progenitor of the Morgan line. There were a few entries of blood horses, as the English thoroughbreds were called in the Transactions, but only a few. R. M. Wheeler's "Hambletonian," referred to above, was brought from Vermont in 1850. He traced back through the English "Eclipse" to Darley's "Arabian," 1700. On the side of the dam, however, his breeding was in doubt. Another blood horse, "King of Cymry," was imported into Wisconsin in 1854 by Captain McKinnon of the British navy and kept at Menasha. In his veins was some of the best blood represented on the English turf, and the claim was made, perhaps with justice, that he was the "first English thoroughbred horse ever imported into the state." The problem of pedigrees in the case of horses entered as blood horses was so serious that as late as 1858 the committee of judges ruled out the only two

See Racine Journal, Apr. 16, 1873. Cinarles M. Clark of Whitewater, who was a rival shorthorn breeder, told the mriter that at a later time he saw Murray sell at a Chicago sale his famous old cow "Duchess of Thorndale" with two of her heifers and one bull for more than $\$ 20,000$ ! The heifers each brought $\$ 8000$.

- Statement of George O. Tiffany, Wis. State Agric. Soc., Trans., 1854-57, 512. 
exhibits in that class because their pedigrees were unsatisfactory.

On the other hand, as early as 1852 T. J. Wood of Baraboo exhibited "Vermont Morgan," represented to have been of pure Morgan breeding in the Gifford Morgan and Sherman Morgan lines. Another Morgan sire, "General Gifford," was brought from Vermont about 1854 by John M. Clark of Whitewater. That horse was winner of the first prize at the state fair in 1857, where he competed with two Morgan stallions and seven Blackhawks. In 1858 there were again exhibited two Morgan stallions, one owned in Fond du Lac County, the other in Milwaukee. Both were approved as to pedigree. That year there was a notable showing of Blackhawks, "some of them splendid specimens of that stock-probably equal to any that have ever been produced." 10 Among the prize winners were stallions from Waukesha, Dodge, Racine, and Milwaukee counties.

The Morgan (and allied Blackhawk) blood became so widely diffused through southern Wisconsin that, during the Civil War, the cavalry regiments from this state employed as mounts to some extent the medium sized, but strong, spirited, wiry, and fleet footed chargers descended from that famous Green Mountain stock. ${ }^{11}$

In the years following the war occurred a remarkable development in horse breeding for the turf and for pleasure driving. The American thoroughbred, especially the horse of Kentucky breeding, was the favorite for these purposes. Interest was keen in every portion of the state, stimulated no doubt by the fairs and driving associations ${ }^{12}$ in the actual business of producing fine horses, however, Racine County was easily the leader. Men from that county visited the cele-

${ }^{10}$ Report of the Committee on Blood Horses, official. By Andrew Proudfit, chairman. Wis. Farmer, 1856, 546-549. An admirable, informative report.

" Ex-Governor Hoard told of his escape from rebel troopers through the fleetness and endurance of his Morgan mount.

12 The first law authorizing the "incorporation of associations for improving the breed of horses" was published April 1, 1859. 
brated studs of Kentucky and brought back promising colts. ${ }^{13}$ Richard Richards, Murray and Kelley, J. I. Case, A. P. Dickey, Stephen Bull, William L. Utley, Gilbert Adams, and others entered the lists as breeders of thoroughbreds, and soon it was said, probably with truth, that Racine County had more standard bred horses than all the rest of the state taken together.

The Racine breeders sold many animals for shipment into the western states. Customers came from Minnesota, Dakota, Nebraska, and Kansas, Iowa, Colorado, Wyoming, and Montana, occasionally from the Pacific states also. For example, in $1871 \mathrm{~A}$. P. Dickey shipped 17 head of horses to Denver, Colorado, among them the stallion "Red Cloud," which was sold for \$3000. ${ }^{14}$ Richards owned "Bellfounder"' as early as 1866. He secured the more noted sire "Swigert" (see portrait, p. 125) apparently in 1869 from the Alexander farm in Kentucky. ${ }^{15}$ Within a few years he was shipping colts to most of the states named. ${ }^{16}$ After awhile J. I. Case, the manufacturer, who was a great horse fancier, had perhaps the largest, most valuable stud in the state. There were, however, as might be expected, prominent breeders in other counties. For example, Mr. Richard Pheil of Milwaukee developed about 1865 a fine stud which included "Escape," "Bill Tenney," "Crichton," and "Riga," also a number of thoroughbred mares. Other Milwaukee men owned excellent individual horses, as did men in other cities, so that by 1880 or thereabouts it had become comparatively easy for farmers in almost every part of southern Wisconsin to gain access to thoroughbreds for breeding purposes.

It must be said, however, that no very general movement to build up the equine stock of Wisconsin farms by crossing

\footnotetext{
see Racine Journal, July 26, 1871, for an account of Dr. Champlin (veterinary surgeon) paying a visit to the Alexander farm and returning with "three blooded colts."

14 Racine Journal, Feb. 28, 1871.

${ }^{25}$ Western Farmer, 1869, 116.

${ }^{20}$ As shown by his account book (MS.), in possession of Mrs. Laura Richards, Madison, Wis.
} 
common animals with thoroughbreds ever took place, frequent as such crosses were in given localities. ${ }^{17}$ The common horses of Wisconsin, derived from various sources-Canada, Pennsylvania, New York, and the prairies of the West-were prevailingly of very moderate size and weight. A farm team weighing 1200 pounds apiece was the exception rather than the rule. They ranged from 900 to 1300 , the average probably being around 1100. It was because of the light weight of the horses that oxen continued to be used for the heavy, slow work of clearing and breaking. And even with the lands mostly under cultivation, farmers recognized the desirability of having horses of greater weight and strength than the common stock for the regular farm work. Since heavy horses also found a readier market, at good prices, than any other type save extra fine matched carriage teams, an added impulse was given to breeding for size and weight, for which purpose the thoroughbreds were not particularly beneficial.

When breeders began seriously to study the farmer demand, they met it by importing purebred animals of the heavy draft breeds, especially Normans or Percherons, and Clydesdales, afterwards adding also Belgians and English shires. The response was immediate. Activity in importing and breeding draft horses grew apace, and it spread over the state much more generally and more quickly than did the breeding of thoroughbreds. The counties of Rock, Columbia, Sauk, Dane, Dodge, Waukesha, and Milwaukee, aside from the sontheastern counties, competed for recognition at the fairs. In 1880, for the first time, the State Agricultural Society offered prizes for draft horses under two classifications: (1) Norman; (2) Clydesdale and others. The winning Normans came from Janesville, Dayton, Stoughton, Okee, Ableman, and Mazomanie; the winning Clydesdales (and others) from Madison and Brooklyn in Dane County, and from Illinois.

To show that Racine was not inadaptable, we find George Murray and Richard Richards, erstwhile breeders of thor-

${ }^{27}$ Like Racine County, where farm auction offerings of livestock were apt to specify colts sired by some great trotter like Swigert. 
oughbreds, carrying away prizes on their Clydesdales, the former in 1875 taking not only general prizes but also the "breeder's special premium" for the best draft stallion of any breed and the second best mare of any breed, also sweepstakes on horses for best stallion and five of his colts, and best mare with foal by her side. A son of Richard Richards, Griffith Richards, residing at Cambria, Columbia County, also captured prizes with his Clydesdales.

Within twenty years after 1880 the farm stock of horses had become profoundly and almost universally modified as a result of the multiplication of draft breed sires and their general distribution over the state. Nearly every farm had its "big team" or teams for the heavy farm work and for heavy hauling. Horses weighing 1400 pounds became as common as those of 1200 had been earlier. Driving horses, which continued to be useful for a time and somewhat divided the interest with draft horses, have declined in importance since the coming of the automobile.

A question has arisen whether addition of weight has not actually gone so far as to be uneconomical, particularly since the advent of the tractor, which affords relief from the heaviest farm draying. For some years a movement has been in progress looking toward a different type in the breeding of farm horses. It is now maintained, by some experts, that crosses between the large farm mares, compounded mainly of draft horse blood and the common stock, and purebred Morgan sires will produce the ideal farm horse. Many such are already to be found-fine, well knit, clean limbed, warm blooded animals weighing 1200 to 1400 pounds, fit for the plow, the dray, the self-binder, and all other farm work, and not ill adapted to the saddle or the road harness. ${ }^{18}$

While breeders very properly place the emphasis on purebred animals as the surest means of improving the quality of cattle, horses, and other livestock, it should be noted that very

${ }^{18}$ It may well be that, the problem of size being solved through the persistent use of draft sires, "blood horses" hereafter may be much more sought after than formerly for farm breeding purposes. 
real improvement resulted also from the use of grades and crossbreeds. For a good many years the average Wisconsin farmer was loath to incur the expense involved in the use of high priced breeding animals. A purebred shorthorn calf might cost from $\$ 50$ to $\$ 200$; a grade calf would cost, say, $\$ 10$. The temptation, accordingly, was overpowering to take the cheaper. This made farm breeding an uncertain process, with benefits far below those attending the general use of purebred males; but the net result was a decided improvement over the old-time "scrub" stock. Historically, it was very largely, even mainly, by the employment of such grades that the first general improvement of farm cattle came about, and the same statement will cover the case of farm horses, though when we come to the smaller and less expensive farm animals-pigs and sheep-we find a more general tendency to employ purebreds. ${ }^{19}$

Wool production in Wisconsin up to about 1870 followed closely the course of that business in the country as a whole. Wool growing for household industrial uses had been common from early colonial times, but wool growing as a commercial enterprise developed in the United States between the years 1808 and 1830.20 The influence bringing about the change was the development, partly through war and embargo, partly through the protection of infant manufactures, of the woolen industry as carried on by the factory system. Coincident with the beginning of the American factory production of woolens came the importations of merinos from Spain, begun by Consul William Jarvis, which totaled in about thirty months nearly 20,000 head. For a few years, under the stimulus of high prices for fine grades of wool, the country went mad over

\footnotetext{
2. Anyone who was familiar with the farm stock of horses of forty or fifty years ago can recall individuals that were specially agreeable to ride or drive, others that were famous emergency "pullers," still others that could earry the plow at a good clip twelve hours per day. By tracing their descent through sires advertised as "'half-Canadian," "part Blackhawk," or "three-quarter blood Morgan," such characteristics are often explainable.

${ }^{3}$ See L. G. Connor, "A Brief History of the Sheep Industry in the United States," Amer. Hist. Assoc., Annual Report, 1918. This is an invaluable survey of the field and is my chief reliance for the general facts referred to under this topic.
} 
merinos. Fabulous prices were paid for breeding stock. Flocks of purebreds became especially numerous in Vermont, the home state of Mr. Jarvis, but many were started in other states also. ${ }^{21}$ Then a period of manufacturing depression, due in part to English competition in woolens, forced down the value of sheep and resulted in sending many thousands of common and grade merino animals into the West, the states of Ohio, Kentucky, Indiana, and Illinois gaining largely therefrom. This created the sources from which the supply of common sheep in the forties and fifties reached Wisconsin.

In 1837, when Wisconsin began to settle up from the East, there were in the United States, it is estimated, 18,000,000 sheep, of which the three states New York, Vermont, and Pennsylvania had one-half. The factory demand having risen steadily for some years, the finest wool was then bringing up to 72 cents per pound and wool growing, naturally, was regarded as a most profitable branch of farming. This continued to be the case for about ten years and explains why it was that Wisconsin farmers, the moment wheat crops began to deteriorate, turned their attention to wool growing. It explains why for some years the interest in good sheep was so much keener and more general than the interest in better cattle, horses, or pigs.

Means of transportation from many parts of the West being almost non-existent, the market for wool in those sections was correspondingly poor and the prices of sheep low. That is why so many flocks, numbering thousands, were driven north from Illinois and Indiana to be sold to Wisconsin farmers at prices which made their purchase a strong temptation, especially since wool could be shipped cheaply from the lake ports via the Erie Canal to the eastern market. Under these conditions, wool growing began in Wisconsin a few years after the first settlements were made. It is said in 1845 there

Not infrequently as much as $\$ 1000$ was paid for a ram. The furore became so great that, it is said, a good mother in Pennsylvania called her tenth son "Merino," as fathers in 1856 named male children "Fremont" and in 1860 "Lincoln." 
were not over 30,000 head of sheep in the territory, yet in 1850 the census taker found 125,000 head. ${ }^{22}$

We have already noted the prominence given to sheep at the first state fair in 1851. The merinos, paular merinos, and Saxons, exhibited from Kenosha County and from Fond du Lac, were a pledge of the effort at improvement of the stock of sheep which had already begun, purebreds being brought from Vermont, Massachusetts, and New York. It was only a few years until Wisconsin breeders were prepared to supply breeding stock of both sexes and all ages to their fellow farmers. The records of state fairs prior to 1860 testify to the existence of purebred merinos in Kenosha, Waukesha, Fond du Lac, Walworth, Milwaukee, and Dodge counties. Doubtless there were flocks in other counties as well. Long wools were exhibited mainly from Dane County.

The county of Walworth became the leading county in the production of fine wool sheep, and in that county the town of Whitewater was the most noticeable competitor at the state fairs, her breeders usually numbering four or five. ${ }^{23}$ In 1850 Whitewater had 3282 sheep, more than those in any other of 10 towns. In 1860 the number was 2734 , which again was the largest number assigned by the census to any one of 22 towns. In 1870 the number had risen to 6030. Whitewater's nearest competitor that year was Sugar Creek, in the same county, where the number of sheep was 5449, while in Mount Pleasant, Racine County, it was 5432.

From the census returns of wool and of sheep one can compute, roughly, the average yield per head, and this enables us to determine where the improved sheep were to be found at the census dates. In 1870 Whitewater sheep clipped, on the average, nearly 6 pounds, and Mount Pleasant sheep about the same. In Brookfield, Waukesha County, the average was 4.7, in Bangor less than 3, in Castle Rock 2 pounds. Empire

\footnotetext{
22 The importations hecame even more numerous in the next decade. In 1854 it was said (see Wis. Farmer, 1854, 227) of sheep: "They have been brought into this state this season by thousands."

${ }^{20}$ Included as from Whitewater, however, were men living in the adjacent town of Lima, which is in Rock County.
} 


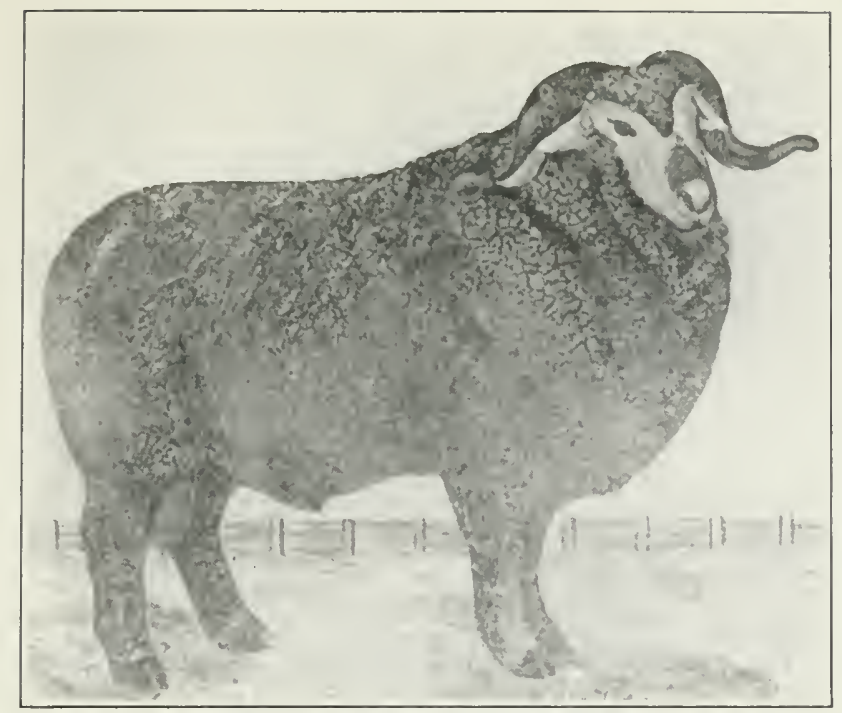

YOTNG FREAIONT-FRENCH TIERIXO

Brerl and owned hy Giles Kinney, Whitewater. First shoru at two years of age. Weight of fleece, well washed, it pounds. From State Agricultural Society Transuctions, 18.59

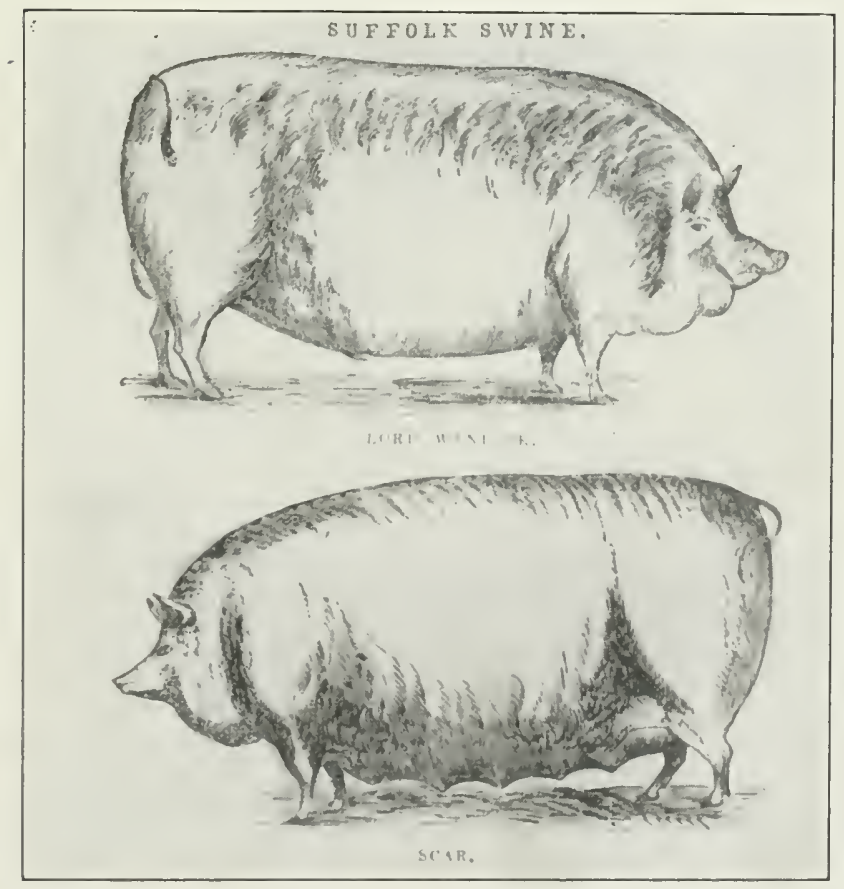

PRIZE WINXING NEW YORK SUFFOLK PIGS From Wisconsin Furmer, 1.5:5 


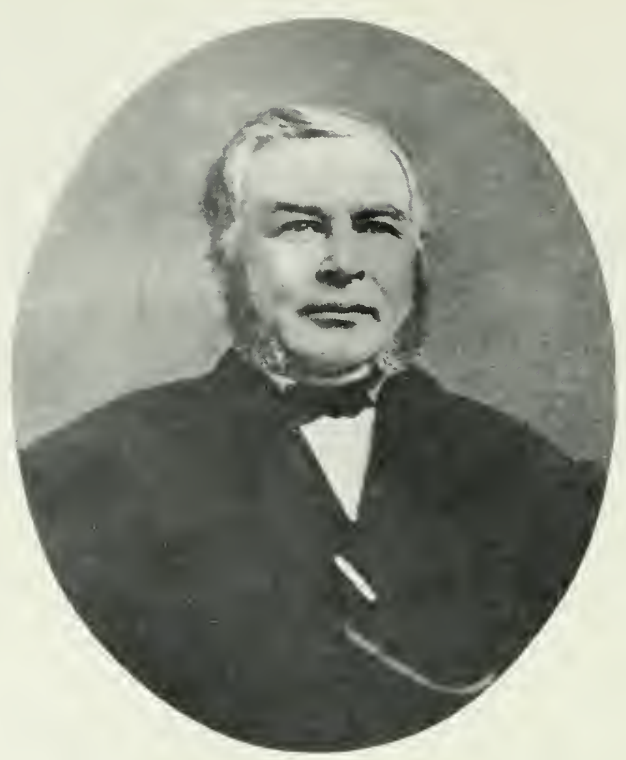

RICHARD RIF'IIARDS

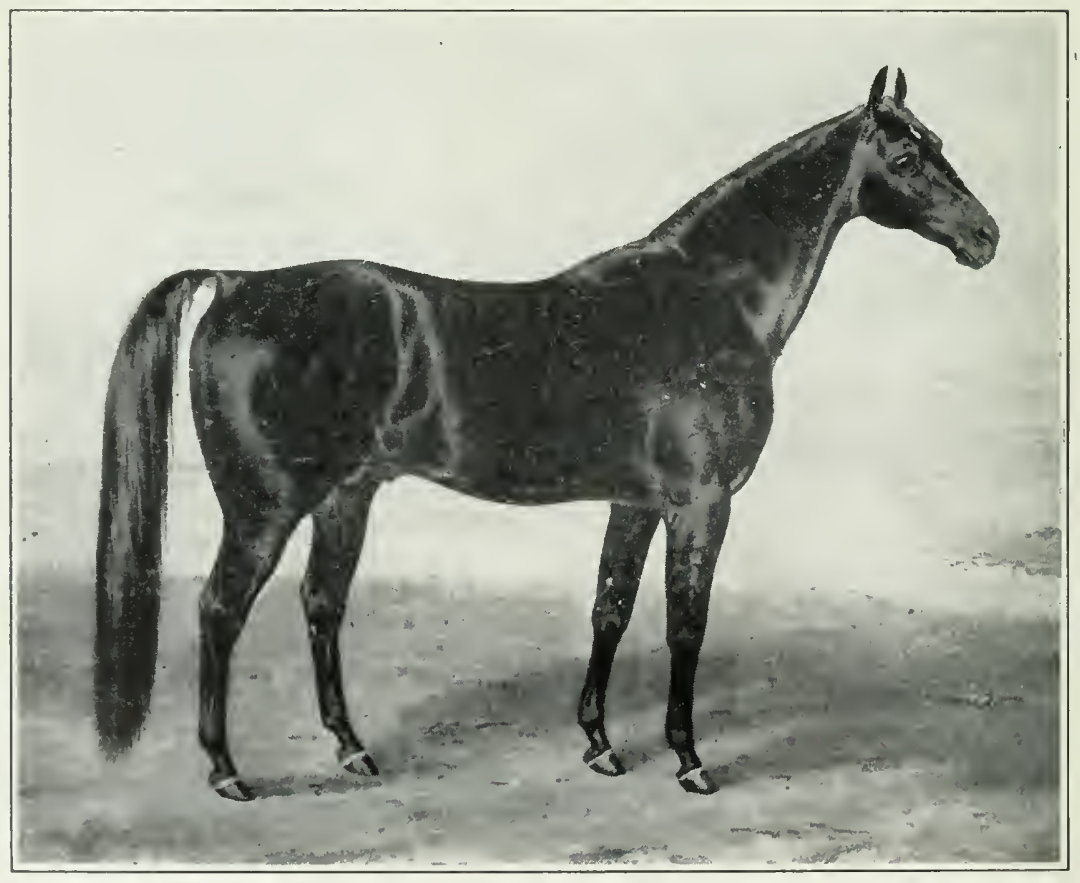

THOROLGIIBRED HORSE-SWIGERT

After an oil painting in possession of Mrs. Laura Richards, Madison 
in Fond du Lac County sheared nearly 5, Franklin less than 2, New Glarus nearly 4, Newton 3+, Norway 2.3, ${ }^{24}$ Orion 3, Pleasant Springs 3.2, Plymouth 4.7, Prairie du Chien 2+, Primrose 3+, Pulaski 3+, Sparta 4t. This comparison places in one category towns representing Walworth, Racine, Waukesha, Fond du Lac, Green, Rock, and Monroe counties, and suggests that the improvement of sheep, doubtless through the use of purebred merinos, had become very general in those communities. We know from other sources that this was true. Such general improvement had likewise taken place in some counties for which we have no representative towns in our list, for example Kenosha. A writer in the Racine Argus, November 30, 1867, says: "Within a circle of about ten miles around Rochester, embracing a part of Racine, $\mathrm{Ke}$ nosha, Walworth, and Waukesha counties, is to be found, we think, the most extensive wool-growing section of the state of Wisconsin. The quality is very superior . . . and this year, in the eastern markets, our wool ranks fully equal to that of Michigan and brings a price accordingly." ${ }_{25} \mathrm{He}$ adds that one of the dry goods merchants at Rochester had purchased that summer 185,000 pounds of wool.

It is seen that the suggested circle excludes Whitewater, and it is true that that town was not especially well adapted to sheep, most of the land save in the northwest and the southeast being too low. Her leadership was due to the breeders, not the general farmers, and the high average of the clip both in Whitewater and in Mount Pleasant was due to the high per cent of purebred merinos in the count. Unimproved sheep, such as were driven up from the south in the early days, would shear about 2 pounds of wool apicce. A good fiock of merinos often sheared 6 or 7 pounds. Individuals vielded much more than that.

24 Norway cornered with Mount Pleasant, yet the difference between the two towns in this respect argues that the people of Norway had benefited little from the improvement of sheep which was going on in their vicinity.

${ }^{25}$ Compare map showing distribution of sheep in Wisconsin. Connor, op. cit., appendix. 
Wool growing encountered difficulties from price fluctuations at various times before 1870 . But by that date the price was dropping so steadily as to discourage Wisconsin wool growers, especially those engaged in raising fine wool. The consequences were two: First, many flocks were sold for shipment to the great western sheep ranges, where wool could be grown more cheaply; second, the mutton breeds, long and medium wooled, were substituted for the fine wools. When the new dairying came into full vigor during the seventies and the eighties, many farmers dropped the earlier interest in both wool and mutton, devoting themselves to the more dependable business of producing cheese and butter.

Since 1870 sheep raising has been mostly on the decline in Wisconsin, but under the principles of diversified agriculture now advocated, it is held to be economical for every farmer to keep some sheep as a subsidiary line in connection with dairying, beef raising, or pork raising. Sheep, it is argued, will pasture the rougher lands, make best use of the coarser forage, and thus save what otherwise would be waste. A certain small per cent of Wisconsin farmers have already gone back to sheep on this new basis. The breeds used are long and middle wools.

Hogs are animals we have had always with us, but they have not always been the shapely, sleek, contented, and well behaved creatures now to be seen on every farm. The original "prairie racer," product of devolution rather than evolution, was by no means a thing of beauty or an unqualified joy. He was tall, lean, bristly, with a neck nearly as long as his body and a fearsome tusky snout resembling that of the wild boar celebrated in the traditions of the chase. That this beast was troublesome is attested by the efforts of the pioneers to construct a satisfactory "hog-tight" fence. And even when they had it, in the nine- or ten-rail "worm fence," these hogs, so tradition says (doubtless with some exaggeration), would put their heads through between the second and third rails and root up three rows of potatoes! They matured very late, were unconscionable food wasters, and their flesh at best was 
only tolerable. ${ }^{26}$ So they required to be improved, and improvement had a long way to go to reach the ideal.

As already stated, hogs of the above description were brought up in droves from southern Indiana and southern Illinois to be sold to Wisconsin settlers. Practically all of the original stock of the territorial period was obtained in that way, and the droves continued to come for a number of years after statehood, though then they sought out the newer settlements. They were woods-grown swine which had been permitted to multiply, at random, with no particular care on the part of their owners and, naturally, no attention to breeding for improvement. Crossed with the improved breeds, like the Suffolk, Cheshire, or Berkshire, and kept under favorable farm conditions with good and abundant feed from birth to maturity, the stock was susceptible of rapid betterment. Most of the farmers of southeastern Wisconsin, being accustomed to keeping hogs in pens and paddocks, and feeding them regularly, also having familiarity with the breeds which were considered the easiest keepers and best fatteners, were not content to continue long with prairie hogs. A very few years were sufficient to change these into a type unrecognizable by the Hoosier drover, or to supplant them entirely with new stock derived from Ohio, Pennsylvania, New York, or some other part of the East. The rapidity with which pigs multiply made the process of improvement both easy and quick. A pair of good pigs was sometimes the means of transforming, in the space of five or six years, the pork raising interests of an entire county. The Wisconsin climate was too rigorous to favor the southern Indiana mode of hog raising, and besides, prairie settlers lacked the temptation of forests to serve for hog commons. All this tended to limit the number of hogs raised and also to encourage care and attention in both feeding and breeding.

Of the standard English breeds of swine the Suffolk attained earliest popularity at the state fair. In 1853 S. B. Edwards

\footnotetext{
${ }^{20}$ Many stories have been told to illustrate the fierceness of these half-wild hogs.
} 
of Troy, Walworth County, who is said to have done more to advance the pork industry than any other early breeder, exhibited at the state fair a pair of imported Suffolk pigs six months old, and also a pair of imported Essex pigs. He made the Suffolks his specialty. However, there was but little interest in better swine, as shown by the small number of fair exhibits. In 1854 the entries numbered only 4, in 1855 none. In 1856 there were 22, mostly Suffolk and Essex. In 1857 the committee on award reported "that their duties were not very arduous, as the number of swine present was very small, quite too limited even for a county fair, but the quality generally was very good." The prizes went to Rock, Walworth, and Waukesha counties, and the Suffolk breed was the only one mentioned by name. That breed continued to be the favorite apparently until the close of the Civil War, although Yorkshires, Chester whites, Sheffields, and Essexes appeared among the exhibits from time to time.

In 1870, for the first time, the Agricultural Society's report featured swine strongly in the account of exhibits at the state fair. Swine were grouped under three classes: (1) small breeds (Suffolks, Chinas, Essexes, etc.); (2) large breeds (Berkshires, Chester whites, etc.) ; (3) animals not on list of prizes offered. The winner of the largest number of prizes was Richard Richards of Racine, who had exhibits in both the small breed and the large breed classes. Richards concentrated, however, on the Berkshires, and the next year, 1871, he was shipping Berkshire pigs to distant California, where they arrived "safe, salubrious, and satisfactory.",27

The date 1870 may be taken as fixing, roughly, the establishment of a new interest in swine breeding. Prior to that time comparatively few farmers raised pork as a regular business. But, wheat growing having become demonstrably unprofitable, and the old-time glamour having passed also from wool growing, resort was had to the hog because corn

\footnotetext{
"Letter of Roger S. Day, consignee, dated Folsom, California, May 10, 1871. In Racine Journal, May 24, 1871.
} 
could be grown successfully to any extent and marketed profitably in the form of pork, the cost of breeding stock was but a trifle, and the increase rapid and certain. Hogs, indeed, saved the careers of thousands of Wisconsin farmers brought to the verge of bankruptcy by unwise persistence in wheat raising; so that the arresting term "mortgage-lifters" is not illapplied to the porcine branch of farm livestock. The economy with which pork raising can be carried on in combination with dairying has enabled the business to survive all recent readjustments and to become in fact a permanent feature of Wisconsin agriculture. Purebreds of the several favorite breeds, such as Jersey reds, Poland Chinas, and Berkshires, are legion in all corn growing sections of the state. 


\section{CHAPTER VIII}

\section{LUMBERING AND FARMING}

A New England land seeker wrote in 1847 from Fort Winnebago to his wife in the East, saying: "Where I now am seems upon the confines of civilization. About a mile to the north of this place commences the Indian territory which extends to Lake Superior. . . . I intend to take a quarter-section of land on the Baraboo. . . . It is said to be a fine farming country with fine springs and streams of water. . . Pine lumber can be bought there from 8 to 10 dollars per thousand and produce brings a higher price on account of its being near the pinery."

Baraboo is in Sauk County, and the settlers there, as well as those in Columbia, Dodge, Fond du Lac, Winnebago, and Brown counties, were, by the time Wisconsin became a state, beginning to see marketing possibilities in the sawmills and lumber camps which were multiplying along the upper Wisconsin and its tributaries, near Green Bay, and in the Wolf River pinery. Woods work being carried on most actively in winter, when frost, ice, and snow prepared roads into regions otherwise impenetrable, supplies could be transported on sleighs to almost every portion of the lumbering area. Flour, pork, beef, and potatoes among farm products, also hay and corn or oats for the stock, were in sharp demand and brought good prices at the mills. Large numbers of oxen were required for draught in the woods. Men owning strong, well broken cattle could obtain winter employment at good wages, while vigorous young ax-men, raftsmen, and mill hands were always in demand during the season when work on the pioneer farms was at a standstill. Thus the advantages of farming in the neighborhood of big

\footnotetext{
${ }^{1}$ Letter of A. G. Tuttle, dated Feb. 15, 1847. Printed in Baraboo Weekly News, May 4, 1922.
} 
and fairly permanent lumbering establishments were not few nor inconsiderable. Taken altogether they made so strong an attraction that, wherever good land could be obtained in proper locations, it was sure to be taken up as soon as possible after the mills began operations.

The lands of northern Wisconsin vary in character quite as much as those in the south. Wherever the pine forest covered the country continuously and fully, the problem of clearing made farming impracticable even after the timber was removed, because in the days when prairie lands were still cheap and abundant the expense of stumping could not have been borne. Many of those lands, which have been for some years cut over, are only now coming into cultivation, the process of removing stumps by blasting having demonstrated its economy.

However, there were millions of acres of good farm land, in regions which also contained pineries, that presented no more serious obstacle to cultivation than the oak openings of the south and southeast, and other millions which involved much less slashing, grubbing, and burning than did the forested area near the shore of Lake Michigan. In fact, oak openings occupy a large part of such counties as Waupaca, Outagamie, Adams, Waushara, and Marquette-the first region of northern Wisconsin east of the river into which agricultural settlers thrust themselves, following in the wake of the lumbering interest. The same was true of the limestone region in the north and west, settled almost as early in response to the lumbering activities on streams tributary to the upper Mississippi.

Much of the remaining land was covered with varieties of hardwoods similar to those in the Milwaukee area, while the pine, which was the basis of the great lumber industry, stood largely in clusters on the rougher lands within a short distance of the streams and rivers. The conditions, in short, favored that combination and interplay of the two industries of lumbering and farming which is so distinctive a feature of northern Wisconsin history. 
The lumbering opportunities of the upper Wisconsin were prospected very early. In 1828 timber was rafted down the river to build Fort Winnebago. Within a few years keen traders, like Daniel Whitney, were seeking Indian permits for mills; then the government stepped in, secured a cession of lands along the river, and in 1840 surveyed a six-mile strip as far up the river as the present Wausau. The market for pine lumber outside of Wisconsin was in Iowa, Illinois, Missouri, and still farther south along the Mississippi, and it was a rapidly growing market. Except in times of panic or severe depression, there was hardly a limit to the amount of lumber that might be sold from the fleets of rafts which moored at the Mississippi ports. Besides, sawmills were erected at various places down the river, like Dubuque and Davenport in Iowa, which depended for their supply of saw logs on the pineries of Wisconsin.

The pinery was tapped also from the upper Mississippi, particularly along the courses of the Chippewa, Red Cedar, Black River, and the St. Croix. In these areas and on the upper Wisconsin, as well as on Lake Michigan, along the shores of Green Bay, and in the Wolf River country, the development of lumbering kept pace in a certain sense with the growth of the agricultural settlements of the southeast and the south. As early as 1840, according to the census of that year, the value of the lumber produced in Wisconsin was $\$ 202,239$, while the bushels of wheat raised was 212,116 . In other words, the value of Wisconsin's lumber product, at that date, was greater than the value of her wheat. We have already seen how rapidly the prairies and openings of the south were converted into wheat fields and how the product increased with the area of cultivation. While the lumbering business proceeded with less regularity, there were times when the onslaughts upon the forests of the north were fierce and relentless, so that the value of the product ultimately came to be far in excess of the value of Wisconsin's wheat. Proceeding by decades, the census of 1850 assigned to the lumber 


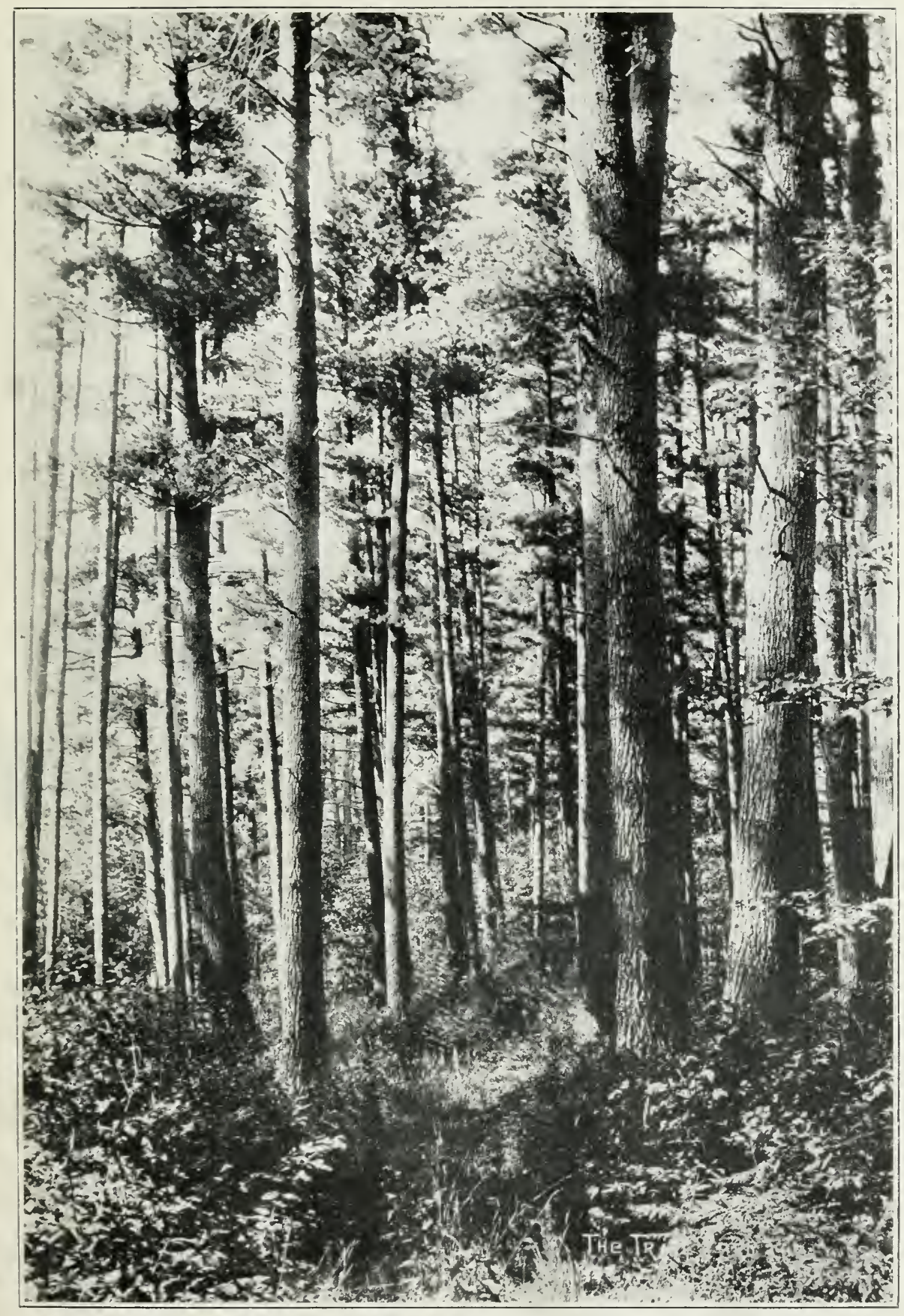




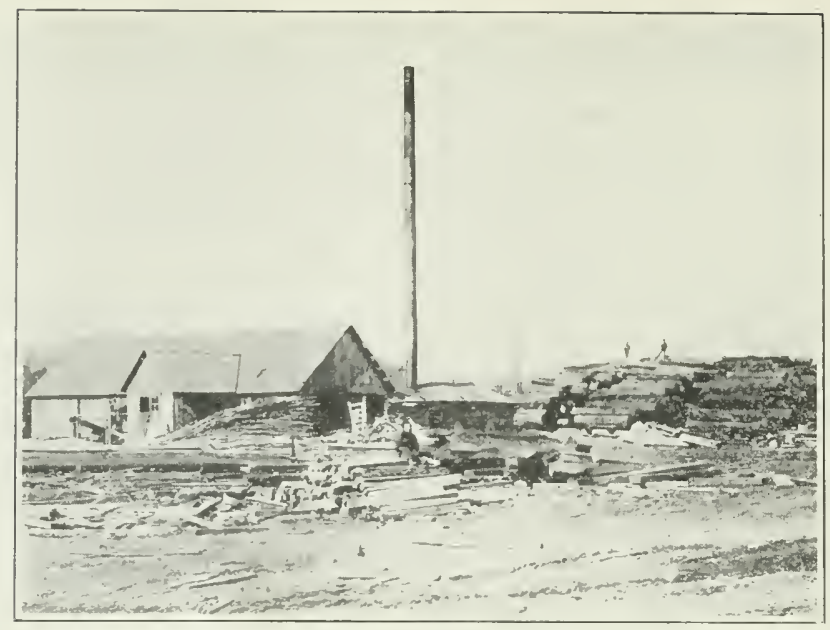

A NORTIEPN WISCONSIN SAWMILL

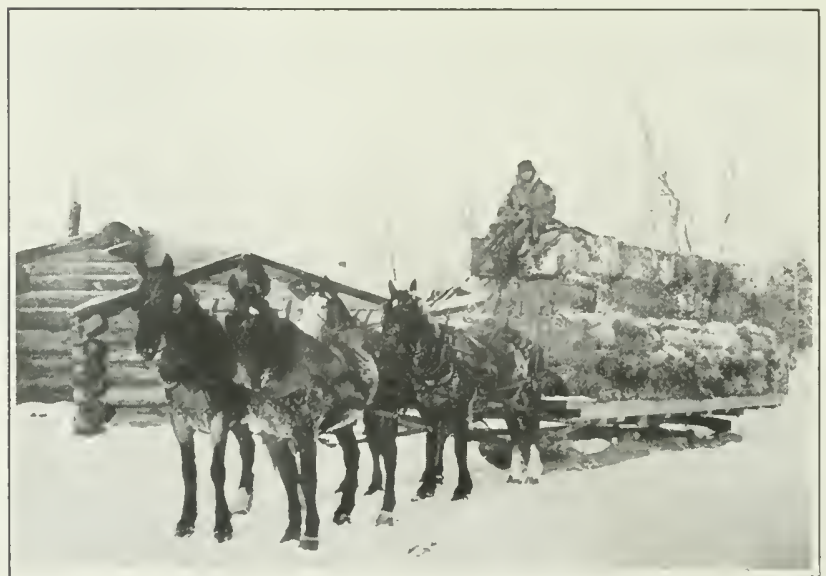

DELIVERING IIAY TO THE LUMBER CAMPS

From Henry's Northern Wisconsin 
output a value of $\$ 1,218,506$, while the next census showed $\$ 4,377,880$. That was far less than the value of the golden wheat crop of 1860 , but lumbering did not get under full headway until the years following the Civil War, when the transformation of the great plains from a huge buffalo range into a million farms, all rendered accessible through an unprecedented development of railways, created an unlimited market for pine lumber. In $1870 \mathrm{Wisconsin}$ made lumber to the value of $\$ 15,130,719$, which became $\$ 17,952,347$ in 1880 . Then we get the enormous leap to $\$ 60,966,444$ in 1890 , which is the culminating point in the lumber industry in this state. Thereafter it declined, as wheat raising had decreased a score of years earlier.

$\mathrm{By}$ the time lumbering began to wane in importance almost every portion of northern Wisconsin had been tested agriculturally, and the more accessible areas already supported a rural population of half a million or more. The grouping of the settlements was determined by a variety of factors. The first was proximity to the pineries, where were camps, mills, and mill towns that created an initial demand for agricultural produce at prices fully equal to what southern Wisconsin products brought in Chicago. This was the usual incentive for beginning the settlements. Secondly, the lumber output of the pineries induced the building of railway lines connecting the lumbering centers with one another and with the lake ports, and these railways in turn supplied the transportation facilities which enabled the farming interest to free itself from dependence upon the pineries' market, which was quickly glutted, and to expand as the environment presented opportunity. Opportunity, in any given region, was determined by the character of the land, its soil, timber, the water supply, and such other considerations as affected the choice of lands in the older districts.

The fairest opportunity for a large agricultural development in regions pioneered by the lumbermen came first in those counties near Fox River and Green Bay where the 
Fox River Canal, opened in 1851, guaranteed transportation for whatever produce could not be taken at the mills and camps. A line drawn from Green Bay due west to Stevens Point on the Wisconsin formed approximately the northern limit of that area, which occupied somewhat less territory than was contained in the Menominee cession of October 18, 1848. Because of difficulties over the removal of the Indians, the lands were not surveyed till the years 1851 to 1855 , but in advance of the surveys hundreds of squatters made claims within the newly created counties of Waushara, Waupaca, and Outagamie, as well as in Marquette County and the later Green Lake. With the progress of the survey a rush of settlement set in which quickly occupied most of the open lands, and gave to the five counties named an aggregate population by 1860 of 48,000 . In addition, the counties of Adams and Portage had a combined population of 17,250 , making a grand total for the region mainly included in the Menominee cession of $65,250,{ }^{2}$ or nearly one-twelfth of the state's population at that census.

Lumbering on the Chippewa and other streams entering the Mississippi has a history which is no less interesting than that of the Wisconsin and Wolf River areas. But, like the story just related, its significance in the present connection lies in the influence which it exerted upon the agricultural settlement of the then northwestern sections of the state. The Indian title to all that region had been extinguished by treaty as early as 1837, though many Indians remained for a number of years to hunt through its great forests. United States surveyors began their work north and west of the Wisconsin in the year 1840. East of that river and north of the Fox, negotiations with the Indian claimants delayed operations some years longer, as stated above, but by 1856 the survey extended, solidly, to the new base line which had been established at the distance of six miles north of the forty-fifth par-

\footnotetext{
2 The county of Portage (see map, p. 138) is included in the New North. Yet, its early settlement was essentially a part of the general movement into the Menomonee cession.
} 
allel. Along St. Croix River on the western boundary of the state several townships had been laid off as high up as the junction with that stream of Clam River, and along the $\mathrm{Me}$ nominee on the eastern state boundary township lines were established to the Big Quinisee Falls. ${ }^{3}$ In the Mississippi drainage basin the survey included the whole of Black River valley, the Trempealeau and the Buffalo, also the lower courses of the Chippewa, the Red Cedar, and the St. Croix. ${ }^{4}$

On all those streams the lumber business had attained large proportions and was giving rise to cities, of which La Crosse, just below the junction of Black River with the Mississippi, was the chief. ${ }^{5}$ Meantime, lands located in the flood plains of these and other rivers, prairies in the vicinity of the great pineries or of the center's of milling and rafting, oak openings and other lightly wooded lands equally well located and possessing good soil were being actively taken up by immigrant farmers. Transportation, as in the Menominee cession, was the determining factor in agricultural development as soon as the settlements produced a surplus above what the lumber business could absorb. To a certain extent, the Mississippi served as an outlet for grain as well as lumber, but the obstacles to its general use, already mentioned, ${ }^{6}$ made the building of railroads to the lake ports the chief guarantee of a permanent market for farm products. The building of the Milwaukee and Mississippi Railway provided an outlet to the lake for the whole area. The completion almost at the same time of the La Crosse Railway gave a powerful impulse to agriculture in the counties crossed by that line, as well as in those lying north of La Crosse on the Mississippi; for it was well

${ }^{3}$ See map of Wisconsin, by Silas Chapman, 1856.

- The Kickapoo, which enters the Wisconsin far down toward the mouth of that river but which taps a beautiful pinery in Monroe and Vernon counties, may well be associated with the Mississippi lumbering streams.

${ }^{5}$ The Milwaukee Board of Trade estimated the lumber product of 1860 at $800,000,000$ feet, distributed as follows: Green Bay and west shore of Lake Michigan, 375,000,000; Wolf River pineries, 100,000,000; Mississippi and tributaries (including Wisconsin River), 325,000,000. A good brief account of lumbering in Wisconsin is in Frederick Merk, Economic History.

"See p. 41. 
understood that extensions reaching as far northwest as St. Paul would not be long delayed.

The results were reflected in the census of 1860 , which assigned to the counties fronting on the Mississippi from Bad Ax (now Vernon) to St. Croix a combined population of 42,000 , to which should be added 20,000 from the 2 counties of Monroe and Juneau. The other counties in this region that had considerable populations were Dunn, Eau Claire, Chippewa, and Jackson, all served by navigable streams possessing apparently good transportation facilities. ${ }^{7}$

To sum up: That portion of the state which on our map we designate the Old North, consisting of 16 counties, showed in 1860 an aggregate population of 122,327 , or a trifle less than one-sixth of the total for the whole state. On the other hand, the vast, imperial domain, in area more than one-half of the state, which we call the New North, had at that time less than 31,000. Most of those latter, no doubt, were connected in one way or another with the lumbering business. That the old North was already mainly agricultural is revealed by the size of the population total, by the statistics of agricultural production, and by contemporary descriptions of various counties. The bumper wheat crop of 1860 , amounting to $27,000,000$ bushels, was appreciably indebted to the fresh fertility of the northern counties. The largest gross yield that year was from Dane County, 3,000,000 bushels, and the second best, $2,229,000$, was from Dodge. None of the northern counties could present records like these. Nevertheless, Green Lake produced 853,700, Marquette 171,000, Waupaca 170,000 , Waushara 180,000, Outagamie 146,600, and Adams 191,500. This made an aggregate for the 6 counties east of the river of $1,712,800$ bushels. In the western counties Juneau had 187,780, Monroe 196,000, La Crosse 297,670, Trempealeau 105,000, Buffalo 44,600, Pepin 44,000, Pierce 174,560, and St. Croix 148,280, making an aggregate of 1,197,890. Adding 1,049,400 for Door County, which with Kewaunee (possibly

T The last four counties might, with almost equal propriety, be included either in the Old North or in the New North. 
included in this total ${ }^{8}$ ) we credit to the Old North, the grand total for the region as a whole becomes nearly 4,000,000, or more than one-seventh of the state's crop.

Such a record marks a good beginning in agriculture. But, as already stated, ${ }^{9}$ these northern counties were destined quickly to attain a leading place among the wheat producing sections of the state. With St. Croix County standing first in per capita production of wheat in 1869 and again in 1879, Buffalo first in 1889 and 1899, all doubts as to the agricultural character of that portion of northern Wisconsin may be set at rest. Eight of the northern counties in 1869 have places in the list of the first 14 wheat counties on the basis of per capita production, and a similar result appears from the tables representing production per square mile of improved land and degree of specialization. ${ }^{10}$

In 1870 these 16 counties were credited with a population of 203,518. All but 4 had above 10,000 each, and 4 of those had 15,000 and over. While most of the counties of the older south were more populous, this area was nevertheless so fully settled, and so well developed agriculturally, that we can properly regard it from this time as an extension of southern Wisconsin. The region already participated in all movements for the improvement of agriculture, such as diversification, livestock improvement, and dairying. In the years following 1870 the people of those counties contributed heavily to the. new agriculture of the state and developed among themselves certain specialties, among which cranberry culture and potato farming were perhaps the chief.

Meantime, the 29 counties set off from the rest under the name of the New North (Fig. 16) still contrasted strongly with the new and enlarged south. With agriculture advancing in restricted areas, this was still mainly a region of forests, of which as yet only the pineries were interesting to the lumber-

\footnotetext{
- There are no separate figures for Kewaunee County. Wis. State Agric. Soc., Trans., 1860, table p. 52-53.

See p. 95.

${ }^{20}$ See tables in John G. Thompson, Wheat Raising in Wisconsin, Appendix.
} 


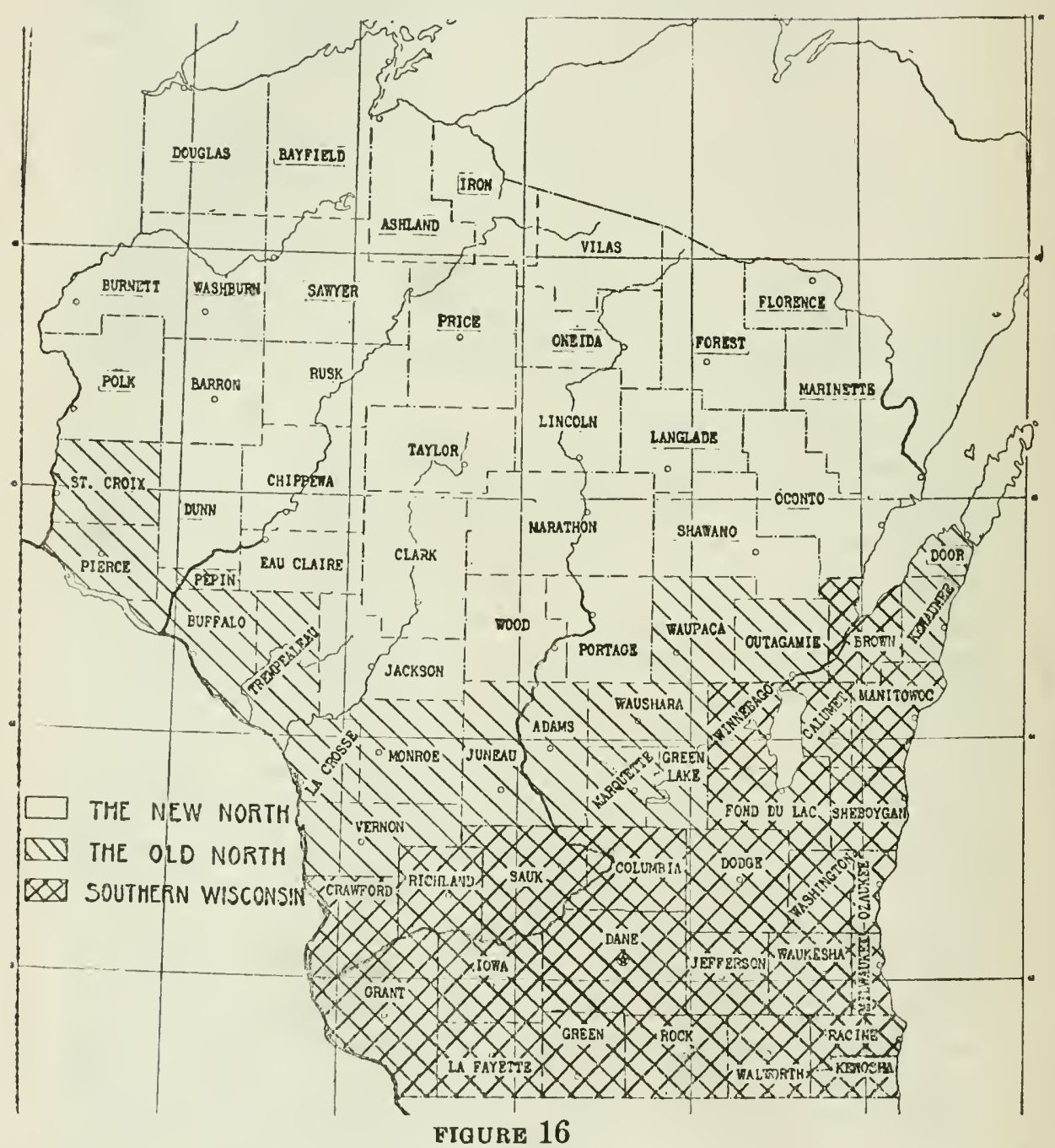


men. Enormous areas covered with finest hardwoods waited for their lumbering exploitation upon the exhaustion of the pine forests, and for their agricultural development upon the disappearance of the supply of fertile prairie lands in states farther west. Into these states Wisconsin was pouring her surplus population in generous measure, so that by 1890 nearly a quarter of a million natives of Wisconsin were found by the census takers living outside of her borders. Minnesota, for example, had absorbed 59,000, and Iowa 42,000. South Dakota, North Dakota, Nebraska, and Kansas had taken an aggregate of 78,000 , while the mountain states and the Pacific coast had made smaller drafts upon us.

At that date the aggregate population of the 29 northern counties was only 361,500 , and inasmuch as fully one-third of that number were foreign born it is doubtful if more than a third of the total consisted of natives of Wisconsin. This shows that the people had been spurning the lands of their own state lying in the wooded northern counties, while they contended eagerly with throngs of immigrants from every state in the union for a portion of those government lands which called for no grubbing, whether those lands lay 100,500 , or even 1000 miles farther from the general market. It was the age of prairie farming. The mind of the American farmer was set against the drudgery of land clearing, and he would not come back to it except under a kind of economic compulsion. The census of 1890 , which notes the passing of the frontier, established a convenient base from which to compute the pressure of that land shortage which gradually brought the vast and fertile areas of northern Wisconsin into requisition for general farming.

The lumbering business on a white pine basis has long since passed into the phase known as "cleaning up," which means that mills have been disappearing from section after section. To a considerable extent, lumbermen of Wisconsin secured holdings in the South and in the Pacific Northwest in anticipation of the exhaustion of the Wisconsin pine forests, and 
many have dismantled their works in this state only to reëstablish them elsewhere. Others have entered the hardwood fields or, with modified plant, have undertaken various lines of manufacturing in which timber and lumber are the standard raw materials. The business centers, some of them cities of considerable note, which were created during the lumbering régime have always struggled to maintain themselves when lumbering declined, and one way to do this was to promote lines of manufacturing based upon lumber.

Another method which was peculiarly available to most of the northern Wisconsin towns was to promote the settling up by farmers of the neighboring cut-over pine lands, the burned tracts, and the lands covered with hardwoods. In 1895 the state legislature passed an act creating a State Board of Immigration, with a secretary whose office was at Rhinelander in Oneida County. Money was also appropriated for the publication of a handbook to be prepared under the direction of Professor William A. Henry, dean of the College of Agriculture, State University of Wisconsin. During the summer and fall of 1895 Professors Henry, King, and Goff spent much of their time in the north making careful examinations of the several districts with reference to their soils, the kinds of crops adapted to soil and climate, the possibilities of livestock production, dairying, sheep raising, fruit growing, etc. They made a fairly complete general agricultural survey of the northern part of the state, taking as their starting point a line drawn from Green Bay to Hudson on St. Croix River. The material arranged by Professor Henry was published in 1896 in a book containing nearly 200 pages and fully illustrated with cuts made from photographs taken in the course of the survey. It was called Northern Wisconsin, $A$ Handbook for the Home Seeker, and is without question the most valuable single source of information in regard to northern Wisconsin at that time. It was distributed by means of the State Board of Immigration and also through immigration bureaus established in 39 northern counties, including all of the 2.9 which we have called the New North. 
Professor Hemry found agriculture well advanced at some points along his dividing line drawn from Green Bay to Hudson. But at other points, especially in portions of Clark and Wood counties, conditions were still decidedly primitive "owing to the heavy hardwood forests which once entirely covered those sections." The same cause, a heavy covering of hardwoods, delayed the settlement of other great areas, as for example the huge belt of territory extending north from Portage and Waupaca counties and including large portions of Shawano, Marinette, Langlade, Forest, Oneida, and Florence counties. ${ }^{11}$ There were other large tracts covered with hardwoods, but since the hardwood timber was coming into demand and mills for its manufacture were springing up in many localities, settlers on those lands frequently found ready sale for their timber at prices which often left a profit after clearing the land. ${ }^{12}$

Accordingly, Professor Henry did not hesitate to recommend the hardwood lands to settlers who were willing for some years to combine woods work with farming. Many of those lands, in fact, were taken up for homes by men who began as woodsmen, working for mill companies. As landowners they continued to fell trees and get out logs for the mill, but they now sold logs rather than day's labor, and every tree that crashed to the ground let in more sunlight to warm the soil and get it ready to produce crops. Thousands of sturdy Northmen, many Germans, and other foreigners, and some native Americans changed their condition in this way from hired laborers to independent owners of valuable farms.

Large tracts of forest, both pine and hardwood, from time to time had been burned over. Such a burned area was in appearance most forbidding. It showed gaunt, ghostly looking dead pines still erect, giant trunks burned off at the base and in falling arrested by other dead but standing timber,

"See William A. Henry, Northern Wisconsin, A Handbook for the Home Seeker (Madison, Wis., 1896), 72.

${ }^{12}$ Hardwood timber, which could not be floated on the streams like pine, waited for its exploitation and marketing upon the construction of railroads into the hardwood areas. 
half-buried logs overgrown and hidden by underbrush or by groves of saplings; in short, timber living and dead inextricably intermingled and nearly all worthless. Such a tract, in such condition, was costly to clear and brought little or no return for the wood taken off. Sometimes, however, a "double burn" occurred. That is, a burned-over forest such as we have just described would burn under a strong wind a second time. Now the dry dead timber served the purpose of helping to consume the green, stumps and all, leaving the land after the fire had passed practically clear so that much of it could be gotten ready for the plow at a nominal expense of about $\$ 1.00$ per acre.

Such land was the next thing to prairie. In fact, it probably was prairie in the making. Those who took it for farms were hardly in worse case, as regards the labor of clearing, than the immigrants to North Dakota or western Nebraska, while on the double-burned lands of Wisconsin they were sure of firewood, sure of rainfall, sure of crops, and sure of a market for their products. This explains the popularity of such lands and the rapidity with which they settled up, once northern Wisconsin began to be looked upon as a farming country. ${ }^{13}$

Last of the three great classes of timbered lands to be taken for farming was the cut-over pine lands, covered with pine stumps. In certain sections, it is true, pine grew on light, sandy, bowlder-strewn or gravelly soils, which were of little value for farming. But in general the soil of the pine lands was quite as good as that covered with hardwoods, the prevailing belief to the contrary being largely a prejudice brought by Wisconsin people from the East. One reason why settlers thought lightly of these cut-over lands was that the lumber companies thought too little of them to retain title after the timber was gone, allowing them to be sold by the county for taxes. ${ }^{14}$

u The great fire of 1871 practically cleared most of Door County, together with portions of Brown and Kewaunee. Other great forest fires also have an historical relation to the settlement of large tracts.

${ }^{14}$ Later, land companies began to pay up the taxes on such lands and to receive from the counties certificates of tax payments known as "tax-titles." These titles they gave to homeseekers who bought of them. 


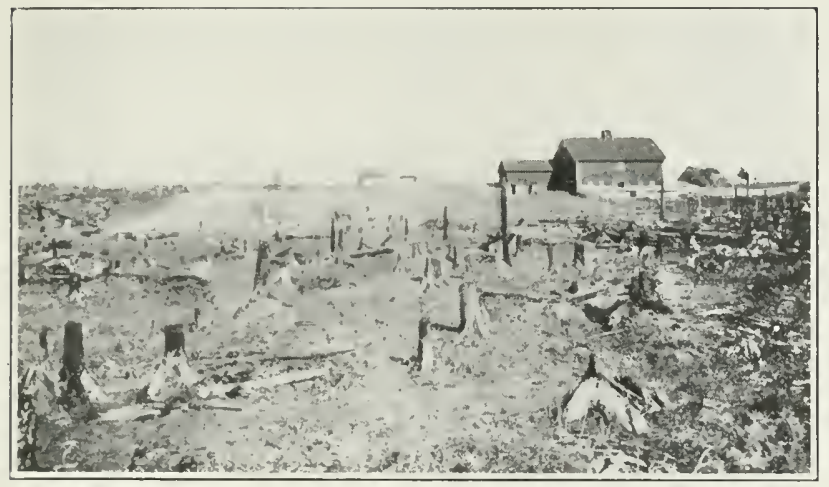

A PARTIY CLEARED FARAS ON CUT-OYER IANDS

From Henry's Vorthern Wisconsin

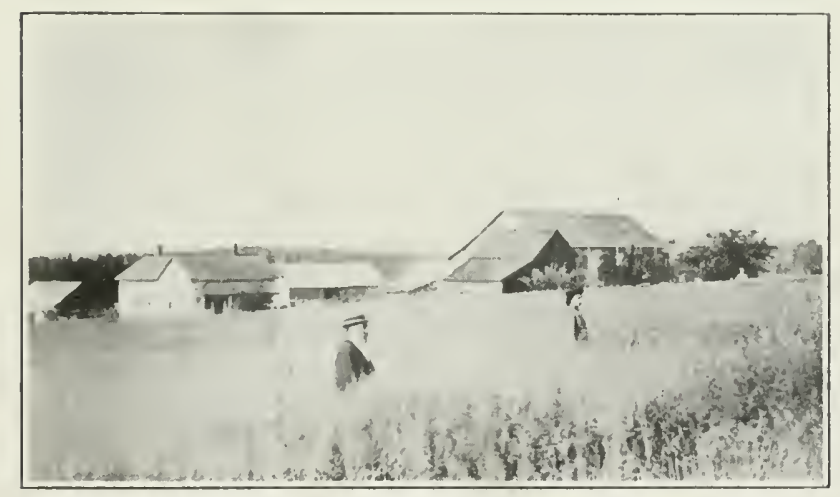

A MARATHON COLNTY FARA- NOTE OAT FIELD

From Henry's Northern Wiscomsin 


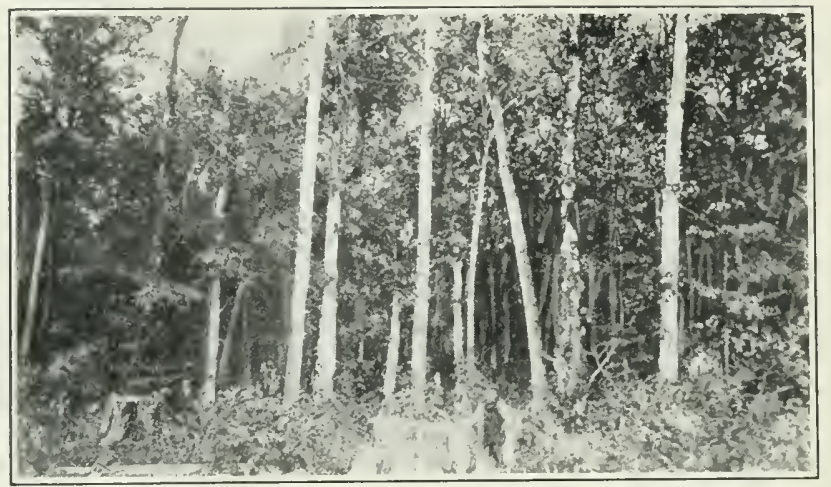

A HARDTOOD FOREST IN FLORENCE COUNTY

From Henry's Northern Wisconsin

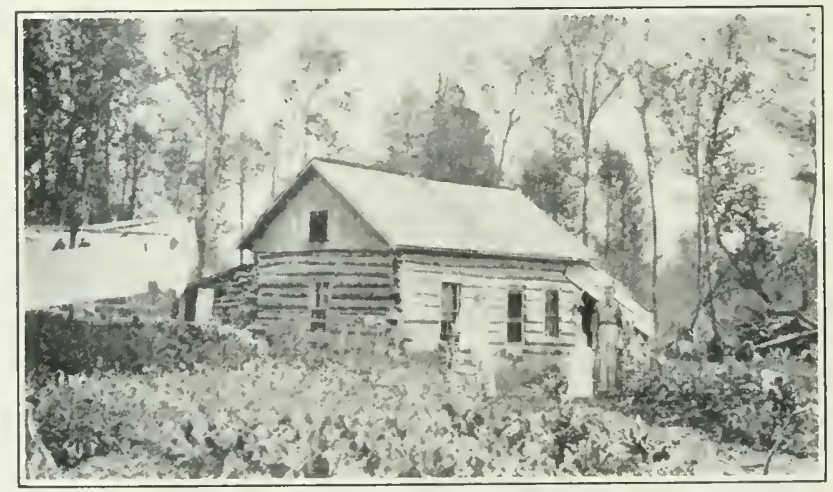

A NEW IIOSLE IN THE NORTII

from Henry's Northern Wisconsin 
Pine stumps will last nearly a hundred years, whereas the usual hardwoods rot out entirely within less than one-fifth of that time. There was no encouragement to take cut-over pine lands and wait for the stumps to rot away. However, it was found that after a few years their earth gripping rootlets decayed, making it much easier to lift or blow the stumps out of the ground. Stump pullers operating on the lifting plan have been used with considerable success. However, experiments by the College of Agriculture and by individuals have finally demonstrated the economy of using dynamite for clearing such land, and they have also shown what grade of explosive should be used for best results. The expense depends on the size and number of stumps per acre, also on the length of time during which their rootlets have been decaying. There is stump land which would cost $\$ 100$ per acre to clear, though much of it would cost less than half that amount. Of course, at the higher figure men can afford to stump only the best of the pine lands.

The soils of northern Wisconsin were grouped by Professor Henry under seven classes-sandy soil, sandy loam, prairie loam, clayey loam, loamy clay, heavy red clay, and swamp or humus soil. The greatest body of sandy soil is found in Monroe, Jackson, Adams, Juneau, Wood, and Portage countiesthe great triangle in the Driftless Area covered with weathered sandstone soil unmixed with glacial material. ${ }^{15}$ The lightest of these sandy soils requires irrigation for successful cropping. But not all sandy soils are equally light. Loamy sand is usually excellent, easy to clear, easy to work, warm, and responsive. With careful farming, to restore fertility as fast as crops consume it, such lands make excellent farms for certain crops, for sheep and other stock, though they are not of first quality for dairying because they produce grass too gingerly.

The sandy loam type he found much more widely distributed over the north than the sandy soil. It covers most of the

${ }^{16}$ See p. 8. 
glaciated portions of the state which are underlain by the upper Cambrian sandstone, the soil being a mixture of the materials brought from the north and spread over the surface by the glacier and the weathered sand from the Cambrian foundation. The greater part of Waupaca, Waushara, Marquette, portions of Monroe, Jackson, La Crosse, Trempealeau, most of Eau Claire and Dunn, and part of Chippewa County are covered with the sandy loam soil. Buffalo, Pierce, Pepin, St. Croix, and Polk have mostly clayey loam. Outagamie has heavy red clay and clayey loam.

In the great area of the crystalline rock formation ${ }^{16}$ the soil is mostly a clayey loam except in the valley and about the headwaters of Wisconsin River, where are sandy soils, sandy loams, with swamp or humus about the hundreds of lakes and marshes. Light soils also cover a strip from Menominee River to Green Bay, while Brown, Kewaunee, and Door counties have mostly red clay, clayey loam, and loamy clay. The Lake Superior slope also has the heavy red clay-a strong, enduring soil, somewhat stiff to work but which was found to be greatly benefited by thorough underdraining. The ridges between the rivers flowing to Lake Superior and those flowing south contain a good deal of light, sandy, and stony soil not very valuable for farming. The working of the iron and copper deposits in that region is one of the causes, in addition to lumbering, that has built up Lake Superior cities, which in their turn have stimulated the development of farming to supply the market for all manner of farm products.

When Henry's survey took place, in 1895, only the beginnings of agriculture had been made along Lake Superior. The quarter-century which has passed since then has witnessed a great transformation, as the census of 1920 showed. The county of Douglas was credited with almost 50,000 population. Of these the city of Superior had 39,671 , leaving slightly more than 10,000 to be distributed over the rest of the county, mostly on farms though there are several villages aggregating

${ }^{16}$ See mar, r. 4. 
upwards of 1000. Bayfield County had an aggregate population of 17,201 , about 5300 of whom lived in villages, the balance on farms; while Ashland County, with an aggregate of 24,538 , had approximately 8000 living on farms, and Iron County had 5000 .

Regarding the 29 counties of the New North as a single region, we find that the population in 1920 aggregated 702,974, a gain in thirty years of 341,368 . A part of that gain was in the cities, for it is still true, as it was in 1895 , that the cities of the north are in advance of the country. But growth in recent years has been relatively more marked in the rural neighborhoods than in the towns. In twenty years the rural population increased 140,000, while the urban increased 45,000. In fact, northern Wisconsin was the only part of the state in which during the twenty years prior to the census of 1920 rural population had been increasing at all. Everywhere else it was stationary or even on the decline. In the north, with large bodies of good land still out of cultivation, a continuous, sometimes a rapid, influx of agricultural immigrants took place.

These immigrants were of all types, but the table of nativities, extracted from the last census and printed herewith, shows that a very large proportion were Scandinavians, including Norwegians, Danes, Swedes, and Finns. These four classes taken together made 43,707 of the total, the Norwegians being most numerous $(19,311)$, the Swedes coming next (15,881), the Finns third (5744), and the Danes last (2771). Of Germans there were 31,691, of Poles 13,740, and of Canadians 10,760. Other nationalities, as will be seen from the table, were negligible.

Those who have accustomed themselves to think of northern Wisconsin as a vast, undeveloped wood land, and have failed both to keep up with statistics of growth or to view the country at first hand, will be quite unprepared to appreciate the results of agricultural history in that region. It is startling to be told that Marathon County has a larger rural population 


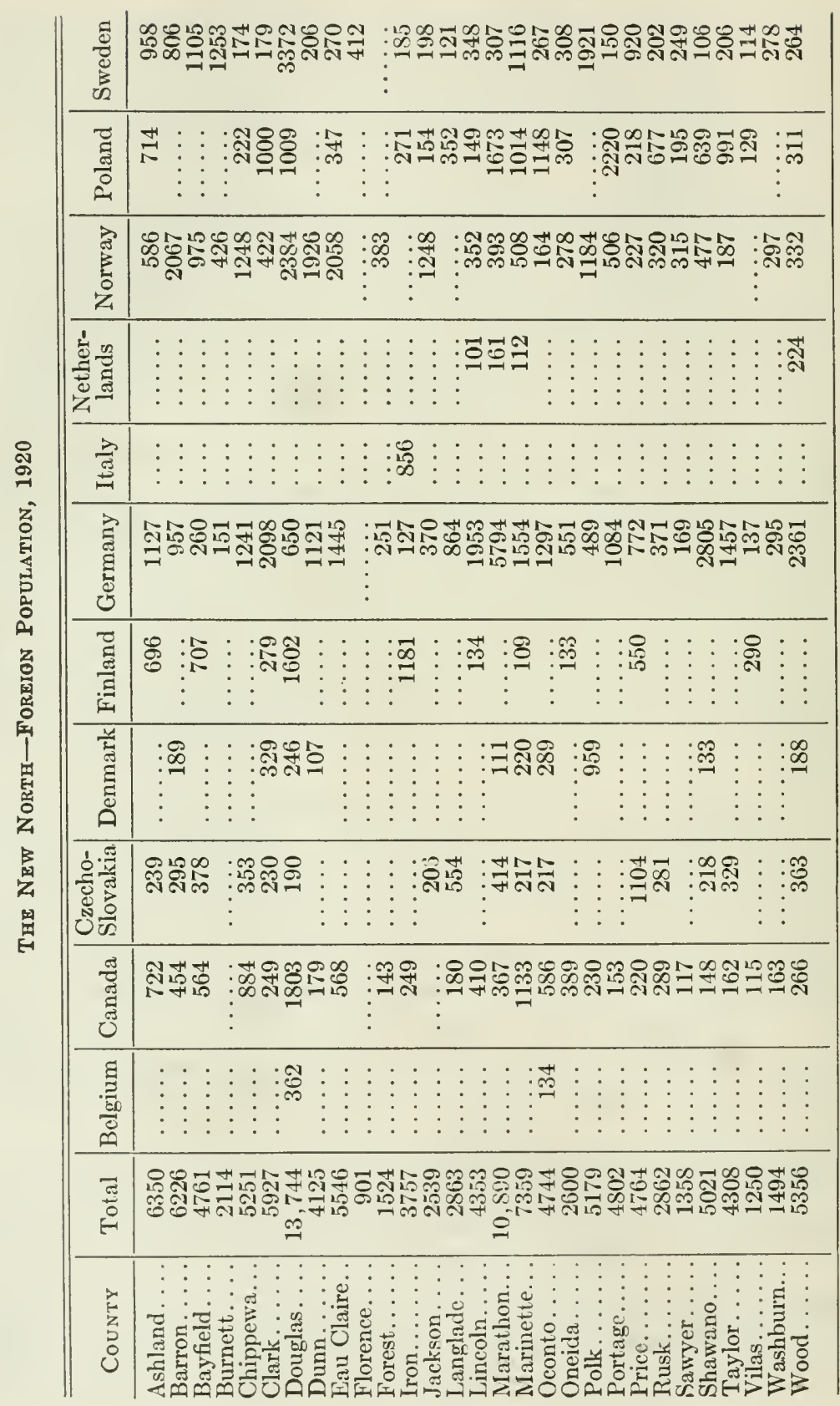


than has Dane County, yet such is the testimony of the census, which also shows that Marathon has the largest rural population of all the 71 counties in Wisconsin, 46,598, Dane standing second with 45,953 . There are in the northern group 3 other counties with 30,000 or more rural inhabitantsnamely, Barron, Clark, and Shawano; while 7 othersChippewa, Dunn, Marinette, Oconto, Polk, Portage, and Wood-have 20,000 or over. Only 5 of the 29 countiesFlorence, Iron, Oneida, Sawyer, and Vilas-have less than 10,000 rural inhabitants.

The record of agricultural progress in the several districts and counties of northern Wisconsin cannot be treated in detail. The Transactions of the Northern Wisconsin Agricultural Society, 1872 to 1887, throw a good deal of light on what the people were doing to promote better farming, particularly in the border counties between the north and the south. The headquarters of that society were at Oshkosh, and the annual fair was held at that place. Membership was not confined to the northern counties, and those north of Dane, Jefferson, and Milwaukee participated largely.

In one aspect the section we have called the New North presents today many of the contrasts which were to be observed in the older Wisconsin of the south and southeast in 1850. In the region are some of the finest farms in the state, with modern buildings, the best improved or purebred stock, and well tilled fields growing splendid crops of hay, grain, and silage corn. On such farms the old log house of pioneer days is often standing alongside of the new dwelling supplied with every convenience, including running water, plumbing, bathroom, and lighting. On the other hand, this is the region where the mud-daubed log house and the temporary board shack are still in use as homes of families. Northern Wisconsin is still a land of promise to the pioneer, and new homes are rising daily in the hardwoods and among the decaying pine stumps. It is a land of rural contrasts in other respects as well as in the homes and the farms. There are districts having 
the one-room log schoolhouses characteristic of the primitive days all over the older West. Yet, no section of the state has made greater progress in establishing the consolidated type of rural school, with thoroughly equipped school building, graded course of study, library, and high school facilities, which with well trained teachers is the true solution of the educational problems of rural communities.

Northern Wisconsin is a land abounding in wild game and in streams and lakes teeming with fish. These allurements, coupled with its remaining forests, its diversified scenery, and temperate summer climate, have made it one of the summer playgrounds for tourists from southern Wisconsin and most of the Mississippi Valley states. Good roads and the automobile have played a decisive part in developing the tourist trade, which is a unique feature of life in the region. It is comparable to nothing in the experiences of the older Wisconsin communities, and its social as well as economic influence will be watched with deep interest. 


\section{CHAPTER IX}

\section{THE AGRICULTURAL REVOLUTION}

A reported incident, for the substantial correctness of which I can vouch personally, throws much light on the condition of Wisconsin dairying during the period prior to the adoption of the factory system. Sometime in the seventies the storekeeper of a Grant County village received a visit from a traveling butter buyer who examined the accumulated supply of summer butter kept in the cellar under the store. He pierced with the trier firkins, jars, rolls, and "pats" of the golden hued if not gilt edged product, sniffing and tasting as he passed from one lot to the next. Finally, after the examination was completed, he said to the merchant: "Well! All I can offer is six and a fourth; now you may take it or leave it."

"No!" shot back the other. "You give me six and a half and take it or leave it."

The buyer, slowly, "Well-I'll take it."

Thus passed, perhaps to the last middleman before it reached the ultimate consumer, the summer's dairy product of a considerable farming neighborhood. The butter had been bought at from 5 to 10 cents and the sale price of the job lot would not have covered the original cost to the storekeeper, who relied for compensation on the profits of the goods sold in exchange for the butter.

The chief obstacle to success in dairying under the old régime, particularly throughout the interior of the state, was the marketing problem. The sole dealer to whom the average farmer, or farmer's wife, resorted was the keeper of the village store, who commonly took butter, as he took eggs, salt pork, lard, and smoked meats, in exchange for groceries and other goods. In most cases buying butter was merely an accommodation to his patrons, and it goes without saying he 
was not in position to grade the product strictly or to pay in accordance with the standard of excellence producers maintained. Much, very much, of the butter carried to the stores in the summer season was unfit for human food, and in fact was ultimately sold for grease at a few cents per pound. The good butter, properly packed in clean wooden firkins or in stone jars, could be disposed of at a higher figure. The merchant hoped to recoup himself from the sale of the better product for the losses he inevitably sustained on the worse; but like the instance recited above, he probably in most cases lost money on the aggregate, or would have done so but for the margin of profit taken on exchange goods.

Under that system of marketing, farmers had no encouragement to prepare for dairying by providing a proper dairy house, with desirable equipment for making the best quality butter; little thought was given to the herd, its breeding, housing, winter feeding, pasturing, and general management. In a word, dairying of the kind which depended on the country store for its market lacked every element of sound business and was merely incidental to providing milk and butter for the farm home.

Such dairying had been carried on from the beginnings of agriculture in Wisconsin. Whenever a farmer resolved to make dairying an important feature of his operations, the first step was to find a more satisfactory market than the store. There were several ways of doing this. One was to establish a reputation for fine butter and then sell, at a contract price, directly to private families. The village doctor, lawyer, teacher, and banker-frequently others also-were glad to pay more than the store price in order to make sure of nice, savory butter for their tables. It was no uncommon thing for such patrons to pay 25 or 30 cents per pound cash the year around, for butter which would have brought at the store 10 cents in summer and 20 cents in winter. Under the stimulus of such a market, although it was sharply restricted, farmers here and there began to improve both their dairying practises and their herds. 


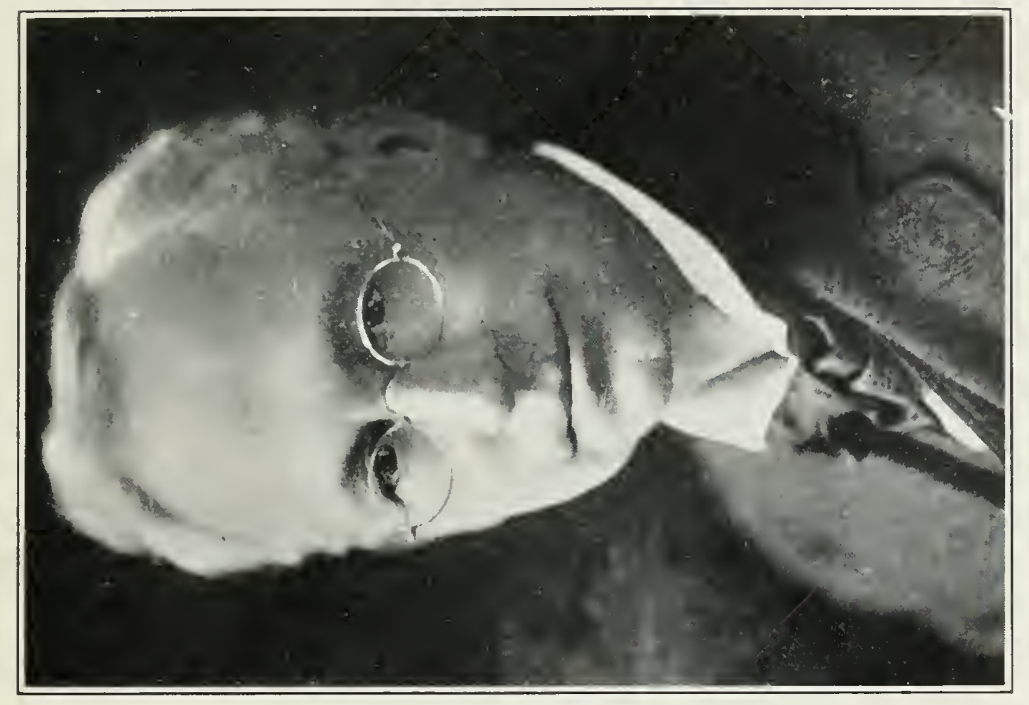

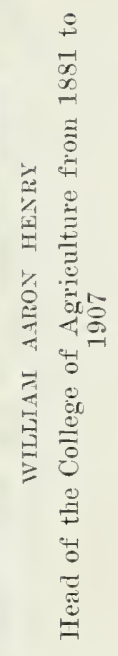

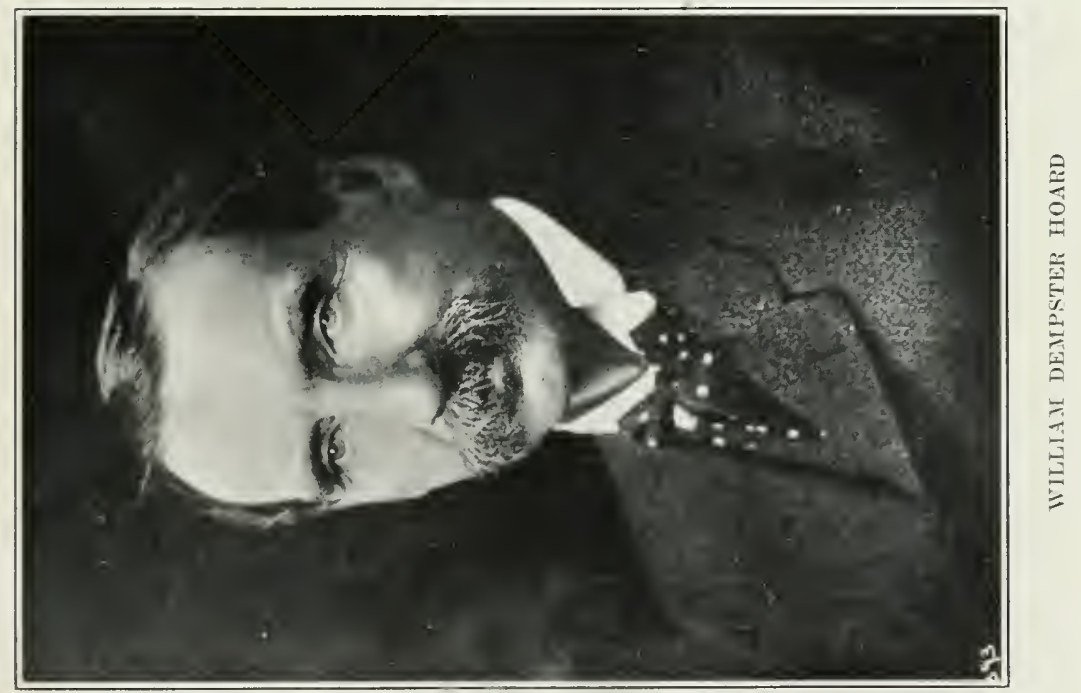




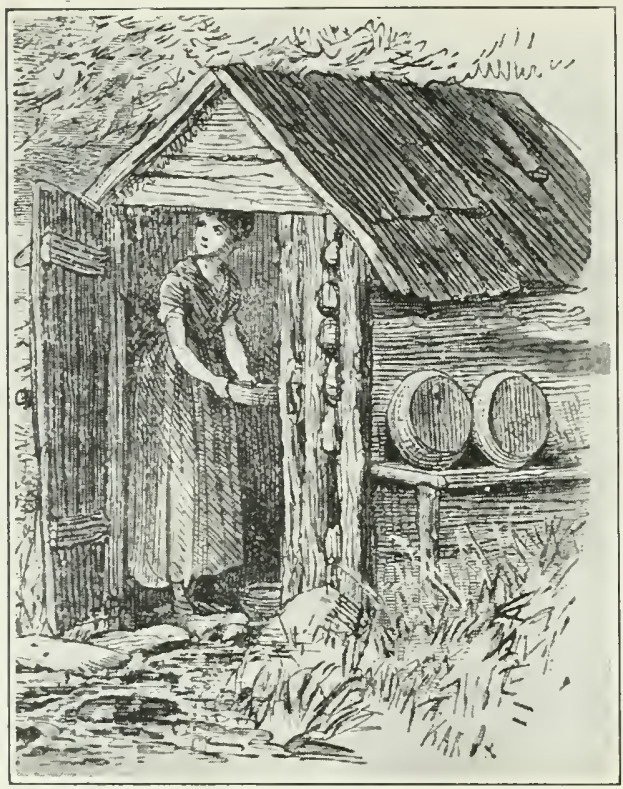

A FARME "SPRING HOUSE"

From Eggleston's A Circuit Rider

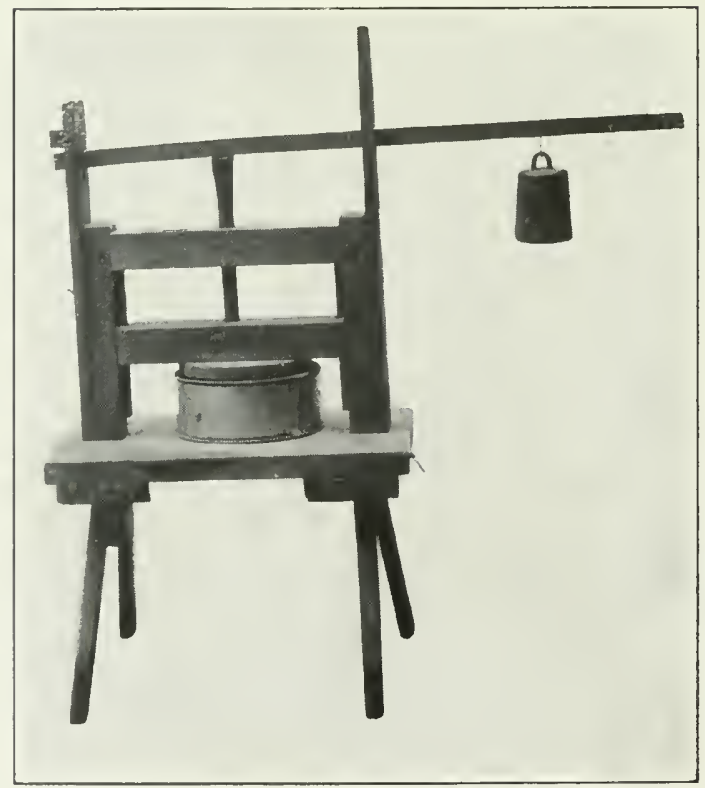

A PIONEER IIOUSEHOLD CIIEESE PRESS USED IN RICHLAND COUNTY

Original in State IIistorical Museum 
Another method was to sell no summer butter in summer, but to pack it carefully and keep it under such conditions as to make it marketable in fall, at a fair price, for shipment to city commission houses. To do that required either an exceptionally cool, well ventilated, and clean cellar, or else a "spring house," the latter being preferable. The abundance of beautiful springs of pure cold water in many sections of the state made the stone or wooden spring house, with its deep troughs of flowing water, a not infrequent attribute of Wisconsin farms, though naturally only a small percentage of the whole were thus equipped.

Farmers living in the vicinity of the large cities had special inducements to make their dairying count in the annual balance. For they were able to sell their butter either directly to consumers at a fair contract price, or to middlemen who distributed directly to consumers and could afford to pay well for a first-class article. It is not surprising that the farmers of Kenosha County; almost equidistant from Chicago and Milwaukee, should have been among the leading pioneers in improved dairying, as we find them to have been. For example, W. C. White of the town of Spring Prairie began butter dairying on a considerable scale as early as 1857, changing over to cheese a few years later. ${ }^{1}$ Others in the same county were almost equally prominent. The 1860 census presents the names of three Kenosha County farmers who, in the preceding year, made over 2000 pounds of butter apiece. They were W. C. White, Pleasant Prairie, 2800 pounds; Philip Gascoyne of Somers, 3000; and Nicholas Kichtneys (probably Kichtmyer), 2100. The aggregate production of several Kenosha towns was very large, Brighton having 37,708 pounds, Bristol 47,610, Paris 56,256, Pleasant Prairie 68,567, Somers 66,627,

${ }^{2}$ Mr. White began making cheese in 1860. See Wisconsin Dairymen's Association, Report, 1879, 124. Mr. White, it is said, was responsible for the dairyman's slogan, used so effectively at farmers' institutes thirty years later: "Speak to a cow as you'd speak to a lady." The writer saw that admirable sentiment painted on a streamer which draped one side of the hall in which the Boscobel farmers' institute was held February, 1887. The opposite wall was decorated with a streamer of equal length bearing this significant comment on the above: "But don't speak to a lady as some men speak to a cow." 
Salem 47,680, Wheatland 32,188, and Randall 19,183. The heaviest production was in the two lake front towns of Pleasant Prairie and Somers; the lightest in the two westernmost towns, Wheatland and Randall. The aggregate butter production for the 8 towns was 376,620 pounds. Fifteen other Wisconsin counties produced more than that amount of butter. But if the population is taken into account, Kenosha was the largest per capita producer of butter, with one exception, of the 16 counties producing more than 300,000 pounds. The exception was Green County, which produced $34+$ pounds per capita as against $27+$ pounds for Kenosha. If, however, we limit the competition to rural population strictly, Kenosha's per capita production is a fraction of a pound higher than Green's.' Contrary to current belief, Kenosha also produced more cheese than did Green County, or any other county. ${ }^{3}$ But the most significant fact revealed by the census is that a few farmers were really making a business of dairying.

The counties in which by 1860 dairying was beginning to be carried on intensively were, in addition to the two named above, Racine County, which made approximately 35 pounds per capita of the rural population, and Milwaukee and Walworth, where the per capita production of butter was almost exactly 25 pounds. Each of these counties made a small amount of cheese, Walworth's quota being the largest of the three.

Intensity of production, however, may mean merely what, for example, it meant in the case of Milwaukee County and less pronouncedly in Green County, namely, that practically all farmers kept a few cows and made butter or cheese, of course wholly under the household system of manufacture. In view of the development which became so marked a few years later, it is interesting to scan the census of 1860 for evidence of a tendency to make dairying an exclusive or principal

\footnotetext{
${ }^{2}$ Kenosha, with a rural population of 9527 , produced 378,966 , making the average $38 \%$ ' nearly; Green County's rural population was 17,660 , her aggregate 673,966 , or an average of $381 \%$.

${ }^{3}$ George DeLong of the town of Somers made 1000 pounds of butter and 6000 pounds of cheese. He had 29 mileh cows, while White had 23 and Gascoyne 16.
} 
business, of proportions which would call for special methods prophetic of the factory system.

We have already noted something of the kind among the butter makers of Kenosha County. Examples have also been found in other counties. In Walworth John W. Newton of the town of Geneva kept 32 cows, making 400 pounds of butter and 10,300 pounds of cheese. P. A. Price of Rock County; near Janesville, made from 50 cows 600 pounds of butter and 25,000 pounds of cheese. Milton Barber of Waukesha, from 66 cows, made 10,000 pounds of butter and 10,000 pounds of cheese. J. V. Robbins of Burke, Dane County, had 115 cows and made 4000 pounds of butter and 6000 pounds of cheese. There were in Jefferson County three herds of 21, 30, and 32 cows producing respectively 6000,3000 , and 7000 pounds of cheese, besides 500,1000 , and 800 pounds butter. One of these belonged to Asa Favill. ${ }^{4}$ Fond du Lac also had three distinguished herds of 25,31, and 37 cows credited with both butter and cheese. In Green County, George Legler of New Glarus kept 29 cows, making 1000 pounds of butter and 3000 of cheese; there was a larger herd in the town of York, 36 cows, credited with 1800 pounds of butter and 6500 pounds of cheese. Sauk County had one large herd, 41 cows, but the product divided between butter and cheese was very light.

From the above survey it will be seen that dairying by 1860 was well begun within the limits of the older Wisconsin; that it tended to become a regular business among a select group of farmers who were widely scattered mainly in the southeastern and southern counties; and that the suggestion of a factory system of production existed particularly as regards cheese making. But the rank and file of Wisconsin farmers were still carrying on in the old way, careless of the character. of the cows, of the way they were kept, of the milk, cream, and butter, of the method of selling the product.

- This Favill was an uncle of Stephen Favill of Lake Mills, one of the founders of the State Dairymen's Association and a prominent cheese manufacturer for many years. 
It is a far cry from that state of things to the Wisconsin dairying of thirty years later, and the story of building up the dairy interest in that interval provides the leading feature of recent agricultural history.

The forces which operated to bring about the great and fundamental changes so easily recognizable were mainly four: the influence of the New York example; the leadership of New York men; the scientizing and organizing agency of the College of Agriculture; and the whole-hearted coöperation in the practical execution of plans and policies of Swiss, German, Scandinavian, and other farmers of foreign extraction to whom, more than to the native American element, the leaders learned to look for the daily exemplification of good methods and the elimination of bad practises.

A speaker at the convention of the State Dairymen's Association in 1875 said: "Thirty-five years ago the bulk of the dairy product of America was made in central New York." 5 That statement involves a certain exaggeration, inasmuch as New England, other middle states, and especially Ohio were producing much butter and some cheese. Yet, there can be no doubt that it was New York's surplus production upon which, about 1840, the country began to rely for its supply of butter and cheese. Indeed, the demand could not be wholly met from that source, and English cheese continued to be imported to some extent until with the inordinate growth of the New York cheese crop after the introduction of the factory system in 1851 and the contemporary drop in production abroad, due to the cattle plague, the foreign market was opened to American cheese. The New Yorkers who came to Wisconsin in such large numbers from 1837 to 1850 knew something about the beginnings of a more scientific-at least a more business-like - system of dairying; while others, like the late ex-Governor Hoard, who came in the fifties, had had personal contact with a movement for improved agriculture under the dairying impulse which was similar in many respects to what we have

' C. H. Wilder, Wisconsin Dairymen's Association, Report, 1875, 30. 
seen in this state under such leadership as that of Mr. Hoard. The reports of the New York Board of Agriculture, the columns of the agricultural press, especially the Rural New Yorker, the lectures of scientific agriculturists, all described with enthusiasm the doings of dairymen in Herkimer, Oneida, Cayuga, Ontario, and other central New York counties. Their herds, chiefly Durhams and Devons, were held up as examples of good breeding, their barns and dairy houses were pictured for the instruction of farmers elsewhere, their methods of manufacture carefully set forth.

Except to those who are unaware that people from the Empire State were so dominant in Wisconsin, there is no mystery in the fact that it was most frequently New York men who headed local movements for the building of cheese factories, for organizing breeders' associations and other means calculated to develop the dairying interests. A study of the beginnings of a new type of butter and cheese business in the several counties shows the New Yorkers to have been even more exclusively responsible for the results than Vermonters were for the spread of merino sheep or Morgan horses. In Kenosha W. C. White, in Sheboygan Hiram Smith, in Jefferson Stephen Favill, in Fond du Lac Chester Hazen, in Walworth R. McCutcheon, in Rock C. H. Wilder, in Dane E. P. Sherman, in Waukesha B. M. Hinckley, in Richland John A. Carswellthese are some of the local leaders, and nearly all of them were immigrants to Wisconsin from central New York. ${ }^{6}$

A good specimen of the outworking of the New York influence, through example, is found in the way factory cheese making spread from Bear valley in Richland County to other parts of that county and to Grant County. A group of central New Yorkers was settled in Bear valley in the fifties. Among them were the Carswell brothers, the Beckwith brothers, H. L. Eaton, and others. Another New Yorker, L. G. Thomas of Herkimer County, started what is supposed to have been the first cheese factory in southwestern Wisconsin, near Lone

- Hiram Smith was a Pennsylvanian. 
Rock in 1865. ${ }^{7}$ Two year's later the Carswell factory was begun, the next year the Beckwith factory, the next the Eaton factory, till Bear valley, which once grew wheat and hops, was densely populated with cows. Its farmers were prospering as dairymen, while all around in the neighboring valleys of Richland, Grant, Sauk, and Iowa counties were mortgaged farms whose owners were dubiously contemplating emigration to the West as perhaps the only means of relief. Northern Grant County had no factory prior to the organization in 1881 (possibly it was in 1880) of the Oak Grove factory in Blue River valley. That factory was started by H. Z. Fish of Herkimer County, son of a noted New York dairyman, with another Herkimer man as maker. It could not have been started, however, but for the Bear valley experience, which was brought to the farmers of the Blue River and Fennimore valleys by one of their own number whose brother was a prominent dairyman of Bear valley. ${ }^{8}$ That was the influence which induced farmers to subscribe cows enough to make the factory at Oak Grove pay. And the same influence enabled Mr. Fish to start several other factories in addition to that one. In a few years the whole region was supplied with cheese factories, whose combined product was sold by a coöperative board of trade located at Muscoda.

When W. D. Hoard in 1870 began publishing the Jefferson County Union at Lake Mills, there were possibly not more than 45 or 50 cheese factories in Wisconsin. ${ }^{9}$ Having come in

\footnotetext{
'See William D. Hoard, "History of the Dairy Interest in Wisconsin," Wisconsin Dairymen's Association, Report, 1879, 126.

8 The local farmer was James A. Black. He was of Virginia stock and a natural leader of men. But the story he told the neighbors, as lie drove around the valley with Mr. Fish, was how surcessfully the factory cheese making system had worked out "over on Bear Creek" as testified by his brother J. Q. A. Black and as he had personally observed conditions there.

- In the Transactions for 1870, published in 1871, Dr. J. W. Hoyt, secretary of the Wisconsin State Agricultural Society, caused to be printed tables exhibiting the manufactories of all the counties of Wisconsin. In these are included cheese factorics, but unfortunately the number of factories is not stated save sometimes when there is but one. We are given the capital invested, pounds of cheese made during the year, and the value of the products. We find, from that source, that one or more factories existed (presumably in 1870, though one cannot be certain that new creations of 1871 were rigorously excluded) in Dane, Dodge, Fond du
} 
1857 from Madison County, New York, and being in close touch with New York conditions, he was interested in promoting dairying in Jefferson County in accordance with Madison County examples. From news items about dairying progress he passed to editorial comment, and very soon his dairy column contained the most analytical, trenchant, and enlightening discussion of dairy problems. Since the ideas Mr. Hoard advocated were ultimately promulgated by others also and became dominant in the state, the most effectual method of revealing the features of Wisconsin's dairying development is to give some account of those ideas as Hoard presented them, first in the Jefferson County Union, then in Hoard's Dairyman, and meantime at hundreds of farmers' institutes, dairymen's conventions, and other gatherings of farmers.

Hoard saw that the fundamental problem confronting Wisconsin farmers was the problem of marketing dairy products, especially cheese. Western markets, by 1872 , were becoming glutted and it was necessary for Wisconsin manufacturers to break through into the eastern and English markets. This feat, no light one in the days when Wisconsin dairymen were without influence and New York's competition was so overshadowing, was accomplished through the agency of the Wisconsin Dairymen's Association, organized in February, 1872, primarily for that purpose. ${ }^{10}$

Lac, Green Lake, Jefierson, Kenosha, La Crosse, Lafayette, Monroe, Outagamie, Bichland, Rock, Sauk, Sheboygan, and Walworth-16 counties. The largest investment in that line of manufacture was in Fond du Lac County, $\$ 26,300$, where the product amounted to 441,842 pounds valued at $\$ 62,819$. It seems probable that these figures represent some half dozen factories at least. Other counties which appear to have had several factories each are Green ( $\$ 11,000$ invested), Green Lake $(\$ 12,200)$, Jefferson $(\$ 18,000)$, Kenosha ("cheese factory' - $\$ 7820)$, Rock $(\$ 15,500)$, Sheboygan $(\$ 12,500)$, and Walworth $(\$ 14,500)$. From this showing, the estimate of 50 factories appears not excessive. It may be too low. Hoard himself in 1873 estimated the number in 1870 at more than 100.

${ }^{20}$ The first activity of the Association was to establish market days at Watertown, where Wisconsin manufacturers could meet eastern commission men and learn what the market demanded in the way of quality, uniformity, and mode of packing the product. Chester Hazen of Ladoga, Fond du Lac County, whose factory was perhaps the first one established in the state, 1864, was the first manufacturer of Wisconsin cheese to ship his product to the English market. This he did, it is believed at Mr. Hoard's suggestion, in 1873. 
Then there was the problem of proper curing vaults for summer cheese, in order to preserve the flavor, and $\mathbf{M r}$. Hoard wrote editorials, visited sub-earth vaults in other states, and finally induced the McCutcheon firm to make the Wisconsin experiment which proved successful. By that and other methods of curing, Wisconsin's summer cheese could be put upon the market under conditions enabling it to compete with cheese produced in cooler summer climates, largely to the benefit of Wisconsin producers. Another problem was to cheapen the cost of winter feed for cows. Mr. Hoard contended during many years that Wisconsin was in a position not only to produce butter and cheese of equal quality with that of New York, but to produce it at a lower cost because land was cheaper, cows were cheaper, and feed was cheaper. But he was never disposed to let well alone, and when he saw in the silo, a French invention, the means of reducing the feed cost he was quite as prompt to seize upon it as were the dairymen in New York. The result is physically apparent to anyone who crosses the state, by rail or vehicle, in any direction, in the uniformity with which farms are equipped with one or more, usually two, silos.

Perhaps the greatest stroke of policy in which Mr. Hoard led was the policy of "breeding sharply for milk" and paying less attention to the beef end of cattle raising. He insisted, with sound logic, many variations of statement, and convincing illustrative stories, that those types of cattle which had been bred longest and most consistently for milk, butter, and cheese were the breeds for dairy farmers to specialize in. Wisconsin farmers had so long regarded the Durham and Devon, especially the former, as the breeds through which to improve their herds, that the prejudice in their favor was hard to uproot. By untiring though by no means wearisome preaching even that feat was accomplished. The "dual purpose cow" was given no chance to fasten herself upon Wisconsin farmers, as she has been foisted by bad leadership upon 
the dairymen of some other states. That fact goes far to explain Wisconsin's preëminence in the dairy industry. ${ }^{11}$

If it is difficult to overrate the significance of leadership like that of Mr. Hoard, it becomes impossible to fix standards for determining the value to Wisconsin's dairy interest of the work done during many years, under distinguished leaders, at the College of Agriculture connected with the University of Wisconsin. That college, the fruit of the Morrill Law of 1862, was not without a struggle established as part of the University. The issue was finally decided in February, 1866, by a farmers' convention called by Dr. J. W. Hoyt, who was editor of the Wisconsin Farmer and secretary of the Wisconsin State Agricultural Society. The legislature, which was in session at the time and was partly pledged to establish the college elsewhere, practically accepted the convention's draft (which was Dr. Hoyt's draft) of a new fundamental law for the University, with the Agricultural College as an integral part of the institution. ${ }^{12}$ The result was hailed as a great triumph for scientific agriculture in Wisconsin. However, when it became apparent that the college educated practically no farmers, the attendance of students for some years being negligible, doubts arose in the minds of the farmers themselves, who feared the connection with the University was blighting the prospects of the college. They then initiated a movement to separate the college from the University, and to reëstablish it elsewhere than at Madison. That movement seemed not unlikely to succeed, but in the nick of time Professor William A. Henry, who had been on the ground a few years and was already a prime favorite with the farmers, started in January, 1886, the unique agricultural short course, the instant success of which forestalled further efforts to re-

${ }^{11} \mathrm{Mr}$. Hoard used to tell a charming story about a swift Morgan cavalry horse that enabled him to distance a detail of rebel troopers who would have captured him save for the animal's fleetness. Then he would ask, "What would have become of Hoard if that horse had been cross-bred with a percheron?" Moral: Breed for a purpose.

12 The senate roted to place the college at Ripon, or at least to give the agricultural college land grant to Ripon College. The house voted for the University, and in conference the senate receded. 
move the college. Henry's next great step was the inauguration of the winter Dairy School for the training of butter makers and cheese makers. That school, also the first of its kind in America, was opened in the winter of 1887. Within a few years trained young men, properly certificated, were turned out in sufficient numbers to man the new factories, and it then became unnecessary longer to depend on Herkimer County and other New York cheese makers or on their apprentices trained in Wisconsin factories.

The Dairy School, through the young men it graduated, made its anticipated contribution toward putting the dairy industry upon a scientific basis. But it did something more. Its teachers and research scientists themselves made contributions of incalculable value. Professor Stephen Moulton Babcock's milk tester solved a fundamental problem in marketing milk under the factory system with justice to all producers. It put the creamery on a new basis at once and greatly aided the cheese factory also. ${ }^{13}$ Professor Henry's Feeds and Feeding and Professor Russell's introduction of the bacteriological tests for the purification of herds from infectious diseases, especially tuberculosis, and his practical method of pasteurizing milk were only second in importance to the Babcock test in their influence on scientific dairying.

Through its extension division and its publication department the College of Agriculture became the greatest single agency of dairy education among the farmers, the promoter of organizations helpful to dairying as well as other branches of agriculture, and the clearing-house of experiments conducted on farms and in factories. Farmers' conventions,

\footnotetext{
${ }_{18}$ The creamery, or butter factory, was a later development than the cheese factory, and for obvious reasons. In making cheese the whole milk of many cowsseveral hundred at least-can be handled conveniently in two or three deep vats of large capacity. In these vats it can be heated, coagulated, and the curd prepared for the presses. For the purpose of butter making it is impracticable to handle whole milk beyond a certain minimum amount, too much space being required to set it for raising the cream. About 1879 the Fairlamb system of setting milk in graduated cans for creaming was adopted by some dairymen and by some creameries. Under that system farmers raised the cream and sold it by the inch, it being assumed that an inch of cream as shown by the gauge on A's can was as valuable for butter making as an inch on $B$ 's. But that was far from being the
} 


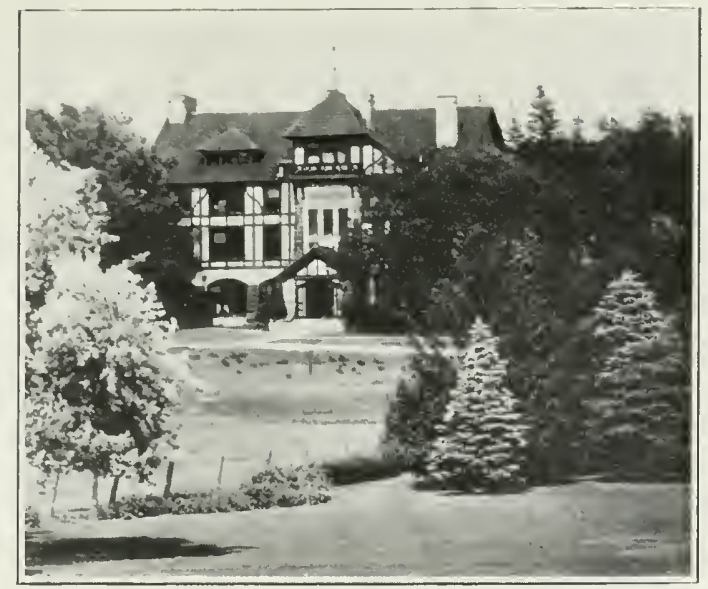

HIR.A SIITI HALL (THE DAIRT SCHOOL), UNAVRSITY OF WISCONSIN

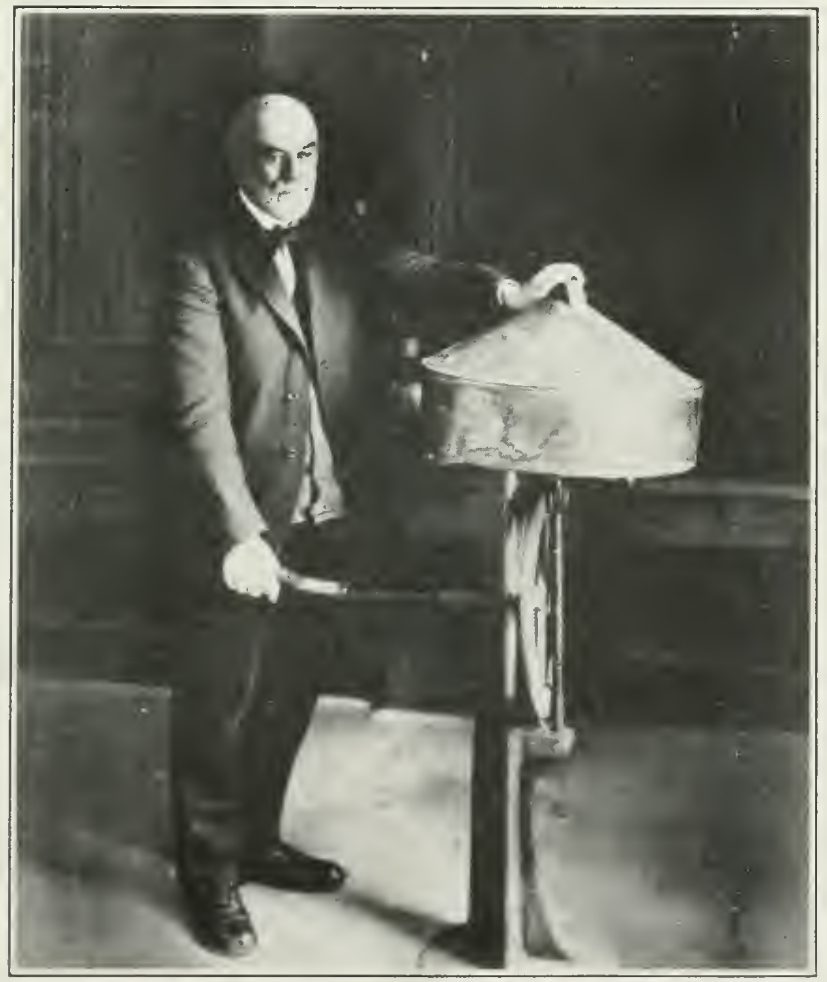

PROFESSOR STEPHEN MOULTON BABCOCK AND HIS MILK TESTFI 


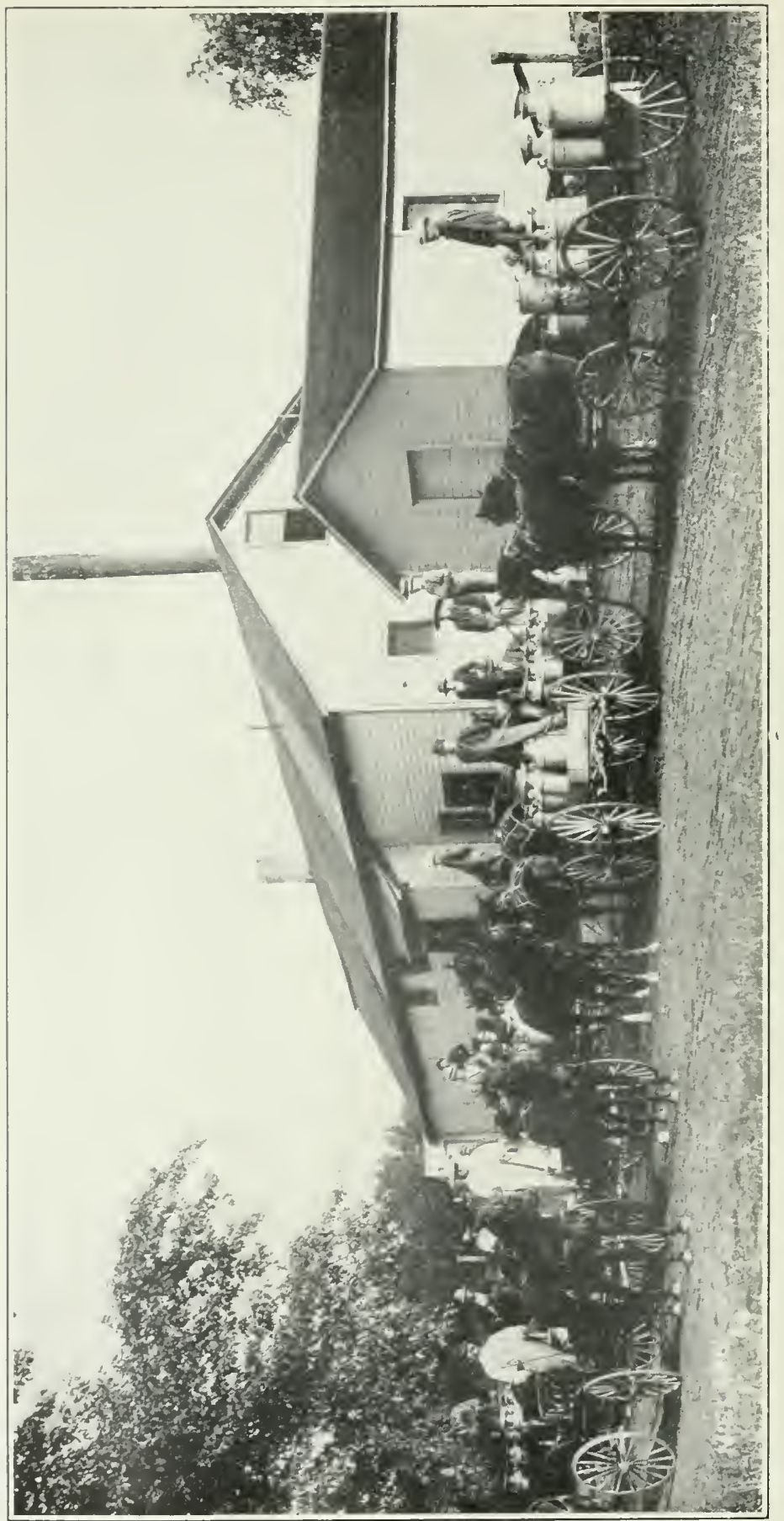

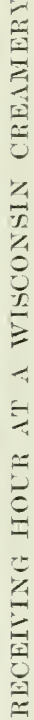


formerly held at the capitol under the auspices of the Agricultural Society, now came to be held at the University under college auspices. The farmers' institute, directed by the college, was established in 1886. From that year series of meetings were held in the several counties, which in character were mass meetings of farmers for the discussion of selected problems of agricultural improvement. Scientific men and practical farmers occupied the same platform, with the result that science was more closely controlled by experience and experience definitely guided by science. No other feature in the history of agricultural advancement, save possibly the more recent county agent system, has been so resultful in developing mutual respect and confidence between the farmer and the man of scientific learning.

The above are but a few, although perhaps the chief, ways in which the College of Agriculture has functioned to the benefit of Wisconsin agriculture, particularly dairying. If it were possible to imagine its influence withdrawn, especially in the period beginning with the early eighties, our picture of rural Wisconsin would be sadly altered.

It is a truism of military science that an army cannot be considered complete or fully effective unless the morale of its fighting forces is maintained constantly on a high plane. In Wisconsin, as elsewhere, the execution of dairying plans, policies, and scientific directions was in the hands of the milkers, feeders, and breeders of cows-the everyday, plain, hard working, often tired and discouraged farmers. It is one thing to test out a theory at the experiment station barn or laboratory, quite another to get it applied in farm practise. Some

fact. The milk tester was the only solution for the problem of how to do justice to producers of cream from the standpoint of its butter content. The question of the uniformity of quality in cream was profoundly affected by the introduction of the centrifugal mechanical cream separator. But separated cream still varies a good deal, depending on how it is managed. In the earlier cheese factories all milk was paid for at a given rate per pound or hundredweight. Since some milk had in it two per cent of butter fat and some six per cent, it follows that those contributing the richer milk were discriminated against. By the butter fat test that difficulty is removed and it is now often contended that the milk which is poorer in fat is discriminated against, considering its relative value for cheese. 
farmers are unresponsive, some are unintelligent, and a larger number are wanting in the moral purpose to persevere in doing a new thing under instructions, in the hope of a future contingent reward, which after all is the main condition of success. Native Americans, while keen, intelligent, and eager for the profits of every new adventure in agriculture, were by no means all willing to pay the price of success in dairying, which involved steady application to the business every day, week, and month in the year, which interdicted summer vacations, day and night fishing excursions, often even (before the arrival of the auto) daytime visits to not distant friends. Many of them refused to be "tied to a cow." Such farmers made a principal share of the troops of emigrants who moved during the late seventies and the eighties to new wheat areas like the Dakotas, selling their farms to newly arrived German, Scandinavian, or Bohemian immigrants. These new people became interspersed among those of the older American tradition who were willing to change their system of agriculture. Some rented farms, others hired out to Americans, but a goodly proportion bought farms either at once or after a few years' experience and saving.

In the end they became the guarantors of prosperity in dairying. ${ }^{14}$ For, to begin with, they were accustomed to work, hard and persistently, the long year through. They craved no vacations aside from the usual holidays to which they were accustomed. To them it was no hardship to milk twice a day, feed and tend the cows, and deliver the milk at the factory. All that was "in the day's work." Secondly, in beginning farming under a wholly new environment such as this country presented, they became of necessity pupils in a school of practise, glad to receive helpful suggestions from any source. They developed, as it were, a habit of experimentation which,

\footnotetext{
16 An editorial by Mr. Hoard which was reprinted by the Wis. Farmer, Nov. 14, 1874, refers to the economic advantage of dairying and makes the point that the chief objection to it-namely, that it requires attention every day in the year-is really one of the strongest arguments in its favor. It reduces the farming business to the "same law of success as any other." In any actual business one must invest his entire time if he would succeed.
} 
in the period when dairying methods were undergoing revolutionary changes, was highly important. Thirdly, they were generally thrifty, intent first on paying for their farms and then on amassing a competency. These motives made them keen to take advantage of every suggestion the profitableness of which could be foreseen. They were less prompt than the Americans to enter upon ventures which seemed speculative, like paying high prices for purebred breeding stock, but when observation had proved the economy of such expenditures they gradually accepted them as a part of the better farming program.

There is no disposition to minimize the part which native Americans took in carrying out the dairying program, for it goes without saying that thousands have been engaged in that work steadily and successfully. Neither is there any intention to deny to those of foreign birth a goodly share in the leadership, scientific and otherwise, which developed policies and secured their acceptance by farmers generally. The Swiss in Green County are a notable example of a group which adopted a special brand of cheese as the object of their enterprise and pursued its manufacture with extraordinary success. Many individuals among Germans, Scandinavians, and other foreigners performed notable service in the educational phases of the movement.15 On the whole, however, and by a kind of necessity, the first generation foreigners adapted themselves to plans made by the Americans rather than attempted either to impose or to carry out plans of their own. They were good coöperators and have been the basis of success in hundreds of factory associations. Their children and grandchildren, of course, are simply Americans, quite as likely to be the leaders in given communities as the descendants of the New York dairymen.

The new dairying, which is the product of historical forces whose workings have been clearly discernible for fifty years,

1s The late Hans Buschbauer, of Riverside Farm in Jefferson County, was a leading writer both on dairying and on other scientific phases of agriculture. His contributions appeared in the German press and the English also. 
and which owes to a few leaders a debt it is impossible to assess, has placed the state in the forefront of American dairy progress. By reason of it, Wisconsin farmers are in better case than farmers elsewhere over large areas. Even in times of severe depression the agricultural interests of Wisconsin remain strictly solvent, the cows managing always to pay their way. There are nearly $3,000,000$ of these cows at the date of writing. Their product, normally, is worth $\$ 300,000,000 a$ year! Among them, not in the character of a bovine aristocracy but rather as a substantial prophecy of the barn-yard democracy of tomorrow, are 80,000 purebred Holsteins, 20,000 purebred Guernseys, 8000 purebred Jerseys, and about 3000 purebred Ayrshires. Space forbids even the attempt to summarize the history of the introduction and spread of the dairy breeds which, with their grades, impart to the pastures of Wisconsin a distinctive character.

Most important of all has been the influence of dairying on the character of the farmer. Business principles, so painfully lacking under the old agriculture, have come to be universally applied in marketing products, and very widely also in the more prosaic features of farm management. The new dairying has made the average farmer something of a scientist, and a good deal of a business man. 


\section{CHAPTER X}

\section{FARM LIFE'}

Occupationally, farm life was more varied and colorful during the interval between universal wheat growing and universal dairying than in either of those two periods. It was an age of eager, almost feverish experimentation. Most farmers were in debt and had to produce something which would pay interest and taxes, or else sell out and go west. Some tried to outwit the chinch bugs by sowing their wheat mixed with oats, gathering the combined crop, and then separating the two kinds of grain by means of the fanning-mill. A few tried a recommended method of horse hoeing their wheat. Many raised barley and rye as market substitutes for wheat, others raised tobacco, others hops. In the lake shore counties, particularly the northern ones, field peas became a prominent and valuable crop. In all of them the growing of hay for market was a favorite pursuit. Some, who lived near the cities, found relief from the stress caused by the succession of wheat failures in market gardening. Horticulture had been widely practised as a household art, to provide home fruits on the farm, but except in a few cases not as a major enterprise. $^{2}$ Now, favored districts, especially the Door Peninsula, entered upon apple growing as a business, this to be combined in recent years with cherry growing. The northern frontier farmers raised hay, oats, and other supplies for the pineries.

${ }^{1}$ The greater part of this chapter refers to the middle or pre-dairying period, and some of the illustrative facts are drawn from the author's recollections of his own boyhood on a southwestern Wisconsin farm.

${ }^{2}$ A State Horticultural Society was organized about the beginning of the statehood period, under the leadership of men like Dr. Philo R. Hoy of Racine. It performed invaluable service to the state in the way of popularizing a love of fruits and flowers. It was said that the severe winter of 1856-57 almost totally destroyed the orchards grown prior to that date; but, nothing daunted, the society urged replanting and the planting of new orchards about all homes which were unsupplied. 
The majority of the farmers in southern Wisconsin, however, turned their attention to livestock as the surest means of making a profit. There was little uniformity either in kind or in type of animals, and one might have seen a herd of grade Durham steers in one man's pasture, a herd of common cows in that of the neighbor adjoining, horses in a third, and sheep in a fourth-depending on which the owners thought would pay best. A fifth farm might show few cattle, horses, or sheep, but its yards and clover fields would be overrun with hogs and pigs of all sizes and conditions.

Perhaps the closest parallel to or nearest successor of the former extensive wheat grower as a man of business was the farmer who fattened cattle on a considerable scale. Such men were to be found in all the corn growing counties. They raised big fields of corn in place of the former fields of wheat, bought up stock cattle through the countryside from farmers having a few head each, fed out their corn and, when the cattle were fat, either shipped to Chicago themselves or sold to big dealers. The business called for a good deal of capital, which only a few could command, good judgment in selecting animals, and shrewd bargaining both in buying and in selling. Some farmers succeeded where others failed, and the successful cattle feeders rose to be almost a distinct class. They had business and social relations with other cattle men, as well as with the numerous farmers from whom they bought, with bankers, and with city commission merchants. In addition, some of them were money lenders and held the mortgages on much farm property in their neighborhoods. This gave them power but not unmixed popularity. Thus the cattle feeding farmer enjoyed some of the opportunities and advantages which came to the western ranchman. But, unlike the ranchman, who was free, venturesome, untired, he often took his full share of the hard, plodding labor of field and barnyard, remaining what the other would be apt to call "a hayseed farmer.",3

\footnotetext{
- Cattle feeding as an alternative to dairying is still a business of considerable importance in certain sections of the state, notably the southwestern counties.
} 
Corresponding to the variety of farm activities was a kaleidoscopic diversity in farms and farm buildings. Fields were still enclosed, for the most part, fences being of boards, or boards and wire, of barbed-wire alone, of poles, and of the old "worm fence" type, which, however, was disappearing in the older districts. Buildings for housing the livestock were of every description, from the permanent hillside barn, well protected above the stone work by means of a coat of red paint, or the all frame type, built wholly above ground, with hayloft on the second floor, to the pioneer's frame of poles covered with straw. Cows were not generally stabled for milking but were milked in the "cow yard." "Next to the diversity due to different types of farming was the picturesqueness imported into the rural neighborhoods through the mingling together of several distinct racial stocks. Although the southeastern counties were originally occupied almost exclusively by people from the Northeast and from Ohio, it was not long before many foreigners, especially Scandinavians, Germans, Irish, and Welsh, were distributed among them. The Town Studies of the Wisconsin Domesday Book illustrate the point, showing how Mount Pleasant, for example, came to have one-third of its people of foreign birth, Whitewater onefourth, and so on. Proportions like these left the general character of the community American, but the infusion of foreign blood showed in several ways. While many immigrants came with money and bought good farms at once, some at first were poor. Such people lived in the log houses abandoned by the older farmers, or built new log or cheap frame houses on small tracts purchased to make the beginnings of their farms. Some of their children might be "hired out" to nearby farmers, the boys as field help, the girls as housemaids. Meantime, their farms were started, and with hard work and thrift they were often enlarged until the labor of all the family was required properly to work them.

- Hamlin Garland's memory of the cow yard, as presented both in his short stories and in $A$ Son of the Middle Border, is perhaps typical of the sense of loathing generated in sensitive minds by that institution. 
Every foreign element had its own peculiar customs both inside the home and outside. In cookery they introduced new dishes, in gardening new plants and new varieties of flowers. Germans, Scandinavians, Bohemians, and others were wedded to gardening as a feature of home making. Some Americans also were excellent gardeners, but many of them were content to raise a few things only, like early potatoes, some cabbages and melons. With the foreigners gardening was a household art. The women and younger children performed the labor, and the garden-a small plot of ground next the house, highly fertilized, cultivated intensively, fenced against poultry by means of either pickets or woven willows-was apt to be a charming little world with its plats separated by lily bordered paths growing scores of different esculents, its currant and gooseberry bushes lining the fence, and its clusters of decorative flowers, shrubs, and vines. Perhaps there was also a "summer house" of lattice work covered with morning-glory. Though the houses of immigrants might be inferior to those of their American neighbors, their gardens, which guests were always glad to visit, compensated them in large measure.

On their first little farms the foreigners frequently used oxen when horses were the rule among all other farmers. This made an interesting variation, both in the fields and on the highways. The foreign costumes, mode of speech, and social practises all differed at first from the American, but tended rapidly to grow less distinctive. The children in the schools were the quickest to assimilate American speech and customs, the women in the homes the last. But where immigrants of the same race lived in colonies, as in the northern lake shore counties and a few other sections, these changes proceeded much more slowly. There many old-world customs descended even to the grandchildren.

A significant fact in connection with earlier foreign immigrants to Wisconsin was the almost universal training of the adult in some line of useful endeavor. Among those who had not been farmers at home nearly all had some trade or craft, learned by apprenticeship. There were carpenters, 


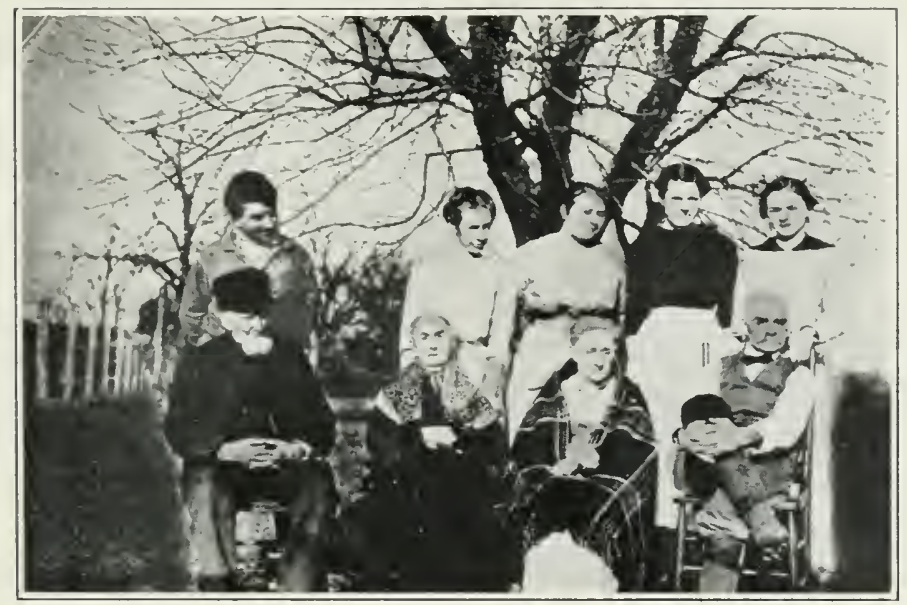

A WALWORTH COUNTY FAMILY

Grandparents emigrated from New England, children and grandchildren born in Wisconsin

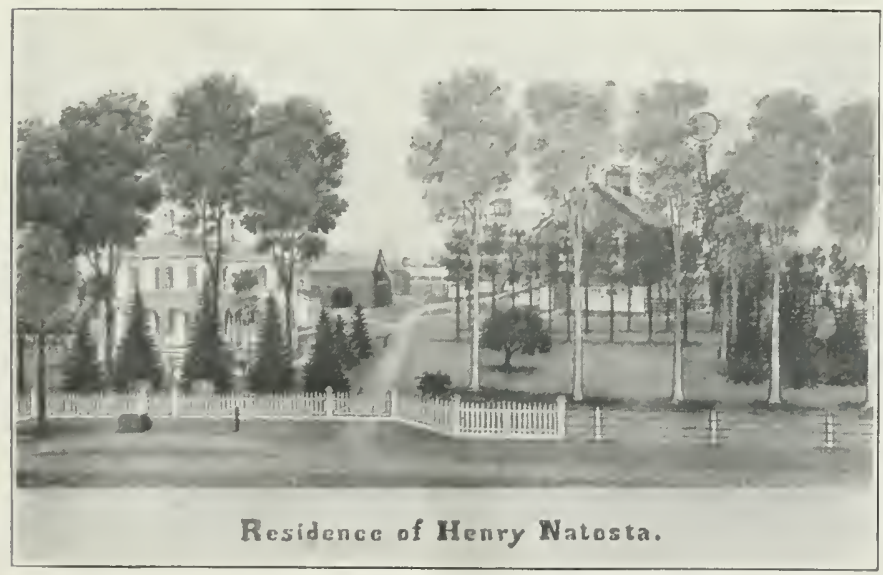

RESIDFNCE OF HEXIR NATESTA, BERGEX, ROCK PRAIRIE Modern phase of a Norwegian farm lome 


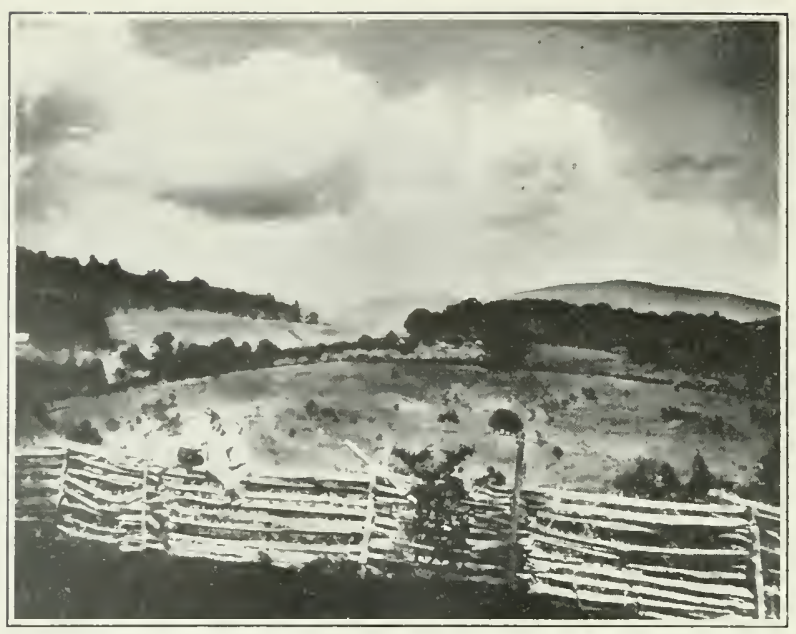

TIE DISAPPEARIXG R.IIT, OI VIRGTIA "WORA" FEICE

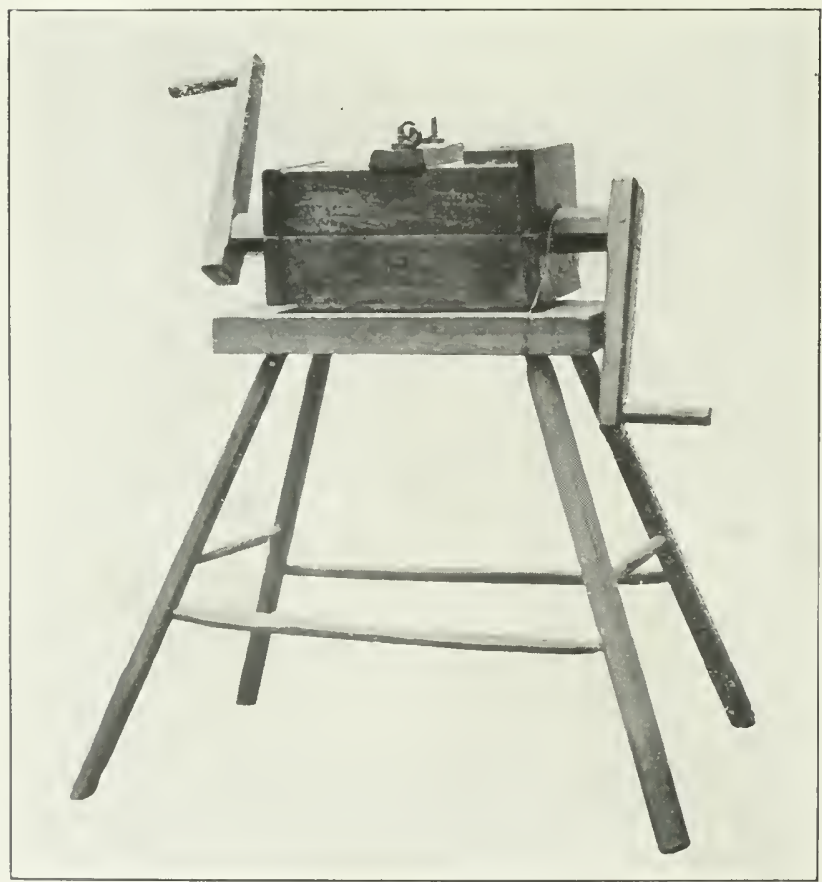

SAUSAGE GRINDER MADE BY A GEIRIAN IMMIGRANT Original in the State Historical Museum 
cabinet makers, turners, plasterers, masons, painters, weavers, spinners, metal workers, book binders, musicians, millwrights, and wheel-wrights. Occasionally, to the amusement of acclimatized immigrants, someone would appear who was equipped with a trade which, though very usable in the old country, had no market value here-for example, a tiler, or roof slater. Often enough these callings had little relation to the business of farming, yet nearly always the special skill showed somewhere in the arrangements of farm or home, and often it became invaluable to the neighborhood. If nothing more, the presence of men possessing such special gifts produced a healthful wonderment in the young. The foreign craftsmen who actually functioned-for example, wood workers and iron workers-were better trained than the Americans in the same lines, just as foreign trained farmers were closer, more careful cultivators. Consequently, their skill fixed the standards for the communities. Many a fine, though unpretentious, farmhouse enjoys distinction today as a relic of the pioneer period because some clever foreign trained carpenter, brick layer, or mason was given a free hand in its construc: tion and played architect as well as builder. Hundreds of pieces of farmhouse furniture and bric-a-brac owe their existence to the same source of artistic skill and good workmanship. Since everyone who had the opportunity to do so, nat: urally tried to reproduce the types of buildings and furniture with which he was familiar in the old country, some degree of variety was introduced by them into the environments of Wisconsin farm neighborhoods.

If we were to extend this discussion to conduct and intellectual influences, one might say that the elaborate, formal cour: tesy displayed by well-bred foreign immigrants often left its impress upon sensitive youth, while the new horizons touched by their conversation about European politics, military history, and social life excited the imagination of many an' American boy and girl. Even the superstitious folk tales of ghosts and giants related to children by foreign domestics and by hired men supplied a tinge of poetic color to lives which 
were all too completely immersed in existing realities. Their songs and instrumental music, so different from the prevailing church music and the sentimental love songs of the Americans, made another favorable contrast. On the other hand, the tendency among many foreigners to make excessive beer drinking a feature of their amusements created a very unfavorable impression upon the more rigid church-going temperance people, and reinforced their determination to do away with the liquor saloon by means of legal restrictions.

There was much individuality in the way farmers, both Americans and foreigners, performed their farm work. To be sure, as in any other business, some men were industrious and clever workers, others were sluggish, careless, or lazy. But, in addition to that universal difference the good workers had methods of their own. One would depend more on hand work, like hoeing corn instead of cultivating with the use of horses, or cradling his small fields of grain instead of using the reaper. Another, more business-like, would use horse power for everything. In general, the Americans were apt to be horse farmers, the foreigners hand farmers; but there were many exceptions. Some would rise at an unconscionable hour, say half past three, and work until after dark; others followed the good old rule and labored in the field "from sun to sun." If the hired men on Wisconsin farms had been diarists, one would obtain pictures of interesting farmer personalities as seen by their underlings. Every neighborhood had its hard drivers, who so overworked their men that it became difficult for them to secure hands.

After the introduction of factory dairying, it was almost the universal practise to begin field work late in the morning and close early in the evening, say at half past five. But in the earlier period, the occasional farmer (usually an American) who followed that practise was looked upon by his neighbors as "lazy and shiftless," notwithstanding the appearance of his crops, livestock, home, and barnyard belied such a conclusion. The greatest divergence prevailed with respect to work on Sunday. Religious people generally kept Sunday 
free from all work save the "chores." Some of them, however, made rather free use of the biblical permission to drag one's ass or ox out of a pit on the Sabbath day. The trouble was that they were not at all literal in defining ox or ass, or in defining pit. The words covered any emergency job, and the habit, once formed, of doing exceptional jobs on Sunday, such jobs easily became numerous enough to occupy the farmer practically every Sunday in summer. And in those days, when the farmer worked on Sunday his men usuaily worked, his children worked, and of course his teams worked. The effect was a loss of morale all around. Those farmers, whether churchgoers or not-and many non-churchgoers were in that class-who rigorously kept Sunday as a day of rest for man and beast, encouraging the hired men to spend it well, in a restful way, giving the work animals a few hours of much relished freedom and smiling on the children's play, were supporters of a far wholesomer type of rural life.

Religiously, those communities appear to have been most prosperous whose people were mainly of the same speech and same social condition even if they varied somewhat in religious beliefs. Some of the American communities worshiped very harmoniously in that Protestant church which suited the majority sect, whether Presbyterian, Methodist, or some other. And the same was true of Germans, Scandinavians, and English or Welsh. Old Lutheran and Reformed did not always have separate churches, though when each sect was numerous they commonly did. Unity in other matters made unity in religion easier to achieve. Some churches, however, which were homogeneous doctrinally were divided racially and manifested much disharmony.

The organizers of churches, both Catholics and Protestants, were often men of powerful personality who were able to contribute largely to the building up of rural life on its spiritual and intellectual sides. Yet it is doubtful if their work as institution builders was always beneficial. Overzeal in the interest of the denominations they represented induced them frequently to start a second organization where one already ex- 
isted, or a third within a township having two others, thus weakening the support of all and making it impossible finally for the rural churches to maintain themselves against the rivalry of town and village. Many an abandoned wayside church stands as an accusing witness to such mistaken missionary effort. It is also true that changes in rural life, the shifting of the population, the emigration of some of the original families, the influx of new families of a different faith, and particularly improvements in locomotion-better roads, lighter vehicles, speedier roadsters, the auto-all have helped to rob the rural communities of many once flourishing churches.

The old-time camp meeting, a distinctively rural phenomenon, entered Wisconsin soon after its settlement from the East. In August, 1838, there was held such a meeting in the grove along Root River near Racine, which is said to have been attended by hundreds of pioneer families from all the southeastern counties. It was the first one held in that section, if not the first in the state. The appointments were identical with those described by Eggleston and other writers on religious conditions in the West. For example, the grounds at night were lighted in the regulation camp meeting fashion, by means of great fires built on elevated stages floored with poles and covered with earth. ${ }^{5}$ Such meetings continued to be held periodically in some communities until less than forty years ago. They have for the most part given place to the "tabernacle" revival meetings, now always centered in the towns.

The intensity, or drive, which the farmer put into the work on the farm affected the children most directly. To the man who was intent merely upon getting more and more acres cultivated though it required night and Sunday work to do it, the time of his children was chiefly valuable for the amount of help they could give him. Their schooling was entirely secondary, their recreational needs not even considered. Play was opposed to work. The boy who loved to play was apt to

\footnotetext{
- See Racine Argus, Aug. 15, 1838, for a full deseription of the meeting.
} 
be stigmatized as "too lazy to work," and a similar judgment often fell with crushing weight on the boy or girl who was more than ordinarily fond of books and reading. The probahility is that about the same proportion of farm children were gifted in those days as at present, yet statistics of high school, academy, normal school, and college prove that the number who actually secured an opportunity for full intellectual development was exceedingly small in comparison with the numbers who have that opportunity today. The reason is to be sought partly in the earlier deficiency of schools and the obstacles which an inflexible course of study placed in the paths of would-be scholars. But mainly it is to be found in the family's hardship involved in losing a boy's time from the farm labor and in finding the means of meeting inescapable expenses. Very few farmers, comparatively, could afford both the loss of a boy's time and the school expenses, so that if a boy really cared greatly to pursue learning he might reckon on a program which would entail sacrifice. For example, he would be obliged to work for his board, or else take time to earn money between the years or even the terms of schooling. Not infrequently the process was so long and so laborious that graduation found the candidate a mature man of thirty, with plenty of experience behind him to establish a firm, selfreliant character. "Getting an education," as the story of John Muir proves, was an heroic enterprise which remorselessly tested the ambition and moral stability of boys as well as their intellectual powers. ${ }^{8}$

Despite its barrenness in many respects, the neighborhood district school was far more apt to be the inspirer of boys and girls than was the home, the church, or other social influence to which the young were exposed. With all its shortcomings the school was the one avowed "literary institution" of the countryside. Many of the rural school teachers in our period were men of considerable attainments, sometimes

- John Muir, The Story of My Boyhood and Pouth (Boston, 1913), contains the story of a Wisconsin farm boy's struggle to obtain an education. 
boasting college degrees. Frequently they were graduates of some eastern academy or normal school. They taught rural schools in order to gain a teaching apprenticeship before taking higher teaching positions, or as a stepping stone to one of the other learned professions, or to a business career. A few were farmers in the summer and teachers in the winter. Every neighborhood has its tradition of noted teachers of this type who left a lasting impression upon the community.

It was these men, in large part, who were responsible for the steady trickle of students into the schools of higher learning from country neighborhoods. Sometimes the direct word of advice or encouragement fired a boy's mind; more often perhaps it was the opportunity for self-testing furnished by the class competitions, literary and declamatory contests, and debates. For the live rural teacher stirred his pupils by arousing the whole community to an interest in what the school was doing, and by making the schoolhouse a social center in addition to a focus of intellectual activity. He arranged spelling matches which drew in the best spellers from adjoining districts to compete with his scholars, his school exhibitions brought in most of the people of the district, and the debates, notwithstanding the strongly theoretical subjects commonly chosen, occasionally attracted wide attention through the county. ${ }^{7}$

School entertainments by no means exhausted the social and recreational facilities of farm neighborhoods, although they constituted a very important part of them. The "singing school," also conducted at the schoolhouse, was a valid excuse for the assembling of boys and girls; and when the peripatetic singing master, as sometimes happened, was both a good instructor and a strong personality, the cultural influence of the

"A Racine County school (No. 3) in 1868 debated the question "Shall the United States acquire the island of Cuba?" The liquor question, woman's suffrage, capital punishment were all favorite subjects for school literary society debates. 


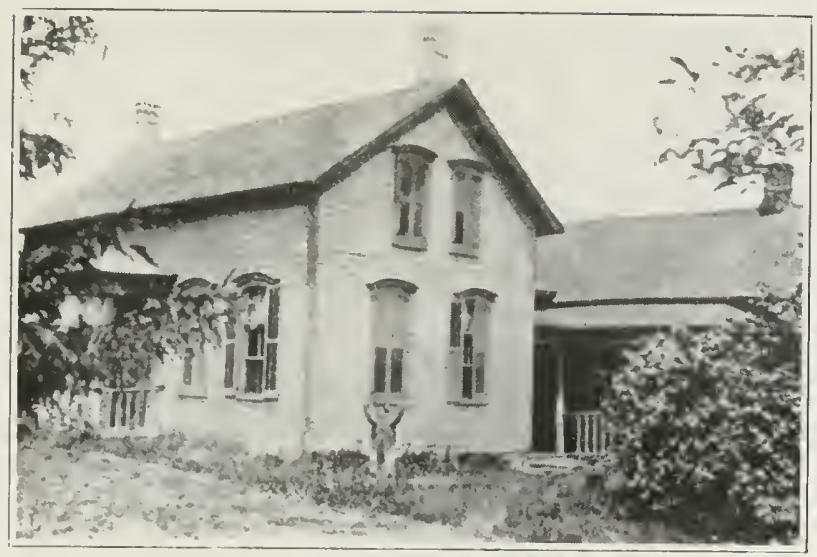

THE MEYER FARM

Ifome of Balthaser Hemry Meyer Juring his student days at Oshkosh State Normal and Tniversity of Wisconsin

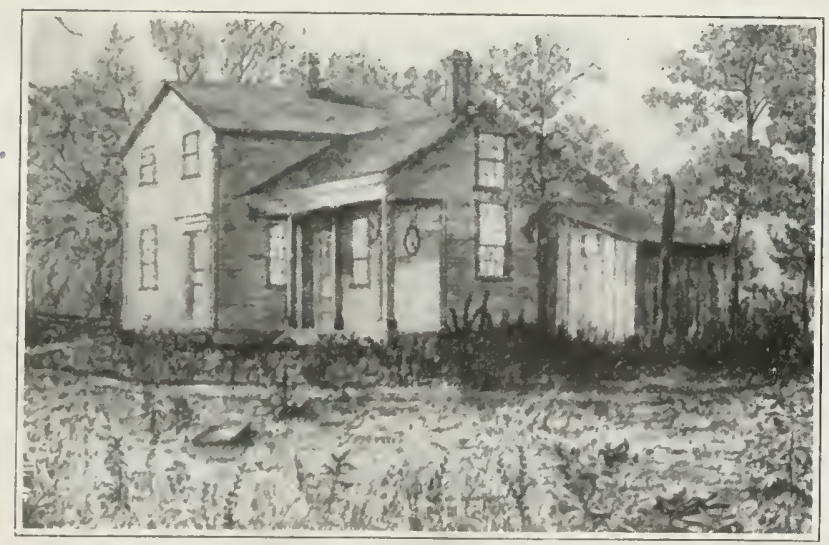

HIOKORY HILL FAIR HOME OF JOHN TLUR DURING IIS STUDENT DAYS AT TIE UNIVERSITY OF WISCONSIN

From his Story of My Boylond and Youth. By courtesy of the Houghton Mifflin Company 


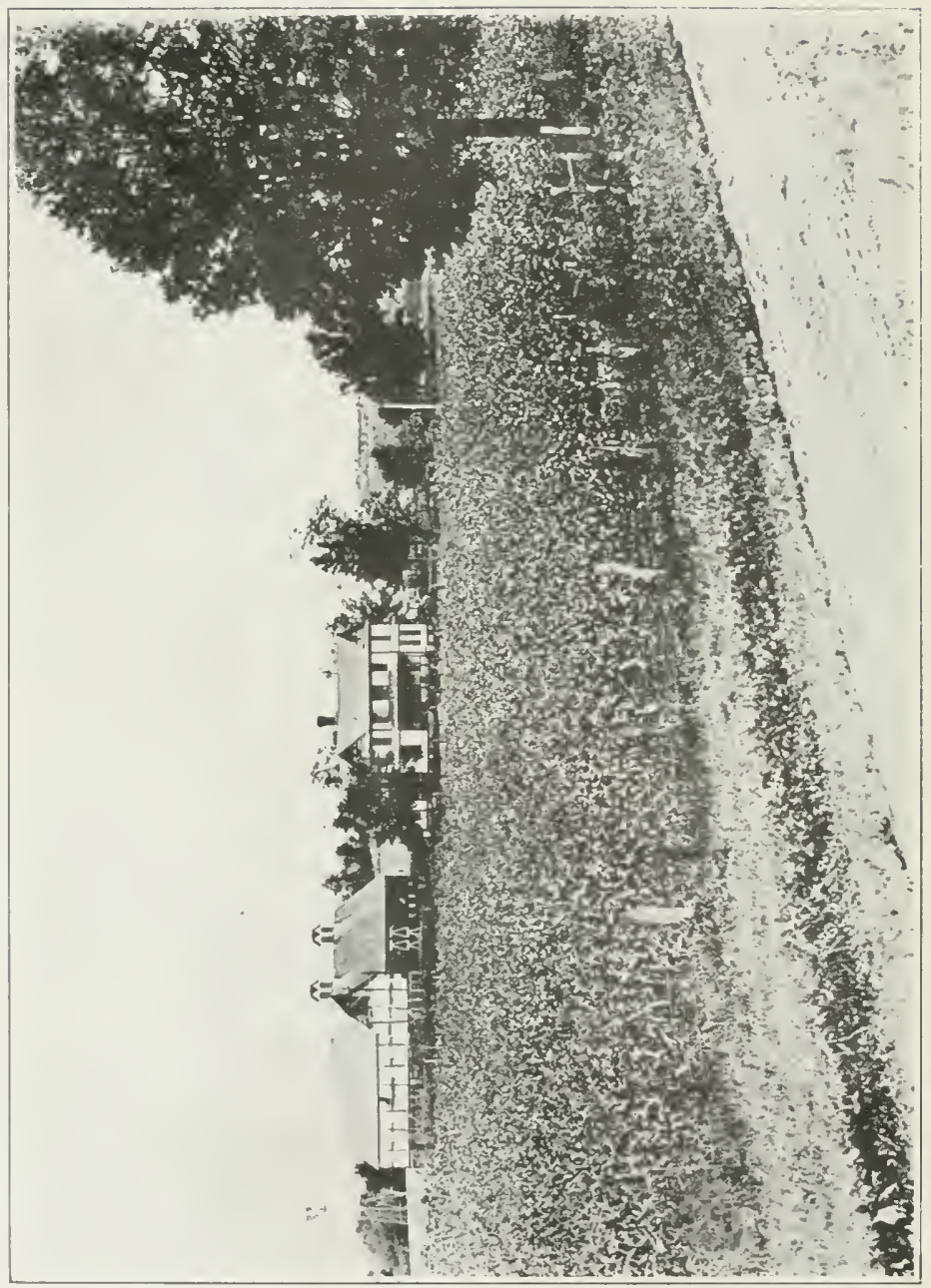

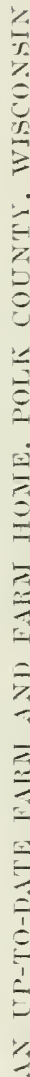


meetings was not inconsiderable. ${ }^{8}$ Their occasional concerts drew a more than local audience.

About the year 1880 or 1881 (at least in southwestern Wisconsin) farm boys began to organize baseball clubs modeled after those already familiar in the towns. Having no Saturday afternoon holiday, the practise meets and games were placed on Sunday afternoon. They attracted all of the young folks, a good many of the elders, and of course the farm hands. The result was wholesome in several ways. Though the games cost the players doubly sore muscles for a day or two during each week, and occasionally a broken finger, these gatherings put the cumulative force of social coöperation behind the unuttered demand of children for a recognition of the right to play. Incidentally, they went far to abolish Sunday work on farms and, by a natural reaction on the part of the church people, led in many places to the custom of a Saturday half-holiday.

All the world knows about the country ball or "dance" of forty or fifty years ago, where dances were mostly quadrilles, the music "fiddling," and the movements of the dancers guided less by art than by what, in terse country phrase, has been called "main strength and awkwardness." This signifies that the dancers' reactions to the rhythm of the music and the directions of the prompter were dictated by natural impulses gradually modified by experience, observation, and self-criticism; not that they were necessarily devoid of grace and harmony. Boys and girls learned to dance by dancing in public as participants in a four-couple quadrille, with no preliminary private lessons to familiarize them with the motions, the changes, or the etiquette to be observed toward partners and others. To many an awkward youth the "first dance" was his social "baptism with fire," but those who possessed the right qualities were molded thereby with surprising

\footnotetext{
- The state had some noted singing masters, like Luther Lyman of Whitewater, who maintained the same itinerary year after year for perhaps fifteen years, training an entire generation. Some of the singing masters were foreigners of excellent preparation. W. D. Hoard also was a singing school master for several years.
} 
promptness into well poised, courteous, gentlemanly fellows.

From the standpoint of social training, the country dance performed a service of obvious value. Unfortunately, in many neighborhoods dancing tended to become too exclusive a form of recreation, thus depriving young people of other forms which were more educational or more healthful. Worst of all, balls of a public character were generally commercialized and they often came under the baleful influence of the saloon, of reckless drinkers, and of the rowdy element. On moral grounds some religious denominations opposed dancing, and every community was likely to have a pro-dancing party challenged by a no-dancing party, which sometimes gave rise to bitter contests over questions of social policy. ${ }^{9}$ Perhaps no one thing did more to impair the social unity of neighborhoods, and to paralyze plans for providing wholesome recreation, than the eternal question of dancing or no dancing.

Many farmers made "going to town" more or less a weekly holiday, taking Saturday for that purpose quite as regularly as the women took Monday for wash-day. The Saturday trade was a kind of "clearance sale" for the village storekeepers, although prices were not marked down and little cash changed hands. The farmers brought in whatever they had to sell, especially butter and eggs, whose value would be checked off against the purchases and the balance charged or -more rarely_credited. But buying and selling was only the incentive of these weekly trips, not the exclusive motive. Farmers who had the habit would make an excuse to go to town even if there was no business justification for it. They felt the need of the customary relaxation, of dressing up, of the opportunity for conversation, for learning the news of the wider neighborhood, and for "seeing what was going on." Those who developed the saloon habit and wasted their time and money carousing are not considered in the above description.

- See the report of an excoriating sermon on dancing, in Stirling W. Brown, In the Jimestone Valley (1900), 168-172. 
The village merchant is not often credited with a social function, yet his store was a genuine social center. Perhaps for the older people it was the most important single social opportunity aside from the church, and its value for that purpose varied with the character of the storekeeper. In some cases he was an original and striking personage, men of inferior personality being apt quickly to fail. Dealing with a group of families which remained relatively constant, he gradually acquired much detailed knowledge of their affairs and could instantly speak the name of practically every man and woman of the countryside. He would see to it that the persons assembled in the store became acquainted with one another. He was always able to start the conversation with a pertinent question directed to this one, a comment uttered here, a remark countered there. The store of such a man was always on Saturday a buzzing reception hall with people coming and going, with groups of men and women constantly joined in the most spontaneous because unconscious and incidental social intercourse. ${ }^{10}$

The children and young people received less benefit from the town going habit than the elders, because their trips to town were less frequent and not at all regular. They went in force only on special occasions, such as Fourth of July, circus day, and fair time. ${ }^{11}$

It will be understood that the farm life above described was that of the open country, away from centers of population. Some farming communities were situated in the immediate neighborhoods of cities, towns, or prosperous villages, and their families participated in many of the social opportunities enjoyed by the urban people. They took advantage of the

${ }^{10}$ See Grant Showerman, A Country Chronicle (New York, 1916). He gives a marvellously lifelike picture of the evening conference at the store (in Brookfield, Waukesha County) about 1880. He depicts the types of farm work, including sugar making, and also gives dramatic deseriptions of the country ball and other rural amusements.

1s But it was a kind of vacation to them to have the parents away once a week. Work was less strenuous at such times, supervision was lax, and the spirit of fun rampant. Then, too, it was exciting to speculate about what the parents would bring home on their return. 
church services, the school, the library, the theatre, the recreational facilities, and the varied means of keeping in touch with the outside world which were denied to dwellers in the open country. Such families, so long as they prospered economically, had no serious social problems to meet. For they might live as well as the prosperous families in town and mingle socially with such families. But any falling-off in income meant a corresponding decline in status. Expenses being higher near the city than farther out, general farmers often failed to make ends meet. These farmers accordingly sold out to others ${ }^{12}$-largely foreigners-who lived more simply, adopted more intensive methods, raised more produce, and made the farms pay. Herein we find part of the explanation for the prevailingly foreign cast of the suburbanite farming population. Another is the fact that so many of the later foreign immigrants came from cities, where they were habituated to the delights of a well developed social life which they were unwilling to exchange for the compensations afforded by a home in the open country. They understood how to get the most out of a few acres of land, were accustomed to land values much in excess of those encountered in Wisconsin; some of them came well supplied with money to buy, and others were willing to mortgage the future, for many years, in order to obtain present enjoyment of a farm close in. A glance at successive series of land ownership charts of townships adjacent to the lake cities will show how, little by little, English names disappeared to be replaced by those of German, Dutch, Scandinavian, Bohemian, and Polish origins. A town like Sheboygan Falls, once occupied largely by farmers from New York, is now held in smaller tracts and farmed more intensively by farmers who are mainly Germans.

The process of rural development, coupled with the extraordinary growth of towns, has already brought about a vast

\footnotetext{
12 The writer has personal knowledge of communities in the Dakotas whose families, now owning from 160 to 640 acres of land each and ranking as prominent, prosperous citizens, were emigrants about 1880 from undesirable farms in the hill country of southwestern Wisconsin.
} 
increase in the suburbanite class of farmers. In effect also the motor car and good roads make it possible for those living not more than eight or ten miles from town or city to do their weekly shopping on Saturday night, after chores, as easily as formerly they could do it by taking the entire day. And it becomes equally practicable for them to enjoy the church, the theatre, lectures, and entertainments held in the near-by town, while they can visit more distant places with economy and ease. Thus farmers have now a vastly enlarged sphere of action, a larger circle of friends and acquaintances, and a multitude of social opportunities where formerly they had but few.

All this proves beneficial to the rural family provided money is forthcoming to pay for the car and its upkeep, for the good roads, for the better attire of the young people, who now insist on city styles in all personal appointments, for a home with modern conveniences, especially flowing water, bathroom, electric light (or its equivalent), and for such household furniture, musical instruments, books, and magazines as are found in the city homes where the young folks visit and whose members they expect to entertain. In addition, the expense of educating children is greater, high school training being now a customary supplement to the graded school, and a college course, or at least special agricultural and home economics courses, being desired by a large proportion. Thus the success of farm life on the social side depends on the ability of the farmer to make the farm yield a more generous income than that to which earlier farmers were accustomed.

In the new dairying, farmers have developed a methodology of success which may illustrate also what is possible in other lines. So many of the processes involved have been standardized that, assuming a reasonable or normal market, ${ }^{13}$ results can be predicted with a good deal of accuracy. In the old days making butter to sell was a species of gambling, if only because the farmer had the vaguest ideas as to how much butter

1s This at the moment of writing does not exist, and it creates the most acuto country life problem, demanding statesmanlike handling. 
his cows would produce in the year, what amount and value of food they consumed, or what expenses were incurred in production. Today farmers have the means of determining food costs and labor costs, while the almost universal practise of testing butter fat production of cows gives to the herd an ascertained character and value in production. Moreover, breeding for performance has become, if not a science, at least a very widely understood and successfully practised art. Within uncertain but wide limits it is now known to be practicable to increase production by careful breeding; the farmer has his choice of a large number of recorded herds from which to select breeding stock, he has at his command the scientific advice of successful breeders, of the agricultural college, and of the county agricultural agent. It has been historically demonstrated many times that a herd of cows which averages 200 pounds of butter fat can be improved by breeding and selection among the offspring until in a few years it is a 300 pound herd and soon thereafter a 400-pound herd. With purebreds records much higher than that have been obtained.

It has also been shown that by using silage in summer as well as in winter, and by feeding soiling crops instead of pasturing exclusively, the unit of land per cow can be greatly reduced. Hiram Smith's ideal, as far back at least as thirtyfive years ago, was 100 cows on 100 acres. His land was among the very best Wisconsin farm land for growing forage crops, roots, etc., and he may not have attained his ideal, but he and many others have approximated that standard. Accordingly, the farmer who has a small farm, say 60 or 80 or even 40 acres, can today hope to succeed as a dairyman. In the past he could not do so, and therefore, when dairying became dominant the small farmer sold out to his neighbor and left Wisconsin just as, forty years earlier, his prototype in Vermont and in New York left those states to go to Wisconsin, Iowa, and Illinois. It was the departure from southern Wisconsin communities of so many small farmers that explains the actual reduction of the farm population in those counties at recent census periods. Obviously, the only prac- 
ticable way to increase the rural population is to increase the number of farm families, and that, in a well settled country, means dividing the larger farms into smaller farms. The process of division has begun, and it constitutes the chief basis of hope that our rural population will be built up in numbers while retaining and improving the economic status already achieved. It is easy to estimate that 20 cows averaging 400 pounds will make more profit for their owner than 40300 pound cows. And if the 20 cows are maintained on 40 acres while the 40 cows required 160 acres, the profits will be further augmented by the saving of three-fourths of the land, which could be supporting other families to help maintain roads, consolidated schools, churches, and rural parks-thus raising farm life to the same plane of success socially that in normal times under the most approved system of farm management it occupies economically. 



\section{APPENDIX}

A CEnsus of OLD HOMEsteads

Edited by EdNa LOUISE J J 



\section{A CENSUS OF OLD HOMESTEADS}

In the December, 1920, issue of the Wisconsin History Bul. letin, the State Historical Society addressed to the public through the newspapers of the state the following invitation and directions:

The State Historical Society wishes to obtain and publish a census of those farms sixty years old or more, which in this year 1920 are still in the families of the men and women who created them out of pieces of wild land. It matters not from whom the title originally came-whether the United States government, the state government, or a private owner. The only condition is that the land must have been improved or made into a farm by the present owner or one of his or her ancestors.

Owners of such family homesteads are requested to send in the requisito information about them without delay. For convenience in filing, the following form should be used:

1. Description of land [Example: NE/4 SE/4 Sec. 7. T. No. 8 R.2W].

2. Maker of the farm [Example: James W. Jones].

3. Date at which ownership began [Example: 1842].

4. Origin of title [Example: From U. S. Govt. Cert. of Purchase No. 5763; From State. Cert. of Purchase No. 7321; From John Smith. Warranty deed, 1842].

5. Date of his settlement on the land [Example: 1843].

6. Proof of above statement as to date of settlement [Example: A letter written by the settler or some member of his family; some instrument or transaction which is of record; statement by original owner later in life; testimony of aged neighbors knowing the facts].

7. Name of present owner and relationship to original farmer [Example: Wesley G. Jones, grandson of James W. Jones].

- 8. If possible give a brief sketch of the original farmer, a photograph of him, and any photographs of the farm, with approximate dates.

9. Description of the present farm.

10. Date of report.

Kindly send information to State Historical Society of Wisconsin, Madison, Wisconsin.

The response was immediate and for a time encouraging. A considerable amount of data drifted in during the succeeding three or four months, after which there was a lull and then a complete cessation of letters about ancestral farms. In August, 1922, the invitation was repeated and a new group of entries came in for record. 
In preparing this first list for publication as an appendix to the History of Agriculture in Wisconsin, Miss Jacobson has selected from the data now in hand the most typical cases, distributed somewhat evenly among the counties represented. Others will appear, in groups, from time to time.

The State Historical Society of Wisconsin offers the opportunity to owners of such farms to make a permanent record, but it does not feel called upon to canvass the state for data. What we receive from persons interested will be recorded in due time and in such form as seems advisable.

\section{JosepH Schafer.}

\section{BROWN COUNTY}

Charles Williams Homestead. (1) Description of the land: Lot 105 of subdivision of tract of land known as the "Williams Grant." (2) Maker of farm: Charles Williams, native of England. (3) Origin of title: Warranty deed, 1860. (4) Date of settlement on the land: 1861. (5) Present owner: Mrs. M. A. Bidwell, daughter of Charles Williams. (6) Date of report: December 27, 1920.

When Charles Williams left England in 1850, he came first to Canada, and in 1858 to Green Bay. The farm which he developed is situated on a state trunk highway about five miles from De Pere. During the first winter $\mathrm{Mr}$. Williams earned a living cutting wood and hauling it with oxen over the trail which has since been converted into this modern concrete road.

Mrs. M. A. Bidweld, West De Pere.

\section{CRAWFORD COUNTY}

Michael Ward Homestead. (1) Description of the land: S $1 / 2$ NE $1 / 4$ and SE $1 / 4$ SE $1 / 4$ Sec. 20, SW 1/4 SW 1/4 Sec. 21, all in T 11 N, R 3W, Town of Clayton. (2) Maker of the farm: Michael Ward, born 1812, in County Galway, Ireland. (3) Origin of title: U. S. Govt. patents, 1854 . (4) Date of settlement on the land: 1858. (5) Present owner: W. M. Ward, grandson of Michael Ward. (6) Date of report: Jan. 19, 1921.

Michael Ward and his family came to Wisconsin from Dixon, Illinois, making the trip in the fall of 1858 with two yoke of oxen. They made a shelter of their carts and used them for houses until spring. The land comprising this homestead contains many fine springs.

W. M. W ARD, Soldiers Grove.

\section{DANE COUNTY}

Henry Boning Homestead. (1) Description of the land: N $1 / 2 \mathrm{SW}$ $1 / 4$, SE $1 / 4$ SW $1 / 4$, W $1 / 4$ NE $1 / 4$ SE $1 / 4$ Sec. 2, T 5 N, R 8E, Town of Montrose. (2) Maker of farm: Henry Boning, native of village of Goldenstead, Oldenburg, Germany. (3) Origin of title: Warranty deed from Sebastian Waffle and wife, 1855. (4) Date of settlement on the land: 1855. 
(5) Present owner: Henry Boning, aged 93 years. (6) Date of report: Dec. $13,1920$.

On his first trip to America, in 1843, Mr. Boning settled in Cincinnati. In 1850 he joined the California gold seekers, making the trip by way of Cape Horn. On his return he visited his native land, after a few years immigrating to Wisconsin and settling on the farm he now owns. He cleared and broke the land, erected all the farm buildings, and set out many ornamental trees.

Helen Boning, Basco.

Sylvester Carpenter Homestead. (1) Description of the land: SE $1 / 4$ SW 1/4, W 22 A. NW 1/4 SW 1/4, and SW 1/4 SW 1/4, all in Sec. 27, District No. 7. (2) Maker of farm: Sylvester Carpenter, native of New York. (3) Origin of title: U. S. Govt. patent, 1846. (4) Date of settlement on the land: 1846. (5) Present owner: Orlow Carpenter. (6) Date of report: Feb. 9, 1921.

Sylvester Carpenter and his wife had for their first Wisconsin home a eomfortable house of sawed lumber hauled from Milwaukee; this house is now used as a granary. Across the land lay a well worn Indian trail from Lake Koshkonong to the Madison lakes. The farm yielded in 1848 mainly wheat, gradually changing until now it is one of the finest tobacco farms in Dane County.

MARY HART, Oconomowoc.

David Chichester Homestead. (1) Description of the land: E $1 / 2 \mathrm{SE}$ $1 / 4$ Sec. 22 and W side $W_{1 / 4}$ SW $1 / 4$ Sec. 23, all in T $5 N, R 11 E$, Town of Dunkirk. (2) Maker of farm: David Chichester. (3) Origin of title: Purchase from Joseph Owens, 1849. (4) Date of settlement on the land: 1849. (5) Present owner: Herman Chichester, son of David Chichester. (6) Date of report: January, 1921.

The first house erected on the Chichester homestead was of logs; though small, it housed fourteen men who were working on the Chicago, Milwaukee, and St. Paul Railroad, which passed close to the farm. The log house was displaced in 1856 by a frame structure. The nearest market was Milwaukee, and to this place Mr. Chichester would haul his wheat by ox team and sell it for twenty-five or thirty cents a bushel. Mrs. C. E. Anthony.

Youngs HaLlock Homestead. (1) Description of the land: E $1 / 2$ NE $1 / 4$ and NW $1 / 4$ NE $1 / 4$ Sec. 35, T $7 \mathrm{~N}, \mathrm{R} 8 \mathrm{E}$, Town of Middleton. (2) Maker of farm: Youngs Hallock, native of town of Minisink, Orange County, New York. (3) Origin of title: U. S. Govt. patent, 1847. (4) Date of settlement on the land: 1851. (5) Present owner: Hulett Hallock, son of Youngs Hallock. (6) Date of report: Mar. 11, 1921.

In 1847 Youngs Hallock eame to Wisconsin, and made his headquarters at Janesville while he and one John V. Cairns made land-seeking trips. His selection was not entirely a matter of choice, as much of the finest land could be bought only at a high price from speculators and Mr. Hallock's means were rather limited. The original house and barn were of oak framework. These with additions are still in use.

Mary J. Hallock, Madison.

Rudolph McChesney Homestead. (1) Description of the land: SW $1 / 4$ Sec. 19, T 9N, R 9E, Town of Vienna. (2) Maker of farm: Rudolph McChesney. (3) Origin of title: Purchase from Asa G. Ransom, 1855. 
(4) Date of settlement on the land: 1856. (5) Present owner: Joseph B. MeChesney, son of Rudolph McChesney. (6) Date of report: Feb. 5, 1921. The old trail from Madison to Baraboo, used in early days, was within a fer rods of the house.

Joseph B. McChesney, Dane.

\section{DODGE COUNTY}

John Becker Homestead. (1) Description of the land: E $1 / 2 \mathrm{~N} 1 / 4$ Sec. 33, T $11 \mathrm{~N}, \mathrm{R} 17 \mathrm{E}$, Town of Herman. (2) Maker of farm: John Becker. (3) Origin of title: Purchase from John Burger, 1859. (4) Date of settlenent on the land: 1859. (5) Present owner: Peter Becker, son of John Becker. (6) Date of report: Feb. 4, 1921.

In 1859 the Becker farm consisted of eighty acres, high and low land, which contained heavy timber and stones. Now the entire tract, with the exception of five acres reserved for pasture, is under cultivation, the low land tiled. The stones have been used in the making of a fence along the entire width of the farm.

Peter Becker, Rubicon.

Nils Erickson Homestead. (1) Description of the land: Lot 5 and $\mathrm{N}$ part lot 6, Sec. 25; E part NW 1/4 NW 1/4. Sec. 25, all in T $9 \mathrm{~N}, \mathrm{R} 16 \mathrm{E}$, Town of Lebanon. (2) Maker of farm: Nils Erickson, native of Hittesdal, Norway. (3) Origin of title: U. S. Govt. patent, 1844. (4) Date of settlement on the land: April, 1845. (5) Present owner: Erick Erickson, son of Nils Erickson. (6) Date of report: Jan. 18, 1921.

Mr. Erickson's first Wisconsin home was at Pine Lake, near Nashotah, where he remained for three years; he then removed to Dodge County, to a farm consisting of rolling land with clay soil, on the west bank of Rock River.

ERICK ERICKSON, Ixonia.

JoHn Jones Homestead. (1) Description of the land: E $1 / 2$ SW $1 / 4$ Sec. 9, T 9N, R 15E; N 70 A. W $3 / 4$ SE $1 / 4$ Sec. 9, T 9N, R 15E; E $1 / 2$ NW $1 / 4$ Sec. 18, T 9N, R 15E, Town of Emmet. (2) Maker of farm: John Jones. (3) Origin of title: U. S. Govt. patent, 1845. (4) Date of settlement on the land: 1845. (5) Present owner: David Jones, son of John Jones. (6) Date of report: Jan. 19, 1921.

Mr. Jones was looked upon as one of the leading farmers of his community. He took much interest in raising standard-bred horses and shorthorn cattle. DAVID JoNES, Watertown.

\section{DOOR COUNTY}

Robert Laurie Homestead. (1) Description of the land: Lot 3 of Sec. 18, T 28N, R 26E, Town of Sebastopol. (2) Maker of farm: Robert Laurie, native of Scotland. (3) Origin of title: Purchase from Joseph Woodard, 1854. (4) Date of settlement on the land: 1854. (5) Present owner: Christine A. Laurie, daughter of Robert Laurie. (6) Date of report: Feb. 14, 1921.

Robert Laurie was a ship carpenter in Scotland, and plied his trade for a time after coming, in 1852, to Buffalo, New York, whither his brother Alexander had preceded him. In 1853 they left Buffalo in a boat of their own making, to look for timbered land near the water. Robert obtained a soldier's claim in Door County, on the shore of Sturgeon Bay, but did not 
settle on it until the following year. He cleared land and burned lime in the summer time, and in winter worked in the ship yards at Little Sturgeon. Later he developed the stone trade, the Laurie Stone Company being the outcome.

Christine A. Laurie, Sturgeon Bay.

\section{GRANT COUNTY}

David Gardner Homestead. (1) Description of the land: $\mathrm{N} 1 / 2$ SW $1 / 4$ SW 1/4, NW 1/4 SW 1/4, except part in NW corner lying NW of the road; NW $1 / 4$ SE $1 / 4$ SW $1 / 4 ;$ W $1 / 2$ NE $1 / 4$ SW $1 / 4 ;$ W $1 / 2$ NE $1 / 4$ NE $1 / 4$ SW $1 / 4 ;$ SE $1 / 4$ NW $1 / 4$; part of W $1 / 2$ SW $1 / 4$ NW $1 / 4$ lying $E$ of highway passing through same, all in Sec. 21, T $3 \mathrm{~N}, \mathrm{R} 1 \mathrm{~W}$, Town of Platteville. (2) Maker of farm: David Gardner, native of county of Meath, Ireland; born 1818. (3) Origin of title: Purchase from Thomas Hugill and Major John H. Rountree, 1847. (4) Date of settlement on the land: 1842. (5) Present owners: John M. Gardner, Mary E. Gardner, Bee A. Gardner, Celia Gardner-children of David Gardner. (6) Date of report: Dec. 15, 1920.

When David Gardner emigrated to America he settled first at Grand Gulf, Mississippi. In 1836 he eame up the Mississippi River to Ottawa, Illinois, where he remained until 1840, when he came to Platteville. In 1842 he built a double log house with an "upstairs"; a small frame addition was built some years later. The present farm consists of $1322 / 3$ acres, with a flowing well upon it.

D. J. GARDNER, Platteville.

JACOB Hooser, Sr., Honrestead. (1) Description of the land: N 1/2 SW $1 / 4$ and SE $1 / 4$ NW 1/4 Sec. 22, T 3N, R $1 W$, Town of Platteville. (2) Maker of farm: Jacob Hooser, Sr., native of Pennsylvania. (3) Origin of title: ర. S. Govt. patent, 1831. (4) Date of settlement on the land: 1831. (5) Present owner: Sarah B. Young, daughter of Jacob Hooser, Sr. (6) Date of report: Jan. 26, 1921.

At the age of thirteen Jacob Hooser, Sr., came up the Mississippi as assistant cook on one of the first steamboats operating so far north on that river. He settled in Platteville, three years later removing to the farm described above. At the outbreak of the Black Hawk War he took his family to Galena and there enlisted. After the capture of Black Hawk he returned to Platteville, where he lived until his death.

D. J. GARDNER, Platteville.

\section{JEFFERSON COUNTY}

Lorenzo Dow Fargo Homestead. (1) Description of the land: SE 1/4 NE 1/4 Sec. 7, T 7N, R 13E, Town of Lake Mills. (2) Maker of the farm: Lorenzo Dow Fargo, born in 1824, in parish of Chesterfield, Colchester, New London County, Connecticut. (3) Origin of title: U. S. Govt. certificate of purchase, 1846. (4) Date of settlement on land: 1846. (5) Present owners: Mrs. Augusta Fargo Anderson and Mrs. Carrie Fargo Bicknell, daughters of Lorenzo Dow Fargo. (6) Date of report: Sept. 12, 1921.

In 1845 Lorenzo Dow Fargo joined a party bound for Wisconsin Territory, going by boat from Buffalo to Milwaukee. His brother Enoch, who accompanied him, had a new double wagon, and William Curre, also a fellow traveler, had a span of horses. To quote from Lorenzo Fargo's Autobiography: "We joined forces, loaded in carpet bags and started for Lake 
Mills. Milwaukee consisted of cheaply constructed residences, a few pioneer stores and shops. We drove on into the 12-mile forest of beech, maple, basswood, elm, ash and oak. The road pretended to be a highway; but was one stretch of dodging mud holes and trees and constantly repairing the corduroy road. The first night we spent in a little half-way house in Wauwatosa. The second at McVane's double log hotel, where we paid fifty cents apiece for two square meals and lodging. Near Summit corners we had our first sight of a Wisconsin prairie and saw our first prairie chickens. Here was rich soil waiting for the pioneer's big breaking plough to turn the furrows. - Aztalan was a booming town. On the third night, November 8, 1845, we reached Lake Mills and spent that night at the Morgan Bartlett hotel.

"In February, 1846, I bought out Lon Perry's claim and went right to work getting out fencing." Mr. Fargo gradually added to bis farm until it embraced over 500 acres. He was a great lover of nature, and in his last years he "turned his time and strength to reforesting his own woods and by his pen endeavored to arouse the people to a realization of the importance and necessity of planting trees for future generations."

The Lorenzo Dow Fargo Free Public Library of Lake Mills was a gift of Mr. and Mrs. Fargo to the eity. MrS. CARrie Fargo Bicknell, Los Angeles, Cal.

\section{MANITOWOC COUNTY}

George Goldie Homestead. (1) Description of the land: W $1 / 2 \mathrm{NW} 1 / 4$ Sec. 23, ' $19 \mathrm{~N}, \mathrm{R} 23 \mathrm{E}$, Town of Newton. (2) Maker of the farm: George Goldie, native of Connaught, Scotland. (3) Origin of title: Purchase from James T. Goldie, 1851. (4) Date of settlement on the land: 1851. (5) Present owner: George S. Goldie, son of George Goldie. (6) Date of report: June 13, 1921.

George Goldie and his brother James emigrated to America in 1819, coming directly to Wisconsin, where they obtained land. They spent their winters clearing land, and their summers sailing the Great Lakes. In 1853 George Goldie abandoned sailing, built a log house, and devoted himself seriously to making a fine farm out of the wilderness.

\section{George S. Goldie, Timothy.}

John Stangeu Homestead. (1) Deseription of the land: S $1 / 2$ SE $1 / 4$

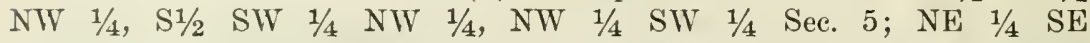
$1 / 4$ and SE $1 / 4$ SE $1 / 4$ See. 6 , all in T $21 \mathrm{~N}, \mathrm{R} 24 \mathrm{E}$, Town of Tiseh Mills. (2) Maker of farm: John Stangel, native of Bohemia. (3) Origin of title: Claims received from the state in 1853, by Joseph Stangel, brother of John Stangel. (4) Date of settlement on the land: 1856. (5) Present owner: Wencel M. Stangel, son of John Stangel. (6) Date of report: July, 1921.

John Stangel and his wife took pride in the fact that they were owners of property, and labored untiringly to clear the land. When the government laid out its public roads, the Stangel homestead lay a quarter of a mile from the highway. $\Lambda$ new site was therefore selected and buildings erected; the original bouse is still on the premises but is no longer used as a home. $\mathbf{M r}$. Stangel took a deep interest in education and religion. The records of the 
school district show that he served as a school officer for several years. The first Catholic church in the locality in which he lived was constructed mainly from lumber which he donated.

Wencel M. Stangel, Tisch Mills.

\section{PIERCE COUNTY}

IsaAC I. Foster Homestead. (1) Description of the land: S $1 / 2$ SW $1 / 4$ Sec. 12, T $27 \mathrm{~N}, \mathrm{R} 19 \mathrm{~W}$, Town of River Falls. (2) Maker of the farm: Isaac I. Foster. (3) Origin of title: U. S. Gort. patent about 1840 . (4) Present owner: Mrs. W. H. Putnam, granddaughter of Isaac I. Foster. (5) Date of report: Jan. 7, 1921.

Isaac I. Foster was at one time county judge of Pierce County.

Mrs. W. H. Putnair, River Falls.

\section{RACINE COUNTY}

Peter Mohrbacher HoMestead. (1) Description of the land: E $1 / 2 \mathrm{NE}$ 1/4 Sec. 13, T 4N, R 22E, Town of Caledonia. (2) Maker of the farm: Peter Mohrbacher. (3) Origin of title: Purchase from John A. Carswell and Horace Norton, 1847. (4) Date of settlement on the land: 1847. (5) Present owner: Adam C. Mohrbacher, son of Peter Mohrbacher. (6) Date of report: Dec. 28, 1920.

The price of the twenty acres of land purchased from Horace Norton was the hauling of a hundred loads of charcoal and barrels that were made on the place. For the rest of the land Mr. Mohrbacher paid $\$ 4.50$ an acre. The original farm buildings are still standing; the present owner has bought land nearer the main highway, upon which modern structures have been erected.

Adail C. Mohrbacher, Racine.

\section{RICHLAND COUNTY}

Williajr Pickering Homestead. (1) Description of the land: NE $1 / 4$ Sec. $8, N_{1 / 2}$ SE $1 / 4$ and $S 1 / 2$ NE $1 / 4$ Sec. 9 , all in $T 9 N, R 1 W$, Town of Eagle. (2) Maker of the farm: William Pickering, born in Lancashire, England, in 1818. (3) Origin of title: U. S. Govt. certificates of purchase, 1850. (4) Date of settlement on the land, 1853. (5) Present owner: Charles R. Pickering, son of William Pickering. (6) Date of report: July $18,1921$.

William Pickering left England in 1848 and eame to Wisconsin for the purpose of owning a home- a goal he could not hope to reach in England. He believed that timber land would remain fertile longer than prairie land, and sought it first in the direction of Oshkosh. There he found that none other than pine land was subject to entry, and this he did not desire. He then retraced his steps toward Milwaukee and started westward. He learned that good land could be obtained in Eagle Township, and accordingly he entered the parcels described above-heavily timbered land nine miles north of Wisconsin River. Here he grappled with the forests and carved out a prnductive farm, in complete contrast with those farms of sandy soil on the south bank of the river.

C. R. Pickering, Muscoda.

\section{ST. CROIX COUNTY}

S. H. Burr Homestead. (1) Description of the land: $\mathrm{N} 1 / 2 \mathrm{NW} 1 / 4$, N $1 / 2$ NE $1 / 4, N 1 / 2$ SE $1 / 4$ Sec. 30 , T 28N, R 18W, Town of Kinnickinnick. 
(2) Maker of the farm: Solomon Hale Burr, native of Conway, Massachusetts. (3) Origin of title: Warranty deed from George W. Pratt, 1855. (4) Date of settlement on the land: April, 1855. (5) Present owner: Mrs. Louie Burr Fuller, daughter of Solomon H. Burr. (6) Date of report: Jan. 19, 1921.

Mr. Burr's first home in the West was at Princeton, Illinois, where he remained for twenty-two years. His Wisconsin farm was only one and onehalf miles from River Falls, and is today one of the most picturesque farms on the well-known Kinnickinnick trout stream. During the antislavery contention Mr. Burr was a co-worker of Owen Lovejoy and a firm friend of the fugitive slave.

Mrs. C. W. Fuller, River Falls.

George W. Fuller Honestead. (1) Description of the land: NE $1 / 4$ NW $1 / 4$, SW $1 / 4$ NW $1 / 4$, NW $1 / 4$ NW $1 / 4$ Sec. 22 , T $28 \mathrm{~N}, \mathrm{R} 18 \mathrm{~W}$, Town of Kinnickinnick. (2) Maker of the farm: George W. Fuller, native of Madison, Ohio. (3) Origin of title: Warranty deed from James G. Crowns, 1854. (4) Date of settlement on the land: 1855. (5) Present owner: Frank N. Fuller, son of George W. Fuller. (6) Date of report: Jan. 18, 1921.

When Mr. Fuller bought his farm in the town of Kinnickinnick, about ten acres were cleared and there was a log house on it. Soon he put up a frame dwelling, hauling the lumber from Eau Galle. The nearest market was Hudson, fifteen miles distant. Mr. Fuller was a power in promoting whatever was best for his community.

Frank N. Fuller, River Falls.

\section{SAUK COUNTY}

Solomon King Homestead. (1) Description of the land: NE $1 / 4 \mathrm{NW} 1 / 4$ and $\mathrm{S} 1 / 2$ NW $1 / 4$ Sec. 3 , T $10 \mathrm{~N}, \mathrm{R} 6 \mathrm{E} ; \mathrm{W} 1 / 2$ SE $1 / 4$ and E $1 / 2 \mathrm{SW} 1 / 4$ Sec. $34, \mathrm{~T} 11 \mathrm{~N}, \mathrm{R} 6 \mathrm{E}$, all in the Town of Sumpter. (2) Maker of farm: Solomon King, native of Ohio. (3) Origin of title: U. S. Govt. patent and private purchase, 1848. (4) Date of settlement on the land: 1856. (5) Present owner: Elias D. King, son of Solomon King (all but three acres has been sold). (6) Date of report: Dec. 19, 1920.

The IKing homestead is unique in the following particulars:

1. It contains the "first circular silo on route 12 between Baraboo and Prairie du Sac."

2. Its owner was the "first to use galvanized steel roofing, and also to use tiling for draining the farm."

3. Its owner was the "first to practice subsoiling of land, which was done with profit."

Elias D. KING, Prairie du Sac.

\section{WALWORTH COUNTY}

Anson B. Warner Homes'iead. (1) Description of the land: W 1/8 SW $1 / 4$ Sec. 6, T 4N, R 15E, Town of Whitewater. (2) Maker of farm: Anson B. Warner. (3) Origin of title: Purchase from Hoppins family, 1847. (4) Date of settlement on the land: 1847. (5) Present owner: H. R. Warner, grandson of Anson B. Warner. (6) Date of report: Jan. 3, 1921.

Anson B. Warner paid $\$ 9.00$ an acre for the land; the present owner would not sell it for $\$ 350$ an acre. Originally the north half of the farm was covered with scattered oaks and bazel brush. Some of the remainder had been broken with an ox team, but the work had been so poorly done that it had to be done 
again. A log house served as a home for the family for three years. This was replaced by a frame house which stood for fourteen years. The present brick house dates from about 1864 .

H. R. WARNER, Whitewater.

\section{WASHINGTON COUNTY}

William Murray Honestead. (1) Description of the land: E $1 / 2 \mathrm{NW}$ $1 / 4$ and NE 1/4 SW 1/4 Sec. 33, T 12N, R 20E, Town of Farmington.

Maker of the farm: William Murray, born in 1815, in Scotland. (3) Origin of title: U. S. certificates of purchase, 1848 and 1854. (4) Date of settlement on the land: 1848. (5) Present owner: William A. Murray, son of William Murray. (6) Date of report: Dec. 15, 1920.

The Murray homestead is now a dairy farm. Three gravel pits are also a source of income.

Merton W. Murray, West Bend.

\section{WAUKESHA COUNTY}

JAOKSON KeMPer Homestead. (1) Description of the land: NW 1/4 Sec. 18, T 7N, R 18E, Town of Merton, and lots 1 and 2 and NE fr. 1/4 Sec. 13, T 7N, R 17E, Town of Summit. (2) Maker of the farm: Jackson Kemper, bishop of Wisconsin. (3) Origin of title: In part from the Territory of Wisconsin by Henry Dodge, governor; a patent dated July 17, 1846; and s part from United States by patent January 1, 1850. (4) Date of settlement on the land: 1846. (5) Present owner: Mary Ann Kemper Lemon, granddaughter of Jackson Kemper. (6) Date of report: Apr. 18, 1921.

Bishop Kemper's farm was adjacent to Nashotah Mission. The road passing the house was a military road from Fort Dearborn to Fort Winnebago; it is said that Jefferson Davis laid it out and worked it. The road was also used by the lead miners of Galena, Illinois, who were often seen with four or six yoke of oxen hauling wagons loaded with pig lead.

The Bishop always employed a farmer to work the land. The house as it now stands consists of a frame portion built in 1846 and a stone addition erected in the early sixties. The Kemper home was for many years the center of hospitality for all connected with Nashotah House.

Mrs. Charles H. Lemon, Milwaukee. 

INDEX 



\section{INDEX}

Ableman, horse prizes for, 120.

Adams, Gilbert, horse breeder, 119.

Adams County, topography of, 3, 131; foreign born in, 49; wheat production in $1860,136$.

Addison County (Vt.), farms in, 59. Agricultural revolution, 149-164.

Agricultural Society. See Wisconsin State Agricultural Society.

Albany (N. Y.), as a market, 58-59. Alderneys, at state fair of 1860, 116.

Allegheny River, transportation on, 59.

Alluvial soil, defined, 7 .

America, colonial, exports of wheat from, 82.

Americans, as Wisconsin immigrants, $45-49,57-64,78$; in northern Wisconsin, 141; as dairymen, 162. See also the several sections and states.

Appleby, John F., invents "knotter," 89, 93.

Arena, on Wisconsin River, 26, 41.

Argyle, on edge of prairie, 18.

Ashland County, population of, 145.

Aspen trees, in Wisconsin, 17.

Ayrshires, at state fair of $1860,116$.

Aztalan, goods for, 69-70.

BABCOCK, Stephen Moulton, invents milk tester, 160 .

Baden, emigrants from, 53.

Bangor, in LaCrosse County, 54; wheat crops in, 93-94.

Baraboo River, settlement begun on, 130.

Barber, Milton, dairyman, 153.

Barley, production of, 102.

Barns, types of, 67-69, 79, 167.

Barron Hills, location, 2.

Baseball, introduced, 175.
Bavaria, emigrants from, 53.

Bayfield County, population of, 145 .

Bear valley (Richland County), dairying in, 155.

Beckley, Hosea, History of $\nabla$ ermont, 62.

Beckwith brothers, Bear valley dairymen, 155.

Belgian, breed of horses, 120.

Beloit, settlements near, 33; ferry at, 74 .

Bennington County (Vt.), farms in, 59.

Berkshire, breed of swine, 113.

Berkshire Agricultural Society, founded, 113.

Big Quinisee Falls, surveys reach, 135.

Binders, in harvest fields, 87 ; invention of self, 89.

Birge, Mrs. Imogene Starin, donor, 65.

Birge, Julius C., letter, 68.

Black, James A., cheese factory promoter, 156.

Black Hawk War, importance of, 26.

Blackhawk, breed of horses, 117 118; distribution of, 118.

Black River, lumbering on, 132.

Black River Falls, topography of, $3,8$.

Black River valley, surveyed, 135.

Blasting, mode of stumping, 131.

Blue Mounds, road via, 74 .

Blue River, topography of, 12-13; dairying in valley, 156.

Bonanza farming, described, 88.

Boston, as a market, 59.

Bottomley, Edwin, English settler, 56, 76.

British. See English and Scotch. 
British agriculture, crisis in, 83; decline of wheat growing, 83 .

British-Americans. See FrenchCanadians.

British régime, in Wisconsin, 23-24.

British Temperance Emigration Society, colony, 56 .

Brighton (Kenosha Co.), dairy products, 151.

Bristol (Kenosha Co.), dairy produets, 151.

Brookfield, in Waukesha County, 51-52; foreign born in, 54 .

Brooklyn, horse prizes for, 120.

Brooks, Seymour, exhibitor, 116; dispersal sale of shorthorns, 116.

Brown County, soil, 144; forested area, $13,17,40$; population in 1836, 27; map of, 28 ; foreign born in, 57 ; corn grown in, 100.

Buffalo (N. Y.), lake port, 64 .

Buffalo County, driftless area of, 10 ; forested area, 17; soil of, 144; foreign born in, 53 ; wheat production in, 95, 136-137.

Buffalo valley, surveyed, 135.

Bull, Stephen, horse breeder, 119.

Bulls, confined, 115.

Burlington, road to, 76 .

Burnett County, forested area, 17.

Burrows, George B., bequest, xii; home of, 58.

Buschbauer, Hans, agricultural leader, 163.

Butter, production of, 97 .

Byfield, breed of hogs, 115.

CaIrd, Sir James, Prairie Farming in America, 63.

Caledonia, in Columbia County, 54 .

California, emigration to, 90 .

Calumet County, forested area, 13, 40.

Cambria, in Columbia County, 54.

Cambrian rocks, location, 3, 5, 8-11, 19.

Camp Douglas, rocks near, 3.
Camp meeting, in Racine County, 172.

Canada, Wisconsin a part of, 1; emigrants from, 57. See also French-Canadians.

Carswell, John A., prominent dairyman, 155.

Case, Jerome I., threshing machine inventor and manufacturer, 89; horse breeder, 119.

Cassville, mining town, 26.

Castle Rock, wheat grown in, 94 .

Cataract, in Monroe County, 56.

Cattle, imported, 6; increase of, 97 ; distribution of, 101-102; exhibits of, 115; feeders, 166 . See also the several breeds-Ayrshire, etc.

Cayuga County (N. Y.), dairymen, 155.

Census of 1836, population, 27.

Census of 1850 , statisties, $37,44,54$, 64 ; described, 45 ; analyzed, 4656 ; manuseript schedules, 46.

Champlain Lake, farms on, 58-59; transportation on, 61,64 .

Cheese, increased production of, 97 ; imported, 154; dairying for, 151; makers, 160.

Cheese press, illustration, 151.

Cheshire, breed of swine, 113.

Chicago, trail from, 26, 32, 35, 74, 77 ; effect on settlement, 31 ; canal project, 32 ; lumber eompanies, 67-68; lake port, 70, 78; dairy market, 151.

Chicago and Northwestern Railway, route, 12.

China pig, breed of swine, 113.

Chinch bug, damages by, 93.

Chippewa County, soil of, 144.

Chippewa Indians, in Wisconsin, 1; land cession, 134.

Chippewa River, lumbering on, 44, 68, 132.

Chippewa valley, survey in, 135 .

Chittenden County (Vt.), farms in, 59.

Churches. See Rural churches. 
Circus, children's day at, 177.

Civil War, effect on agriculture, 84; on agricultural machinery, 88 ; on horse breeding, 118.

Clam River, surveys reach, 135.

Clapp, N. B., exlibitor of purebred sheep, 114.

Clark, Charles MI., cited, 117.

Clark, Hiram C., History of Chenango County, 62.

Clark, John M., exhibitor of "General Gifford," Morgan horse, 118; home of, 72 .

Clearing. See Lands.

Clover, in rotation with wheat, 95; spread of culture of, 110.

Clydesdale, breed of horses, 120 .

College of Agriculture, influence on dairying, 154, 159-161; extension division, 160 ; stumping experiments, 143.

Columbia County, foreign born in, 54-55; farms, 78; frame houses, 78 ; grain production in, $99-100$, 102.

Commons, for early settlers, 36, 78 .

Communism, in Wisconsin, 57.

Connor, L. G., Sheep Industry, 122.

Cooperstown, in Manitowoc County, 52.

Copeland, Louis A., "The Cornish Element in Southwestern Wiscon$\sin , " 49$.

Corn, grown in South, 81; not adapted to Wisconsin, 98; increased production, 97 ; types of, 98 ; best lands for, $98-99$; production by counties, 99 ; table of, 102 ; substitute for wheat, 99 .

Corn Laws, in England, 82.

Cornish, in Wisconsin, 48-49, 56.

Cotswold, breed of imported sheep, 113.

County fairs, promote good livestock, 113.

Courtland, in Columbia County, 54 .
Cows, dual purpose of, 158; number of purebreds, 164. See also Cattle.

Cradle, harvesting implement, 87 ; illustration, 92.

Cradlers, in harvest fields, 87.

Cram, Captain T. J., map of 1839 , 40.

Crawford County, in driftless area, 10; forested area, 17; prairies in, 18 ; population in 1836,27 ; map of, 28 ; settlements in, 42,79 ; foreign born in, 57.

Creamery, illustration, 161.

Crookes, Sir William, cited, 81.

Curtler, W. H. R., History of English Agriculture, 83.

Cushing, Caleb, buys Wisconsin land, 30.

DAIRY School in Wisconsin University, founded, 160; illustration, 160.

Dairying, in Vermont, 62; before factory system, 149; in 1860 summarized, 152-153; products, 105 106 ; new methodology of success, 179 ; effect on farming, 164.

Dairymen's Association. See Wisconsin Dairymen's Association.

Dames, William, Wie Sieht Es in Wiskonsin aus, 38, 53.

Dances, as community exercises, 175-176.

Dane County, driftless area of, 10 ; early settlements, 36,78 ; towns in, 43; foreign born, 50-51, 53, 56 ; grain production in, $99-100$, 102, 136; livestock in, 103; rural population, 147.

Danes, in Wisconsin, 47, 51, 145.

Dayton, prize horses in, 120.

De Forest, bonanza farm in, 88 .

Delafield, in Waukesha County, 54.

Delavan, settled, 33 .

Delaware River, transportation on, 59. 
Devon, breed of cattle, 113-114, 155; illustration, 116.

Dickey, A. P., horse breeder, 119.

Diversified farming, discussed, 97 129 ; area, 104 ; effect on immigration, 111; changes toward, 109, 111.

Dodge County, geology of, 5; forested area, 13, 40; foreign borm in, $52-53,57$; roads in, 76 ; farms in, 78; grain production in, 99100, 102, 136.

Dodgeville, mining town, 26.

Door County, forested area, 17, 40; timber burned, 142; soil, 144; wheat production in, 136 ; fruit, 165.

Douglas County, population in 1845, 144.

Dousman, George B., at Milwaukee, 69-70.

Drift, defined, 7-8; effect on swamps, 19.

Driftless Area, location, 3, 6-7 ; map of, 9 ; described, $9-13$; free from marshes, 19; lead mines in, 24; settlement in, 91.

Dubuque, Julien, lead miner, 24.

Dubuque County (Ia.), lead mines in, 24.

Dunkirk (N. Y.), as a terminus, 63.

Dunn County, prairies in, 10 ; soil of, 144 .

Durham, breed of eattle, 155 ; illustration, 116.

Dutch, in Wisconsin, 38, 47, 57.

Dwight, Timothy, Travels in New England and New York, 65, 77.

EAGLE, wheat growing in, 94.

Eaton, H. L., Bear valley dairyman, 155.

Eau Claire County, driftless area of, 10 ; soil, 144.

Edwards, S. B., hog breeder, 127 128.

Eilson, Elling, home of, 52.
Elkhorn Prairie, loeation, 18; settled, 33.

Elmira (N. Y.), as a terminus, 63.

Emerson, Ralph Waldo, buys Wisconsin land, 30.

Emigration, from Wisconsin, 139; from poor farms, 178.

Emmet, in Jefferson County, 54.

Empire, in Fond du Lac County, $54,94$.

Enclosures-1851-71, in England, 83.

English, in Wisconsin, 46, 49-50, 54, 56-67. See also Cornish.

English Prairie. See Muscoda.

Episcopalians, in Wisconsin, 57.

Erie Canal, importance of, 59, 63.

Erosion, effects of, 10-13, 19, 21.

Esterly, George, invents harvesting machine, 88, 92.

European immigrants. See the several nations.

Everett, Edward, buys Wisconsin land, 30.

Factory system, in New York, 154.

Farm life in Wisconsin, 165-181; effects on children, 172-173; combined with lumbering, 140-141.

Farmers' institutes, influence of, 161.

Favill, Asa, pioneer dairyman, 153.

Favill, Stephen, famous dairyman, 153.

Feed producing area, limits of, 104.

Fences, kinds of, 167.

Fennimore, valley at, 13; dairying in, 156.

Ferries, in pioneer Wisconsin, 74.

Fever River, steamboats on, 26.

Finns, in New North, 145.

Fish, H. Z., cheese maker, 156.

Fish, in northern Wisconsin, 148.

Flambeau Ridge, location, 2.

Florence County, forested area in, 141, 143. 
Fond du Lac, on edge of prairie, 18 ; settlement, 40 ; railroad to, 91.

Fond dn Lac County, forested area, 13, 40; foreign born in, 52, 54, 56-57; roads in, 76; farms, 78 ; grain production, 100,102 ; livestock, 103; dairying, 153.

Food, easily procured by pioneers, 70-71.

Foreigners, in early settlements, 37$40,45-57,79$; assimilation of, 168; farm localities of, 178; artizans among, 168. See also the several nationalities - Dutch, English, Germans, etc.

Forest County, forested area in, 141.

Forests, area of, 13, 17, 19, 21-22; map of, 16 ; clearing of, 22,76 77 , 143 ; burned tracts in, 141 142 ; relation to wheat growing, 95.

Fort Crawford, location, 12; trail to, 26 ; road to, 74 .

Fort Howard, road to, 12, 74.

Fort Winnebago, location, 12 ; trail to, 26 ; road to, 74 ; timber for, 132.

Foster, Mary Stuart, aid acknowledged, xiii, 25.

Four Lakes region, topography, 12.

Fowler, Joln, Journal of a Tour in the State of New York, 64.

Fox Indians, in Wisconsin, 1.

Fox River, buried forest on, 13; forests on, 19; farming, 41.

Fox River Canal, plans for, 78; opening of, 134.

Fox River (Pishtaka) of the Illinois, settlement along, 32-33, 36, $50,56$.

Fox- $W$ isconsin waterway, historical importance of, 1 ; as a boundary, 18, 26-27.

Franklin, settlement of, 38, 54 .

Franklin County (Vt.), farms in, 59.
Freistadt colony, in Washington County, 52.

French régime, in Wisconsin, 23-24, 43.

French-Canadians, in Wisconsin, $47,57$.

Furniture, in pioneer Wisconsin, 69-70.

Fur trade, era of, 23-24.

Garena (IIl.), lead mines near, 24, 26 ; road to, 74 .

Galena-Blackriver, strata, 5, 10, 24.

Game, early abundance, 71 ; in northern Wisconsin, 148.

Gardening, among foreign settlers, 168.

Gardner, David, pioneer, 69-70.

Garland, Hamlin, A Son of the Middle Border, 89, 167.

Gascoyne, Philip, pioneer dairyman, 151.

Genesee, in Waukesha County, 54, 57.

Geneva Lake, settlements near, 33; contest at, 73.

Geology, of Wisconsin, 1-22.

Germans, in Wisconsin, 38, 47, 4954, 78, 141.

Glacial action, in Wisconsin, 6-9, 13.

Goff, Emmett S., investigates northern Wisconsin, 140.

Grant, Ulysses S., Report on the Lead and Zine Deposits, 24, 44.

Grant County, in driftless area, 10; prairies in, 18; lead mines in, 24; part of Iowa County, 27; native born in, 47-48; foreign born, 49, 56-57; grain production in, 99100, 102; swine in, 103; butter sale, 149.

Grasses, relation to dairying, 106107.

Great Britain. See British agriculture.

Great Plains, wheat growing in, 82 . 
Green Bay, forest on, 13, 17, 19; towns on, 41, 43-44; sawmills, 130.

Green Bay (town), fort at, 12, 74; early settlement, 23 ; trail to, 26, $35,74,77-78$; land office at, 30 .

Green County, geology of, 5; driftless area of, 10 ; prairies in, 18; lead mines, 24,48 ; towns in, 43 ; roads, 76 ; native born in, 47 ; foreign born, 49, 54; grain production in, 99-100; dairying in, 152-153.

Green Lake County, wheat raising in, 95, 136.

Groves, H. D., breeder, 114.

Guernsey, breed of cattle, 164.

Gypsum, used on clover, 95.

"Hambletonian," blooded horse, 114.

Hamilton, William S., lead mine pioneer, 41.

Hard times, among farmers, 90-91.

Harvest, inventions for, 87-88; labor, 87 ; in 1853, 91.

Hay, from marshes, 85 ; increased production of, 97 ; statistics, 101 102.

Hazel Green, on edge of prairie, 18.

Hazen, Chester, famous dairyman, 157.

Heart Prairie, houses on, 67; home of inventor, 88.

Helena, settlement of, 41.

Henry, William A., founds the short course, 159; dairy school, 160; Feeds and Feeding, 160; Northern Wisconsin, 140-145; portrait, 150.

Herds, process of improving, 180; books for registry, 113. See also Cattle.

Hereford, breed of cattle, 116.

Herkimer County (N. Y.), dairymen, 155.

Hibbard, B. H., History of Agriculture in Dane County, 109, 111.
Hickory trees, in Wisconsin, 17.

Highland, wheat growing in, 94.

Hiram Smith Hall, illustration, 160.

Hinckley, B. M., 155.

Hoard, William D., program of dairy development, 154, 157-159; editor, 156; portrait, 150.

Hogs, in early Wisconsin, 71, 97; improvements in breeds, 113,126 129 ; distribution of, 103 ; first exhibit of, 115.

Holland, emigrants from, 38, 47, 57.

Holstein, breed of cattle, 164.

Hops, furore for growing, 109.

Horses, distribution of, 97, 103; substitute for oxen, 107; entries at state fair, 113; breeds of, 117 121 ; breeders, 119 .

Horticultural Society. See Wisconsin Horticultural Society.

Hoyt, John W., early agriculturalist, 92,159 ; sketch of, 108-109; portrait, 107.

Hudson River, transportation on, 58-59.

Hughes, John, Welsh settler, 54.

Huron Indians, in Wisconsin, 1.

Illinois, driftless area in, 9 ; lead mines, 24, 31; boundary, 18, 26, 43 ; settlers from, 26, 47-48; canals in, 32 ; lumber market, 68 , 132; wheat growing in, 84; horse prizes for, 120 ; source of sheep supply, 123.

Illinois River, tributaries, 32.

Immigration, state board created, 140.

Indiana, settlers from, 47; colony in, 57; wheat growing in, 84; source of sheep supply, 123.

Indians, of Wisconsin, 1, 23-24; land cessions, 26, 134.

Interest rates, extortionate, 91 .

Iowa, driftless area in, 9; lead mines, 24 ; lumber market, 68 , 132. 
Iowa County, in driftless area, 10; lead mines in, 24; population in 1836,27 ; map of, 28 ; native born in, $47-48$; foreign born in, 49,54 , 56 ; grain production, 99-100; swine in, 103.

Irish, in Wisconsin, 38, 45-46, 49, 51-52, 54, 57.

Iron County, population of, 145 .

Ixonia, in Jefferson County, 52, 54.

JACOBSON, Edna Louise, aid acknowledged, xiii; compiles Census of Old Homesteads, 186-193.

Jackson County, topography of, 3 ; in driftless area, 10; soil of, 144 .

Janesville, settlements near, 33, 69; roads to, 74,79 ; horse prizes for, 120.

Jarvis, Consul William, imports merino sheep, 113, 122.

Jefferson County, geology of, 5; forested area, 13, 40; farm lands in, 31,79 ; settled, 33,36 ; towns in, 43 ; foreign born in, $52-54,56$; grain production in, 100, 102; dairying promoted in, 157.

Jefferson County Union, influence on dairy development, 157.

Jersey, breed of cattle, 164.

Jo Daviess County (IIl.), lead mines in, 24.

Johnston, James, pioneer miner, 26.

Juneau County, topography of, 3; in driftless area, 10; wheat production, 136.

Kaxsas, Wisconsin people in, 139.

Kegonsa Lake, location, 18.

Kelley, _- horse breeder, 119.

Kellogg, Lonise P., aid acknowledged, xiii; "Story of Wisconsin," 23,80 .

Kenosha, lake port, 32; frame houses at, 67 ; lumber for, 68 ; road to, 76 .

Kenosha County, forested area, 13; prairies in, 18; settlements, 33,
37,77 ; established, 33 ; towns in, 43 ; density of population, 44 ; native born in, 48-49; foreign born, 56 ; houses in, 67 ; improved lands in 1850, 86; livestock, 103, 114; grain production in, 95, 99100 ; dairying, 151-152.

Kentucky, settlers from, 26, 47-48; horses, 118-119; wheat growing in, 84.

Kewaunee County, forested area, 17,40 ; soil of, 144 ; wheat production in $1860,136$.

Kichtmyer (Kichtneys), Nicholas, Kenosha dairyman, 151.

Kickapoo River, lumbering on, 135.

Kilbourn, topography of, 3,8 .

King, F. A., investigates northern Wisconsin, 140.

King, Rufus, "The New York and Erie Railroad," 63.

"King of Cymry," blooded horse, 117.

Kirchayn, in Washington County, 52.

Kittle, William, The History of the Township and Village of Mazomanie, 56.

LACHER, J. H. A., early taverns and stages, 80.

La Crosse, lumber port, 135; railway to, 91, 135.

La Crosse County, in driftless area, 10; prairie in, 19; foreign born in, 54 ; soil of, 144 ; wheat production, 136.

La Crosse Prairie, location, 19; houses on, 68-69.

Lafayette, in Monroe County, 56.

Lafayette County, in driftless area, 10; prairies in, 18; lead mines in, 24 ; part of Iowa County, 27; native born in, 47-48; foreign born, 49, 54, 56; grain production, 99-100; swine in, 103. 
Lakes, inland, 2 ; formed by glaciers, 7; none in driftless area, 11.

Lands, characteristies, 1-22; classification, 27; sales offices, 30 ; clearing methods, 76-77; prices, 143; improved area in 1850 and 1860, 86-87; burned over, 142 ; cut over, 142; sale of school, 91.

Langlade County, forested area, 141.

Lathrop, S. P., cited, 114.

Lawe, John, pioneer lumberman, 68.

Lead mines, location, 24-27; trails in, 25,74 ; map of, 25 ; as a market, 31 ; markets for, 40 ; local government of, 43 ; native born in, 48 ; foreign born, 49 ; railroads in, 79. See also Grant, Iowa, and Lafayette counties.

Lebanon, in Dodge County, 52.

Legler, George, dairyman, 153.

Leicester, breed of hogs, 113, 115.

Levi, Kate A. Everest, "German Immigration to Wisconsin," 5253.

Linden trees, in Wisconsin, 17.

Lisbon, in Waukesha County, 57.

Liverpool (England), emigrants from, 56.

Livestock, increase of, 97 ; at first state fair, 113; purity of blood, 113-114; grades improved, 121122, 166. See also Cattle, Hogs, Horses, and Sheep.

Livingston, Chancellor Robert R., importer of merinos, 113.

Local government, in Wisconsin, 42-43.

Lodi, on edge of prairie, 18 ; wheat growing at, 94.

Loess soil, defined, 7.

Log cabin, types of, 66, 68 .

Louisiana province, Wisconsin's relations to, 1.

Luchsinger, John, on New Glarus, 50.
Lumbering, early operations, 17,22 , 40,44 ; by farmers, $39,67-68,76$, 130-148; market for farm products, 44; kinds of woods, 139-140; values of, 132-133; market for, 132 ; illustrations, 133.

Lumbermen, emigrated from state, 139.

Luxemburg, emigrants from, 53.

Lyon, Lucius, surveyor, 30.

McCashin Mountain, location, 2.

MeCormick, Cyrus, invents reaper, 88.

McCormick Reaper Company, 88.

MeKinnon, Captain —, importer of "King of Cymry," 117.

McMillan, Morrison, cited, 69.

Madison, on edge of prairie, 18; made the capital, 41 ; road to, 74 , 79 ; horse prizes for, 120.

Magdeburg (Germany), emigration from, 52.

Maine, settlers from, 47.

Manitowoc, sawmill at, 68.

Manitowoc County, buried forest in, 13 ; forested area, 17, 19, 40, 68; foreign born in, 47, 52-54; grain production in, 100, 102.

Maple trees, areas of, 13, 16-17, 22.

Maps:

United States, 2.

Wisconsin geological, 4.

Driftless area, 9.

Prairie areas, 14-15.

Forested area, 16.

Swamp land, 20.

The lead region, 25 .

Counties in 1836, 28.

Surveyed section in 1836, 29.

Mount Pleasant, 34.

Township organization, 1848, 42.

Population in 1850, 48.

Vermont and New York canals, 60.

Lines of communication, 1844, 75 .

The New North, 138. 
Marathon County, driftless area of, 10 ; leads in rural population, 145-146; farm in, 142.

Marinette County, forested area, 141.

Markets, for local customers, 150; for cereals, 102; for dairy products, 149; for American cheese, 154; city commission merchants, 151; foreign, 81, 154.

Marquette County, foreign born in, 54; Muir farm, 55; soil of, 144; oak openings in, 131 ; wheat production, 136.

Marsh harvester, value of, 88.

Marsh land, amount of, 7 ; areas, 17, 19, 35; map of, 20.

Martin, Lawrence, The Physical Geography of Wisconsin, 13, 22.

Maryland, wheat growing in, 84 .

Massachusetts, settlers from, 47; pioneer life in, 65.

Mazomanie, English colony at, 56; horse'prizes for, 120 .

Menominee Indians, in Wisconsin, 1; land cession, 134.

Mequon, in Ozaukee County, 52.

Merinos, imported, 113; illustrations, 117, 124.

Merk, Frederick, Economic History, 109.

Meyer, Balthaser H., "Railway Legislation," 41; home of, 174.

Meyer, Casper Henry, portrait, 53.

Michigan, settlers from, 47.

Michigan Lake, as a boundary, 1, $18,26,43$; forests on, 13,68 ; lumbering, 132; ports, 31, 33, 80; transportation on, 63 .

Michigan Territory, Wisconsin a part of, 30 .

Military Ridge, location of, 12-13, 74 ; prairies near, 18, 79.

Mills, in early Wisconsin, 39; at Whitewater, 67 ; on lake sbore, 68 ; grist, 71-72; saw, 130, 133; sites for, 73 .
Milwaukee, location, 31 ; enterprise, 32 ; land office at, $35,67,72$; as a port, $39,50,53,69,78$; foreign born at, 53 ; lumber for, 68 ; center for roads, 74,79 ; dairy market, 151.

Milwaukee and Mississippi Railway, built, 41-42, 91; value of, 135 .

Milwaukee and Rock River Canal, projected, 32, 37.

Milwaukee County, forested area, 13, 78; boundary, 33 ; original area, 27-28; farm lands in, 30 , 78 ; foreign born in, $37-38,40,47$, $53-55,57$; towns in, 43 ; density of population, 44 ; grain production, 99, 102; dairying in, 152.

Milwaukee River, settlement on, 52.

Mineral Point, mining town, 26; land office at, 30 ; road to, 74,76 .

Mining region, settlement, 24-27. See also Lead Mines.

Minnesota, driftless area in, 9 ; Wisconsin people in, 139.

Mississippi River, as a boundary, 1-2, 18; erosion, 10-11; prairies on, 19 ; steamboats on, 26, 41 ; transportation on, 31-32, 135; lumbering on, 44, 68 ; pineries on, 132.

Mississippi Valley, lumber market, 132.

Missouri, settlers from, 26, 48; lumber market, 68, 132.

Mitchell, Alexander, financial pioneer, 55.

Mohawk River, transportation on, 59.

Mohawk valley, settlers from, 65 .

Monroe County, topography of, 3; in driftless area, 10 ; foreign born in, 54 ; soil of, 144 ; wheat production in, 136.

Morgan, line of blooded horses, 117118, 121.

Morrill Law, for agricultural colleges, 159. 
Mortgage, indebtedness, 91.

Motor car, effect on good roads, 179.

Mount Pleasant Town, settled, 3337 ; map of land entries, 34 ; foreign born in, 54 , 167; improved lands in 1850, 85; grain production, 93, 99; sheep raised in, 124.

Muir, John, The Story of My Boyhood and Youth, 55, 173; homes of, 66, 174.

Murray, George, stock bieeder, 55, 116-117, 119.

Muscoda (English Prairie), trail to, 26,41 ; wheat in, 94 ; board of trade, 156.

Music, Welsh contributions, 55.

Nashotah, Episcopal seminary at, 57.

Natesta, Henry, home of, 168.

Neapolitan, breed of hogs, 115.

Nebraska, Wisconsin people in, 139.

Necedah Hill, location, 3.

New Diggings, mining town, 26.

New England, settlers from, 37, 4749, 57-64; pioneer days in, 64-65; wheat growers in, 84; surplus dairy products, 154.

New Glarus, colony of Swiss, 49-50, 54 ; wheat growing in, 94 ; chureh at, 59 .

New Hampshire, pioneer days in, 65-66.

New Jersey, settlers from, 58.

New North, region defined, 137; map of, 138; population at several censuses, 136-137, 139, 145; farming conditions in, 137, 147; foreign born in, 146; native born, 139. See also Northern Wiscon$\sin$.

New York, settlers from, 37, 52, 54, $57-64,69,78$; farm lands in, 30, $62-63$; statistics of settlers from, 47-48; pioneer days in, 65 ; wheat growing, 84; influence on dairy progress, 154-155.
New York Board of Agriculture, Reports, 155.

Newton, John W., dairyman, 153.

Newton, in Manitowoc County, 54; wheat growing in, 94.

Niagara limestone, location, 3-5.

Nikima, in Fond du Lac County, 54.

North Carolina, settlers from, 48.

Nortl Dakota, Wisconsin people in, 139.

Northern Wisconsin, oak openings in, 131; agricultural conditions, 133-134; wheat growing in, 95. See also New North and Old North.

Northern Wisconsin Agricultural Association, Transactions, 147.

Norway, in Racine County, 50-51, 54; wool growing in, 125.

Norwegians, in Wisconsin, 47, 5051, 79, 141, 145.

OAK Grove, cheese factory at, 156.

Oak trees, areas of, 13, 16-17; openings described, 17; location, 18; advantages of, 85 .

Oats, as incidental crop, 85 ; increased production of, 97 ; range, 100-101; table of production, 102.

Ohio, settler's from, 47-49, 58, 63, 69 ; improved land in 1850, 87; wheat growing in, 84; surplus dairy products, 154.

Okee, horse prizes for, 120.

Old Lutherans, in Wisconsin, 52.

Old North, area defined, 136; population statisties, 136-137. See also Northern Wisconsin.

Oneida County (N. Y.) foresterl area in, 141; dairymen, 155.

Ontario County (N. Y.), dairymen in, 155.

Openings. See Oak trees and Prairies.

Oshkosh, settlement, 40 ; wheat crop in, 93 ; headquarters of Northern Wisconsin Agricultural Association, 147. 
Ottawa (Ill.), Norwegians at, 50.

Ottawa (Wis.), in Waukesha County, 54.

Outagamie County, forested area, 13; oak openings in, 131; soil of, 144; wheat growing in, 136.

Owen, Robert Dale, communist, 57. Owenite community, in Wisconsin, 57.

Ozaukee County, forested area, 13, $17,38,40$; foreign born in, $52-$ 53 ; grain production in, 102.

PaNiC of 1837, effect on settlement, 31.

Paper towns, in early Wisconsin, 40.

Paris (Kenosha Co.), dairy prodnets, 151.

Pekatonica River, topography of, 12.

Peneplain, in Wisconsin, 6 .

Pennsylvania, settlers from, 47-48, $52,58,69$; improved land in 1850 , 87 ; wheat growing in, 84.

Penokee Range, location, 2.

Pepin County, forested area, 17; soil of, 144; wheat growing in, 136.

Percheron, breed of horses, 120 .

Pheil, Richard, horse breeder, 119.

Philipp, Emanuel, birthplace, 50.

Phillips, Laura J., "Colonization of Wisconsin by the Welsh," 54.

Pickard, Josiah L., school superintendent, 80.

Pierce County, geology of, 5 ; forested area, 17; soil of, 144; wheat growing in, 136.

Pigs. See Hogs.

Pike River, lands on, 35-36.

Pine trees, areas of, 13, 16-17, 19, $21-22,68,131$; durability of stumps, 143.

Pineries, effect on settlement, 21; on Lake Michigan, 68; on inland rivers, 68 ; work in, 130 ; illustration, 132. See also Lumbering.
Pink eye, horse disease, 90.

Pishtaka River. See Fox River of the Illinois.

Pittsfield (Mass.), county fairs originate in, 113.

Platteville, mining town, 26.

Pleasant Prairie (Kenosha Co.), dairy products, 151-152.

Pleasant Springs, in Dane County, 51,94 ; wheat crops in, 93.

Plymouth, census figures, 37, 54; wheat crops in, 94 .

Polk County, forested area, 17 ; soil of, 144; farm in, 175.

Population. See Wisconsin.

Pork, marketing, 107, 110. See also Hogs.

Portage, fort at, 12, 74; foreign born, 54 .

Portage County, topography, 3; driftless area of, 10 ; population in $1860,134$.

Potawatomi Indians, in Wisconsin, 1.

Powers, D. J., cited, 69.

Prairie du Chien, road to, 12, 74; early settlement, 23, 27; railroad to, 91 .

Prairie du Sac, settled, 41.

Prairies, in southern Wisconsin, 12, 18-19, 21-22, 35; maps of, 14-15; origin of, 13 ; importance of, 139 ; breaking of, 91 .

Price, P. A., dairyman, 153.

Primrose, wheat growing in, 94 .

QuAife, M. M., aid acknowledged, 37.

RACINE, lake port, $32-33,69$; pioneer, 55 ; lumber for, 68 ; road to, 76,79 ; wheat market, 85 .

Racine Argus, cited, 32.

Racine County, forested area, 13; prairies in, 18; farm lands, 31; improved land in 1850, 86 ; early settlements, 32-37, 77; towns in, 43 ; density of population, 44 ; 
native born in, 47-48; foreign born in, 50, 54-56; houses in, 67 ; grain production, 95, 99-100; livestock, 103, 116; dairying, 152. Railways, importance of, 41-42, 63, 78-79; laborers for, 51 ; building of, 91 .

Randall (Kenosha Co.), dairy produets of, 152.

Randolph, in Columbia County, 54 .

Reaping machines, 88.

Red Cedar River, lumbering on, 132.

Red Cedar valley, survey in, 135.

Rhinelander, center of immigration activity, 140.

Rib Hill, location, 2.

Richards, Griffith, Welsh settler, 54 55 ; hor'se prizes for, 121; portrait, 52.

Richards, Richard, stock breeder, 55, 115-116; horse breeder, 119; prizes, 120-121; portrait, 125.

Richland County, in driftless area, 10; forested area, 17; settlements in, 42, 79; native born in, 47 ; foreign born, 49 .

Ridge fields, described, 12; wheat grown on, 94.

Ripon, on edge of prairie, 18.

Ripon College, candidate for agricultural college grant, 159.

Roads, on ridge lands, 12,73 ; military, $12,18,41,74,79$; in mining region, 26; Chicago-Green Bay, $35,74,77$; conditions of, 73-76; plank, 76, 79 .

Robbins, J. V., dairyman, 153.

Roberts, William G., wheat grower, 93.

Rochester (N. Y.), Norwegians at, 50.

Rochester (Wis.), settlement, 32; road to, 79; wool market, 125.

Rock County, geology of, 5 ; prairies in, 18; settlements, 33, 37; towns in, $43-44$; roads, 76 ; native born in, 47-48; foreign born, 50,54 -
56 ; improved land in 1850,86 ; grain production, 99, 102; rank in several grains, 95, 100.

Rock Prairie, location, 18; early wheat crop on, 85.

Rock River, transportation via, 31 32 ; settlements on, $33,36,40,80$; marketing from, 41 ; ferry on, 74 .

Roe, John P., exhibitor, 115; owner of shorthorns, 116.

Rosendale, in Fond du Lac County, 54.

Rural churches, conditions of prosperity, 171-172.

Rural New Yorker, farm journal, 155.

Rural population, increase of, 181; in New North, 146.

Rural schools, influence of, 173174; in northern Wisconsin, 148.

Rush Lake, settlement on, 38 .

Russell, Harry L., bacteriological tests, 160.

Rutland County (Vt.), farms in, 59.

Rye, region of production, 102.

ST. Crolx County, geology, 5; prairie in, 19; soil of, 144; grain production in, 95, 100, 136-137.

St. Croix valley, survey in, 135; lumbering in, 132.

St. Lonis, lead mine metropolis, 26, 32.

St. Peter sandstone, location, 5, 10 11.

Salem (Kenosha Co.), dairy products, 152.

Sauk County, driftless area of, 10 ; forested area, 17; settlements in, 42 , 79 ; foreign born, 50,53 ; grain production, 100, 102; dairying, 153.

Sauk Indians, in Wisconsin, 1.

Sausage grinder, illustration, 169.

Sawmills. See Mills.

Saxony, emigrants from, 53. 
Scandinavians, in Wisconsin, 47, 50-51.

Schoolhouses, in Wisconsin, 80; illustration, 73.

School lands. See Lands.

Schools. See Rural schools.

Seotch, in Wisconsin, 46, 50, 55-57.

Scott, in Columbia County, 54.

Self binders. See Binders.

Shawano County, forested area, 141.

Sheboygan, lumber port, 67 ; sawmill at, 68 .

Sheboygan County, forested area, $13,17,40,68$; density of population, 44; foreign born in, 52-53, 57; grain production in, 100, 102.

Sheboygan Falls, population changes, 178.

Sheep, increased production of, 97; derivation of early flocks, 107, 123 ; entries at first state fair, 113; breeds, 114; distribution, 103; purebreds, 124; numbers, 107, 124; decline of raising, 126; illustration, 117. See also Wool.

Sherman, in Sheboygan County, 52.

Shire, breed of horses, 120.

Shorthorm, breed of cattle, 113, 115 ; source of, 114 ; prices, 117 ; breeding of, 116 .

Shot tower, on Wisconsin River, 41.

Showerman, Grant, A Country Chronicle, 177.

Shull, Jesse W., pioneer miner, 26.

Shullsburg, mining town, 26.

Silo, a French invention, 158; increase of, 158.

Simmons, James, Annals of Lake Geneva, 73.

Singing schools, community affairs, 174-175.

Sioux Indians, in Wisconsin, 1.

Six Nations Indians, in Wisconsin, 1.

Smith, Hiram, dairyman, 155.

Smith, Leonard S., The Water Powers of Wiseonsin, 22.
Soils, eharacter of, 21; in northern Wisconsin, 143.

Somers (Kenosha Co.), dairy products, 151-152.

Sorghum, production of, 109-110; effect of Civil War on, 110; decline of, 110 ; occasional revival, 111.

South Dakota, Wisconsin people in, 139.

Southdowns, importations of, 113.

Spanish, in the lead mines, 24.

Speculation, in Wisconsin lands, 3031.

"Spring house," illustration, 151.

Spring Prairie (Kenosha County), settled, 33; dairying in, 157.

Springvale, in Columbia County, 54.

Stage routes, in Wisconsin, 80.

Starin, Frederick J., diary, 65, 67, 77.

State Agricultural Society. See Wisconsin State Agricultural Society.

State Board of Immigration. See Immigration.

Stavangar (Norway), emigration from, 50.

Stevens Point, topography of, 3, 8 .

Stilson, Eli, wheat grower, 93.

Stock breeding, beginnings of, 55 , 71. See also Cattle, Hogs, Horses, and Sheep.

Storekeepers, bought dairy produets, 149; social function of, 177.

Stoughton, location, 18 ; horse prizes for, 120.

Stumping. See Lands.

Sub-earth vault, for curing cheese, 158.

Suburban farmers, 177-178.

Suffolk, breed of swine, 113 ; illustration, 124.

Sugar Creek, in Walworth County, 54; wheat raising in, 94; sheep, 124. 
Sun Prairie, on edge of prairie, 18; pioneers at, 69-70.

Sunday, working customs, 170-171.

Superior, population, 144.

Superior Lake, as a boundary, 1; lumbering near, 44; soils, 144; agriculture near, 144.

Surveys, in Wisconsin, 27-30; in northern Wisconsin, 134-135; for railways, 42 .

Susquebanna River, transportation on, 59.

Swamps. See Marsh land.

Swedes, in Wisconsin, 47, 51, 145.

"Swigert," thoroughbred horse, 120 ; illustration, 125.

Swine. See Hogs.

Swiss, in Wisconsin, 47, 49-50, 5354; as dairymen, 163.

Taverns, in Wisconsin, 80 ; illustration, 73.

Tennessee, settlers from, 47 ; wheat growing in, 84.

Thomas, L. G., early cheese maker, 155.

Thompson, John Giffin, Wheat Growing, 81, 95-96.

Threshing, changes in method of, 89.

Thwaites, Reuben G., Wisconsin, 23, 26; "Notes on Early Lead Mining," 26.

Tobacco, cultivation of, 109 .

Tourists, in nortlern Wisconsin, 148.

Towns, technical definition, xi, 42; surveyed, 27; Domesday Book studies of, 167.

Trails. See Roads.

Transportation, by inland waterways, $21,32,41,58-59,61$; railways, $41-42$; in pioneer days, $73-$ 76.

Trempealeau County, in driftless area, 10; prairie in, 19; soil of, 144; grain production in, 95,100 , 136.
Trempealeau valley, surveyed, 135. Trimble, William, "Historical Aspects of Surplus Food Production," 82.

Tripp, Dr. James, at Whitewater, 72.

Troy (N. Y.), as a market, 59.

Troy Lake, settlements near, 33 .

Tuttle, A. G., letter of, 130.

Two Rivers, sawmill at, 68 .

United States Geological Survey, charts, 33.

Utley, William L., horse breeder, 119.

VANDerpoel, Abram, letter, 32.

Vermont, settlers from, 37, 47-48, 58-64, 78; agriculture in, 59-62; pioneer days in, 65 ; sheep from, 114.

Vernon County, geology of, 5; in driftless area, 10; prairie in, 18; grain production, 100.

Verwyst, C. A., "Reminiseences of a Pioneer Missionary," 57.

Virginia, settlers from, $47-48$; wheat growing in, 84 .

WaLnut trees, in Wisconsin, 17.

Walworth County, prairies in, 18; farm lands, 31; settlements, 33, 37,67 ; towns, 43 ; native born, $48-49$; foreign born, 49,56 ; houses in, 67 ; roads in, 76 ; grain production, 95, 99-100, 102; dairying in, 152; sheep raising, 102, 124.

Warren, Emoly F., Sketches of the History of Chautauque County, 62.

Washington County, forested area, 40 ; roads in, 76 ; foreign born, $37-38,47,53$; grain production, 102.

Water power, in Wisconsin, 21; effect on settlement, 30 ; need for mill operation, 72 . 
Watertown, settlement, 40; foreign born in, 51 ; market day's at, 157.

Watson, Elkanal, originator of county fairs, 113; portrait, 106.

Waukesha County, forested area, 13, 40; farm lands in, 30 ; settlements, $33,36,79$; towns in, 43 ; foreign bo:n, 50-51, 53-57; houses, 07; grain production, 100, 102; sheep raising, 103.

Waunake, on edge of prairie, 18.

Waupaca County, geology, 3 ; soil of, $14 ;$; oak openings, 131 ; wheat raising, 136.

Waushara County, topography of, 3 ; foreign born in, 54 ; soil of, 144; wheat raising in, 144.

Webster, Daniel, buys Wisconsin land, 30.

Welsh, in Wiseonsin, 46, 49-50, 5456.

West Indies, market for wheat, 82.

Western states, supplied export wheat, 84.

Wheat, farorable locations for, 12, 91. 93; production of, 81-96; aereages, 85; harvesting, 87; prices, 85, 90; average consumption, 81 ; crops, 1837, 84-85; 1839, 81 ; 1819,82 ; 1860,92 ; exop failures, 90,92 ; decline of production, 97 : table of production, 102 ; marketing, 36, 41, 68, 80-82, 8990; forrign exports, 82.

Wheatland (Kenosha Co.), dairy products, 152.

Wheeler, R. MI., ommer of "Hambletonian," 114.

Whitheck, Ray H., monographs, 22.

White, W. C., Kenosha dairyman, 151.

Whitelall (N. Y.), terminus of canal, 59.

Whitewater, settled, $33,37,67$; foreign born in, 51,167 ; hmber înr, $67-68$; goods, 69 ; gristmill at, 72 73; lank breaking, 77; road to,
79; sleep in, 12t; first honse in, $6 \overline{7}$.

Whitney, Daniel, pioneer merchant, 41; lumberman, 132.

Wilcox, William, home of, 67 .

Wilder, C. H., eited, 154.

Tillard, Josiah F., cited, 42.

Williams, Charles H., stoek breeder, 55; exlibitor, 116.

Winnebago County, forested area, 13; foreign born in, 52, 54, 57; grain production, 100.

Wimnebago Indians, in Wisconsin, 1.

Wimnebago Lake, forests on, 17; prairies, 18, 77; towns on, 41, 43.

IVinslow, John B., Story of a Creat Court, 73 .

Tisconsin, plysiography, 1-22; population in 1850, 48; early settlements, 23-44; immigrants, 45-64; pioneer days in, 65-S0. See also New North, Northern Wisconsin, and Old North.

Wiseonsin Dairymen's Association, organized, 157.

Wisconsin Domesclay Bool, 167.

I'isconsin Farmer and Northwestern Cultivator, begun, 107, 111; purpose, 108; editors, 107-108; effect of agricultural journals, 109.

Wisconsin Geological Survey, aid acknowledged, 2, 4, 9, 14-16, 20 ; bulletins, 22, 24 .

Wisconsin River, topography of, 3 , 5,8 ; as a boundary, 17,42 ; erosion of, 10-11; towns on, 41, 79; lumbering on, 44, 68, 130, 132; trail to, 74 .

Wisconsiis State Agrieultural Society, organized, 104-106; reports summarized, 105-106; secretary, 108; Trunsactions, 42, 69, 114, 137.

Visconsin State Board of Immigration. See Immigration. 
Wisconsin State Horticultural Society, organized, 165.

Wisconsin State Land Office, materials in, 30 .

Wisconsin University. See College of Agriculture.

Wolf River, pinery on, 130.

Wood, J. T., Baraboo exhibitor, 118.

Wood County, topography of, 3 ; driftless area of, 10 .
Wool, production of, 97, 122-126; market for, 123. See also Sheep. "Worm" fence, illustration, 169.

Wyocena, in Columbia County, 54.

YORKSHIRE, breed of swine, 113.

Yorkshire (England), emigrants from, 49.

Zixc, mines of, 24. 

University of British Columbia Library

DUE DATE

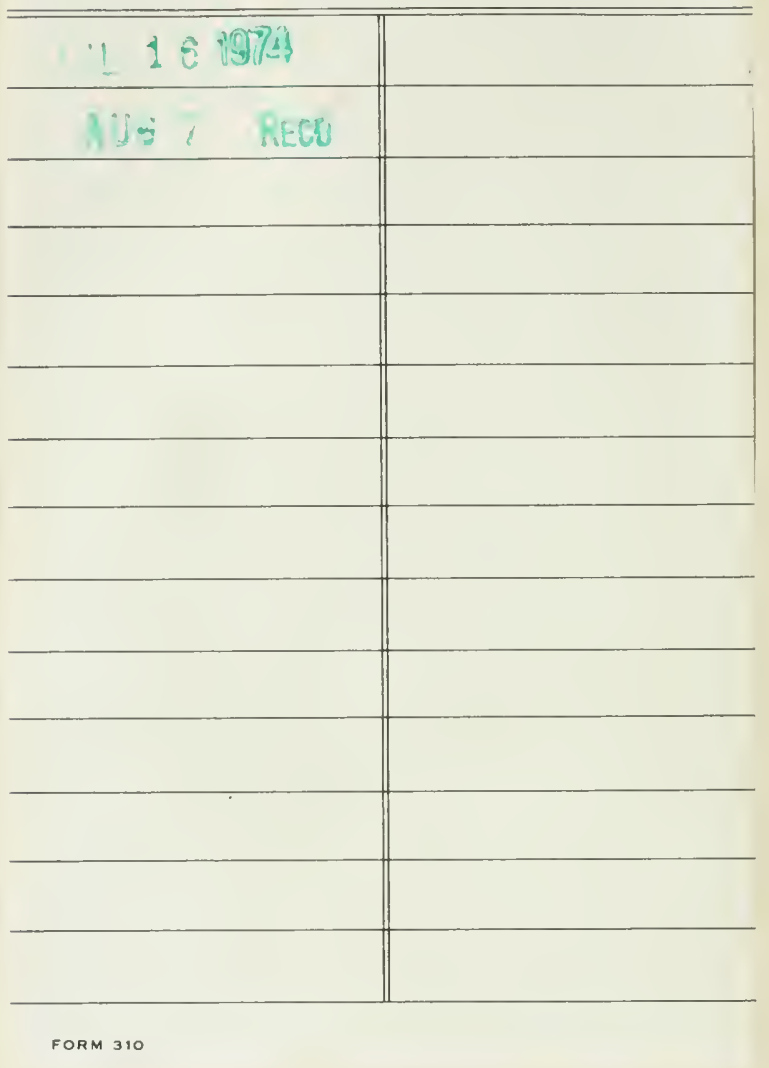




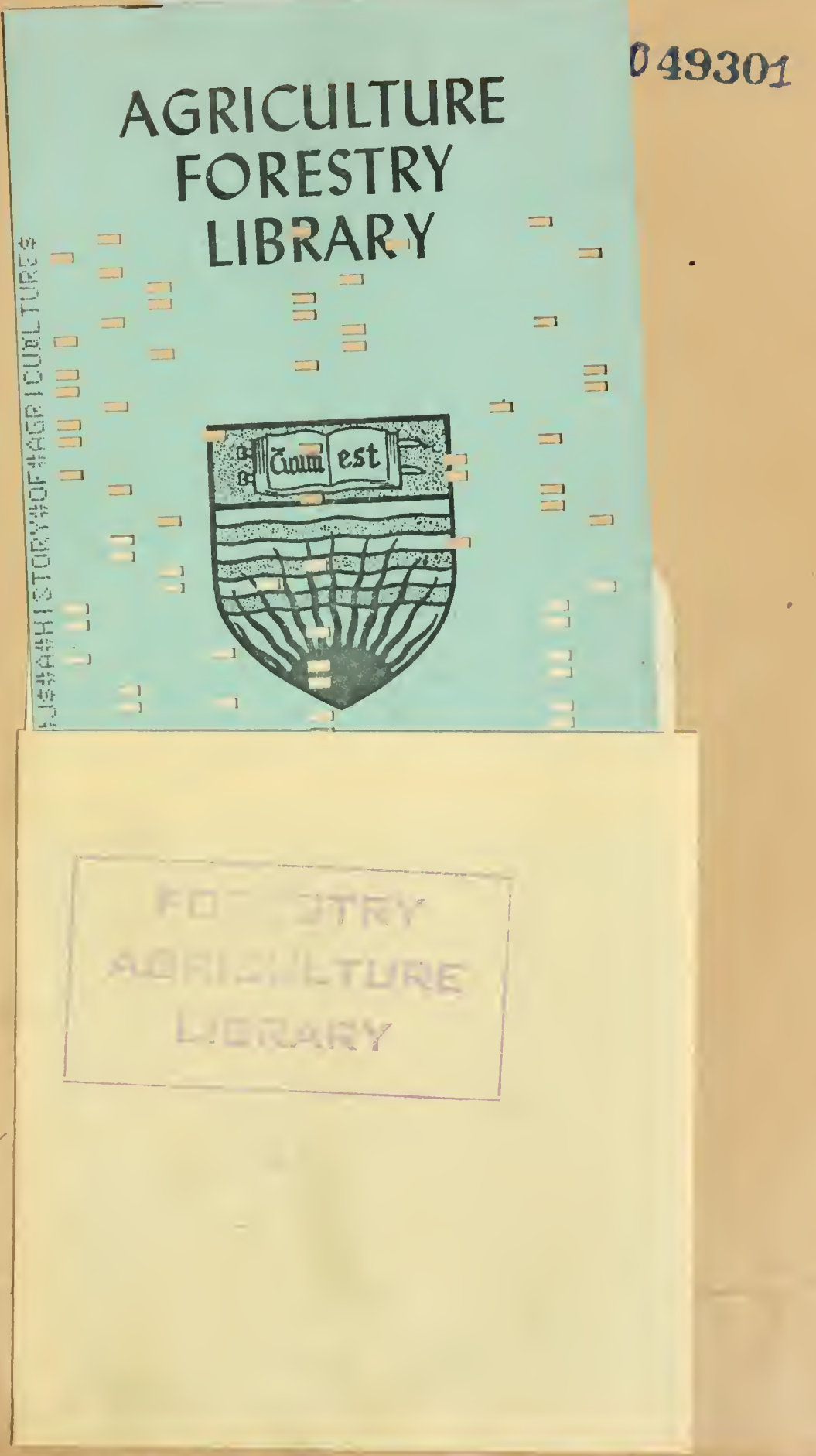


